Florida International University FIU Digital Commons

FIU Electronic Theses and Dissertations

University Graduate School

$11-8-2013$

\title{
Italianità on Tour: From the Mediterranean to Southeast Florida, 1896-1939
}

Antonietta Di Pietro

Florida International University, adipici@gmail.com

DOI: $10.25148 /$ etd.FI13120902

Follow this and additional works at: https:// digitalcommons.fiu.edu/etd

Part of the Cultural History Commons, and the European History Commons

\section{Recommended Citation}

Di Pietro, Antonietta, "Italianità on Tour: From the Mediterranean to Southeast Florida, 1896-1939" (2013). FIU Electronic Theses and Dissertations. 1003.

https://digitalcommons.fiu.edu/etd/1003

This work is brought to you for free and open access by the University Graduate School at FIU Digital Commons. It has been accepted for inclusion in FIU Electronic Theses and Dissertations by an authorized administrator of FIU Digital Commons. For more information, please contact dcc@fiu.edu. 


\title{
FLORIDA INTERNATIONAL UNIVERSITY
}

Miami, Florida

\section{ITALIANITÀ ON TOUR: FROM THE MEDITERRANEAN TO SOUTHEAST}

FLORIDA, 1896-1939

\author{
A dissertation submitted in partial fulfillment of \\ the requirements for the degree of \\ DOCTOR OF PHILOSOPHY \\ in \\ HISTORY \\ by
}

Antonietta Di Pietro

2013 
To: Dean Kenneth G. Furton

College of Arts and Sciences

This dissertation, written by Antonietta Di Pietro, and entitled Italianità on Tour: From the Mediterranean to Southeast Florida, 1896-1939, having been approved in respect to style and intellectual content, is referred to you for judgment.

We have read this dissertation and recommend that it be approved.

Pascale Becel

Gwyn Davies

Maria del Mar Logrono Narbona

Aurora Morcillo, Major Professor

Date of Defense: November 8, 2013

The dissertation of Antonietta Di Pietro is approved.

Dean Kenneth G. Furton
College of Arts and Sciences

Florida International University, 2013 


\section{DEDICATION}

In memory of my father, Domenicantonio, who told me I could.

To my husband Iser, who still does. 


\section{ACKNOWLEDGMENTS}

I will always be thankful to my friend Christine Ardalan, who made this dissertation possible by reading and editing it in its entirety and always giving me confidence. Her support and friendship have been indispensable. I am grateful to Major Professor Aurora Morcillo for her inspiration. She invited me to look for signs, symbols, and data in and out of the archives, in the streets and the ocean, the Mediterranean Caribe of this work. Thanks to the members of my dissertation committee: Pascale Becel, Gwyn Davies, and Maria del Mar Logrono Narbona, who have supported and guided me; to Noble David Cook and Joseph Patrouch, who taught me how to become a historian, and to Darden Asbury Pyron, who taught me that historians must be good writers; to Sherry Johnson, who was always kind and helpful, and to Rebecca Friedman, Jenna Gibbs, Lara Kriegel, Alex Lichtenstein, Felice Lifshitz, Kenneth James Lipartito, Brian Peterson, Bianca Premo, Mark D. Szuchman, Victor Uribe, and all my friends at FIU_-in particular, Julio Capó, Joseph Holbrook, Amanda Snyder, Paula de la Cruz Fernandez, and Hayat KassabGresham — who constantly encouraged me. Special thanks to my mother, Angela, who gave me a book on the French Revolution when I was seven, planting the seed that would yield this dissertation, and to Lilly Cangemi, whose tales on the Ventennio fascista returned to my mind many times as I was writing. My sons Walter, Ivan, and Flavio are the reason why I started this adventure, and the reason why I brought it to conclusion. Grazie, è per voi. 


\section{ABSTRACT OF THE DISSERTATION}

\section{ITALIANITÀ ON TOUR: FROM THE MEDITERRANEAN TO SOUTHEAST}

FLORIDA, 1896-1939

by

\section{Antonietta Di Pietro}

Florida International University, 2013

Miami, Florida

\section{Professor Aurora Morcillo, Major Professor}

Italianità on Tour is a cultural history of Italian consciousness in Italy and Southeast Florida from 1896 to 1939 . This dissertation examines literary works, folktales, folksongs, artworks, buildings and urban planning as imprints and cultural constructions of Italianità on both sides of the Atlantic, with a special emphasis on the transformations experienced on that journey. The real and/or imagined geo-cultural similarities between the Mediterranean and the Caribbean encouraged pioneers in Southeast Florida to conjure in their new setting an idea of Italianità, regardless of the presence of Italians in the area. Therefore, assessing Italianità, constitutes an important feature in understanding cultural constructions of identities in Miami and neighboring areas. This study, seeks to add Southeast Florida's Caribbean-Italian identity to the existing scholarship on several Italian diaspora representations, whether from a cultural ethnic perspective or from a sense of national belonging. More generally, it will show that there was no quintessential Italian national culture, but only representations of it that élites in Italy and South Florida manufactured, and on the other hand, immigrants imagined and performed upon arrival to America. 


\section{TABLE OF CONTENTS}

CHAPTER

PAGE

INTRODUCTION: THE CONCEPT OF ITALIANITÀ ............................................. 1

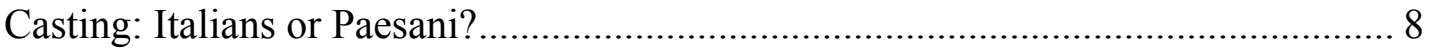

Scripting: Italianità in Italy and Southeast Florida............................................... 13

Acting. Interpreting Italianità ...................................................................... 16

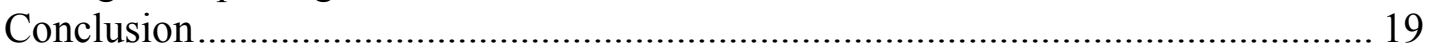

1. ITALIANITÀ: DEVELOPING A TRADEMARK FOR THE NEW ITALIAN STATE,

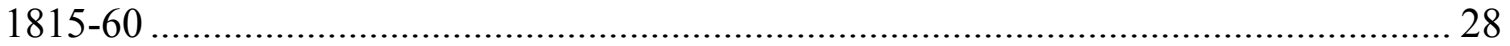

Brothers Wanted for New Production: The Literati's Voice ................................... 30

Subalterns Find Their Voices .............................................................................. 55

One Nation and Two Primedonne: Donna Turrita and Donna Lombarda ................ 62

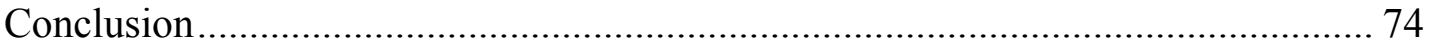

2. THE DEVELOPMENT OF THE CONCEPT OF ITALIANITÀ IN ITALY .............. 77

White but Divided, 1870-1900 ....................................................................... 82

Within the Child Lies the Fate of the Future, 1900-1915 ................................... 100

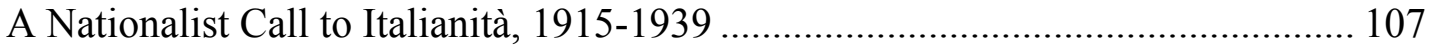

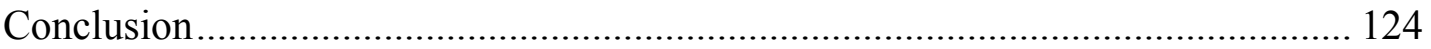

3. ITALIANS DISCOVER AMERICA AND ITALIANITÀ ....................................... 129

From a Little Village in Italy to the Little Italys in North America ....................... 132

Mapping the Italian Communities ................................................................ 146

From Italian Regional Affiliation to Italian National Loyalty ............................. 157

Miami and Its Adjoining Neighborhoods......................................................... 168

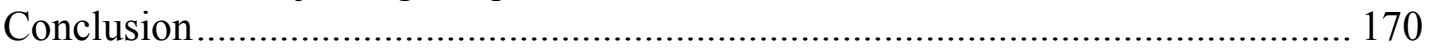

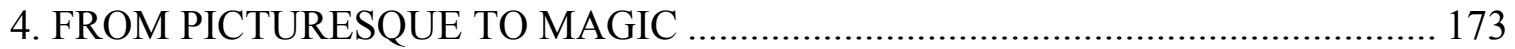

Picturesque Miami.......................................................................................... 176

The New Mediterranean-Caribbean Frontier ...................................................... 185

Caribbean Undertow and Mediterranean Identity ........................................... 200

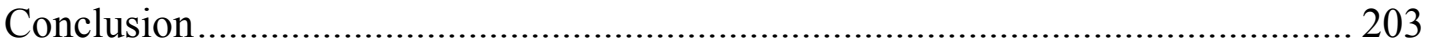

5. ITALIANS IN MIAMI AND SOUTHEAST FLORIDA: FEW BUT SIGNIFICANT

The

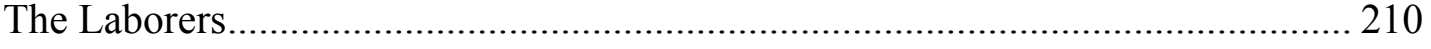

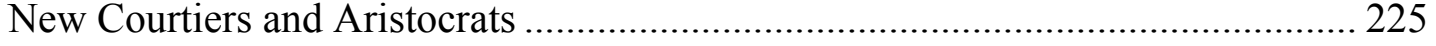

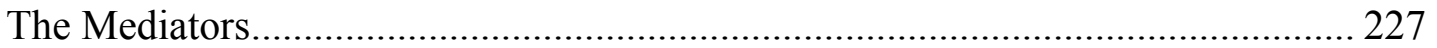

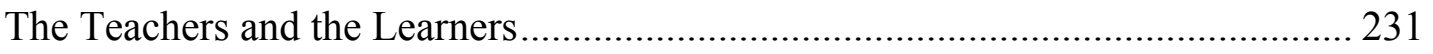

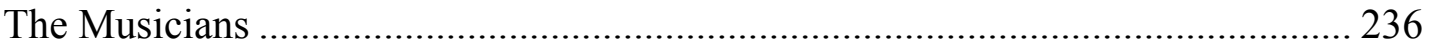

Vizcaya: a World of Artists, Stoneworkers, and Chauffeurs ............................... 237

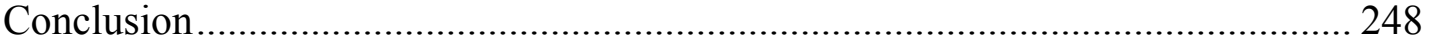




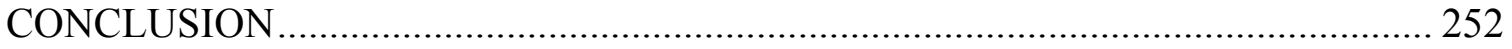

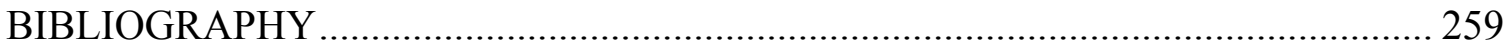

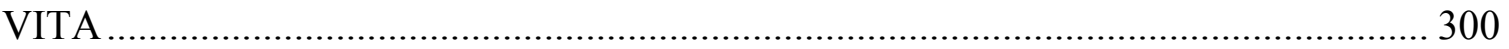




\section{LIST OF FIGURES}

\section{FIGURE}

PAGE

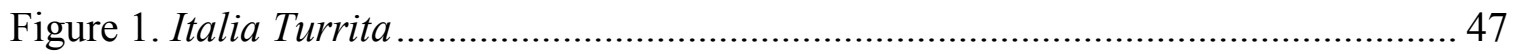

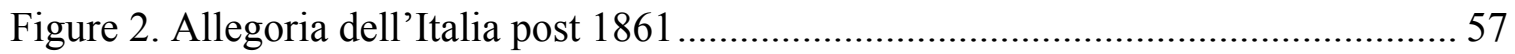

Figure 3: William Dillingham, Dictionary of Races or Peoples, page 6........................ 86

Figure 4: William Dillingham, Dictionary of Races or Peoples, page 7. ...................... 87

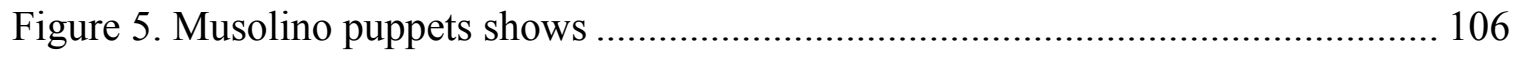

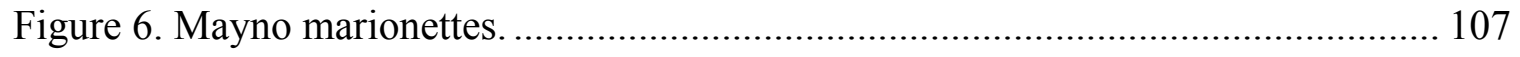

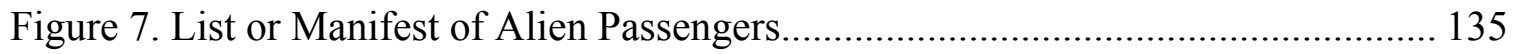

Figure 8. List or Manifest of Alien Passengers (Italy, South) .................................. 136

Figure 9. List or Manifest of Alien Passengers (Italy, North) ................................... 136

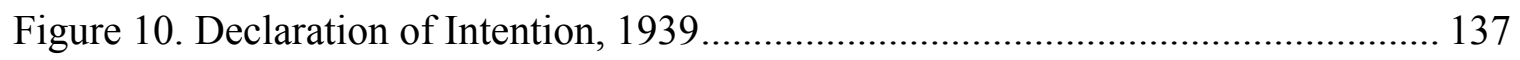

Figure 11. Organ Grinder And Monkey Collect Money........................................... 142

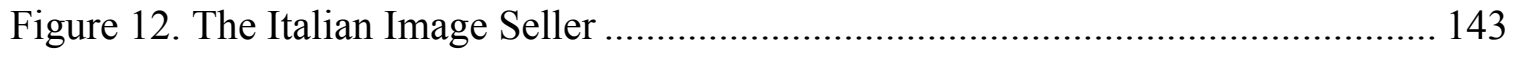

Figure 13. Italian population abroad ................................................................. 148

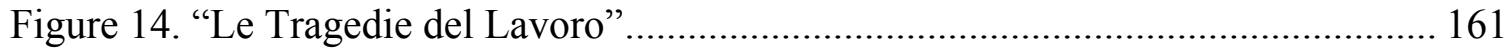

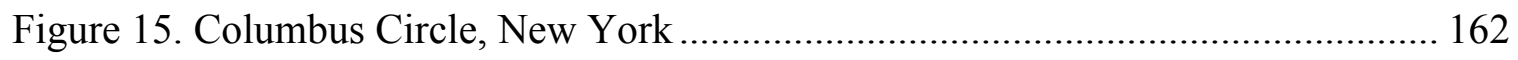

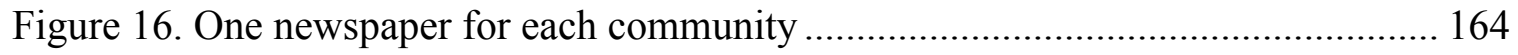

Figure 17. Arrival of the first passenger train to Miami ......................................... 176

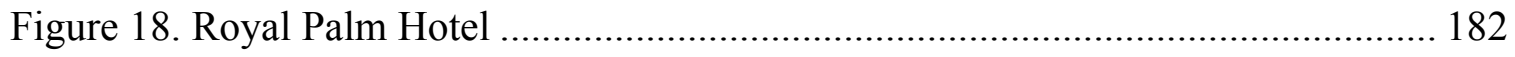

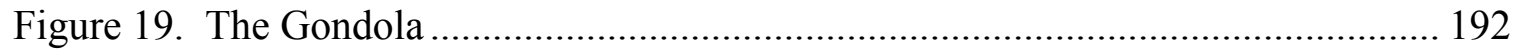

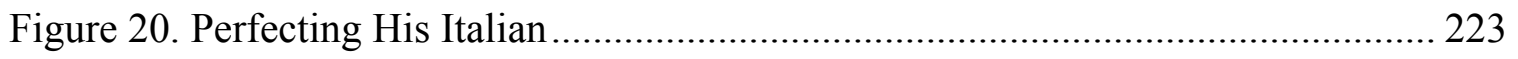

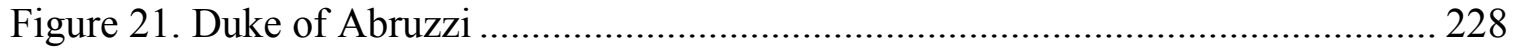




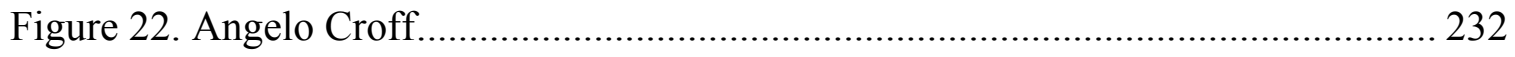

Figure 23. Katherine Hallie Elkins Hitt ................................................................... 251 


\section{ITALIANITÀ ON TOUR: FROM THE MEDITERRANEAN TO SOUTHEAST FLORIDA, 1896-1939}

\section{INTRODUCTION: THE CONCEPT OF ITALIANITÀ}

Italianità is a fluid and changeable concept that refers to the intersection of elements from Italian national identity and culture. Italianità as the result of a subjective process was, and still remains, constructed and deployed in different ways by different people in different contexts. In this dissertation, it is used to frame discussions of identity and chart cultural constructions of anything connected to Italy, its people, and language. Italianità on Tour approaches literary works, folktales, folksongs, artworks, buildings, and urban planning as imprints of Italian consciousness in order to understand constructions of Italianità in Italy and Southeast Florida from 1896 to 1939. It is, first and foremost, a cultural history of Italian consciousness and its transformation across the Atlantic. As it will be explained, there was never a quintessential Italian national culture, but only representations of it that élites manufactured, and immigrants "performed" in Italy and Southeast Florida. Exploring these processes of construction and reconstruction of Italianità in these contexts is important, because historians have largely overlooked the connection between the cultural imaginary and the actual presence of Italian immigrants and the significance of their work in Miami (founded in 1896) and adjoining neighborhoods. ${ }^{1}$ Scholars have also disregarded the many aspects of Italianità recreated

\footnotetext{
${ }^{1}$ Italians in Miami and Southeast Florida are missing from the following sources: John Higham, Strangers in the Land: Patterns of American Nativism 1860-1925 (New York: Atheneum, 1966); Nathan
} 
by non-Italian entrepreneurs and pioneers in the South Florida area and their impact on

the evolving Italian community in the region.

By 1939, on the eve of World War II, Southeast Florida had become a prime

destination for tourists and immigrants. As a result, the post-war period has attracted

significant scholarly attention. ${ }^{2}$ The coming of World War II, however, transformed

Glazer and Daniel P. Moynihan, Beyond the Melting Pot: The Negroes, Puerto Ricans, Jews, Italians and Irish of New York City (Cambridge: The MIT Press, 1963); Erik Amfitheatrof, The Children of Columbus (Boston: Little Brown and Company, 1973); Patricia Weibust, Gennaro Capobianco, and Sally Innis Gould, The Italians (World Education Project, 1976); Thomas J. Archdeacon, Becoming American (New York: Thr Free Press, 1983); Archdeacon, Becoming American; Roger Daniels, Coming to America (New York: Harper Collins Publishers, 1990); Robert Forester, The Italian Immigration of Our Times (New York: Russell and Russell, 1968); Oscar Handlin, The Uprooted (Boston: Little Brown and Co., 1973); William A. Heap, The Story of Ellis Island (New Jersey: Prentice Hall, 1959); Salvatore La Gumina, The Immigrant Speaks (New York: The Center for Migration Studies, 1981); Stanley Lieberson and Mary C. Walters, From Many Strands (New York: Russel Sage Foundation, 1988); Gary Null and Carl Stone, The ItalianAmericans (Harrisburg: Stagpole, 1976); Jacob Riis, How the Other Half Lives: Studies Among the Tenements of New York (New York: Hill and Wang, 1957); Ronald Takaki, A Larger Memory (Boston: Little Brown and Co., 1998); Virginia Yans-McLaughlin and Marjorie Lightman, Ellis Island and the Peopling of America (New York: The New York Press, 1990); James Davidson and Mark Hamilton Lytle, After the Fact: The Art of Historical Detection (New York: Alfred A. Knopf, 1986); Michael Musmanno, The Italians in America (New York: Doubleday and Co., 1965); Joan Morrison and Charlotte Fox Zabusky, The Immigration Experience in the Words of Those Who Lived It (New York: E. P. Dutton, 1980); Weibust, Capobianco, and Innis Gould, The Italians; Gary Ross Mormino and George E. Pozzetta, The Immigrant World of Ybor City: Italians and Their Latin Neighbors in Tampa, 1885-1985 (Urbana: University of Illinois Press, 1987).

${ }^{2}$ Alejandro Portes and Stepick Alex, City on the Edge: The Transformation of Miami (Berkeley: University of California Press, 1993); Sheila L. Croucher, Imagining Miami: Ethnic Politics in a Postmodern World (Charlottesville: University of Virginia Press, 1997); Gary Ross Mormino and Raymond Arsenault, Land of Sunshine, State of Dreams: A Social History of Modern Florida (Gainesville: University Press of Florida, 2008); Guillermo Grenier and Stepick Alex, Miami Now! Immigration, Ethnicity, and Social Change (Gainesville: University Press of Florida, 1992); Juan Gonzalez, Harvest of Empire (New York: The Penguin Group, 2000); Raymond A. Mohl, "Florida's Changing Demography: Population Growth, Urbanization, and Latinization," Environmental and Urban Issues 17 (1990): 22-30; Mohl, "Florida's Changing Demography"; Raymond Arsenault and Gary R. Mormino, "From Dixie to Dreamland: Demographic and Cultural Change in Florida, 1880-1980," in Shades of the Sunbelt: Essays on Ethnicity, Race, and the Urban South, Randall M. Miller and George E. Pozzetta (New York: Greenwood Press, 1988), 161-91.Raymond Arsenault, Land of Sunshine, State of Dreams: A Social History of Modern Florida (Gainesville: University Press of Florida, 2008); Guillermo Grenier and Stepick Alex, Miami Now! Immigration, Ethnicity, and Social Change (Gainesville: University Press of Florida, 1992); Juan Gonzalez, Harvest of Empire (New York: The Penguin Group, 2000); Raymond A. Mohl, "Florida's Changing Demography: Population Growth, Urbanization, and Latinization," Environmental and Urban Issues 17 (1990): 22-30; Mohl, "Florida's Changing Demography"; Raymond Arsenault and 
Florida, ending a period of a somewhat artificial cultural experimentation and heralding more "natural" dynamics of interaction. Therefore, the eve of the War provides the upper terminus for this study.

While Italianità on Tour is not intended as a systematic study of Italian immigration and of "Little Italys" within the United States, exploring the development of Italian identity within Italian history, particularly in reference to the Italian immigrant communities in New York and Philadelphia, will be essential to contextualize the formation of Italianità in Southeast Florida. ${ }^{3}$ In large part because of its Southeast coast location and its protrusion into the Caribbean Sea (which in some ways mirrored Italy's into the Mediterranean), late nineteenth and early twentieth century pioneers imagined

Gary R. Mormino, "From Dixie to Dreamland: Demographic and Cultural Change in Florida, 1880-1980," in Shades of the Sunbelt: Essays on Ethnicity, Race, and the Urban South, Randall M. Miller and George E. Pozzetta (New York: Greenwood Press, 1988), 161-91.

${ }^{3}$ For more on Italian immigration see John Higham, Strangers in the Land: Patterns of American Nativism 1860-1925 (New York: Atheneum, 1966); Nathan Glazer and Daniel P. Moynihan, Beyond the Melting Pot: The Negroes, Puerto Ricans, Jews, Italians and Irish of New York City (Cambridge: The MIT Press, 1963); Erik Amfitheatrof, The Children of Columbus (Boston: Little Brown and Company, 1973); Patricia Weibust, Gennaro Capobianco, and Sally Innis Gould, The Italians (World Education Project, 1976); Thomas J. Archdeacon, Becoming American (New York: The Free Press, 1983); Archdeacon, Becoming American; Roger Daniels, Coming to America (New York: Harper Collins Publishers, 1990); Robert Forester, The Italian Immigration of Our Times (New York: Russell and Russell, 1968); Oscar Handlin, The Uprooted (Boston: Little Brown and Co., 1973); William A. Heap, The Story of Ellis Island (New Jersey: Prentice Hall, 1959); Salvatore La Gumina, The Immigrant Speaks (New York: The Center for Migration Studies, 1981); Stanley Lieberson and Mary C. Walters, From Many Strands (New York: Russel Sage Foundation, 1988); Gary Null and Carl Stone, The Italian-Americans (Harrisburg: Stagpole, 1976); Jacob Riis, How the Other Half Lives: Studies Among the Tenements of New York (New York: Hill and Wang, 1957); Ronald Takaki, A Larger Memory (Boston: Little Brown and Co., 1998); Virginia YansMcLaughlin and Marjorie Lightman, Ellis Island and the Peopling of America (New York: The New York Press, 1990); James Davidson and Mark Hamilton Lytle, After the Fact: The Art of Historical Detection (New York: Alfred A. Knopf, 1986); Michael Musmanno, The Italians in America (New York: Doubleday and Co., 1965); Joan Morrison and Charlotte Fox Zabusky, The Immigration Experience in the Words of Those Who Lived It (New York: E. P. Dutton, 1980); Weibust, Capobianco, and Innis Gould, The Italians; Gary Ross Mormino and George E. Pozzetta, The Immigrant World of Ybor City: Italians and Their Latin Neighbors in Tampa, 1885-1985 (Urbana: University of Illinois Press, 1987). 
Southeast Florida as "another" Italy, conjuring a hybrid, and at times ambiguous idea of

Italianità that included, among other things, generic Mediterranean-Spanish, Greek, and

Northern-African—elements. ${ }^{4}$ While further increasing the difficulty of assessing

Italianità and its variations, the amalgam of Mediterranean tropes, however, is crucial to

understanding cultural constructions in Miami and neighboring areas. This work,

therefore, seeks to add Southeast Florida's Caribbean-Italian/Mediterranean identity to

the existing scholarship on Italian ethnicity, culture, diaspora, citizenship, nation-ness and

representation. $^{5}$

Many scholars have attempted to explain Italian character and identity. ${ }^{6}$ In her

analysis of character discourse in modern Italian political culture, historian Silvana

${ }^{4}$ Lezama José Lima, Selections, <ed.> Livon-Grosman, Ernesto (Berkley and California: University of California Berkley, 2005); Thomas Henry Huxley, "On the Geographical Distribution of the Chief Modifications of Mankind," Journal of the Ethnological Society of London III (1870); Benitéz Antonio Rojo, "Alejo Carpentier: Between Here and Over There," Caribbean Studies 27, no. 3/4 (1994): 183-95; Marco Katz, "Not India, in Which Alejo Carpentier and Zora Neale Hurston Finally Discover America," Bibliothèque et Archives Canada Direction du Partrimoine de l'édition (2011): 1344Edmonton: University of Alberta, 2011.

${ }^{5}$ Ilvo Diamanti, "L’Italia è la Nostra Famiglia," Limes 2 (2009); Jacques Le Goff, "L’Italia Fuori d'Italia," in vol. II, L'Italia Nello Specchio del Medioevo, Ruggiero Romano and Corrado Vivanti, Storia d'Italia (Torino: Einaudi, 1974); Walter Barberis, Il Bisogno di Patria (Torino: Einaudi, 2010); Remo Bodei, Il Noi Diviso. Ethos e Idee Dell'Italia Repubblicana (Torino: Einaudi, 1998); John Dickie, "The Notion of Italy," in The Cambridge Companion to Modern Italian Culture, Baranski Zygmunt and Rebecca West (Cambridge: Cambridge University Press, 2001); Giorgio Agamben, Categorie Italiane. Studi di Poetica e di Letteratura (Roma-Bari: Laterza, 2010); Alberto Asor Rosa, Genus Italicum. Saggi Sull'identità Letteraria Italiana Nel Corso del Tempo (Torino: Einaudi, 1997); G. Bollati, "I Caratteri Originali," Storia d'Italia 1 (1972)L'Italiano, vol. 1 of L'Italiano. Il Carattere Nazionale Come Storia e Come Invenzione; Silvana Patriarca, Italian Vices: Nation and Character from the Risorgimento to the Republic (Cambridge: Cambridge University Press, 2010).

${ }^{6}$ Didier Musiedlak, "Construction Politique et Identité Nationale," in L'Italie, une Nation en Suspens, Ilvo Diamanti, et al. (Bruxelles: Editions Complexe, 1995); Giuseppe Galasso, L'Italia s'è Desta, Identità Storica e Unità Nazionale Dal Risorgimento Alla Repubblica (Firenze: Le Monnier, 2002); Ernesto Galli della Loggia, L'Identità Italiana (Bologna: Il Mulino, 1998); Mario Isneghi, "Gli Italiani in Guerra. Conflitti, Identità, Memorie Dal Risorgimento Ai Nostri Giorni," in Gli Italiani in Guerra. Conflitti, Identità, Memorie Dal Risorgimento Ai Nostri Giorni (Torino: Utet, 2009); Emilio Gentile, Né Stato Né 
Patriarca evaluated Italian virtues and vices and their interaction. She defined the notion of character not as cultural/ethnic uniqueness, but as a set of predispositions "that translate into the public and political attitudes of a people". ${ }^{7}$ In a similar vein, philosopher Enrico Guglielminetti argued that Italians display a natural split identity, which explains the coexistence of passions and partisanship, patriotism and antipatriotic feelings. ${ }^{8}$ In March 2011, on the occasion of the hundred and fiftieth anniversary of Italy's unification, an Italian journal (Limes) attempted to address the matter in detail. ${ }^{9}$ The commemoration had prompted a survey of Italians. ${ }^{10}$ An analysis of their responses to the question of what it meant to be Italian revealed that most were proud of the idea albeit demonstrating some irony. The headline revealed the paradox that many Italians associated with their national

Nazione. Italiani Senza Meta (Bari: Laterza); Silvana Patriarca, Italian Vices: Nation and Character from the Risorgimento to the Republic (Cambridge: Cambridge University Press, 2010).

${ }^{7}$ Silvana Patriarca, Italian Vices: Nation and Character from the Risorgimento to the Republic (Cambridge: Cambridge University Press, 2010), 11. (2011): 141 .

${ }^{8}$ Enrico Guglielminetti, “Prefisso Paese: Re-. Alla Ricerca Dell'Italianità,” Spaziofilosofico 2

${ }^{9}$ The Kingdom of Italy (1861-1946) was born in 1861, following the House of Savoy's 1859 victory over Austria, which ended Austrian occupation of Lombardy and of other territories in the peninsula.

${ }^{10}$ Some of the questions were: "Which of the following characters is more suitable to distinguish Italians from other peoples?" [Possible answers: attachment to the family; the art of getting by; Catholic tradition; creativity; civic sense and confidence in the state; etc.]; "Which of the following makes you proud to be Italian?" [Possible answers: cultural heritage; fashion and design; music; sport; politics and politicians; food; etc.]; "Which of the following events have left a positive mark on the Italian national history?'[Possible answers: Italian Constitution; Risorgimento; World War I; World War II; Fascism; Resistance; Terrorism; etc.]; "With which of the following opinions are you in agreement?" [Possible answers: the South is a burden to the country's development; Northern and Southern Italians are too different, and Italy should be divided; the South is selfish; etc.]. Luigi Ceccarini and Ilvo Diamanti, "Italiani, malgrado tutto," Limes rivista italiana di geopolitica 2 (2011), 27-36. 
identity: "Despite everything... we are Italians, after all." ${ }^{11}$ After 150 years, the report reflected an ongoing urgency to verify the idea of "being Italian." Yet, as many have pointed out, this process of construction cannot be easily explained. ${ }^{12}$ By attempting to classify and categorize identity, the article merely reduced Italianità to rigid sets and statistics, implying that Italians suffered significant hardships to maintain their Italianità but failing to identify exactly what this idea entailed or, most importantly, to claim for themselves the notion of Italianità itself.

During the years that followed the Italian Risorgimento, Italy was too deeply divided socially, politically, and geographically for a single and representative culture to emerge and be exported as a "national” identity. ${ }^{13}$ Since Italy's unification in 1861 ,

\footnotetext{
${ }^{11}$ Emphasis added. Translated from the Italian text: malgrado tutto. Luigi Ceccarini and Ilvo Diamanti, "Italiani, malgrado tutto," Limes rivista italiana di geopolitica 2 (2011).
}

${ }^{12}$ Didier Musiedlak, "Construction Politique et Identité Nationale," in L'Italie, une Nation en Suspens, Ilvo Diamanti, et al. (Bruxelles: Editions Complexe, 1995); Giuseppe Galasso, L'Italia s'è Desta, Identità Storica e Unità Nazionale Dal Risorgimento Alla Repubblica (Firenze: Le Monnier, 2002); Ernesto Galli della Loggia, L'Identità Italiana (Bologna: Il Mulino, 1998); Mario Isneghi, "Gli Italiani in Guerra. Conflitti, Identità, Memorie Dal Risorgimento Ai Nostri Giorni," in Gli Italiani in Guerra. Conflitti, Identità, Memorie Dal Risorgimento Ai Nostri Giorni (Torino: Utet, 2009); Emilio Gentile, Né Stato Né Nazione. Italiani Senza Meta (Bari: Laterza); Silvana Patriarca, Italian Vices: Nation and Character from the Risorgimento to the Republic (Cambridge: Cambridge University Press, 2010).

${ }^{13}$ The Italian Risorgimento was a period of political and social tumults and claims to independence from foreign influence in Italy. It began after the 1815 Congress of Vienna, which sanctioned the end of Napoleonic rule in the peninsula, and was completed by the proclamation of the Italian State in 1861 and the 1870 capture of Rome from the Pope. The situation in Italy after the Congress of Vienna was that of a country divided into various states and controlled, directly or indirectly, from Austria in the north, the Pope in the center and the Bourbons in the south. Members of the Italian movement for independence looked at Victor Emmanuel II (1820-1878), king of Savoy and Piedmont, as the only one able to unite the country. Indeed, Victor Emmanuel and his minister Camillo Cavour (1810-61) were interested in implementing an international strategy to consolidate Piedmont's position in Europe. They opened negotiations with Giuseppe Garibaldi (1807-1882), who was, along with Giuseppe Mazzini (1805-1872), one of the leaders of the Italian revolutions for independence in the 1840s. Garibaldi agreed to cooperate with Cavour in order to reach the goal of Italy's unification. After a series of independence wars and revolts, in 1861 the unification of Italy was then proclaimed, even if it still lacked Lazio (controlled by Pope Pius IX, b.1792-1878), Veneto and Trentino (under Austrian authority). 
Italian literati had yearned for the construction of an Italian character-Italianità-shared by an expansive community that also included 'low-rank' persons or groups of people. Former aristocrats, turned into government functionaries, politicians, and scientists, recognized that Italy needed both an élite ruling class and subalterns in order to remain on, let alone rise within, the national and international public scene. ${ }^{14}$ They saw members of the lower classes as necessary partakers in the nation-building project, and called on them to contribute to the forging of a common history and identity.

The issue of Italianità, however, was not so crucial for the majority of these people. Exploring and examining folksongs and folktales helps to understand how the farmers' and peasants' understanding of Italian political events and identity were filtered through local particularities. Variations of local and regional histories complicated scholars' discussions and their qualms as to what made Italianità and their ideas on how to "become Italian." Between 1876 and 1915, more than four million people left Italy for the United States, bringing with them the complex relationship between the intellectuals' imagined national character and their regional individualities. ${ }^{15}$ Many faced the idea of

\footnotetext{
${ }^{14}$ Since the term 'subaltern' frequently recurs in this work, few words to explain the way I use it are necessary. I borrow the term "subaltern" from political theorist Antonio Gramsci (1891-1937) to delineate the majority of the population held in subordinate position by the temporal and spiritual ruling classes, by foreign invaders, latifundists, the Liberal élite, and Fascists - in chronological order. For more on the concept of "subaltern", see El Habib Louai, "Retracing the Concept of the Subaltern from Gramsci to Spivak: Historical Developments and New Applications," African Journal of History and Culture 4, no. 1 (2012): 4-8; Antonio Gramsci, I quaderni: letteratura e vita nazionale, I quaderni dal carcere (Roma: Editori Riuniti, 1996); Antonio Gramsci, Selections from the Prison Notebooks, <eds> Hoare, Q., Nowell Smith, G. (New York: International Publishers, 1995).

${ }^{15}$ According to scholars Ugo Imperatori, Francesco Balletta, and Gianfausto Rosoli, the exact number was 4, 351,635. See Ugo E. Imperatori, Dizionario di Italiani all'estero: Dal XIII secolo sino a oggi (Genoa: L'Emigrante, 1956); Francesco Balletta, Un secolo di emigrazione italiana, 1876-1976,
} 
being Italian for the first time in the United States, when they encountered and were forced to interact with local cultural representations of Italianità as perceived by outsiders in a foreign land. Italy's emigrants had never been Italian in Italy; in the United States, they learned to be Italian when necessary for them to survive let alone prosper. In the years 1896-1939, a unified Italianità was primarily an invented concept for Italy's intellectuals and a recreated ideal or fantasy of Italian culture for Americans. For Italy's emigrants, on the other hand, Italianità became a series of social acts performed to respond to the host society's demands.

\section{Casting: Italians or Paesani? ${ }^{16}$}

The theoretical framework for this dissertation is drawn from the rich literature on the subject of Italianità and national identity formation, which includes not only histories but also studies in anthropology and cultural history. The contributions of the Manchester School, with their emphasis on detailed case studies and dynamics of social interaction, offer an ideal starting point. From the 1940s to the 1970s, Max Gluckman (1911-1975) and his students and followers wrote on urbanization and colonialism and how these processes related to the birth of nation-states in post-colonial Africa. ${ }^{17}$ Their

Gianfausto Rosoli (Rome: Centro studi emigrazione, 1978), quoted in Donna Gabaccia, Italy's Many Diasporas (Seattle: University of Washington Press, 2000), 4.

${ }^{16}$ Paesani as villagers, as opposed to citizens of the nation.

${ }^{17}$ See Max Gluckman, Rituals of rebellion in South-East Africa (Manchester: The University of Manchester Press, 1954); Abner Cohen (1921-2001),Custom and Politics in Urban Africa: A Study of Hausa Migrants in Yoruba Towns (London: Routledge \& Kegan Paul, 1969); Arnold L. Epstein ( $1924-$ 99), Ethos and Identity: Three Studies in Ethnicity (London: Tavistock Publications, 1978); Elizabeth Colson (1917-), The Social Organization of the Gwembe Tonga (Manchester: The University of Manchester Press, 1960); J. Clyde Mitchell (1918-1995), The Yao Village: A Study in the Social Structure 
preoccupation with the changes brought about by colonist-colonized relationships formalized concepts such as context, boundary maintenance, and 'ethnic groups' in place of 'tribes'. Proponents of this approach focused on the social relations between groups, contradictions and conflicts, and, in particular, cultural outcomes: accusations, rites, rituals, and mediation processes within the groups and between groups and outsiders.

These dialectical clusters - colonists and colonized (or insiders and outsiders) in Gluckman's work - offer useful parallels for considering the interactions at multiple levels between American receivers and Italian immigrants, Northern/Southern Italians, rural/urban groups, and upper-/lower-class subjects. They all inhabited spaces the physical borders and symbolic boundaries of which were continuously renegotiated as a result of social interactions. Italian emigrants were outsiders in the United States while among them, those from the Southern regions of Italy also carried an added political and social outsiders status. Italian conservatives, liberals, Catholics, and literates alikemostly Northerners - used a string of epithets to voice their perception of the Southern Italian other. They called them "Africans", "Neapolitans", or "Orientals." ${ }^{\text {"18 }}$ Carlo Lozzi (1829-1915), a member of the Italian intellectual élite, noted that Italian Southerners

of a Nyasaland Tribe (Manchester: The University of Manchester Press, 1956); Bruce Kapferer (1940-), Strategy and Transaction in an African Factory: African Workers and Indian Management in a Zambian Town (Manchester: The University of Manchester Press, 1972); Victor Turner (1920-83), The Forest of Symbols: Aspects of Ndembu Ritual (New York: Cornell University Press, 1967). See also: Edmund Leach(1910-89), Culture and Communication: The Logic by Which Symbols are Connected (Cambridge: Cambridge University Press, 1976); Frederik Barth(1928- ), and Richard B. Werbner(1938- ), Ritual Passage, Sacred Journey: Process and Organization of Religious Movement (Smithsonian Institution, 1989).

${ }^{18}$ Carlo Lozzi, Dell'ozio in Italia (Turin: Unione Tipografico-editrice, 1870-1871), 63-67. 
resembled the most "decayed" human beings and "were even worse than the dirtier Orientals."19 This derogatory categorization echoes colonist-colonized power relations within the European context that preceded the departure to the new world. "Southerner" had become a disparaging categorization since Georg Hegel's ideas on history began circulating in Europe in the $1830 \mathrm{~s} .{ }^{20}$ Hegel argued for the centrality of Europe in world history and civilization. ${ }^{21}$ But what Europe? He proposed that, since the Mediterranean Sea united the three constituent parts of the Old World (Europe, Africa, and Asia), it "was the axis of universal history." 22 At the same time, he was quick to clarify that it was the northern regions of Europe that played the central role. ${ }^{23}$ It did not take long for academics to reflect on Southern people and Southern European countries (Italy, Spain,

${ }^{19}$ Carlo Lozzi, Dell'ozio in Italia (Turin: Unione Tipografico-editrice, 1870-1871), 63-67.

${ }^{20}$ Hegel's Lectures on Philosophy of History was published posthumously and for the first time in 1837. See Georg Wilhelm Friedrich Hegel, Lectures on the Philosophy of History (London: George Bell and Sons, 1902 [first ed. 1837]).

${ }^{21}$ Georg Wilhelm Friedrich Hegel, Lectures on the Philosophy of History (London: George Bell and Sons, 1902 [first ed. 1837]), 135.

${ }^{22}$ I will explore this concept in my discussion on Caribbean-Italianità in Chapter 3. For more on Hegel's reflection of universal history see Georg Wilhelm Friedrich Hegel, Lectures on the Philosophy of History (London: George Bell and Sons, 1902 [first ed. 1837]), 143-4. Philosopher Enrique Dussel writes that Hegel was not interested in the New World of the Americas as this was still "in formation." See http://enriquedussel.com/DVD\%20Obras\%20Enrique\%20Dussel/Textos/23-1/03chapter1pp17-26.pdf retrieved 07/21/2013.

${ }^{23}$ My emphasis. 
and Greece) in orientalized terms: they became part of a Mediterranean space in their imagination rich with the values that only the Northern European peoples could inherit. ${ }^{24}$

At the dawn of Italy's nationhood in the late 1800s, the Italian leading class on the one hand, and farmers and peasants on the other, had traced a divide between their worlds that allowed only unequal exchanges. Until then, the majority of the Italian peoples, mostly illiterate peasants, had placed themselves within the rural geographic and social space of their villages, and few Southerners identified with the more urbanized and advanced realities of some Northern regions. ${ }^{25}$ Anthropologist Anthony P. Cohen proposes that the production of conceptual boundaries to mark and protect social identities is necessary for socialization and survival. He argues that individuals create demarcations through the furthest point of their travel. ${ }^{26}$

The fourteen million immigrants — mostly from the South — who departed from Italy between 1876 and 1914, expanded their horizons to localities beyond the social boundaries of their villages and the political frontier of the Italian state. ${ }^{27}$ The political

\footnotetext{
${ }^{24}$ Orientalism is used in this work to convey intellectual attitudes that fabricate assumptions about people and cultures according to pre-concepts and stereotypes. It derives its name from Edward Said, Orientalism (New York: Pantheon Books, 1978). For "oriental" Spain, see Aurora Morcillo, "The Orient Within. Women 'in-between' under Francoism," in Women in the Middle East and North Africa: Agents of Change, Fatima Sadiqi and Moha Ennaji (New York: Routledge, 2011).

${ }^{25}$ This sense of identity and belonging to the villages and towns' geographic and social spaces is called campanilismo.It derives from "campanile", bell tower, the tallest building normally erected at the center of the village or town.

${ }^{26}$ Anthony P. Cohen, Signifying Identities: Anthropological Perspectives on Boundaries and Contested Values (London and New York: Routledge, 2000), 7.

${ }^{27}$ Ugo E. Imperatori, Dizionario di Italiani all'estero: Dal XIII secolo sino a oggi (Genoa: L’Emigrante, 1956); Francesco Balletta, Un secolo di emigrazione italiana, 1876-1976, Gianfausto Rosoli
} 
and economic hardship of their time forced these people to look for different horizons and to create new boundaries. Initially, some of them moved within Italy. Historian Stefania Torre compared data on emigration from North, Central, and South Italy with the number of births and deaths of the people who continued to reside in those areas in the period 1876-1900. She noticed how the population in North Italy grew even though the percentage of Northern Italian emigrants was higher than the number of births, and argued that the increase was the result of internal migration from South and Central Italy. ${ }^{28}$ More than one-third of those who left Italy over this time reached the United States. $^{29}$ In those new places-whether in Italy, Europe, or the Americas-Italians strived to attain better living conditions and establish new networks of personal relationships. Their new realities contributed significantly to their sense of individual and collective identities and socialization.

In Southeast Florida, as elsewhere, the behavior of these immigrant groups and the expectations of their host societies left profound marks, for instance on the urban landscape of Miami. As mentioned above, the focus of this dissertation is to explore the

(Rome: Centro studi emigrazione, 1978), quoted in Donna Gabaccia, Italy's Many Diasporas (Seattle: University of Washington Press, 2000), 4.

${ }^{28}$ Stefania Torre, 'L'Emigrazione in Italia dal 1871 al 1911 e il Mezzogiorno," in Nord e Sud a 150 Anni dall'Unità d'Italia, vol. Numero speciale, Quaderni SVIMEZ (SVIMEZ Associazione per lo sviluppo dell'industria nel Mezzogiorno, 2012), 566-7; 150 Anni di Statistiche Italiane: Nord e Sud, 18612011, SVIMEZ (Bologna: Il Mulino, 2011).

${ }^{29}$ Ugo E. Imperatori, Dizionario di Italiani all'estero: Dal XIII secolo sino a oggi (Genoa: L'Emigrante, 1956); Francesco Balletta, Un secolo di emigrazione italiana, 1876-1976, Gianfausto Rosoli (Rome: Centro studi emigrazione, 1978), quoted in Donna Gabaccia, Italy's Many Diasporas (Seattle: University of Washington Press, 2000), 4. 
expansion of Italianità in Southeast Florida and understand how Italian identity became equated to a new "brand" denoting more a Southern European culture within the Mediterranean cultures in general, and the cradle of western values. These conceptions had little to do with the treatment of the individuals coming from that region and more with an imagined community coined over time by intellectuals in Italy and rich developers in the United States.

\section{Scripting: Italianità in Italy and Southeast Florida}

Those holding authority in Italy and Southeast Florida certified their supremacy and influenced the actions of individuals and social groups through the invention of new texts. ${ }^{30}$ In Italy, they produced brigands' legends. As late as the $1950 \mathrm{~s}$, the idea of a “brigands' war" in South Italy, which began as a theatrical invention during the closing decades of the nineteenth century, was systematically dismantled by a new revisionist historical perspective. Revisionism was the first step towards a new Catholic reading of Italian history. ${ }^{31}$ This approach aimed for a reevaluation of the roles of Pius IX (1792-

${ }^{30}$ Foucault described discourse as "an entity of sequences, of signs, in that they are enouncements (énoncés)", or abstract construct that transforms signs into vehicles of specific, repeatable relations among objects, subjects, and statements. For Michel Foucault, a statement is the material element in a discursive formation, a concept extensively treated in his work. Foucault wrote "whenever, between objects, types of statement, concepts, or thematic choices, one can define regularity (an order . ..), we will say, for the sake of convenience, that we are dealing with a discursive formation." The way in which collections of texts (statements) are assembled and organized are "reflexive categories, principles of classification, normative rules, institutionalized types that deserve to be analyzed" in order to understand the fabricator of such statements. See Michel Foucault, The Archaeology of Knowledge, trans. by Sheridan Smith, A.M., (New York: Pantheon, 1972), 22, 38; "The masked philosopher," in Michael Foucault: Politics, Philosophy, Culture. Interviews and Other Writings, 1977-1984, Kritzman, L.D. (Ed.), trans. by Sheridan, A., (New York: Routledge, 1988).

${ }^{31}$ In the post-World War II years, antimonarchical feelings were common. The first Prime Minister of the new Italian Republic was Alcide De Gasperi (1881-1954), an Italian Northerner from 
1878 ) and the debasement of the monarchy's role in Italy's process of unification. ${ }^{32}$

Historian and author Carlo Alianello (1901-1981), a staunch Catholic, was one of the major Italian revisionists of the Risorgimento and unification in the 1950s. He presented those in Italy who rebelled against King Victor Emmanuel II of Savoy (1820-1878) not as brigands but as workers and peasants exposed to deprivation by Piedmont's authority. ${ }^{33}$

Revisionists described Risorgimento as a colonizing enterprise, with the House of Savoy seeking to recover and annex lands in the Italian Peninsula controlled by foreign governments. This reading explained the élite's fake pretension of a war of defense against the enemies of unification, the brigands. The official invention of the brigands' myth served to cover internal rebellions against the new order, a rule that differed little

Trentino Alto Adige. He was a Christian Democrat. The Christian Democratic Party controlled the Italian government from 1945 to 1992, with few sporadic interruptions. Revisionism came about in those years.

${ }^{32}$ In the first years of Risorgimento, Pius IX had liberal sympathies and was favorable to the establishment of a constitutional monarchy in Italy. A few years later, in the 1840s, he opposed the wars to Catholic Austria, claiming to be above national interests. His position caused resentment among the Italian revolutionaries, and eventually led him to exile. During his exile, his liberal ideas transformed into reactionary positions. In 1866, Victor Emmanuel II conquered the Papal territories, with the exception of Latium and Rome, which were annexed in 1870. With the encyclical Ubi Nos, Pius IX declared he affirmed that he retained his rights and claims to the territories annexed to Italy and rejected the King's authority.

${ }^{33}$ Turin, in Piedmont, was the capital and seat of the newly formed government of the Kingdom of Italy. Carlo Alianello, L'alfiere (Milan: BUR Rizzoli, 2011 [1942]); L'eredità della priora (Venosa: Osanna Edizioni, 1993 [1963]); La conquista del sud (Sant'Arcangelo di Romagna: Rusconi Libri, 1972); Michele Topa, Cosi finirono i Borboni di Napoli (Napoli: F. Fiorentino, 1959); I briganti di sua maestà (Napoli: F. Fiorentino, 1967). Nicola Zitara, Lorenzo Del Boca, Gigi Di Fiore, Francesco Mario Agnoli, Pino Aprile, Fulvio Izzo, Massimo Viglione, Antonio Ciano, Aldo Servidio, Roberto Martucci, Luciano Salera and Pier Giusto Jaeger are among the Italian scholars who have also supported the historical revisionism of Italian Risorgimento. Among the English-speaking historians interested in revisionism: Denis Mack Smith, Cavour and Garibaldi (Cambridge: Cambridge University Press, [1954] 1985); I Savoia, re d'Italia (Milan: BUR Rizzoli, 1990); Cristopher Duggan, The Force of Destiny: History of Italy from 1796 to Today (Boston: Houghton Mifflin, 2008); Martin Clark, The Italian Risorgimento: Still a Controversial Story (Harlow, England and New York: Pearson Longman, 2009). Lucy Riall, Garibaldi: Invention of a Hero (New Haven: Yale University Press, 2007). 
from the preceding ones. The creation of a "public enemy" justified the reactionary and violent measures of the liberal-monarchic government and served to prevent the risk of a democratic republican regime. ${ }^{34}$ As with every representation, both the Italian brigands' war-indeed a civil war - and the construction of new heroes in the Catholic anti-epic of Italian nation-building ended with moral teachings, redemptions, and episodes of sacrifice.

Meanwhile, Julia DeForest Tuttle (1849-1898), Henry Morrison Flagler (18301913), James Deering, (1859-1925), and other English-speaking pioneers were busy displaying their understanding of Italian culture as they built railways, planned a city and erected palatial estates in Miami and Southeast Florida. The hotels and the villas built in burgeoning Miami replicated the symbols of status of the early modern European courts. Roze Hentschell wrote that clothing in an unworn state served in those courts "to distinguish $[\ldots]$ one nation from another" and that "donning of apparel by actual bodies often disrupted this imaginary national clarity.. ${ }^{35}$ Like early modern courtly clothing, the use of Italian Renaissance and classic architectural elements (as in the Royal Palm Hotel built by Flagler in 1897), the entrepreneurs' use of Italian classic iconography (Deering's Villa Vizcaya, 1914-1916), or their use of features easily associated with Italianità (Coral Gables' canals and gondolas) showed the pioneers' desire to develop Florida's Caribbean

\footnotetext{
${ }^{34}$ Lucy Riall, Garibaldi: Invention of a Hero (New Haven: Yale University Press, 2007), 147. Once achieved national unity in March 1861, Italy had a monarchic government centered on a liberal constitutional system, with a pseudo-Parliament and with limited voting rights (universal male suffrage was approved only in 1912).

${ }^{35}$ Roze Hentschell, "Treasonous Textiles: Foreign Cloth and the Construction of Englishness," Journal of Medieval and Early Modern Studies 32, no. 3 (2002): 543.
} 
environment as recognizably Italian Mediterranean and at times Spanish. ${ }^{36}$ As with clothing in the early modern courts, however, the donning of Italian Mediterranean "apparel" by a Caribbean "body" disrupted the imaginary national clarity. These elements show that Southeast Florida's developers interpreted Italianità as one of the many components of Mediterranean cultures that they reenacted and displayed in their own way. They also set the scene within which the small cohort of Italians in the region renegotiated their identity and culture.

\section{Acting. Interpreting Italianità}

To explore Italians' perceptions, actions, and beliefs in this period, I will employ Victor Turner's performance theory. According to this framework, "in cultural terms, performance is seen as pervading virtually all institutions of public expressive behavior [my emphasis]." ${ }^{37}$ My work also employs Jeffrey C. Alexander's “cultural pragmatics" to demonstrate that in the post-unification years (1861-1910), Italians created discursive

\footnotetext{
${ }^{36}$ The Italianate style of architecture represented a phase of the 19th century Classical architecture. Italian was not only the linguistic but also the architectural vocabulary that made references to the Italian Renaissance architecture and inspired North American Palladianism and Neoclassicism. The Italianate Style blended with the aesthethics of the Picturesque movement. For the Royal Palm Hotel, see Braden, Susan R. "Florida Resort Architecture: The Hotels of Henry Plant and Henry Flagler." Order No. 8805648, The Florida State University, 1987. http://ezproxy.fiu.edu/login?url=http://search.proquest.com/docview/303466376?accountid=10901. For Vizcaya, see Witold Rybczynski and Laurie Olin, Vizcaya: An American Villa (Philadelphia: University of Pennsylvania Press, 2007). For Coral Gables and the gondolas, see Sunny Isles Property to be the Modern Venice of America Created by the Golden Wand of Millionaire Harvey b. Graves," The Miami Herald 11, no. 272 (1921, 24 August 1921).

${ }^{37}$ Victor Turner, The Anthropology of Performance (New York: PAJ Publications, 1986), 81.
} 
conceptions of Italianità by staging a "national drama of sorts." ${ }^{38}$ Cultural pragmatics examines meanings, processes, social situations, subjects, and power as elements of cultural enactments. "Performances" are the organizations' rituals, which emerged with the development of complex societies and in parallel with the rise of the public sphere as a forum for organized debate. Cultural pragmatics, therefore, proposes to understand the social dynamics of communities as a sort of a public stage. ${ }^{40}$ Here, the historical actors project "performance of their reasons, dramas tailored to audiences whose voices have become more legitimate references in political and social conflicts." ${ }^{41}$

Aspects of the Italian social interactions in Italy and in the United States in the four decades covered by this study replicated symbolic theatrical elements and the existence of a public stage. Inauthentic and artificial social actions and defective misesen-scène explain significant developments in these two countries. Italians in Italy, as both audience and actors, participated in unsuccessful republican revolutions with patriots like Giuseppe Mazzini (1805-1872) and Giuseppe Garibaldi (1807-1882) in the years of the

38 Jeffrey C. Alexander, Bernhard Giesen, and Jason Mast, Social Performance: Symbolic Action, Cultural Pragmatics, and Ritual (Cambridge: Cambridge University Press, 2006).

${ }^{39}$ Structuralist theories have a linguistic background in Ferdinand de Saussure's work, organized after his death in the 1915 text Course in General Linguistics. Structuralism considers meaning as a text formed by patterns that create relative autonomy, while pragmatist theories look at meaning as the product of individual and social practices which are to be analyzed as reflections of material interest and power.

${ }^{40}$ For the concept of public sphere, see Jürgen Habermas, The Structural Transformation of the Public Sphere (Cambridge: MIT Press, 1991).

${ }^{41}$ Jeffrey C. Alexander, Bernhard Giesen, and Jason Mast, Social Performance: Symbolic Action, Cultural Pragmatics, and Ritual (Cambridge: Cambridge University Press, 2006). 
Risorgimento (1815-1861). ${ }^{42}$ They also allowed conflicts to paralyze the Italian political system during the years of a monarchic-liberal government (1861-1922). Later, Benito Mussolini (1883-1945), a clever interpreter of signs, exploited this institutional fragility and seized the moment to supplant the liberal government in Italy with the fascist regime (1922-1943). In the same years, in the United States, most Italian immigrants, confronted by the difficulty of redeeming their past poverty for better living conditions, were hindered by prejudice, legal resolutions, and working hardships. Success stories emerged when Italians interpreted "background" symbols and "foreground" scripts in suitable ways for their advancement.

\section{Understanding what was expected of them in their new spaces helped Italian} immigrants to adjust successfully. ${ }^{43}$ The numerous works that helped shape the urban and architectural landscape in Southeast Florida, for example, were the product of the apt

\footnotetext{
${ }^{42}$ The Italian Risorgimento was a period of political and social tumults and claims to independence from foreign influence in Italy. It began after the 1815 Congress of Vienna, which sanctioned the end of Napoleonic rule in the peninsula, and was completed by the proclamation of the Italian State in 1861 and the 1870 capture of Rome from the Pope. The situation in Italy after the Congress of Vienna was that of a country divided into various states and controlled, directly or indirectly, from Austria in the north, the Pope in the center and the Bourbons in the south. Members of the Italian movement for independence looked at Victor Emmanuel II (1820-1878), king of Savoy and Piedmont, as the only one able to unite the country. Indeed, Victor Emmanuel and his minister Camillo Cavour (1810-1861) were interested in implementing an international strategy to consolidate Piedmont's position in Europe. They opened negotiations with Garibaldi, who was, along with Mazzini, one of the leaders of the Italian revolutions for independence in the 1840s. Garibaldi agreed to cooperate with Cavour in order to reach the goal of Italy's unification. After a series of independence wars and revolts, in 1861 the unification of Italy was then proclaimed, even if it still lacked Lazio, Veneto and Trentino.

${ }^{43}$ The region of wetlands in the Southern point of Florida has received the nickname "river of grass" after Marjorie Stoneman Douglas' homonym book, published in 1947. Since then, "river of grass" has been used to designate the geographic portion of Florida which is, in part, also the object of this dissertation. See Marjorie Stoneman Douglas, The Everglades: River of Grass (New York: Rinehart\&Company, 1947). The descriptor "River of Grass" set the scene for an effective "public stage" in this area.
} 
representation of two specific traits of Italianità: artistry and craftsmanship. Wealthy Anglo American patrons pursued those attributes to create an American renaissance $\grave{a}$ la italiana (in the Italian style). In the "public stages" of villages and cities in Italy, in the metropolises of North America, and in Miami and its surrounding land, performative behavior influenced social order. ${ }^{44}$

\section{Conclusion}

By 1900, mass emigration had emerged as a response to Italy's aspiration to imperial and cultural influence abroad and nation-building challenges at home. ${ }^{45}$ The general census of 1861 certified the existence of Italian settlements in European countries, within the Mediterranean basin, and in the Americas. ${ }^{46}$ As a consequence of the data collected in the census, after the 1880 s Italian leaders began to pay attention to emigration. It was only in 1901, however, that the Italian foreign minister Giulio Prinetti (1851-1908), under Prime Minister Giuseppe Zanardelli (1826-1903), also responsible for Italy's possessions in Africa, drafted the first law to regulate emigration to Europe

44 For an extensive discussion of ethnic groups and boundaries see. Fredrick Barth, Ethnic Groups and Boundaries: the Social Organization of Culture Difference (Boston: Little Brown and Co., 1969).

${ }^{45}$ Mark Choate, Emigrant Nation: The Making of Italy Abroad (Cambridge and London: Harvard University Press, 2008); Alberto Aquarone, “Politica Estera e Organizzazione del Consenso Nell' età Giolittiana," Storia Contemporanea 8 (1977).

${ }^{46}$ Italian Census, 1861.

http://www3.istat.it/dati/catalogo/20120404 00/la conta degli italiani.pdf). 
and the Americas. By 1911, several other decrees had followed. ${ }^{47}$ The Italian state's $^{\prime}$ establishment of direct and secure conduits for emigrant remittances illustrates its involvement in channeling emigration and preserving some measure of expatriate loyalty. ${ }^{48}$ In presenting the first draft of an emigration law in 1900, two exponents of the Liberal government of those years, Edoardo Pantano (1842-1932) and Luigi Luzzatti (1841-1927), argued that

Emigration, made necessary by overwhelming population density, by want, by the vocation of our history, does not tolerate any obstacle and, though caused by misery, resolves itself in wealth, honor, and glory benefitting our country, because without an ambition of political domination our natural colonies are establishing themselves in Latin America; emigration currents are determined by the great law of vital competition and their final results are wiser than any art of Government. ${ }^{49}$

Italian emigrants internalized and reflected the government's insistence on loyalty in their acts abroad. If the 'brigands' problem' was Victor Emmanuel II's invention to disguise his army's repressive acts of brutality against farmers and peasants, in the United States the government resorted to claims of "anarchism" to justify discrimination against Italians or utilized stereotyped imagery of mafia crooks and other ethnic preconceptions

${ }^{47}$ The 1901 Luzzati's Law on Emigration (No. 23 of 31 January, 1901) also established the Commissioner General of Emigration; Publication of the first Bulletin of Emigration (1902); Establishment of the Consortium for Temporary Emigration to Europe(1904); Stuttgart Treaty on Emigration (1907): Italian construction workers were allowed to subscribe to German trade unions; First Congress of Italians Abroad (1908); Law no. 538 (1910) for the reorganization of the General Commissariat of Emigration; Second Congress of Italians abroad (1911).

${ }^{48}$ Mark Choate, Emigrant Nation: The Making of Italy Abroad (Cambridge and London: Harvard University Press, 2008), 61.

${ }^{49}$ Quoted in Mark Choate, Emigrant Nation: The Making of Italy Abroad (Cambridge and London: Harvard University Press, 2008), 60. 
to validate racism. The new spaces to inhabit in foreign lands could be hostile. Italian immigrants had to negotiate safe boundaries again, and engage in new actions. ${ }^{50}$

The few Italians who reached Miami and Southeast Florida became artists, some achieved middle-class positions, and others remained laborers. ${ }^{51}$ These roles depended on their ability to interact with the setting they found as well as their attitudes towards new political, cultural, and religious élites. They settled in the area amid employers, coworkers, neighbors, and other migrants working to build up the area once Henry Flagler's trains had reached Miami.

At the turn of the twentieth century, the peculiarities of Miami and its immediate hinterland were attractive for a number of reasons. A mere railroad terminal at first, Miami (and much of Florida) was rural. Like the rest of the South, it lagged behind the North in many respects. Within the first decades of its founding in 1896, however, it grew so quickly that it was dubbed the Magic City and soon became a New South city ${ }^{52}$ Its

${ }^{50}$ Richard Bauman, Verbal Art as Performance (Rowley, MA: Newbury House, 1977), 44.

${ }^{51}$ Douglas A Blackmon, Slavery by Another Name: The Re-enslavement of Black People in America from the Civil War to World War II (New York: Doubleday, 2008).

52 Arva Moore Parksused this expression to explain Miami's sudden growth to become a city, but in 1939 Ira De A. Reid reported that one Bahamian migrant remembered that "Miami was a young Magic City where money could be 'shaken from trees"'. Quoted in Raymond Mohl and George Pozzetta, From Migration to Multiculturalism: A History of Florida Immigration, The new history of Florida, Michael Gannon (Gainesville: University Press of Florida, 1996), 399; Arva Moore Parks, Miami: The Magic City (Miami: Centennial Press, 1991), 12. 
promise as a tourist destination drew an assorted sample of Northern and Midwestern Americans in the 1890 s. $^{53}$

Imagined Italianità arrived before Italian immigrants as one of the Mediterranean marks of distinction adopted by Anglo entrepreneurs to civilize this Southern frontier. Some brochures and pamphlets of the time nicknamed Florida the "new Italy of America," in spite of the fact that only a relatively small number of Italians settled in the region. ${ }^{54}$ With the exception of a few specific references in a 1939 treatise by political scientist Bruno Roselli and extensive research by George Pozzetta and Gary Mormino into the Italian immigrant world in Tampa, these Italians have not received much scholarly attention. ${ }^{55}$ In Miami and its hinterland, however, they formed an eclectic and active cluster. A comparison of Miami's censuses and city directories illustrates that the

53 "Building the Overseas Railroad: Newspaper Clippings October 1905 to December 1906, Preserved by William J. Krome and the Krome Family", Tavernier: Jerry Wilkinson, 1995. Volume 190506. See July 16, 1906, p. 105; August 11, 1906, p. 115; and August 15, 1906, p.118; Raymond Mohl and George Pozzetta, From Migration to Multiculturalism: A History of Florida Immigration, The new history of Florida, Michael Gannon (Gainesville: University Press of Florida, 1996), 399.

${ }^{54}$ J. F. Bartholf and F. C. M. Boggess, South Florida, the Italy of America: Its Climate, Soil and Production (Charlotte Harbor, Manatee Co., Florida: Ashmead Bros., 1881); Arva Moore Parks, "The Daddy of Miami," in Memoirs and the History of Miami, by John Sewell (Miami: Arva Parks \& Co., 1987); "Miami: The Magic City," in Miami: The Magic City (Miami: Centennial Press, 1991).

${ }^{55}$ Bruno Roselli, The Italians in Colonial Florida; a Repertory of Italian Families Settled in Florida Under the Spanish (1513-1762, 1784-1821) and British (1762-1784) Regimes, (Jacksonville: Drew Press, 1939); Gary Ross Mormino and George E. Pozzetta, The Immigrant World of Ybor City:Italians and Their Latin Neighbors in Tampa, 1885-1985 (Urbana: University of Illinois Press, 1987). 
circulation of Italians within the city and its neighborhoods increased steadily from the 1890 s to the late 1930 s. $^{56}$

These data indicate a relation between the presence of Italian workers and the public and private works projects that were active in this period. Italian immigrants were involved in the developments financed by Miami’s first entrepreneurs, such as Henry Flagler, Julia Tuttle, William Brickell (1817-1908), Carl Fisher (1874-1939), John Collins (1837-1928), George Edgar Merrick (1886-1942), and James Deering. These patrons, "men of capital and enterprise" came after a first group of pioneers had pushed the American frontier farther south, replacing the economy of subsistence they found with a merchant economy that also relied on culture to prosper. ${ }^{57}$ They invested in the construction of bridges, schools, hotels, villas, and railways to promote and "sell" the city as a tourist destination and a paradise for orange growers. ${ }^{58}$ Modernizing industrialists chose images 'à la italiana' for their link to ideas of civilization. Through and within these projects, industrialists showed control over the "uncivilized South" also by commissioning works by Italians, and Italians left traces of their presence, lieux de

\footnotetext{
${ }^{56}$ See Chapter 5. Allan Reid Parrish, Official Directory of the City of Miami, Florida, Including General Information Concerning Churches, Lodges, Societies. (Miami: City of Miami, c. 1904; 1905; 1907; 1908; 1911) Miami Public Library; United States Federal Census 1890; 1900; 1910; 1920; 1930; 1940.

${ }^{57}$ Frederick Jackson Turner, "The Significance of the Frontier in American History," _ conference presentation at the 1893 World's Columbian Exposition, American Historical Association (Chicago, 1893).

${ }^{58}$ David Nolan, Fifty Feet in Paradise: The Booming of Florida (San Diego: Harcourt Brace Jovanovich, 1984).
} 
mémoire of Italianità as they imagined and performed it. ${ }^{59}$ Villa Vizcaya's and Coral Gables' canals and iconography, for instance, represent meaningful traces of such an historical presence and interaction.

This dissertation seeks to expand upon the scholarship on Italian immigration to North America. Interpreting patterns that constantly recurred in their everyday experience_-what linguist George Lakoff calls "kinestethic image schemas" — Italians had to understand their environment, measure their movements in space, and form mental images of new sets of symbols. ${ }^{60}$ Italians living and working in Miami only moved in apparently unbounded territories according to a design, or a script, that was conceptualized by their own cultural images and ideas as well as by those of other social groups.

"Italianità on Tour" is organized in five chapters, an introduction and a conclusion. It proposes that Italians who lived in Miami and Southeast Florida between 1896 and 1939 engaged their environment and its symbols in order to live up to the conventional Italianità in South Florida. They became historical agents and interacted, with other social groups in the area, who were their "audience."

${ }^{59}$ At Vizcaya, some Italian workers had contracts ad personam, obtained for specific expertise (De Salvo, Bucci, Quadri, Mencinni); correspondence shows that sculptors were commissioned to prepare sketches of their artworks.

${ }^{60}$ George Lakoff, Women, Fire, and Dangerous Things (Chicago: Chicago University Press, 1987). Fredrik Barth, "Boundaries and Connections." In Signifying Identities: Anthropological Perspectives on Boundaries and Contested Values, edited by Anthony P. Cohen, 17-36. London\&New York: Routledge, $2000,27$. 
Chapters one and two offer an in-depth examination of Italianità. Chapter one explores how the Italian educated groups interpreted Italianità and presents the historiography of this concept. Chapter two investigates the general public's understanding of the term. The analysis of Italian popular culture and folklore, produced between the pre-unification periods up to the years preceding World War II, is essential to accomplish this goal. Since this is a study of the Atlantic transformation of the concept of Italianità, its interpretation in the United States in general and Southeast Florida in particular, it is essential to understand how this cultural concept was conceived in Italy. Historian Peter Burke defines popular culture as "an elusive quarry" which needs mediators in order to be known by audiences over time. ${ }^{61}$ These mediators, mostly literate men, produced and collected objects and images and organized and transcribed songs and ballads. Whatever the artifact, either created by professional singers, dancers, actors, or by men and women in their domestic lives, the value of these products is key to comprehending Italianità in Italy.

Chapter three provides a discussion of Italian immigration to the United States, focusing on the concept of race and its legal implications through the analysis of two case studies: the Little Italys of New York and Philadelphia. A dissertation written by one of the first native speakers of Italian to teach the language in North America, Leonard Covello, compares the social world of Italian immigrants in North America with that of

\footnotetext{
${ }^{61}$ Peter Burke, Popular Culture in Early Modern Europe (New York: Harper \& Row Publishers, 1978), 65 .
} 
the "Italian contadino" (peasant). ${ }^{62}$ It is an important document, being both primary and secondary source. Articles, letters, and official reports from health inspectors, illustrate life in the Little Italys in Philadelphia e New York. This chapter lays the foundations to compare two Italian worlds in North America, one set in the Northeast predominantly English-speaking regions and largely non-Catholic, and the other in the Caribbean Southeast.

Chapter four concentrates on Italian immigrants in Miami and Southeast Florida. It incorporates the data from the previous chapters to show how pioneers interpreted Italianità and Italians "performed identity" in this location, the latter creating a sort of fantasy world for themselves, their employers, and settlers of other nationalities. The lives, perceptions, and actions of these Italian immigrants are explored in more detail in chapter 5, which shows that they had active roles and that, even if they were not bearers of a uniform Italian national culture, they all participated in its representations in their new context.

The conclusion demonstrates that Italianità has endured over time in Miami and Southeast Florida despite the absence of a large community comparable to others in North America in the same period. The Italian community in Miami understood their environment and produced narratives and convincing acts that allowed them to connect with the other communities in the area. Italianità remains a presence today by virtue of

\footnotetext{
${ }^{62}$ Leonard Covello, "The Social Background of the Italo-American School Child" (PhD., diss., New York University, 1944).
} 
the rules and dictates of the successful choices of Italian immigrants during this formative period of Floridian history.

Some of the sources for this research include folksongs, folktales, correspondence, memoires, and accounting records found in public and private archives belonging to intellectuals and members of the community. Tourist brochures, urban planning documentation, artworks and artifacts provide further information on Miami's socio-political and cultural milieu. Many of these texts are written in Italian, and their translations, when they appear in this work, are my best effort to reproduce them in English. 


\section{CHAPTER 1}

\section{ITALIANITÀ: DEVELOPING A TRADEMARK FOR THE NEW ITALIAN STATE, $1815-60$}

Since conditions for political unification occurred only in the late nineteenth century (1861-1870), the word 'Italian' could hardly be taken to denote one community but rather identified different peoples living in the Italian peninsula. ${ }^{63}$ The national origins' narrative developed during the times of the Eastern Roman Emperor Justinian (482-565), who ruled over the last form of a unitary state in the region after the fall of the Roman Empire in 476. During his reign (from AD 527 to 565), Justinian tried to restore the Western Roman Empire to its former greatness. ${ }^{64}$ In 568, soon after Justinian's reign, the Lombards, a Germanic tribe, invaded the Northern regions of the Italian peninsula and shattered its fragile unity, thus initiating 1300 years of internal divisions and external competitions. In the early modern and modern periods, those who traveled-merchants, missionaries, artists, architects and musicians - exported a civilization which was recognized as "Italian" to the world, but these people called themselves Venetians, Genoese, Florentines, or Lombards. ${ }^{65}$ Through the centuries, the peoples living in the

\footnotetext{
${ }^{63}$ Donna Gabaccia also problematizes the use of the terms "Italy and "Italian" before the creation of a nation and national state of Italians and Italy. See Donna Gabaccia, Italy's Many Diasporas (Seattle: University of Washington Press, 2000).

${ }^{64}$ Giuseppe Ressa, "Il sud e l'unità d'Italia" (monograph, Napoli e Palermo: Centro Culturale e di Studi Storici, 2009).

${ }^{65}$ Early modern period conventionally refers to the centuries from the end of the Middle Ages (fifteenth century) to the late eighteenth century; the modern period spans from the Napoleonic era (late eighteenth century) to the twentieth century.
} 
Italian peninsula experienced cultural markers of identity—language, religion, and history — and interpreted past and present according to their social status and to their localities. Illiterate peasants, in particular (who in the 1800s made up about 80 percent of the peoples living in the peninsula), juxtaposed the mores and values of their communities to Italianità, the trademark of the new Italian state during the first phase of the Kingdom of Italy (1861-1870) ${ }^{66}$ Italian leaders understood the importance of building a unified identity to turn it into a valuable political asset. As part of the development of nationalism at the end of the nineteenth century, politicians and intellectuals alike resorted to concepts of identity, character, history, language, religion, and culture to find common threads to 'certify' the existence of the Italian nation. ${ }^{67}$

The present chapter focuses on the ways the Italian literati investigated Italianità in the years before 1861, and how the majority of the population interpreted and performed that identity. Ultimately, in tune with the innovative ideological discourses of their time, this work centers on men and mentalities and proposes that the late nineteenth century positivist (intended as scientific) surge to research and write about these people, by the new folklorists, ethnographers, and anthropologists — most of them aristocrats and

\footnotetext{
${ }^{66}$ The social composition of the people living in the Italian peninsula in the $1800 \mathrm{~s}$ and before unification comprised farmers (55-60\%); workers in the manufacturing sectors (18\% in the South and $15 \%$ in the North); workers in trade and navigation (mostly in the Reign of the Two Sicilies, 20\%); professionals, clergy, and privileged categories (10\%). See Nicola Zitara, "La gran cuccagna dei fratelli d'Italia," Due Sicilie 2 (2004).

${ }^{67}$ The notion of an horizontal comradeship that moves steadily down or up history, to create an 'imagined community' in 'heterogeneous historical and social circumstances' is discussed in Benedict Anderson, Imagined Communities: Reflections on the Origin and Spread of Nationalism (London: Verso, 1985), 24.
} 
government bureaucrats - was central to the formation of a discourse about the Italian nation. ${ }^{68}$ Through songs and ballads, the last section of chapter one proposes a reading of Italianità that focuses on the people's voices within the larger historical narratives of the period. According to the philosopher Benedetto Croce (1866-1952) these are "men without history”, subalterns in Gramsci's sense. ${ }^{69}$

\section{Brothers Wanted for New Production: The Literati's Voice}

Italy was not alone in creating a nation in the last decades of the nineteenth century, and its interest in the popular classes was linked to the birth of nationalism. ${ }^{70}$ Italian and European intellectuals and politicians came to realize that the historical circumstances, together with the growth of labor movements born as a result of the nineteenth century Industrial Revolution, demanded a form of national alternative to the

\footnotetext{
${ }^{68}$ It is important to recall that in this period positivist intellectuals understood human nature and social conditions, history and philosophy through scientific approaches. Benedetto Croce was one of the first to repudiate positivism - of which it is said he had a horror - and proposed historicism instead. Croce explained that all historical phenomena were the product of how the human spirit (which, for Croce, did not refer to anything metaphysical or divine but was rather a synonym of "culture") constructed the world at a particular moment in a particular milieu. Croce's historicism distinguished between "men and women who are actors in history, and those who "stand passively within history", between "individuals who pertain to history, and individuals 'of nature' ". See George Saunders, "'Critical Ethnocentrism' and the Ethnology of Ernesto De Martino," American Anthropologist, New Series 95 (1993): 877-90; Benedetto Croce, "Poesia 'popolare' e poesia 'd'arte': considerazioni teorico-storiche," La critica. Rivista di letteratura, storia e filosofia 27 (1929): 406-409. The Marxist intellectual Antonio Gramsci (1891-1937) criticized Croce's historicism. Gramsci considered Croce a conservative bourgeois who opposed the struggle for a new culture, a new "humanism" which did not make distinctions between actors in history and subalterns. See Antonio Gramsci, Letteratura e vita nazionale (Roma: Editori Riuniti, 1996), 6; 126.

${ }^{69}$ The term "subaltern", taken from Gramsci, will be used in this work to indicate the majority of the population held in subordinate position by the clergy, the Papacy, aristocracy, and foreign invaders, latifundists, the Liberal élite that held government positions, and Fascists—in chronological order.

${ }^{70}$ In the 1830s-1840s, political upheavals also took place in the German states, Denmark, Hungary, Switzerland, Western Ukraine, Greater Poland, Belgium, Ireland, among other places.
} 
models of the past, one in which all individuals participated and felt a sense of belonging to the same community. Nationalism in Italy, and in other European countries, began with the resistance against Napoleon (1769-1821), who controlled much of continental Europe in the period 1803-14. The process of independence from foreign rule and national unification led to the $1830-48$ revolutions. At its dawn, participants in political and intellectual life considered nationalism a liberal ideology and as expression of selfdetermination, but statesmen such as Camillo Cavour (1810-61) (and Otto von Bismarck (1815-98) in Germany) soon turned it into the instrument of reactionary and militarized states.

Even before unification, in the 'core' period of the Italian Risorgimento, from 1815 to 1860 , intellectuals were busy imagining the Italian community. They used the cultural 'uniqueness' and 'superiority' of their people to assert a right to statehood. Some of them fought for this cause. They looked at the political and economic backwardness of Italy and at its inhabitants' disinterest in anything that went beyond their municipalities, as a "vice." ${ }^{\text {,71 }}$ Nationalist and journalist Giuseppe Mazzini (1805-72) was one of the first to write "de' vizi che contrastarono al concetto rigeneratore di farsi via tra gli ostacoli"

${ }^{71}$ Historian Silvana Patriarca has extensively written on this theme. See Silvana Patriarca, Italian Vices: Nation and Character from the Risorgimento to the Republic (Cambridge: Cambridge University Press, 2010); Silvana Patriarca, "Indolence and Regeneration: Tropes and Tensions of Risorgimento Patriotism," The American Historical Review 110, no. 2 (2005): 380-408. 
(about the vices that opposed the many efforts attempted to reach regeneration among

difficulties). ${ }^{72}$ He criticized Italians' personal attachment to the "village"

We Italians, more than others, need to have the multitudes with us, because no people may have more obstacles to overcome... We have enemies inside. [...] We have a foreign army [...], we have provincial divisions, which the many centuries of common misfortune could wear down, but not destroy. We have, and this is deadly plague, lack of faith in ourselves and in our forces." ${ }^{, 73}$ Mazzini claimed that an exclusive municipalism resulted from foreign domination. He also believed that individualism was not part of the character of the peoples living in Italy ${ }^{74}$ Many of Mazzini's peers agreed, but for them individualism was not the "first" Italian vice. They were troubled more with indolence and effeminacy. The Piedmontese historian Cesare Balbo (1789-1853) wrote: "I would ask young Italians to have fun only in a virile way. ${ }^{, 75}$ In several treaties they defined indolence (ozio) as the antonym of virtue and a "label for all those characteristics which are regarded as harmful to civic life. ${ }^{, 76}$ By using Niccolò Machiavelli’s (1469-1527) idea of the republic in their rhetoric

${ }^{72}$ Giuseppe Mazzini, “D’alcune cause che impedirono finora lo sviluppo della libertà in Italia. Articolo 1," in Interessi e principii (Orig. La Giovine Italia, 1832) (Milan: Bompiani, 1944), p.3.

73 “Noi Italiani, più ch'altri, abbiamo bisogno d'avere le moltitudini con noi, perché nessun popolo forse ha più ostacoli da superare - né giova il dissimularli. Abbiamo nemici al di dentro... Abbiamo, e questa è piaga mortale, la mancanza di fede in noi e nelle forze nostre." See Giuseppe Mazzini, "D'alcune cause che impedirono finora lo sviluppo della libertà in Italia. Articolo 2," in Interessi e principii (orig. La Giovine Italia, 1832) (Milan: Bompiani, 1944), p. 20.

${ }^{74}$ Giuseppe Mazzini, "D’alcune cause che impedirono finora lo sviluppo della libertà in Italia. Articolo 2," in Interessi e principii (Orig. La Giovine Italia, 1832) (Milan: Bompiani, 1944), pp. 3-30.

75 "Io non domanderei altro alla gioventù italiana che questa facile concessione: ch'ella si diverta virilmente.” See Cesare Balbo, Pensieri ed esempi, (Florence: Le Monnier, 1844), 191-3.

${ }^{76}$ Cesare Balbo, Pensieri ed esempi, (Florence: Le Monnier, 1844), 13; 195. 
of manly virtue and female corruption, the patriots acknowledged the gendered stereotypes of the indolent and effeminate Southerner that had been circulating in Europe at least since the mid-eighteenth century, and scrambled to efface it. ${ }^{77}$ The image of indolence and effeminacy pervaded discourses about the people living in Italy both inside and outside the peninsula. Historians, writers, and politicians wrestled against the "orientalist" construct of identity that likened Southern peoples to "Orientals" by reading and writing extensively on the topic. ${ }^{78}$ Negative descriptions of Italianità so abounded in this analytical literature that one author criticized the tendency to reiterate the same observations again and again

as soon as one of the most distinguished Italians [probably d'Azeglio] uttered an unflattering evaluation of his contemporaries, it became fashionable to assert that the Italians [were] a people of little character, indifferent, slothful, skeptical, corrupt, dissimulating. ${ }^{79}$

The cultural élite struggled to craft the new Italian man, as the inherent contradiction of creating and condemning at the same time an effeminate character shows. Such a paradox defined most of the pre-unification literature on Italianità. Cesare

${ }^{77}$ Hanna F. Pitkin, Fortune is a Woman: Gender and Politics in the Thought of Niccolo Machiavelli (Chicago and London: University of Chicago Press, 1984).

${ }^{78}$ Orientalism is used in this work to convey intellectual attitudes that fabricate assumptions about people and cultures according to pre-concepts and stereotypes. It derives its name from Edward Said, Orientalism (New York: Pantheon Books, 1978). Historian Aurora Morcillo uses the term orientalization as 'the process of exotization of Spain in the Western cultural imaginary manufactured by Spanish and foreign writers alike.' See Aurora Morcillo, "The Orient Within. Women 'in-between' under Francoism," in Women in the Middle East and North Africa: Agents of Change, Fatima Sadiqi and Moha Ennaji (New York: Routledge, 2011), 260.

${ }^{79}$ Antonio Reale, Nazione e famiglia: studio intorno al carattere, (Milan: Tip. Pirola, 1878), 31. 
Balbo was a supporter of the national cause and an admirer of Charles-Louis de Secondat Montesquieu (1689-1755). ${ }^{80}$ He wrote a treaty on virtue, Delle speranze d'Italia (1844), inviting his contemporaries to abandon 'abject' features. He suggested that national resurgence and regeneration were the only means to lead Italy to its legitimate and productive place in nineteenth century Europe and within the Catholic world. ${ }^{81}$ Deciphering and imagining Italianità found the intellectual élite in dialectical positions. The Piedmontese philosopher and former Mazzinian, Vincenzo Gioberti (1801-52), for example, wrote in 1843 that Italian superiority had an ethnic basis, since the Italians descended from the Pelasgians, a mythic Mediterranean people. ${ }^{82}$ His argument made reference to the work of the Enlightenment writer Vincenzo Cuoco (1770-1824). ${ }^{83}$ The theme of resurgence circulating in those years called then for the re-awakening of a past state of splendor, as the first verses of the soon-to-be Italian national anthem sang "Brothers of Italy, Italy has woken." ${ }^{84}$ At the same time, however, Gioberti criticized

${ }^{80}$ Charles-Louis de Secondat, Baron de Montesquieu (1689-1755) was a French intellectual who wrote on the varieties of human societies and governments. He also argued that climate may influence the nature of man and his society. See Charles-Louis de Secondat de Montesquieu, Defense de l'Esprit des loix (Geneva: Barrillot, 1748).

${ }^{81}$ Cesare Balbo, Delle speranze d'Italia, (Capolago Cantone Ticino: Tipografia Elvetica, 1844).

${ }^{82}$ Vincenzo Gioberti, Del primato morale e civile degli Italiani (Brussels: Meline, 1843), CDLXII.

${ }^{83}$ Vincenzo Gioberti, Del primato morale e civile degli Italiani (Brussels: Meline, 1843); G. Durando, Della Nazionalità Italiana. Saggio Politico Militare (Paris: A. Franck, 1846); see also Vincenzo Cuoco, Platone in Italia (Napoli: 1804). In this work, Vincenzo Cuoco celebrates Italy as the ancient and historical site of wisdom.

${ }^{84}$ Italian national anthem, Goffredo Mameli, Il canto degli Italiani (Genoa: 1847). In Italian: "Fratelli d'Italia / l'Italia s'è desta [...]." 
Balbo's idea of Italy's perennial primacy. Like Gioberti, many compared Italy negatively with other European countries by stressing the gulf in socio-economic terms that lay between them. Even if a patriotic sentiment animated these intellectuals' examinations, they could not ignore the fact that while the English élite was always busy in some activities even in their leisure time, in Italy "the little count and the little master are from their infancy raised into softness, laziness and insignificance", as Gioberti noted. ${ }^{85}$

Liberal writers who denounced the troublesome character of their compatriots identified different specific causes from the moderates, but they also agreed that history played a large role in Southern identity and, as the intellectuals of the Risorgimento, those in the 1860 s and 1870 s attributed most of the blame on the institutions and habits of the past. The criticisms of Italianità derived from comparisons with positive examples provided from other nations, in particular Great Britain, the country of Scottish author Samuel Smiles (1812-1904) and the nation that best exemplified Smiles' beliefs and attitudes towards life. ${ }^{86}$ Poet Giacomo Leopardi (1798-1837) captured the feeling: "Italians laugh at life, laugh more, and with more truth and intimate conviction of contempt and aloofness than others do in any other nation. ${ }^{987}$ Writer and journalist

\footnotetext{
${ }^{85}$ See Vincenzo Gioberti, Del primato morale e civile degli Italiani (Brussels: Meline, 1843), clxiii; G. Durando, Della nazionalità Italiana. Saggio politico militare (Paris: A. Franck, 1846).

${ }^{86}$ Smiles believed that hard-work produced good laws and a strong economy. Hard-working men were the strongest bulwark against bad statesmen. He also opposed the idea of an intrusive government, which might weaken men's best qualities over time. In the 1870s, his work was translated and read in Italy. See Samuel Smiles, Self-Help with Illustrations of Conduct and Perseverance (London: J. Murray, 1859).

87 "Gli italiani ridono della vita: ne ridono assai più, e con più verità e persuasione intima di disprezzo e freddezza che non fa niun'altra nazione.....Le classi superiori d'Italia sono le più ciniche di tutte le loro pari nelle altre nazioni. Il popolaccio italiano è il più cinico dei popolacci.". See Giacomo Leopardi,
} 
Cristina di Belgiojoso (1808-71) wished that the Italians would imitate the "marvelous industriousness of the English masses". I interpret these comments as an unconfessed manifestation of an inferiority complex that afflicted the intellectual élite and that was not exclusive of Italy but also present in Spain and other Mediterranean countries. ${ }^{88}$

The historical context certainly informed the views of these scholars. In this period, Hegel's philosophical reflections on history circulated for the first time in Europe. ${ }^{89}$ Hegel pointed to the importance of the Old World (Europe, Asia, and Africa) in world history, and to the centrality of Europe within this triad. ${ }^{90} \mathrm{He}$ also argued that since the Mediterranean Sea united the three constituent parts of the Old World, it "was the axis of universal history." ${ }^{91}$ In this context, European scholars forged a telescopic

Discorso sopra lo stato presente dei costumi degl'italiani, (Venice: Marsilio, 1989 [1824], 66; Maura O'Connor, The Romance of Italy and the English Political Imagination (New York: St. Martin's Press, 1998); F. Mazzocca, “L'Iconografia Della Patria Tra 1'Età Delle Riforme e 1'Unità,” in Immagini Della Nazione Dell'Italia del Risorgimento (Rome: Carocci, 2002), 89-11.

${ }^{88}$ In the case of Spain, Morcillo argues that Catholicism and Spain's Islamic and Jewish historical roots are the 'cultural monoliths' associated with Spanish identity, which have contributed to place Spain in a subaltern position within Europe. See Aurora Morcillo, “The Orient Within. Women 'in-between' under Francoism," in Women in the Middle East and North Africa: Agents of Change, Fatima Sadiqi and Moha Ennaji (New York: Routledge, 2011), 259.

${ }^{89}$ Hegel's Lectures on Philosophy of History was published posthumously and for the first time in 1837. See Georg Wilhelm Friedrich Hegel, Lectures on the Philosophy of History (London: George Bell and Sons, 1902 [first ed. 1837]).

${ }^{90}$ Georg Wilhelm Friedrich Hegel, Lectures on the Philosophy of History (London: George Bell and Sons, 1902 [first ed. 1837]), 135.

${ }^{91}$ Georg Wilhelm Friedrich Hegel, Lectures on the Philosophy of History (London: George Bell and Sons, 1902 [first ed. 1837]), 143-4. Philosopher Enrique Dussel writes that Hegel was not interested in the New World of the Americas as this was still "in formation." See http://enriquedussel.com/DVD\%20Obras\%20Enrique\%20Dussel/Textos/23-1/03chapter1pp17-26.pdf retrieved 07/21/2013. 
interpretation of the centrality of Europe in the Mediterranean, of Northern countries within Europe, and — for Hegel—of "Germany, France, Denmark, the Scandinavian countries" within North Europe. According to this theory, the heart of universal history lay within Northern Europe. These regions represented the heart of civilization. This philosophical appraisal predisposed scholars in the Southern appendices of the Continent to understand their own identities in "orientalized" terms, as Aurora Morcillo's work on Spain's identity has also demonstrated. ${ }^{92}$ It also explains their sometimes contradictory positions. A pessimist, Leopardi reflected that "The upper classes of Italy are the most cynical of all their peers in other countries. The Italian populace is the most cynical people. ${ }^{.93}$ At the same time, he lamented:

She [Italy] once was great, but, oh, behold her now?

Why hast thou fallen thus, oh, why?

Where is the ancient force?

$[\ldots]$ Will none defend thee? No?

No son of thine?

For arms, for arms, I call. ${ }^{94}$

${ }^{92}$ Aurora Morcillo, “The Orient Within. Women 'in-between' under Francoism," in Women in the Middle East and North Africa: Agents of Change, Fatima Sadiqi and Moha Ennaji (New York: Routledge, 2011); True Catholic Womanhood: Gender Ideology in Franco's Spain (DeKalb: Northern Illinois University Press, 2000); The Seduction of Modern Spain: The Female Body and the Francoist Body Politic (Lewisburg: Bucknell University, 2010).

${ }^{93}$ Cristina Trivulzio di Belgiojoso, Osservazioni sul presente stato dell'Italia e sul suo avvenire (Milano: Vallardi, 1868), 81; Giacomo Leopardi, Discorso sopra lo stato presente dei costumi degl'italiani, (Venice: Marsilio, 1989 [1824], 66.

${ }^{94}$ In Italian “[...] già fu grande, or non è quella? / Perché, perché? dov'è la forza antica, / Dove l'armi e il valore e la costanza? / Chi ti discinse il brando? / Chi ti tradì? qual arte o qual fatica / O qual tanta possanza / Valse a spogliarti il manto e l'auree bende? / Come cadesti o quando / Da tanta altezza in così basso loco? / Nessun pugna per te? non ti difende / Nessun de' tuoi? [...]”. Giacomo Leopardi, "All'Italia", Canti, <eds> Gallo, N., Garboli, C. (Turin: Einaudi, 1993). 
The invocation expresses the impotence of a class overcome by the trouble of bringing the Italian national project to completion. Academics wavered from self-contempt to nostalgia and to the memory of past glory. When not indulging in self-commiseration, they presented the Italian "vices", as they called them, as the product of external forces working to eliminate Italy from the main, European, stage. These contradicting themes coalesced in the search of the cause of the fall and in the promise of vindication, as the national anthem epitomized: "Let us swear to set free / The land of our birth: / United, for God, / Who can overcome us?" 95 The expression "for God" (per Dio) is noteworthy, because it has an expletive connotation in Italian.

The Italian élite of this period agreed on the necessity of writing a script where Italians finally became — or re-became - men and soldiers. They set to work on Italy's independence and freedom from foreign travelers' influence. According to Victorian European travelers who visited or read about Italy, the character of its people did not detract anything from its "incredible beauty," as one of them wrote, and their admiration paired cruel expressions for the people who inhabited it. ${ }^{96}$ It is true that the peninsula's qualities which attracted foreign travelers contributed to draw the European middle classes to support the Italian national cause. ${ }^{97}$ However, Italian language scholars kept

\footnotetext{
${ }^{95}$ Italian national anthem, Goffredo Mameli, Il canto degli Italiani (Genoa: 1847). In Italian: “[...] Giuriamo far libero / il suolo natio: / uniti, per Dio, / chi vincer ci può? [...]”.

${ }^{96}$ Madame De Stäel, Corinne, or Italy, S. Raphael (Oxford: Oxford University Press, 1998), 97.

${ }^{97}$ Silvana Patriarca, Italian Vices: Nation and Character from the Risorgimento to the Republic (Cambridge: Cambridge University Press, 2010), 24-50; Cesare De Seta, "L'Italia nello specchio del 'Grand Tour'," in Storia d'Italia. Annali 5 Il Paesaggio, Cesare de Seta (Torino: Einaudi, 1982), 135; Jane Schneider, "Introduction: The Dynamics of Neo-Orientalism in Italy (1848-1995)," in Italy's "Southern
} 
reminding their readership that Italy's cultural superiority went beyond beauty. Catholics proposed that Catholicism was a way to recover Italians from the wretched state in which they were enmeshed. ${ }^{98}$ They worked to bring back the memory of the greatness of the Italian civilization that went hand in hand with universal, secular, and Catholic values. Generals and politicians claimed instead that to save the patria (fatherland) from foreign invaders, Italians needed to recover manly honor, because the Italian character had lost its primacy in industriousness and was very relaxed as a result of an "intentionally emasculating" education. ${ }^{99}$

Historians of that time supported the argument that masculinization through militarization was the solution to Italy's subjection to foreign powers. The republican historian Jean-Léonard-Charles Simonde de Sismondi (1773-1842) wrote the history of medieval Italy, Histoire des Republiques Italiennes du Moyen Age, where he traced the outline of the birth, growth and decadence of the Italian communes from the fall of the Roman Empire to their resurgence in the later Middle Ages, and their downfall again caused by local despots. Sismondi argued that Italianità had known moments of glory during the time of the medieval republics when Italians were free and independent and

Question": Orientalism in One Country, Jane Schneider (Oxford and New York: Berg, 1998), 1-23; Giulio Bollati, "I caratteri originali," Storia d'Italia 1 (1972): 34 L'Italiano, vol. 1 of L'Italiano. Il carattere nazionale come storia e come invenzione; Maura O'Connor, The Romance of Italy and the English Political Imagination (New York: St. Martin's Press, 1998); F. Mazzocca, “L'Iconografia Della Patria Tra l'Età Delle Riforme e l'Unità,' in Immagini della nazione dell'Italia del Risorgimento (Rome: Carocci, 2002), 89-111; Giacomo Leopardi, Canti, <eds> Gallo, N., Garboli, C. (Turin: Einaudi, 1993).

\footnotetext{
${ }^{98}$ Vincenzo Gioberti, Del primato morale e civile degli Italiani (Brussels: Meline, 1843).
}

${ }^{99}$ Vincenzo Gioberti, Del primato morale e civile degli Italiani (Brussels: Meline, 1843); Giorgio Durando, Della nazionalità italiana. saggio politico militare (Paris: A. Franck, 1846). 
provided other Europeans with the principles of civilization and governments. $\mathrm{He}$ claimed it was when the French and the Spaniards arrived and deprived Italians of their liberty that corruption and decline began again. The absolute domination of the Catholic Church in the peninsula from the Counter-Reformation onward gave the Italian character the final blow: the clergy embodied corruption, ritual and pomp, which they valued more than substance. Italians learned from leaders of the Catholic Church and began to deceive and ignore their consciences. In this era, continued Sismonde, the spectacle of the Italians' association with religious practices intermingled with their disregard of the duties and virtues of Christianity. That conclusion was enough to support Sismondi's argument. His work offered the historical argument to what many foreigners and Italians considered the epitome of Italian degeneration: the "shameful" habit of 'cicibeismo' (gallantism). According to Sismondi, while during the republican era "the inclination to work had been, until the mid-sixteenth century, the distinctive quality of the Italians," especially under Spanish control Italian nobility began to disdain all kinds of work. (For Sismondi, the Spanish rulers were the epitome of "Castilian prejudices.") ${ }^{100}$ Along with a general disapproval of work, the new custom of primogeniture brought indolence and laziness to many young men. The role of cicisbeo was borne out of the necessity to engage the sons and cadets of the Italian nobility in some activities at court or in the

\footnotetext{
${ }^{100}$ J. L. C. De Sismondi Sismonde, Histoire des républiques italiennes du moyen age (Brussels: A. Wahlen, 1839).
} 
aristocratic palaces. ${ }^{101}$ "Cicisbeo" was a man (a friend or lover, never a spouse) who accompanied ladies everywhere in society and public. Sismondi claimed that approving the presence of women's lovers in public caused disorder and confusion. Furthermore, Italians (he probably meant the husbands) "ceased to be men." ${ }^{102}$ Since the term cicisbeo referred to a "cavalier servente" and to a "damerino", (a man who paid excessive attention to appearance in society and devoted most of his time to the company of women), the word cicisbeo came to be used to indicate an effeminate and indolent man. The cicisbeo became the subject of late eighteenth century anti-aristocratic satires such as Il Giorno (1763-65) written by the poet Giuseppe Parini (1729-99). Cicibeismo (gallantry) obviously continued to preoccupy, if in the nineteenth century intellectuals were still writing about it.

The cry "we are ready to die" demonstrates the urgency to regenerate Italians, even through war, if necessary. As men fought wars, Italians would have to undertake a profound moral change to shed male laziness and effeminacy. Only then would they recover their ancient greatness and their rightful position in the civilized world. A Milanese newspaper began publication in April 1848 with the title: "L'Italia rigenerata" (regenerated Italy) indicating that along with Sismondi and Mazzini, many hailed the

\footnotetext{
${ }^{101}$ Silvana Patriarca, "Indolence and Regeneration: Tropes and Tensions of Risorgimento Patriotism,” The American Historical Review 110, no. 2 (2005): 380-408.

102 J. L. C. De Sismondi Sismonde, Histoire des républiques italiennes du moyen age (Brussels: A. Wahlen, 1839).
} 
1848 revolutions as the sign of the renewal that was arriving. ${ }^{103}$ For these radicals, such drastic means were to bring the change that Italians needed to cleanse the mark of effeminate, servile and indolent cicisbei. What was more evocative of their desire to masculinize Italy's people than the chant "Let us join in a cohort, we are ready to die, Italy has called!" The call, composed in 1847, would become part of the new nation's anthem. ${ }^{\mathbf{1 0 4}}$ Revolutionaries believed manly actions and popular insurrections would liberate Italy and permit Italians the recovery of their true Italianità. As such, insurrection had a moral value. ${ }^{105}$ Not all agreed. Some moderates criticized radical republican plans and claimed that popular revolutions were a counter-productive evil because only moderation would bring change, even if moderation meant a longer time to subvert the deep-rooted habits of indolence and passivity.

Moderates proposed a 'domestic' solution: Italian women had to generate and grow Italians who would love and honor their motherland. To achieve the goal, women had to devote themselves to their families and abandon all relations with society. ${ }^{106}$ Contemporary scholars of gender and nationalism see the emergence of the new sexual

\footnotetext{
${ }^{103}$ The liberal-democratic L'Italia rigenerata: giornale di politica, scienze, letteratura, teatri , arti e commerci was a bi-weekly publication.

${ }^{104}$ Italian national anthem, Goffredo Mameli, Il canto degli Italiani (Genoa: 1847). In Italian: “[...] Stringiamci a coorte, / siam pronti alla morte. / Siam pronti alla morte, / l'Italia chiamò. / Stringiamci a coorte, / siam pronti alla morte. / Siam pronti alla morte, / l'Italia chiamò!” Italian national anthem, Goffredo Mameli, Il canto degli Italiani (Genoa: 1847).

105 Lucia Riall, Garibaldi: Invention of a Hero (New Haven: Yale University Press, 2007).

${ }^{106}$ Here the reference is to the aristocratic women of the time, such as Madame de Stael and the likes.
} 
morality that characterized the Italian nineteenth century nationalism. ${ }^{107}$ Some literate women also insisted that Italy needed both courageous men and modest women. ${ }^{108}$ Other women engaged in the patriotic movement, however, disapproved the patriarchal stance of the Italian male patriots on women's education. To poet and patriot Caterina Franceschi Ferrucci (1803-1887), who supported women's domestic role, the promoter of suffrage and legal reforms in Italy, Anna Maria Mozzoni (1837-1920) replied in 1864 "The times are changing. Despotism, which has enchained any man with the most indifferent of human acts, is creaking on its hinges, and is shaking and crumbling." The term "regeneration", even if associated with republicanism, was used by conservative liberals and became even more popular than resurgence (risorgimento). It is an important concept, because regeneration implied re-birth, while resurgence evoked demise.

"Regeneration" became popular because it suggested the gendering of the formation of the Italian identity. Italianità had to be "conceived," be borne anew of a

${ }^{107}$ George L. Mosse, The Nationalization of the Masses: Political Symbolism and Mas Movements in Germany from the Napoleonic Wars through the Third Reich (Ithaca and London: Cornell University Press, 1975);

${ }^{108}$ Caterina Franceschi Ferrucci, Degli studi delle donne (Turin: Pombam 1853); Letizia Panizza and Sharon Wood, eds, A History of Women's Writing in Italy (Cambridge: Cambridge University Press, 2000), 359.

109 “I tempi avanzano. Il vecchio edificio del dispotismo, che tutto l'uomo incatena dal piú intimo escogitato dell'anima fino al piú indifferente degli atti umani, scricchiola sui cardini, scrolla e rovina." See incipit to Anna Maria Mozzoni, La Liberazione Della Donna (Milano: Gabriele Mazzotta Editore, 1975 [orig. 1864]). 
fertile Italy, not simply resurrected from death. ${ }^{110}$ The iconography of the period abounded of images of Italy as la Donna Turrita (the woman bearing a tower), a prosperous woman wearing a mural crown that resembled fortification walls. ${ }^{111}$ Umberto Eco suggests identifying the intended audience of the female personification of the nation in order to understand the reasons of such iconography. ${ }^{112}$ Obviously, a male spectator was invited to engage with la Donna as son, lover, or brother.

The appropriate performance required the viewer to be grateful to the mother, devoted to the lover, and protective of the sister. Such a role demanded manliness. The representation of Italy as a woman anticipated the creation of a bond between the man/citizen and the woman/nation. The importance of gendered tropes in national selfrepresentation was significant because it contributed to the gendering of nation formation, and adds to sociologist Nira Yuval-Davis' argument that the construction of nationhood involves specific notions of both 'manhood' and 'womanhood'. ${ }^{113}$ Garibaldi's enterprises also helped to spread a new model of heroism and to dispel prejudices about the indolent

\footnotetext{
110 "Regeneration" is also a national movement in Spain at the time of the disaster after the 1898 Spanish-American War.

${ }^{111}$ Gwyn Davies adds "In the Roman empire all provinces were depicted as women in their iconography, each with special characteristics. The mural crown was reserved for those provinces with large numbers of cities and which were more "civilized." See Gwyn Davies, notes, November 2013.

${ }^{112}$ Umberto Eco, Lector in Fabula: la cooperazione interpretativa nei testi narrativi (Milano: Bompiani, 1979); Joan B. Landes, Visualizing the Nation (Ithaca, NY: Cornell University Press, 2003). The iconography of nation-formation of the eighteenth and nineteenth centuries is rich of examples. Besides Italy' Donna Turrita, there is France's Marianne, Germany's Germania, Great Britain's Britannia, Spain's Esperia, and the United States' Lady Liberty.

${ }^{113}$ Nira Yuval-Davis, Gender and Nation (Thousand Oaks: Sage Publications Ltd., 1997).
} 
nature of Italians. As a result, a new image of these people gradually began to circulate in Europe. The nation was taking shape, but critics abounded.

For republicans, the Italian state was born with original sin. Mazzini, for example, did not like unification as it was conceived of in 1861, and held the Italian "spirit" responsible for the failure. Had a true revolution taken place, the republicans believed, power would be in the hands of a new generation toughened by the struggle, and not in those of the same people old grown in the morally and politically contaminated climate of the existing regimes. ${ }^{114}$ Not only had the Piedmontese monarchy won, destroying Mazzini's republican dream, but the victory was achieved through an alliance with France's Napoleon III. ${ }^{115}$ Mazzini expressed his disappointment with unforgiving words, articulating his discontent, and that of other republican revolutionaries, at the sight of not only a "monarchical" but also an imperfect unification. Venetia and Rome were still missing in the Union. Fighting a war was the only honorable solution but when it finally took place the Italian forces lost at both Custoza and Lissa in $1866 .{ }^{116}$ These defeats brought further humiliation to an already humbled country and rekindled the long-held

\footnotetext{
114 Pasquale Villari, "I rimedii," in Le Lettere Meridionali e Altri Scritti Sulla Questione Sociale in Italia (Florence: Le Monnier, 1878), 61-76.

115 Giuseppe Mazzini, “La questione morale,” Il dovere, 1866, 9 March 1866.

116 The battles of Custoza and Lissa took place in 1866, when the Italian force, allied with Prussia, fought against Austria to capture Venetia, Friuli Venezia Giulia, and Trentino Alto Adige, the "terre irredente" (unredeemed territories). They concluded with the Austrian Empire's victory over the Italian force.
} 
stereotypes about the Italians' lack of military élan. ${ }^{117}$ The belief that past experiences had corrupted their compatriots made servile by centuries of domination, depressed and influenced these first Liberal intellectuals. They dreamt of change and once again reflected on nature of Italians, but for the first time, these ruminations encompassed not only the military and political leadership, but all Italians,

the illiterate multitudes, the soulless bureaucrats, the ignorant professors, the infantile politicians, the impossible diplomats, the incompetent generals, the inexperienced worker, the patriarchal farmer, and the rhetoric which eats into our bones ${ }^{118}$

became liable of Italy's performance on internal and foreign stages. Public moralists all agreed that the proclamation of the Kingdom of Italy in 1861 was the beginning of the nationalistic project which forces in every field (literature, music, politics, diplomacy, international relations, rituals, iconography, and history) had to bring to fruition. With the coming of the nation, the concept of 'being Italian' also had to be reinforced. In 1868, the literary historian and five times Minister of Education Francesco De Sanctis (181783) repeated a recurrent adage in those years: "Italy exists but the Italian subject is still missing." 119

${ }^{117}$ Giuseppe Mazzini, "I Collaboratori della Giovine Italia ai loro concittadini," in Scrittti Politici Editi e Inediti (Imola: Galeati, 1907-43). The Italian dramatist Vittorio Alfieri (1749-1803) joined Cesare Balbo, Vincenzo Gioberti, and Mazzini in the criticism.

118 Pasquale Villari was one among the most vociferous supporters. See Pasquale Villari, "Di chi è la colpa? O sia la pace e la guerra," Il Politecnico II, no. 4 (1866): 193.

${ }^{119}$ Francesco De Sanctis, “Il Mezzogiorno e lo Stato Unitario," L'Italiano, 1868, 22 December 1868, 293. 


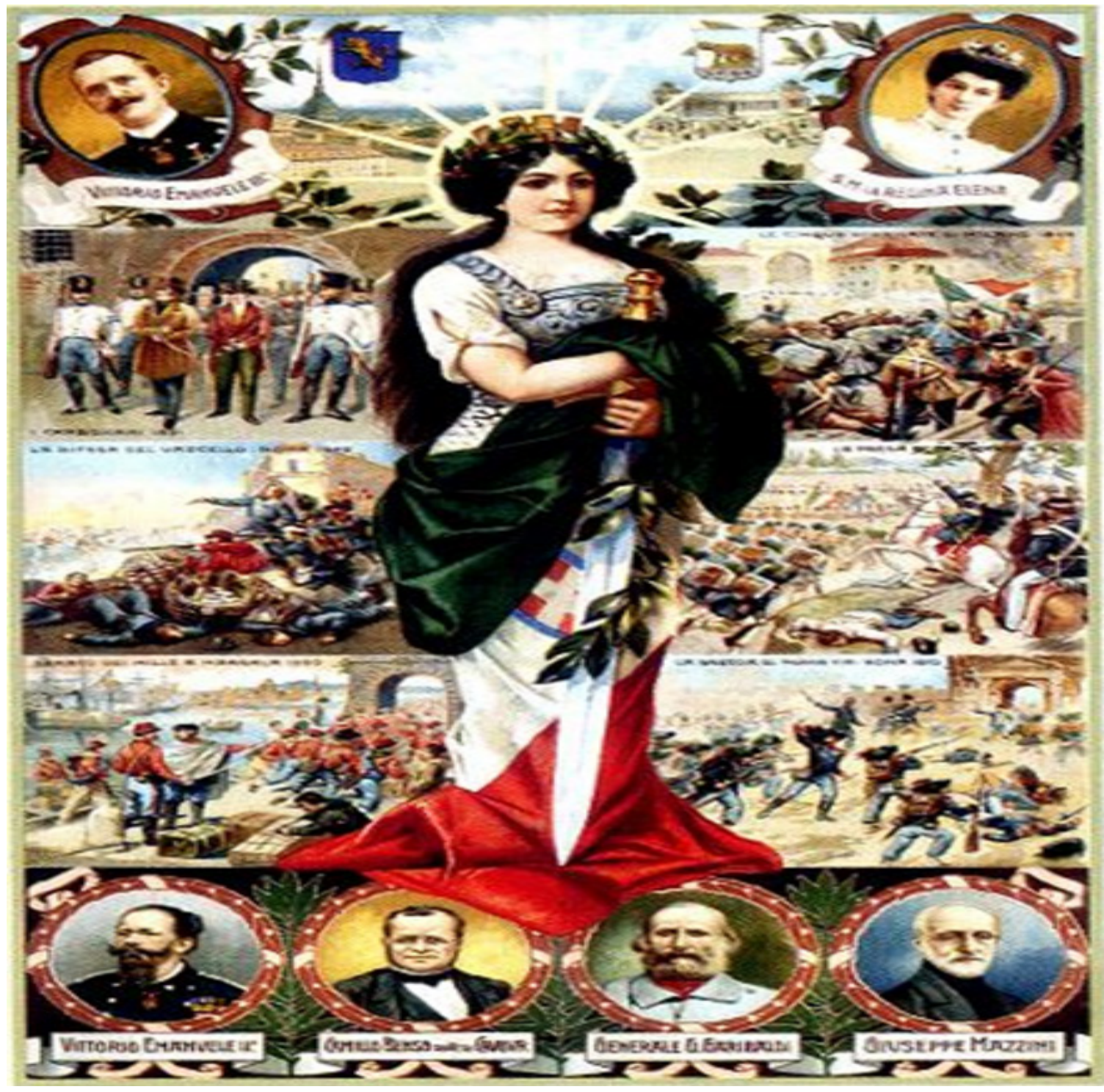

Figure 1. Allegory of Italia Turrita (1911). Lithography. One of a set of 10 commemorative postcards by painter Colombo, created to celebrate the 50th anniversary of the proclamation of the Kingdom of Italy. Collection Nuccio Mulè.

The majority of the people in the Italian peninsula looked at la Donna Turrita as a woman beyond their reach. Some even ignored her existence. An outpouring of texts, literature, patriotic songs and other media targeted the people and encouraged them to rise up from secondary roles, to those of protagonists. Mameli's hymn incited to unity 
Let us unite, let us love one another, for union and love reveal to the people

the ways of the Lord

[...] From the Alps to Sicily,

Legnano is everywhere;

every man has the heart, and the hand of Ferruccio ${ }^{120}$

and to rebellion

The children of Italy are all called Balilla, every trumpet blasted sounds of the vespers. $^{121}$

The ruling class, through the work of intellectual groups, made tropes of common good seem the result of direct, popular participation. Every man had the heart and the hand of a captain; all children of Italy could lead a revolt. All Italian individuals, including those who had until then stood "passively within history," were invited to "pertain to history." 122 Obviously, they needed some preparation, and explanatory texts appeared to serve the scope. De Sanctis was one such scholar who greatly contributed to the Italian

${ }^{120}$ Italian national anthem, Goffredo Mameli, Il canto degli Italiani (Genoa: 1847). In Italian: "Uniamoci, amiamoci, / l'unione e l'amore / rivelano ai popoli / le vie del Signore. / [...]Dall'Alpi a Sicilia / dovunque è Legnano, / ogn'uom di Ferruccio / ha il core, ha la mano.”

${ }^{121}$ Italian national anthem, Goffredo Mameli, Il canto degli Italiani (Genoa: 1847). In Italian: "I bimbi d'Italia / si chiaman Balilla, / il suon d'ogni squilla / i Vespri suonò.” These two stanzas are full of references to events in Italian history that glorify Italy's past: the 1176 Battle of Legnano between the army of the Holy Roman Emperor Frederick Barbarossa (1122-90) and the Lombard League; Francesco Ferruccio was a Florentine captain who fought in the Italian Wars of 1494-1559 against France, Spain, the Holy Roman Empire, England, Scotland and the Ottoman Empire; balilla was the nickname given to a Genoese boy who threw a stone to an Austrian official, thus beginning the 1746 Genoese rebellion against the Habsburg army which occupied the city; Vespers referred to the 1282 Sicilian insurrection against French invaders.

122 Benedetto Croce became anti-fascist in 1925, one year after socialist and deputy to the Italian government Giacomo Matteotti (1885-1924) was murdered. In the same year, he also broke his friendship with Giovanni Gentile. Benedetto Croce, Pagine Sulla Guerra (Bari: Laterza, 1928); Benedetto Croce, Storia d'Italia 1871-1915 (Milano: Adelphi, 1991 [orig1928]); Benedetto Croce, Teoria e Storia Della Storiografia (Bari: Laterza, 1943 [orig 1920]).. 
"moral regeneration". He underlined the "civic function" of literature and presented Italian history as the history of its makers, the literate founding fathers. From his work we learn that Machiavelli influenced literate men of the late nineteenth century. He became the forerunner of the canons valued in those years: individual autonomy, fatherland, nationality, liberty, equality, virility, work, and seriousness. ${ }^{123}$ De Sanctis'message to Italian disciples was clear: Italians had fallen in a state of 'sleep'- the dolce far nientewhen weakness replaced the spirit of initiative and self-sacrifice, patriotism and discipline. ${ }^{124}$ The authors who wrote on character in the 1860 s and 1870 s agreed that the moral question was the most urgent they had to address. As historian/scholar Emilio Gentile has observed, "after political unification, the reform of the character of the Italians was the biggest enterprise facing the makers of the New Italy."

Reform had to overturn the "negative myth" of the corrupted Italian character which centuries of foreign domination had fossilized. Until then, efforts to recast the Italian old lineage of glory through masculinizing wars had failed. The discussion on Italianità grew in the years 1860 s and 1870 s to incorporate the political conflict between liberal visions and issues of governance and hegemony, which later on Antonio Gramsci

\footnotetext{
${ }^{123}$ Not all intellectuals were successful in changing the Italians mindset, Machiavelli's counterhero was Francesco Guicciardini (1483-1540). Guicciardini represented a weak and corrupt generation. While he was as ambitious as Machiavelli, he lacked Machiavelli's will and as such failed where Machiavelli succeeded.

${ }^{124}$ Francesco De Sanctis, Storia della letteratura italiana (Milan: Rizzoli, 1983 [orig 18701871]).

${ }^{125}$ Emilio Gentile, La grande Italia. Il mito della nazione nel ventesimo secolo (Roma e Bari: Laterza Editori, 2006), 38; 186.
} 
would interpret as a fight over actual leadership in the new liberal polity. ${ }^{126}$ The values of the liberal élites remained different from those of the majority of people, yet even if they dominated the state apparatus, they believed they needed to understand and educate people to control them. During the 1860s and 1870s, the Italian character became the object of political discourse and of entire tracts devoted exclusively to its description and analysis. Historian Bruno Tobia describes this type of communication as "patriotic pedagogy." $" 127$ Scholar Homi Bhabha refers to the cultural construction of nationness as an act by which the exercise of power may be both more politically effective and psychically affective, because the élite's discursive "liminality" may provide greater scope for strategic maneuver and negotiation. ${ }^{128}$ It is here, between these borderlines that we can see how the Italian people came to be constructed within a range of discourses that formed the story of Italy's master narrative. ${ }^{129}$

When the Italian statesman Massimo d'Azeglio's (1798-1866) pronounced the much-quoted assertion "Now that Italy is made, we must make the Italians", contemporary mainstream interpretation assumed he proposed to convert Italians into

\footnotetext{
${ }^{126}$ Antonio Gramsci, Selections from the Prison Notebooks, <eds> Hoare, Q., Nowell Smith, G. (New York: International Publishers, 1995), 58-59.

${ }^{127}$ Bruno Tobia, Una Patria per Gli Italiani. Spazi, Itinerari, Monumenti Nell'Italia Unita (18701900) (Rome-Bari: Laterza, 1991), viii.

${ }^{128}$ Liminality is an anthropological term used to describe the uncertainties occurring in human transitional stages. It is used to talk about rituals, immigration, or in circumstances when the structuring of identity is in play. Bhabha uses this term extensively in his work.
}

${ }^{129}$ Homi Bhabha, Nation and Narration (London and New York: Routledge, 1990), 297. 
culturally homogeneous individuals. ${ }^{130}$ Other interpretations, however, suggested a different meaning. I believe that likely, D'Azeglio felt the necessity to regenerate the people's moral and civic attitudes, because that was the central issue that other intellectuals like him believed in the years when he penned his words. Antonio Reale had already written in 1878 that d'Azeglio had made it clear that since Italians already existed from earlier times as a race, they needed to be transformed into free citizens of a free state. ${ }^{131}$ D'Azeglio's initiative contributed to the creation of Italianità.

The new government would succeed if its citizens became virtuous, good workers, educated, and committed to their new country. According to the English literary critic Stefan Collini, character was "the favored explanatory element in the analysis of different human fates just as national character enjoyed a special status in accounting for the variety of historical outcomes on a larger scale." ${ }^{\prime 132}$ In this vein, Smiles's Self-Help with Illustrations of Conduct and Perseverance and Il Carattere became very popular in Italy in this period. ${ }^{133}$ The discourse of character that took shape in Italy in 1860s and 1870s supported representative government, which was considered ideal because it needed, and as such promoted, a higher form of national character. In Smiles' work

\footnotetext{
130 “Pur troppo s'è fatta l'Italia, ma non si fanno gl'Italiani." Published posthumously. Massimo d'Azeglio, I miei ricordi (Firenze: G. Barbèra Editore, 1867), 7.

${ }^{131}$ Antonio Reale, Nazione e famiglia: studio intorno al carattere, (Milan: Tip. Pirola, 1878).

${ }^{132}$ Stefan Collini, "The Idea of Character," in National Character and Public Spirit in Britain and France, 1750-1914, R. Romani (Cambridge: Cambridgen University Press, 2002), 293.

${ }^{133}$ Samuel Smiles, Il Carattere (Florence: Barbera, 1872); Self Help with Illustrations of Conduct and Perseverance (London: J. Murray, 1859); Samuel Smiles, Il carattere (Florence: Barbera, 1872).
} 
women were absent; character was essentially an attribute of the "gentleman,"

embodying the ideal of masculinity that was becoming hegemonic in the latter part of the nineteenth century. In the wake of Smiles' theories, Italian government officials and philanthropists financed a proliferation of texts, civic primers, commentaries, books of manners, and prize contests on the importance of education in forming character. ${ }^{134}$ They embarked on a domestic civilizing mission to eradicate bad habits and dispositions and to instill self-discipline and industriousness among the people in the lower classes. ${ }^{135} \mathrm{~A}$ well-known classic of nineteenth century Italian literature, Carlo Collodi (1826-1890)'s Pinocchio (1883), advanced this idea most clearly as the Fairy tells the undisciplined puppet boy,

Mark my words, my boy, whether rich or poor, human beings are duty-bound to do something in this life. They have to work and keep busy. Woes betide if you let sloth rule you! Sloth is a terrible disease. ${ }^{136}$

\footnotetext{
${ }^{134}$ The Italian educators who actively contributed to this scholarship were Michele Lessona, Carlo Lozzi, Dino Carina, Augusto Alfani, Angelo Mazzoleni, Antonio Reale. See Michele Lessona, Volere è Potere (1868); Carlo Lozzi, Dell'ozio in Italia (Turin: Unione Tipografico-editrice, 1870-71); Angelo Mazzoleni, Il Popolo Italiano. Studi Politici (Milan: Vallardi, 1873); Augusto Alfani, Il Carattere Degli Italiani (Florence: Barbera, 1876).

${ }^{135}$ Luigi Rameri, L'Educazione del Popolo Italiano Alla Vita Morale e Civile (Milan: Zanetti, 1864). See also I. Botteri, Galateo e Galatei. La Creanza e l'Istituzione Della Società Nella Trattatistica Italiana Tra Antico Regime e Stato Liberale (Rome: Bulzoni, 1999); Giacinto Gallenga, Codice Delle Persone Oneste e Civili Ossia Galateo Morale per Ogni Classe di Cittadini (Turin-Naples: Unione Tipografica Editrice, 1871); Gustavo Strafforello, La Sapienza del Popolo Spiegata al Popolo Ossia Proverbi di Tutte le Nazioni (Milan: Editori della Biblioteca Utile, 1868); Trivulzio di Belgiojoso, Osservazioni Sul Presente Stato Dell'Italia e Sul Suo Avvenire.

136 “Ragazzo mio, - disse la Fata - quelli che dicono così finiscono quasi sempre o in carcere o all'ospedale. L'uomo, per tua regola, nasca ricco o povero, è obbligato in questo mondo a far qualcosa, a occuparsi, a lavorare. Guai a lasciarsi prendere dall'ozio! L'ozio è una bruttissima malattia [...]." Carlo Collodi, Le Avventure di Pinocchio (Firenze: Giunti Junior, 1998 [orig 1883]), 161; Carlo Collodi, The Adventures of Pinocchio (Oxford: Oxford University Press, 1996), 92.
} 
Another Italian classic, Edmondo de Amicis' bestseller Cuore, contributed a strong dose of civics to the moral regeneration of the Italic people. ${ }^{137}$ Cuore (Heart) is a text full of metaphors as the title itself suggests. To use Bhabha's theories, its readers were called to act as interpreters of such metaphors and to disseminate the translated texts across cultures, becoming agents in the horizontal, secular space of the crowded spectacle of the modern nation. ${ }^{138}$ The importance of educating Italy's peoples to promote the identity and pride of Italians was clear to the statesmen, who implemented new programs for the formation of patriotic citizens, loyal to the new institutions but also endowed with a sense of personal responsibility and group solidarity. Since 1867, history taught in secondary schools stressed to the new "free generation" that

if Italy in the recent past was servile, weak, despised, Italians themselves were the first of all to blame; because if peoples do not always have the government they desire, they certainly always have the one that they deserve. In this was an educated and regenerated moral sense will inform the opinions and the actions of our youth. ${ }^{139}$

Catholics were interested in youth too. Since 1843 exponents of Catholicism had pointed to the essential role of the Church in providing mandatory moral teachings. ${ }^{140} \mathrm{In}$ contrast, anti-clericals saw the Catholic clergy as a factor of corruption, in some cases

${ }^{137}$ Edmondo De Amicis, Cuore (Milan: Oscar Classici Mondadori, 1991 [orig 1886]).

${ }^{138}$ Homi Bhabha, Nation and Narration (London and New York: Routledge, 1990), 293.

${ }^{139}$ Gianni Di Pietro, Da strumento ideologico a disciplina formativa. I programmi di storia nell'Italia contemporanea (Milan: Mondadori, 1991), 231.

${ }^{140}$ See Vincenzo Gioberti, Del primato morale e civile degli Italiani (Brussels: Meline, 1843). 
extreme, as the writings of Giuseppe Garibaldi in those years made clear. He explained that the "moral and physical inferiority of the Italian race" came mostly from entrusting the education of the youth to the priests. ${ }^{141}$ For contemporary Pasquale Villari, the discussion of whether religion was or was not important missed the point. He argued that Italians did not have any strong feelings about religion. Improving the social conditions of the masses was the crucial issue and it would certainly have more success than addressing religion. The importance of economic reform was also advocated by Cristina di Belgiojoso. ${ }^{142}$ For once, everyone agreed on one aspect: women did not need education. The idea of character was part of a gendered discourse addressing exclusively male citizenry, women remained excluded. ${ }^{143}$ Regenerating Italian minds was accompanied also by a regeneration of Italian bodies. Under Francesco De Sanctis's ministry in 1878, gymnastics became mandatory in all schools, a reform that would be furthered in the following decades. Healthy bodies would be the source not only of physical courage but also of strong character. ${ }^{144}$

${ }^{141}$ Giuseppe Garibaldi, Autobiography (New York: Fertig, 1971 [orig 1889]), 11.

${ }^{142}$ Pasquale Villari, "La Scuola e la Questione Sociale in Italia,” in Nuova Antologia (1872), 197257; Cristina Trivulzio di Belgiojoso, Osservazioni sul presente stato dell'Italia e sul suo avvenire (Milano: Vallardi, 1868).

${ }^{143}$ Ilaria Porciani, "Il Plutarco Femminile," in L'Educazione Delle Donne. Scuole e Modelli di Vita Femminile Nell'Italia Dell'Ottocento, S. Soldani (Milan: Angeli, 1989), 297-317.

${ }^{144}$ Suzanne Stewart-Steinberg, The Pinocchio Effect: On Making Italians, 1860-1920 (Chicago: The University of Chicago, 2008), 139-83. 


\section{Subalterns Find Their Voices}

In the years preceding unification, the Italian South [within the broad idea of 'Southern Europe'] had not provoked much discussion. In some pre-1848 conversations there were proposals for a confederate Italy, to accommodate internal diversities, but the moderates who proposed a confederation could reconcile their position with that of the majority. The federalist Carlo Cattaneo accepted Mazzini's call to unity and even if aware of the many internal regional distinctions, did not hint as to the existence of any internal Italian other (Southern Italians). ${ }^{145}$ Cesare Balbo had outlined the peculiarities of the Piedmontese character in some of his writings and considered Piedmontese people immune to the vices caused by centuries of domination. In his argument he supported those intellectuals who believed that Italians were fundamentally a product of historical experience. Drawing part of his argument from a critical reading of Montesquieu, Balbo noted that natural factors such as climate or race played a subordinate role to history in shaping the virtues and vices of peoples (at least of white peoples). ${ }^{146}$ However, in the post-unification literature, Italian regional differences began to appear. The annexation of the Kingdom of the Two Sicilies in 1860 and the struggle against brigandage in the following years inspired the surge of depictions of Italian Southerners as “Africans," a people who had little in common with the image of "civilized" Northerners. ${ }^{147}$

\footnotetext{
${ }^{145}$ Norberto Bobbio, Una filosofia militante: studi su Carlo Cattaneo (Turin: Einaudi, 1971).

${ }^{146}$ Cesare Balbo, Pensieri ed Esempi, (Florence: Le Monnier, 1844).

${ }^{147}$ In her study of Spain's place in the European imaginary, Morcillo advances that Europe, and Europeanism, were constructed metaphors for modernity, whiteness, and Christian values. See Aurora
} 
Conservative liberals began to debate the "Southern question" in the mid-1870s and articulated the north-south dichotomy. ${ }^{148}$ They argued that as a Southern people, Italians as a whole tended to be lazy, but some Italians were lazier than others. ${ }^{149}$ Writings on Southern brigandage, Neapolitans (a term used to refer to the inhabitants of Italy's Southern regions) were compared to anthropophagi and cannibals, whose ferocity they eclipsed. In these texts, their character resembled "in many respect the most decayed Orientals", or that, in respect to cleanliness, "they were even worse than the dirtier Orientals. ${ }^{" 150}$ Other authors, such as Cristina Trivulzio di Belgiojoso, criticized Tuscans more than Southerners, maintaining that the former were too easily satisfied with dolce far niente (pleasant idleness.) ${ }^{151}$ Even d'Azeglio contributed to a racial evaluation of Italian character. He considered the Piedmontese people immune from servile attitudes and the habit of duplicity, which he believed were the ills that absolute government and latifundia (landed estates) had imposed on the rest of the Italian peoples. Like many of his contemporaries, he committed himself to regenerate Italians by educating them with

Morcillo, “The Orient Within. Women 'in-Between' Under Francoism," in Women in the Middle East and North Africa: Agents of Change, Fatima Sadiqi and Moha Ennaji (New York: Routledge, 2011), 260.

${ }^{148}$ Pasquale Villari, Le Prime Lettere Meridionali (Rome, 1920 [prima edizione 1861]); Pasquale Villari, Le Lettere Meridionali Ed Altri Scritti Sulla Questione Sociale in Italia (Torino, 1885); Leopoldo Franchetti and Sidney Sonnino, La Sicilia Nel 1876 (Firenze: Tipografia di G. Barbera, 1877).

${ }^{149}$ See Angelo Mazzoleni, Il Carattere Nella Vita Italiana (Milano: Galli e Omodei, EditoriLibrai, 1878); Michele Lessona, Volere è Potere (Firenze: G. Barbera, Editore, 1872); Carlo Lozzi, Dell'ozio in Italia (Turin and Naples: Unione Tipografico-Editrice, 1871).

${ }^{150}$ Carlo Lozzi, Dell'ozio in Italia (Turin: Unione Tipografico-editrice, 1870-1), 63-67.

${ }^{151}$ Cristina Trivulzio di Belgiojoso, Osservazioni sul presente stato dell'Italia e sul suo avvenire (Milano: Vallardi, 1868). 


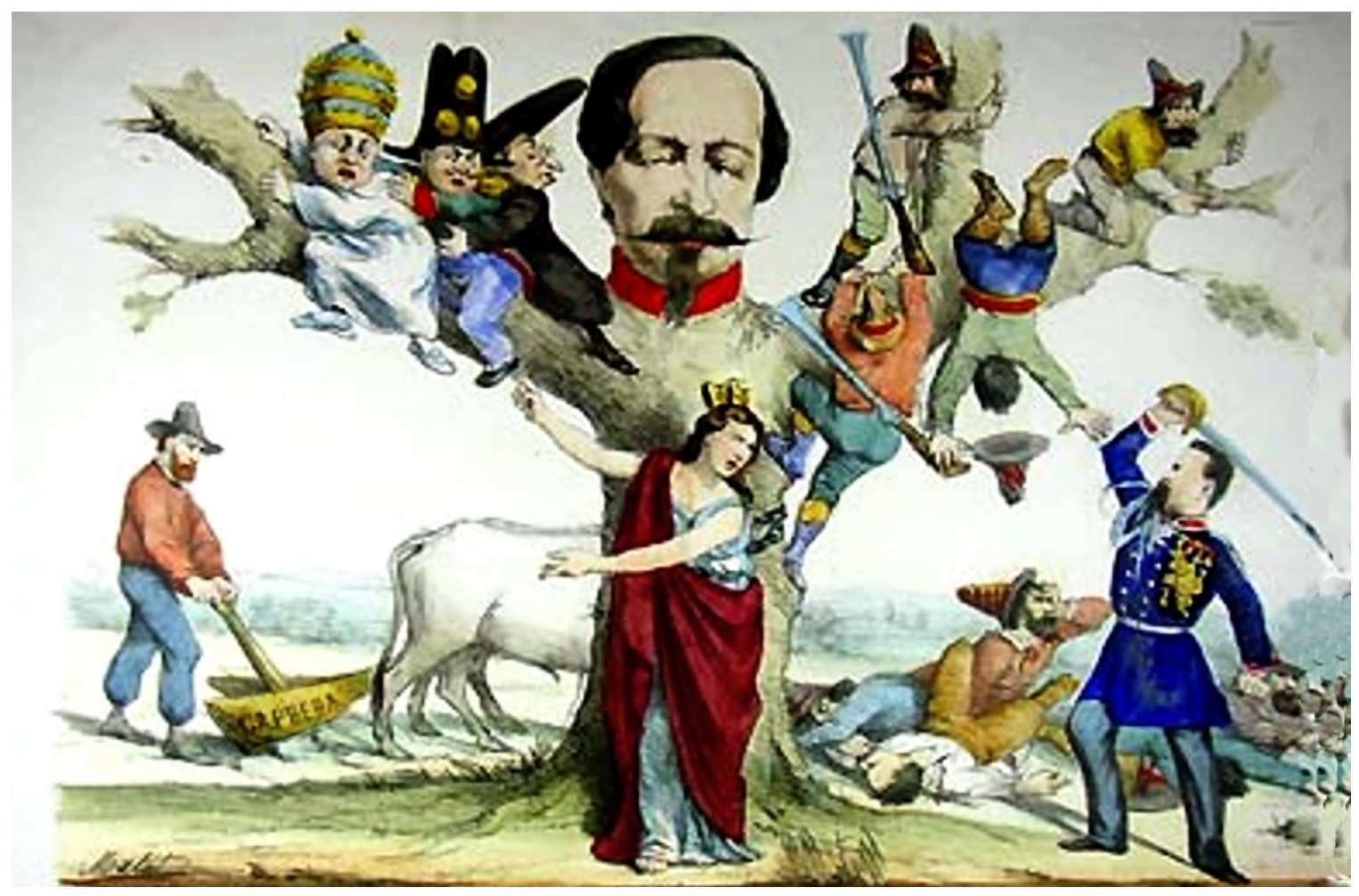

Figure 2. Allegoria dell'Italia post 1861. Print, 1861-1870. Unknown author. Public domain. http://commons.wikimedia.org/wiki/Category: 1860 s political cartoons. ${ }^{152}$

historical novels which narrated the virtues of Italian heroes of the past such as Ettore

Fieramosca. ${ }^{153}$

${ }^{152}$ Allegory of Italy internal political assets, post 1861 and pre 1870 , Napoleon III, Pope Pius IX, Garibaldi as Cincinnatus, brigands, priest and Neapolitan noble as "pazzariello".This allegorical print referred to the Italian political situation in the post-unification period. Italia shows General Enrico Cialdini (1811-1892) (with a drawn sword) his enemies (bandits, Bourbon aristocrats, the clergy, and Pope Pius IX) clinging around Napoleon III (transformed into a tree). Garibaldi is in the background, in Caprera, plowing a field as the aristoCincinnatus. Romans regarded aristocrat Cincinnatus as hero and a model of virtue. The association of Garibaldi with the Roman patrician is meaningful.

${ }^{153}$ Ettore Fieramosca (1476-1515) was a sixteenth-century mercenary who fought to redeem the Italian's honor from the insult of the French invader. See Massimo d'Azeglio, Things I Remember (I miei ricordi), E. R. Vincent (London: Oxford University Press, 1966), 313-5. 
Unfortunately, political reforms were absent from this patriotic pedagogy. These reforms might have contributed effectively to civics education, and formed a large and informed electoral body, with the extension of suffrage. Italy, however, had a very small electoral body, which Italian liberals were reluctant to enlarge. Only in 1882, was the franchise extended from about 6 percent of the adult male population to about 20 percent, more than twenty years after the proclamation of the new Kingdom. A paternalistic conception of power was at the basis of such reluctance: it was not the fear that a larger electorate would benefit subversive political forces on the left or on the right, but the idea that ordinary people did not have the maturity to become full political subjects. Only the élites had the privilege to decide change. This deep-rooted paternalism shows that the class of those people in powerful government positions reflected their suspicions of the pedagogical work of social institutions like the family and schools. Thus, the government remained detached from the world of ordinary people. But things were about to change. During the last years of the nineteenth century the new "cult of the people" that swept Europe reached Italy also.

Intellectuals of the last decades of the 1800s took another view from the classic German philosophy of Idealism to find a solution to the crisis of modern history. Positivism was for them the regenerating doctrine to reconstruct political institutions through the remodeling of opinion and life. Positivists rejected theoretical musings and believed in empirical sciences. They left to philosophers the function of collecting, organizing, and explaining the facts discovered by "positive" sciences. Nature lost its metaphysical dimension. The new scientific reading of natural phenomena was "positive" because these became explicable and amendable by human intervention. In the mid 
1870s, Italian scholars "discovered" Italian peasants and elaborated the social problem that they represented as a consequence of cultural and economic disparities. Italian positivists preferred people to the manipulation of ideas. Their role as intercessors between higher culture and the working classes make their work important for this dissertation. The philosopher Auguste Comte (1798-1857) was the first to propose that Positivism was the regenerating doctrine which could not "do its work without adherents." ${ }^{154}$ Comte was pessimistic about the possibility of finding them in the upper classes in society, even if Positivism was intended for all classes, as they had no interest in social renovation. Comte believed that women and the working classes were the "heartiest supporters" and "the powerful patrons" who could force the higher ranks to take notice of Positivism. ${ }^{155}$

The development of scientific folklore, which investigated the lives and experiences of the working classes (almost 80 percent of Italian society in the nineteenth century), was born out of the new philosophical trend. As positivist intellectuals, Italian folklorists studied the social lives of the working classes and peasants as a natural science. ${ }^{156}$ By taking interest in these people and studying them, these scholars prepared a

${ }^{154}$ Auguste Comte, A General View of Positivism, (London: Routledge \& Sons, 1907), 1-7.

${ }^{155}$ Auguste Comte, A General View of Positivism, (London: Routledge \& Sons, 1907), 1-7.

156 The social composition of the people living in the Italian peninsula in 1800 and before unification comprised farmers (55-60\%); workers in the manufacturing sectors (18\% in the South and $15 \%$ in the North); workers in trade and navigation (mostly in the Reign of the Two Sicilies, 20\%); professionals, clergy, and privileged categories (10\%). See Nicola Zitara, "La gran cuccagna dei fratelli d'Italia" in Il sud e l'unità d'Italia, Due Sicilie, Giuseppe Ressa (Napoli e Palermo: Centro Culturale e di Studi Storici, 2004). 
new class of hearty supporters of positivism, which for them was synonymous with regeneration. ${ }^{157}$ By so doing, they introduced "subalterns" to modernity for the first time. However, not all Italian folklore scholars of the time acted as if this was their genuine and exclusive goal. ${ }^{158}$ The majority of them belonged to a privileged group of aristocratic intellectuals for whom subalterns populated a world to explore and to bring to civilization. ${ }^{159}$ The concept of cultural hegemony proposed by the historian and Marxist intellectual Antonio Gramsci (1891-1937) influences this reading. In his prison notebooks, compiled during his eleven years of captivity from 1926 to 1937 under the Fascist regime, he wrote that unifying Italy required creating a national culture, and theorized that only "progressive" folklore could mend the fracture between high culture and popular culture. He anticipated the risk of cultural hegemony - the presence of a ruling class that used intellectuals to consolidate power. ${ }^{160}$

${ }^{157}$ Auguste Comte, A General View of Positivism, (London: Routledge \& Sons, 1907), 3.

${ }^{158}$ George R. Saunders, "CCritical Ethnocentrism' and the Ethnology of Ernesto De Martino," American Anthropologist, New Series 95, no. 4 (1993): 875; Benedetto Croce, "Poesia 'Popolare' e Poesia 'd'Arte': Considerazioni Teorico-Storiche," La Critica. Rivista di letteratura, storia e filosofia 27 (1929): 321-428.

${ }^{159}$ Niccolò Tommaseo (1802-1874), linguist, journalist, essayist ; Count Angelo de Gubernatis (1840-1913), philologist; Costantino Nigra (1828-1907), diplomat; Giuseppe Pitrè (1841-1916), medical doctor, author of Biblioteca delle tradizioni popolari siciliane; Canti popolari siciliani (1870-1871), and cofounder of the first Italian folklore journal, L'Archivio per lo studio delle tradizioni popolari; Raffaele Corso (1885-1965), anthropologist; Giuseppe Cocchiara (1904-65), anthropologist, author of Storia degli studi delle tradizioni popolari in Italia (1947), and Paolo Toschi (1893-1974), philologist and historian. Pitrè established the first folk museum in Sicily in 1910. See also Ermanno Francis Gizzarelli, "An Historical Survey of Italian Folk Song and a Critical Estimate of Modern Research" (Ph.D. diss., New York: Cornell University, 1938).

${ }^{160}$ I agree with Gramsci's position on folklore: folklore should be studied as "[...] conception of the world and of life," implicit in large measure in certain strata of society, as opposed to "'official" conceptions of the world as these have happened during historical development." The term "progressive" folklore is used in juxtaposition to the folkloric science that is commonly associated with the discovery of 
I argue that the majority of the Italian folklore scholars working at the turn of the nineteenth century were the instruments of cultural hegemony, and yet they allowed the "eruption into history of a class that in many ways really has in the past been outside of it". ${ }^{161}$ They approached new worlds and collected materials according to taxonomic criteria. ${ }^{162}$ They researched origin, time and place of narratives, and their variants and analogues in other languages. The folklorist Paolo Toschi (1893-1974), for instance, instructed fieldworkers to use pre-planned questionnaires with sample questions, and gave specific instructions on how to transcribe dialect. ${ }^{163}$ As explorers, through this erudite rigor, they collected materials which became specimens to display in a museum, or in a book or encyclopedia, deepening their understanding of subalterns. For the first time in the second half of the nineteenth century, the unearthing of people's voices was no longer fortuitous and fragmented, but methodical and, in many instances, exhaustive. These voices were artifacts, folksongs, and folktales. This section will examine the folksong Donna Lombarda and, through the interpretation that one positivist scholar

an archaic world of superstition and prejudice. See George R. Saunders, "“Critical Ethnocentrism' and the Ethnology of Ernesto De Martino," American Anthropologist, New Series 95, no. 4 (1993): 880-1.

${ }^{161}$ George R. Saunders, “'Critical Ethnocentrism' and the Ethnology of Ernesto De Martino,” American Anthropologist, New Series 95, no. 4 (1993): 880-1.

${ }^{162}$ I use the term "taxonomy" in its general, and not biological meaning, to indicate the practice of classification of things or concepts.

${ }^{163}$ Paolo Toschi, Guida allo studio delle tradizioni popolari, (Roma: 1945 [2nd ed.]). In one of Toschi's questionnaires on marriage, the fieldworker was required to find out the time of the year and the day of the week most frequently chosen for the celebration; whether the flowers used in the decorations were real or made out of other materials; what kind of accessories the bride wore and where food was eaten. Fifty-six more questions addressed proverbs relating to marriage and other customs. 
offered, it will attempt to discover how peasants and the working classes understood their world in the period of this study.

\section{One Nation and Two Primedonne: Donna Turrita and Donna Lombarda}

The present section will examine the folksong Donna Lombarda and, through the interpretation that one positivist scholar offered, it will attempt to reveal how peasants and the working classes understood their world in the period of my study. One of the oldest narratives in the Italian imaginary is that of Rosemund, the inspiration of the ballad of Donna Lombarda

Love me,

Oh! that I am nothing otherwise.

Oh! I cannot love you,

I have a husband,

Your husband, donna Lombarda

Must die,

I will teach you how to do it. ${ }^{164}$

It is a story about adultery and conquest and its significance to the construction of

Italianità lies in the fact that Rosemund was a woman, a queen, and the descendant of a tribe, the Gepids, who had invaded the Italic peninsula in the sixth century AD. In the eighth century, the Lombard historian Paul the Deacon (720-799) told the story of the adulterous queen Rosemund. She was the descendant of the Germanic Gepid tribe, and murdered her two Lombard husbands, King Alboin (530-72) and Helmichis (572-?). ${ }^{165}$

\footnotetext{
${ }^{164}$ In Italian "Amami me che sono re / non posso amarti tengo marì / Tuo marito fallo morire / t'insegnerò come devi far / [...], Donna Lombarda, folksong.

165 also Helmegis or Hilmegis.
} 
Paul the Deacon had learned about Rosemund from Secundus of Non (612), Bishop of Trent, and from seventh century chronicles, the Iornandes. ${ }^{166}$ Through the centuries in Northern Italy, which the Lombards had invaded in 568, Rosemund's story inspired similar versions of a ballad, Donna Lombarda. The popular ballad Donna Lombarda is an important source for several reasons. First, it offers a foundation to understand the modalities that have made it possible for a text written in Latin to capture the popular imaginary through the centuries. Second, the ballad illustrates variants in the different accounts. Each has peculiarities to suggest the type of mentality that originated them. Third, Costantino Nigra's observations on the peasants' world offer a ready-made glimpse into the lives of the people that inhabited this world. The ethnographer and folklorist Count Costantino Nigra (1828-1907) collected these songs in his work Canti popolari del Piemonte, published in $1888 .{ }^{167}$ All the interpretations that he found of Donna Lombarda referred to Rosemund's murder of Helmichis, her second husband and her accomplice in the regicide of Alboin. In this episode, the queen, corrupted by her new lover and conspirator Longinus, offered Helmichis a poisoned drink. The text of the folksong was handed down orally through the centuries with few variations from Paul the Deacon's eighth century rendition.

\footnotetext{
${ }^{166}$ Secundus di Non, Historia Langobardorum. Secundus of Non (died $612 \mathrm{ca}$.) was at the court of Agilulf (590-616 AD), king of the Lombards from 591 to his death. See also the anonymous Origo gentis Langobardorum, seventh century manuscript on the founding myth of the Lombards line, probably written during the reign of Rothari, king of the Lombards from 636 to 652.

${ }^{167}$ Costantino Nigra, Canzoni del Piemonte: Donna Lombarda, Rivista Contemporanea (Turin: Tipografia economica diretta da Barera, 1888), 20.
} 
How the exchange between Paul the Deacon's text and the oral nineteenth century

folksong Donna Lombarda took place, can only be inferred. Here is how Nigra referred

Paul the Deacon's version of Rosemund's story

Then prefect Longinus tempted Rosmonda into killing Helmichis and marrying him. Then, since she was known for every iniquity, eager to be mistress of Ravenna, [she] allowed committing such a crime. And to Helmichis, coming out of the bath, a cup of poison, she offered. It felt like he had been drinking death, unsheathed his sword, and forced Rosmonda to swallow the rest. And so, for the judgment of God Almighty, the killers most wicked perished at the same time. ${ }^{168}$

And here is how Nigra commented Paul the Deacon's text

The above mentioned excerpt from the chronicle by Paul the Deacon adheres so much to the popular song, not only in its content but also in its form, that you can with some reason suspect that Paul the Deacon was influenced by a traditional [popular] song not dissimilar from ours when describing the death of Rosemund. It is known in fact, that during the compilation of his chronicle, Paul the Deacon not only used Secundus of Non's work and the work of other chroniclers of the Middle Ages, but also drew extensively [...] from traditions and folk songs. ${ }^{169}$

\footnotetext{
${ }^{168}$ Paul the Deacon, quoted in Costantino Nigra, Canzoni del Piemonte: Donna Lombarda, Rivista Contemporanea (Turin: Tipografia economica diretta da Barera, 1888), 18. Italian text: "[...] Allora Longinus prefetto prese a tentare Rosmonda perchè uccidesse Helmichis e con lui si maritasse. Quella, siccom'era facile ad ogni nequizia, bramosa di farsi signora dei Ravennati, consentì a commettere un tanto delitto. E ad Helmichis, uscente dal bagno, una coppa di veleno, che asseverava ottimo alla salute, propinò. Esso, come sentì d'aver bevuto la morte, snudata la spada, costrinse Rosmonda ad ingoiare il rimanente. E così, per giudizio di Dio onnipotente, gli uccisori scelleratissimi ad un tempo perirono."

${ }^{169}$ Costantino Nigra, Canzoni del Piemonte: Donna Lombarda, Rivista Contemporanea (Turin: Tipografia economica diretta da Barera, 1888), 70. " [...] Il passo sovracitato della cronaca di Paolo Diacono concorda talmente colla canzone popolare, non solo nella sostanza, ma anche nella forma, che si puo` sospettare con qualche ragione che il Diacono nel descrivere la morte di Rosmnda subisse l'impressione d'un canto tradizionale [popolare] non dissimile dal nostro. Si sa difatti che Paolo diacono, nella compilazione della sua cronaca si giovo 'in alcuna parte delle storie ch'egli ha potuto consultare non solo di Secondo vescovo di Trento, ma anche ad esempio di Iornandes e d'altri cronisti del medio-evo, attinse pure ampiamente [...] alle tradizioni e ai canti popolari."
} 
Nigra's comment supports my argument that Paul the Deacon was a cultural intermediary between groups. As in the case of the Italian intellectuals in the nineteenth century, he was an agent of cultural hegemony. Nonetheless it is also through his work that we can reach craftsmen and peasants of modern Italy. As Peter Burke proposed in his 1978 study on popular culture, the possibility of propaganda should always be in mind when studying an historical period when not all the voices have been preserved. ${ }^{170}$ So, in the eighth century, Paul the Deacon collected seventh century texts, the literary one transmitted by Secundus and the popular chronicles collected in the Iornandes, to create his version of a sixth century historical episode that shared analogies with the events that he was witnessing in his era. We know that Paul the Deacon, who probably was secretary to the Lombard king Desiderius (d. 786) and certainly mentor of Desiderius' daughter, Adelperga, had a personal involvement with Lombard royalty and an interest in the creation of a propagandistic narration of this dynasty. As a monk, he also had contact with peasants and the working peoples, and knew the Catholic misogynist rhetoric of sin. Therefore, he was familiar with the common tradition of his day and at the same time he was also a protagonist within the great tradition. He acted as the sophisticated mediator between high and popular culture. ${ }^{171}$ 1978), 72 .

${ }^{170}$ Peter Burke, Popular Culture in Early Modern Europe (New York: Harper\&Row Publishers,

${ }^{171}$ In $770 \mathrm{AD}$, Charlemagne (742-814), founder of the Carolingian Empire, married Desiderius' daughter Desiderata (sister to Adelperga), whom he later repudiated. This probably led to the war between the Franks and the Lombards, who were defeated in 774. After the conquest of the kingdom of the Lombards, Charlemagne took also the title rex Longobardorum (king of the Lombards). 
Italian anthropologists and scholars of the late nineteenth century used what Burke called "alien eyes" to tell us what they saw, or imagined, of the folk. ${ }^{172}$ They picked up the baton as mediators between the medieval craftsmen and peasants and those of the newly born Italy. As in Nigra's case, the crowd of Italian ethnographers and anthropologists writing about "the people" were intellectuals "organically" produced by the leading class. ${ }^{173}$ Folklorists claimed to have collected "popular" artifacts, but it was clear that the majority of the texts and documents they gathered lacked an exclusive popular origin. As long as performances and texts were popular, they argued, little counted if the authorship was not determined. Such positivist paradigms silenced the romantic polemic of the previous century over pure and artificial poetry and the philological diatribe over the origin of texts and genres. It should also silence contemporary debate on the value of accounts "adjusted" by the chronicler, because what folklorists wrote about peasantry and gave voice to these people. Along these lines, the text of the ballad Donna Lombarda sung in the late 1800s is an important subject for the analysis of popular identity. Daily routines reflect people's lives and habits and transmit

\footnotetext{
${ }^{172}$ Burke wrote that to study the history of the illiterate was necessarily to see that history through two pairs of "alien eyes", which belonged to the 'mediator' between the past and us. Peter Burke, Popular Culture in Early Modern Europe (New York: Harper \& Row Publishers, 1978), 68.

${ }^{173}$ See Alberto Ciresi, La poesia popolare (Palermo: Palumbo Editore (1925), 55-7. The concept of "organic intellectual" is, once again, borrowed from Antonio Gramsci. Gramsci described two types of intellectuals: traditional and organic. Traditional intellectuals were the clergy, for instance, or the men of letters, and the philosophers. Gramsci argued that they gave themselves an aura of historical continuity even in presence of political chaos; they thought of themselves as independent of the ruling élite, but this was an illusion. Gramsci saw them as allied to the ruling groups. Then, according to Gramsci, there were the organic intellectuals, who grew organically with the ruling class and represented the ruling groups' thinking element. The ruling élite formed them through the educational system to perform at their service and helped them to maintain hegemony over all social classes. See Antonio Gramsci, "Quaderni del Carcere," V. Gerratana (Turin: Einaudi, 1934), 1514.
} 
messages about the culture in which they lived. They form a symbolic system to evaluate the iconography evoked by the lyrics of the song and the comparison of its variations from Paul the Deacon's literary text, as they arise from Nigra's reading.

The first difference acknowledged by Nigra among the various nineteenth century versions of the ballad refers to the use of the title "king" ("holy crown" in versions from Brescia, Rome, Lucca, and Florence; in Benevento, it becomes king of Spain; in another Roman account, "king" becomes knight), while in a type migrated to France, it converts to a democratic amant (lover). ${ }^{174}$ The wording used in the different ballads states popular self-perception: they were subjects to a sovereign anointed of [Catholic] sanctity in Central Italy (seat of the Papal State); subalterns to a foreign authority in South Italy (ruled by the Bourbons); inferiors to a bourgeois ruler in the version migrated to France. People in Parma, Basso Monferrato, Pontelagoscuro, Venice, Verona, Lucca, Mugello, and Viterbo sang about the king of France (France controlled, with Austria, most of these regions.) ${ }^{175}$ The shaping of Italian identity among the popular classes was already rigidly regionalized. Nigra noted how in these popular renditions the title was attributed both to the husband and to Rosemund's lover and added

\footnotetext{
${ }^{174}$ Costantino Nigra, Canzoni del Piemonte: Donna Lombarda, Rivista Contemporanea (Turin: Tipografia economica diretta da Barera, 1888), 20.

${ }^{175}$ Costantino Nigra, Canzoni del Piemonte: Donna Lombarda, Rivista Contemporanea (Turin: Tipografia economica diretta da Barera, 1888), 20.
} 
in terms of royalty, the folk poetry collection of our time only knows the king of France, Spain, and England. But the king most often mentioned is the king of France. [...] From these various lessons you may get the impression that the idea of characters coated in royal dignity has passed on. ${ }^{176}$

More illuminating is his footnote

With regard to the frequent mention of kings and the king's children in folk songs, folklorist V. Smith (1826-82) refers the response of one of its singers, which is worthy of note: 'As I asked one of the singers, why, instead of her lover, she said king Louis, she answered: - We are used to put kings in our songs, because they make the songs more brilliant.' 177

From the popular belief that kings made their songs more brilliant we can infer the

peasants' mentality in the period of Italy's nation-formation, and maybe also understand the Italian intellectuals' efforts to create a shared identity and a sentiment of belonging to one nation. The particulars of how the poisonous drink was prepared were important for Nigra, and so are for us.

\footnotetext{
${ }^{176}$ Costantino Nigra, Canzoni del Piemonte: Donna Lombarda, Rivista Contemporanea (Turin: Tipografia economica diretta da Barera, 1888), 20.

${ }^{177}$ Victor Smith collected folksongs in the French region of Velay and the Forez in the 1880s. See Victor Smith, Vieilles Chansons Recueillies en Velay et en Forez (Nogent-le-Rotrou: G. Daupeley, 1878). In Costantino Nigra, Canzoni del Piemonte: Donna Lombarda, Rivista Contemporanea (Turin: Tipografia economica diretta da Barera, 1888), 20. In Italian in the text: "In fatto di re, la poesia popolare raccolta ai nostri tempi, non conosce guari che i re di Francia, Spagna, e d'Inghilterra. Però il re più spesso nominato è il re di Francia. [...] Da queste varie lezioni si puo' ricavare l'impressione che nella mente dei cantori popolari si trasmise l'idea, divenuta di generazione in generazione più oscura e incerta, di personaggi rivestiti di regia o quasi regia dignita." And "A proposito della frequente menzione di re e di figli di re nei canti popolari, V. Smith riferisce la risposta d'una delle sue cantatrice, che è degna di nota: ' Comme je demadais (dice lo Smith) à l'une des chanteuses, pourquoi, au lieu de son cher amant, elle disait le roi Louis, elle me répondit: - Nous avons l'habitude de mettre les rois dans les chansons, ca les rend plus brillantes - 'Vict. Smith. Vieilles chansons recueillies en Velay et en Forez. Romania VII."
} 
Oh! how do you want me

to kill him, kill him.

In the garden behind the house,

there is a snake, is a snake.

Cut the head, and then crush it,

Crush it, crush well;

and then put it in red wine;

Give him to drink, give him to drink

These information were absent in Paul the Deacon's text. Our intermediary, Nigra, explained that "folk poetry, as opposed to historical accounts, loves minute, pointless details, but overlooks essential facts." ${ }^{178}$ For Nigra, the popular poet knew, and if he did not, he imagined, that the wine in which a snake's crushed head is diluted could be a deadly drink and that the idea of a poison obtained in such a way was so natural, that poisoning by using snakes included in beverages and food became a commonplace of popular poetry of various countries. The folk medicinal practices of cutting, crushing, mixing, and drinking ingredients, with an intended effect on human body, can be read as an ethno-medical inquiry into the world of the peasantry that allows the interpretation of bodily experience as the embodiment of ideology, discourse, accommodation, resistance,

\footnotetext{
${ }^{178}$ Costantino Nigra, Canzoni del Piemonte: Donna Lombarda, Rivista Contemporanea (Turin: Tipografia economica diretta da Barera, 1888), 20-1. Non vi è concordanza nella preparazione del venefizio che è minutamente raccontata nella canzone e invece omessa nella cronaca. Questa, anziché una differenza, è un'aggiunta della canzone. L'esempio è frequente. La poesia popolare, al contrario della storia, ama certi minuti particolari, spesso oziosi, vi si ferma e vi si compiace, mentre poi pretermette momenti essenziali, o rapidamente li tocca. Come Rosmunda e il suo complice abbiano preparato il veleno, la storia non lo sa. Ma il poeta popolare lo sa, e se non lo sa, lo immagina. È molto dubbio se il vino in cui siasi diluita la testa pestata d'un serpente sia una bevanda micidiale. Ma l'idea del veleno suggerisce quella del serpente in modo cosi naturale, che gli avvelenamenti con serpenti distillati nella bevanda, o dati in cibo, divennero un vero luogo comune della poesia popolare dei varii paesi.
} 
healing and curing. ${ }^{179}$ Psychologists Hood and Williamson documented the existence of a medieval coin on which the crucified Christ appeared on one side and a serpent-entwined cross on the other. They proposed that the crucified Christ was shown as both man and serpent; hence death and resurrection were linked with a reptile. ${ }^{180}$ Thus the serpent has been connected with birth, death—two human events—and resurrection, a miraculous experience. As powerful symbols of religious and secular power, and mythical representations of nature, serpents became object of rituals practiced to exorcize folks' dependency from precariousness and subordination. Finding, handling, cutting the head of a snake, and then crushing it constituted a gratifying ceremony, a sort of class revanchism. Peasants' control over the elements of nature that they knew well, such as serpents and other animals in the popular lore, hint at resilient elements of a popular, animist religion that survived in the Italian semi-feudal world, hidden to the dominant, dogmatic Catholicism of the day.

Further insights into the world of the peasants and working people derive from Nigra's observation on their routines. Helmichis, the husband, drank the poisonous drink proffered by Rosemund after the bath he took upon his return from hunting. In Paul the Deacon's account: “And to Helmichis, coming out of the bath, a cup of poison, she

\footnotetext{
${ }^{179}$ Mark Nichter, Anthropological Approaches to the Study of Ethnomedicine (Amsterdam: OPA Gordon and Breach Science Publishers, 1992).

${ }^{180}$ See Ralph W. Hood and William Paul Williamson, Them That Believe: The Power and Meaning of the Christian Serpent-Handling Tradition (Berkley and Los Angeles: University of California Press), 99.
} 
offered." ${ }^{181}$ In the popular account, as Nigra zealously refers, Rosemund offered the poison drink at Helmichis's return from hunting

Love me Love me me, me love me, love me me.

Oh! I cannot love you, I have a husband, I have the husband?

Your husband, donna Lombarda

Make him die, Make him die.

Oh! how do you want me

to kill him, kill him.

In the garden behind the house, there is a snake, is a snake.

Cut the head, and then crush it, Crush it, crush well; and then put it in red wine;

Give him to drink, give him to drink:

'Cause your husband comes from hunting so thirsty, so thirsty.

Give me wine, donna Lombarda;

I'm so thirsty, I'm so thirsty. ${ }^{182}$

Nigra noted that for the people of the lower classes the concept of bathing after hunting was not as important as that of drinking

${ }^{181}$ Costantino Nigra, Canzoni del Piemonte: Donna Lombarda, Rivista Contemporanea (Turin: Tipografia economica diretta da Barera, 1888), 20.

${ }^{182}$ In Italian in the text: "Amatemi Amatemi me, / amatemi me, amatemi me. / Oh! come volete ch'i' faccia, / chè ho il marito, chè ho il marito? / Vostro marito, donna Lombarda, / fatel morire, fatel morire. / Oh! come volete ch'i' faccia / a farlo morire, di farlo morire. / Nel giardino, dietro la casa, / c'è un serpentello, c'è un serpentello. / Pigliatene la testa, e poi pestatela, / pestatela bene, pestatela bene; / e poi mettetela nel vino nero; / dategli a bere, dategli a bere: / chè il vostro marito vien dalla caccia / con tanta sete, con tanta sete. / Datemi vino, donna Lombarda; / ho tanta sete, ho tanta sete.[...]. "Costantino Nigra, Canzoni del Piemonte: Donna Lombarda, Rivista Contemporanea (Turin: Tipografia economica diretta da Barera, 1888), 20-1. 
In the song, the drink is prepared for her husband when he arrives home thirsty and, in many versions, after the hunt. In Paul the Deacon's chronicle, the offer is made to the husband after his bath. [...]. It may seem more natural to the people being thirsty after hunting than after a bath. ${ }^{183}$

Most importantly, Nigra pointed out the fact that the drink was indefinite in the literary texts, but it clearly became wine in the popular renditions. Folklore scholar Owen Jones argued that identities relate to eating practices. ${ }^{184}$ Wine recurs in popular culture, in songs, ballads, and proverbial expressions, as in the saying collected by folklorist Giuseppe Giusti (1809-1850), "Wine is the best comfort during long labors", or in "If I have worries, I stop and ask wine for help. Then I sing and continue to walk with my future in my pocket" by poet Carlo Alberto Salustri, known as Trilussa (1873-1950). ${ }^{185}$

As a natural and accessible product, wine represented the primary component of a hygienic practice based upon diet and a guarantor of strength, energy, and good health. The proverbial expression "Il vino fa buon sangue" shows that wine was approved for those engaged in heavy labor, suggesting the equation of the drink with blood, vigor and

\footnotetext{
${ }^{183}$ Italian text: "Nella canzone la bevanda è preparata al marito per quando entrera" in casa assetato, e secondo molte versioni, dopo la caccia. Nelle cronache invece, gli è offerta all'uscire dal bagno. Le due varianti non sono inconciliabili. Il marito poté entrar nel bagno dopo la caccia. E forse parve più naturale al senso popolare la sete dopo la caccia che dopo il bagno". Costantino Nigra, Canzoni del Piemonte: Donna Lombarda, Rivista Contemporanea (Turin: Tipografia economica diretta da Barera, 1888), 21.

${ }^{184}$ Michael Owen Jones, "Food Choice, Symbolism, and Identity: Bread-and-Butter Issures for Folkloristics and Nutrition Studies," The Journal of American Folklore 120, no. 476 (2005): 145.

185 "Nelle lunghe fatiche della state il migliore conforto ed aiuto è il vino." in Giuseppe Giusti, Dizionario Dei Proverbi Italiani (1852), 110. "Se me frulla un pensiero che me scoccia me fermo a beve e chiedo aiuto ar vino: poi me la canto e seguito er cammino cor destino in saccoccia", in Carlo Alberto Salustri, Acqua e Vino (Roma: Arnoldo Mondadori (Tip. Operaia Romana), 1945. Trilussa was born in the lower Roman social class and chose to never be part of the literary circle.
} 
stamina. ${ }^{186}$ Wine, along with the numerous elements of magic found in folk tales, were other facets that reproduced the image, voices, and beliefs of the lower classes. On a symbolic level, magical thinking was the popular response to difficult conditions of existence in a precarious world. Magic was the product of the "spurious bud, which 'grafted to the primitive text of the song at a time when such miracles multiplied in the popular legends."187

Nigra's use of the iconography proposes further readings of the popular mentality in the late 1800s, regarding justice. Nigra argued "It mattered to the popular poet to insist on the punishment of the treacherous woman ..., because' it responds to a sentiment of justice, which the people ordinarily obey". ${ }^{188}$ Nigra also underlined that the title Donna Lombarda said much about the ethnic group in the Italian peninsula who first sang the story, and about the reason every version of the folksong maintained the appellation of “donna lombarda."189 Since Rosemund was a Gepid, he argued, Lombard peoples colonizing the Po valley in the sixth century would have called her "Gepida," as her ethnic origin suggested. Instead, for Latin peoples, natives of the area, all of the invaders

\footnotetext{
${ }^{186}$ Frances M. Malpezzi and William M. Clements, Italian American Folklore (Little Rock: Augustus House, 1992), 235-6. The translation "wine makes good blood" is not a good rendering of the implied meaning of the Italian proverbial expression and for this I left it in the original language.

${ }^{187}$ Costantino Nigra, Canzoni del Piemonte: Donna Lombarda, Rivista Contemporanea (Turin: Tipografia economica diretta da Barera, 1888), 20-1. “[...]germoglio spurio, che s'innesto' al testo primitive della canzone in un'epoca in cui tali miracoli si moltiplicarono nelle leggende popolari. [...]"

${ }^{188}$ Costantino Nigra, Canzoni del Piemonte: Donna Lombarda, Rivista Contemporanea (Turin: Tipografia economica diretta da Barera, 1888), 23.

${ }^{189}$ Lower case in the original texts.
} 
were "Lombards." For this reason, in the popular consciousness Donna Lombarda had to be, for antonomasia, Rosemund, a Lombard by marriage, an oppressor, and therefore heinous. $^{190}$

\section{Conclusion}

The creation of Italy was the product of historical circumstances, but the new state was built upon uncertain terrain. For the Italian founding fathers, Italians represented the historical certainty and settled nature of the nation, but they were nowhere to be found. Chapter 1 has illustrated the complexity of determining how a group of Mediterranean peoples turned into Italians rather than Spaniards, French, Greeks, or North Africans. Certainly, Italians had a peculiar quality which distinguished them from the rest, but, obviously, it could not be "the inertia,", "the deadly torpor,", or "the atmosphere of negligence and indolence" that according to the early nineteenth century Italian literati enclosed the place and the people. ${ }^{191}$ Many felt embarrassment in mentioning their origin, and some addressed reproachful comments to the clergy, who they held responsible for corruption and for Italy's negative reputation in Europe. ${ }^{192}$ Recent scholarship confirms that the gendered terms used by nineteenth-century intellectuals were the result of a long process of demilitarization of Italian society and that the lack of military ethos in the

\footnotetext{
${ }^{190}$ Costantino Nigra, Canzoni del Piemonte: Donna Lombarda, Rivista Contemporanea (Turin: Tipografia economica diretta da Barera, 1888), 25.

${ }^{191}$ Francesco Venturi, “The Enlightenment in Southern Italy," in Italy and the Enlightenment: Studies in a Cosmopolitan Century, S. Wool (London: Longman, 1972), 209.

${ }^{192}$ Pietro Verri, "Decadenza del Papato, Idea del Governo di Venezia e Degli Italiani in Generale," in Scritti vari, Giulio Carcano (Firenze: Le Monnier, 1854), 57.
} 
nobility and the influence of the Catholic Church were seen as the main roots of indolence and lack of initiative. ${ }^{193}$

While the theme of Italianità focused on what made the people of Italy "Italians" and placed character as central to the discourse in the years preceding Italy's unification, the major exponents of the intellectual and political Italian stage as well as minor figures, discussed what "making Italians" meant. They all addressed Italians' moral and civic attitudes, but disregarded the Italian ethno-cultural identity, which was taken for granted. 194 Nigra, as one of the positivist intellectuals who finally became interested in the Italian ethno-identity in the last decades of the nineteenth century, wrote that to understand the nation, "the diligent investigators of the nation" had to read with attention the content of the "curious document" represented by folk texts. ${ }^{195}$ He was an investigator, but also an instrument of cultural hegemony. He placed a literary, semi-historical account and a folksong in a dialectical relationship to prompt expressions of popular resentment to foreign domination. All his annotations on the text of the folksong provide a reflection upon the lower classes' self-perception, and indicated how they identified vis-à-vis with "invaders." At the same time, it forces us to reflect on gendered approaches to narratives

\footnotetext{
${ }^{193}$ Michael G. Broers, "Noble Romans and Regenerated Citizens: The Morality of Conscription in Napoleonic Italy, 1800-1814," War in History 8 (2001): 249-70; Gregory Hanlon, The Twilight of a Military Tradition: Italian Aristocrats and European Conflicts, 1560-1800 (New York: Holmes and Meier, 1998).

${ }^{194}$ Silvana Patriarca, Italian Vices: Nation and Character from the Risorgimento to the Republic (Cambridge: Cambridge University Press, 2010), 78.

${ }^{195}$ Costantino Nigra, Canzoni del Piemonte: Donna Lombarda, Rivista Contemporanea (Turin: Tipografia economica diretta da Barera, 1888), xi-xxxvii.
} 
of the nation. These narratives were intrinsic to nationalist discourses, and the cultural hegemony implemented by folklorist intellectuals. The presence of Austro-Hungarian troops in the Northeastern parts of the Italian peninsula in the nineteenth century and the early twentieth century, helps explain the determination of Italian intellectuals and leaders to appeal to people against Northern invaders, just as those in the eighth century had already done.

The nineteenth century Italian ruling class utilized culture to forge national discourse by selecting folksongs, such as Donna Lombarda, which had narrated the struggle of the Italic peoples against foreign invaders since time immemorial. At the same time, these intellectuals' texts reflected a system of signs that represented the transcription of the popular voice. In the decades that bridged the nineteenth and twentieth centuries, new issues arose as a consequence of the political choices made by the Italian government. The following chapter explores how the subalterns' voices were redirected within the élites' narratives of these years. 


\section{CHAPTER 2}

\section{THE DEVELOPMENT OF THE CONCEPT OF ITALIANITÀ IN ITALY}

All of Italy south of the Apennines and all of the adjacent islands are occupied by a longheaded, dark, "Mediterranean" race of short stature. This is the South Italian, supposed to be descended from the ancient Ligurians of Italy and closely related to the Iberians of Spain and the Berbers of northern Africa. Indeed, the foremost Italian ethnologist, Sergi, traces their origin to the Hamitic stock [...] of North Africa.

Dillingham Commission (1910)

The geographical distinction of North and South Italy became a racial indicator in the trans-Atlantic movement to North America (with Southern Italian immigrants outnumbering their Northern compatriots after the 1880s) and reinforced the already existing separation between Italians within Italy. ${ }^{196}$ On December 5, 1910, Senator William Dillingham (1843-1923), Chairman of the U.S. Immigration Commission, transmitted to the 61 st U. S. Congress a report entitled Dictionary of Races or Peoples

${ }^{196}$ Cesare Correnti wrote "Era l'Italia una casa nella quale...gli usci per cui s'avrebbe avuto a passare d'una in altra camera, erano più gelosamente sbarrati che non le esteriori porte d'entrata." (Italy was a house where...the doors through which one [the family members] passed from one room to the other were locked more securely than the entrance doors.) . Quoted in Rodolfo Morandi, Storia Della Grande Industria in Italia (Turin: Einaudi, 1966), 34. 
"on behalf of the Immigration Commission." ${ }^{197}$ Cataloging immigrants to the United States by country of birth seemed unsound to the members of the Immigration Commission because, as they clarified in the Dictionary, only in 1899 did the Bureau of Immigration implement "an improved method of recording immigration" and "finally adopted the racial classification." 198 The Commission members explained that the dictionary was "intended primarily as a discussion of the various races and peoples indigenous to the countries furnishing the present immigration movement to the United States, or which may become sources of future immigration. ${ }^{, 199}$ The dictionary was a significant step in the construction of the rationale that formed the basis of the United States restriction laws of the 1920 s. $^{200}$

The introduction of the report made it clear the criteria for the classification of Italian immigrants. The report indicated it was a study intended not for the ethnologist, but for "the student of immigration; for the one who wants in convenient form an approximately correct statement as to the ethnical status of immigrant races or peoples,

\footnotetext{
${ }^{197}$ This report was prepared for the Commission by anthropologist Dr. Daniel Folkmar (1861unknown) assisted by physician Dr. Elnora C. Folkmar (1863-1930). See Letter of Transmittal in William Dillingham, Dictionary of Races or Peoples, Reports, Reports of the Immigration Commission (Washington: U.S. Government Printing Office, 1911).

${ }^{198}$ William Dillingham referred to anthropologist Daniel Folkmar (1861-unknown) and physician Dr. Elnora C. Folkmar (1863-1930). See Letter of Transmittal in William Dillingham, Dictionary of Races or Peoples, Reports, Reports of the Immigration Commission (Washington: U.S. Government Printing Office, 1911), 1.

${ }^{199}$ William Dillingham, Dictionary of Races or Peoples, Reports, Reports of the Immigration Commission (Washington: U.S. Government Printing Office, 1911): 1-2.

${ }^{200}$ The 1921 Emergency Quota Act and National Origins Formula, and the 1924 Immigration Act.
} 
their languages, their numbers, and the countries from which they come.”201 The

government researchers employed anthropologist Johann F. Blumenbach's (1752-1840)

classification of races, "which school geographies have made most familiar to

Americans, viz., the Caucasian, Ethiopian, Mongolian, Malay, and American, or, as

familiarly called, the white, black, yellow, brown, and red races."202 This classification

divided Italians in two groups, North Italian and South Italian. According to the report, they differed from each other "materially in language, physique, and character, as well as in geographical distribution."203 The report informed that

Physically the Italians are anything but a homogeneous race. The Apennine chain of mountains forms a geographical line which corresponds to the boundary between two distinct ethnic groups. The region north of this line, the basin of the Po, is inhabited by a very broad-headed ("Alpine") and tallish race, the North Italian. The inhabitants of the eastern and western halves of this basin show slight variations due to some Teutonic admixture in Lombardy and to an infusion of Slavic blood in Venetia. All of Italy south of the Apennines and all of the adjacent islands are occupied by a longheaded, dark, "Mediterranean" race of short stature. This is the South Italian, supposed to be descended from the ancient Ligurians of Italy and closely related to the Iberians of Spain and the Berbers of northern Africa. Indeed, the foremost Italian ethnologist, Sergi, traces their origin to the Hamitic stock [...] of North Africa.

${ }^{201}$ William Dillingham referred to anthropologist Daniel Folkmar (1861-unknown) and physician Dr. Elnora C. Folkmar (1863-1930). See Letter of Transmittal in William Dillingham, Dictionary of Races or Peoples, Reports, Reports of the Immigration Commission (Washington: U.S. Government Printing Office, 1911), 3.

202 Johann Friedrich Blumenbach (1752-1840) was a German anthropologist, who studied similarities and differences in the anatomy of different organisms. See William Dillingham, Dictionary of Races or Peoples, Reports, Reports of the Immigration Commission (Washington: U.S. Government Printing Office, 1911): 3.

${ }^{203}$ William Dillingham, Dictionary of Races or Peoples, Reports, Reports of the Immigration Commission (Washington: U.S. Government Printing Office, 1911): 81. 
The Italian anthropologist Giuseppe Sergi's (1841-1936) theories on races met the Commission's encoded racial classification systems. Sergi proposed that a classification based on a biological analysis of physical characteristics rather than on cultural and philological aspects of peoples was more reliable. The Commission had heavily drawn also from work by eugenicists Madison Grant (1865-1937) and William Z. Ripley (18671941) who advanced similar assumptions. Yet, Sergi's hypotheses that individuals belonging to the Mediterranean race traced their origin to Hamitic stock of North Africa most certainly appealed to the Commission members, as they mentioned it in the report. For Sergi, the Mediterranean race comprised the Southern inhabitants of the Southern European countries. They were the progeny of Ham, one of Noah's sons, and had created superior civilizations. As such, Sergi believed that the Mediterraneans were the greatest race in the world. The argument that Mediterraneans traced their origins in North Africa, however, was used by Sergi's opponents in Italy claiming the superiority of the Nordic Aryan race, and by nativists in the United States, as the Dillingham Report demonstrates.

It must be remembered that the Hamites are not Negritic or true African, although there may be some traces of an infusion of African blood in this stock in certain communities of Sicily and Sardinia, as well as in northern Africa. The Bureau of Immigration places the North Italian in the "Keltic" division and the South Italian in the "Iberic." Comparatively little admixture has taken place between these two ethnic groups, although many North Italians have found their way around the eastern end of the mountain chain into middle Italy. Therefore, the line of demarcation between the Emilians and the Tuscans is much less sharp than it is between the Piedmontese and the Genoese. ${ }^{204}$

\footnotetext{
${ }^{204}$ William Dillingham, Dictionary of Races or Peoples, Reports, Reports of the Immigration Commission (Washington: U.S. Government Printing Office, 1911): 81.
} 
This language revealed that investigators distinguished between ethnicity, race, and nationhood. The way the Dillingham Commission authors articulated their position and classified groups within races, supports my argument that for the United States' government, objective characteristics such as geography, language, physical, and psychological characteristics were markers of ethnicity that demarcated social categories. These categories determined Italian immigrants' position in the American social hierarchy.

In the years when European intellectuals were at work to create nations according to moral and spiritual principles incorporating an heroic past, great leaders, and glory, immigrants to the United States were predestined to become what the race shown on their immigration documents indicated. ${ }^{205}$

This chapter investigates Italianità in Italy and in the United States from the 1860 s to the 1930 s. It traces narratives on race during these years, and people's

\footnotetext{
${ }^{205}$ From the end of the eighteenth century and to the early decades of the twentieth century, intellectuals debated extensively on nationalism. From Immanuel Kant (1724-1804)'s self-determinism to Ernest Renan's (1823-1892), theories on the spiritual principles nourishing the nation, a whole generation of thinkers speculated on what was a nation and what made peoples citizens of a nation. See Immanuel Kant, Critique of Pure Reason (London: Henry G. Bohn, 1855 [1781 first edition]); Gottlieb Johann Fichte, Contribution to the Rectification of the Public's Judgment of the French Revolution (1793); Gottlieb Johann Fichte, "The Doctrine of the State," in The Doctrine of the State (1813); Gottfried Johann Herder, Treatise on the Origin of Language (Cambridge: Cambridge University Press, 2002 [1772 first edition]); Jean Jacques Rousseau, The Social Contract or the Principles of Political Rights (New York and London: G. P. Putnam's Sons, 1893); Karl Marx and Frederick Engels, Selected Works (London: Lawrence and Wishart, 1951); Emile Durkheim, The Division of Labor in Society (New York: The Free Press, 1997); Max Weber, The Vocation Lectures: Science as a Vocation; Politics as a Vocation (Indianapolis: Hackett Publishing, 2004); Ernest Renan, "What is a Nation?" in Becoming National: A Reader, Becoming national (New York and Oxford: Oxford University Press, 1996).
} 
interpretations of their cultural and regional differences. ${ }^{206}$ The chapter also explores how these interpretations changed with emigration to the Americas in general, and how they affected the Italian enclave in Southeast Florida in particular.

Race and color influenced the experiences of Italians who reached North America. Recent historiography presents color and race as two distinct markers, which deeply structured everyday lives and entitled immigrants to the United States to shares of resources. ${ }^{207}$ Italians were all "white" at arrival, yet their race was different. As historian Thomas Guglielmo wrote, Italians' whiteness was their most prized possession. ${ }^{208}$ The racial classification of Northern or Southern Italian, however, decided Italians' rank as foreign aliens.

${ }^{206}$ Between 1900 and 1920, about five million Italians migrated to the United States and Canada. Commissariato Generale dell'Emigrazione, Annuario Statistico Dell'emigrazione Italiana Dal 1876 al 1925, tech. rept. (Rome, 1926); Sommario di Statistiche Storiche Italiane 1861-1955, tech. rept. (Rome, 1958). See also Daniela Del Boca and Venturini Alessandra, "Italian Migration," paper presented at , Mobility and Flexibility of Labor (IZA) (Bonn, 2003), Http://ftp.iza.org/dp938.pdf

${ }^{207}$ Thomas A. Guglielmo, White on Arrival: Italians, Race, Color, and Power in Chicago, 18901945 Oxford: Oxford University Press, 2003); George Lipsitz, "The Possessive Investment in Whiteness: Racialized Social Democracy and the 'White' Problem in American Studies," American Quarterly 47 (1997): 369-427; Dana Frank, "White Working-Class Women and the Race Question," International Labor and Working-Class History 54 (1998): 80-102; Eric Arnesen, "Whiteness and the Historians' Imagination," International Labor and Working-Class History, no. 60 (2001): 3-32; Peter Kolchin, "Whiteness Studies: The New History of Race in America," Journal of American History 81 (2002): 15473 .

${ }^{208}$ Thomas A. Guglielmo, White on Arrival: Italians, Race, Color, and Power in Chicago, 18901945 Oxford: Oxford University Press, 2003), 9-21. 


\section{White but Divided, 1870-1900}

Geography and not political boundaries attributed status. According to the U. S. government, mountain ranges and river basins shaped the Italian emigrants' physical characteristics, characters and language. Geography was more important than nationality.

Linguistically, Italian is one of the grand divisions of the Romance group of languages descended from the Latin stock of the Aryan family. It has many dialects, the separation and preservation of which is favored by the geographical configuration of Italy. All the upper groups of dialects as defined by Hovelacque, except the Genoese, are North Italian. They contain many Gallic or Celtic elements and show affinities for the Provençal and the Rhieto-Romansh (Ladin and Friulan) languages, which bound them on all sides except the South. The Genoese and the dialects of the central and lower groups are used by South Italians. $^{209}$

As with geography, Italian dialects — and their speakers — were also classified as "high" or "low." From 1899, a new method of recording immigration through racial classification for naturalization applications was implemented, (Declaration of Intention), and was still used until the end of the 1930s. In this, the United States Immigration Bureau admitted that Italians were white, but attributed to North and South Italians different roles in the American society. ${ }^{210}$ I have not found traces of official

\footnotetext{
${ }^{209}$ Abel Hovelacque (1843-1896) was a French linguist and anthropologist. Quoted in William Dillingham, Dictionary of Races or Peoples, Reports, Reports of the Immigration Commission (Washington: U.S. Government Printing Office, 1911): 81-3.

${ }^{210}$ Abel Hovelacque (1843-1896) was a French linguist and anthropologist. Quoted in William Dillingham, Dictionary of Races or Peoples, Reports, Reports of the Immigration Commission (Washington: U.S. Government Printing Office, 1911): 81-3. See also Ronald H. Bayor, The Columbia Documentary History of Race and Ethnicity in America (New York: Columbia University Press, 2004), 626; "Naturalizations," Naturalization Records, Genealogy (Sandpoint, Idaho: Bonner County Recording Office).
} 
objections or disputes from the Italian establishment or people for this differential treatment. Evidently, Italians complied with the US norms because they experienced racial diversity in Italy as well.

Italian immigrants faced their share of racial polarization and othering in their home country, as part and parcel of the Italian founding fathers' rhetoric crafting the nationalist project. ${ }^{211}$ Pre-unification (1830s and 1840s) attempts to resuscitate Italian nationalist sentiment through revolts against foreign invaders, became an obligation after the 1861 unification of Italy. Nationalist leaders planned the construction of a national identity by uniting the many regional diversities. For the first time, they admitted the presence and role of peasants and the working classes in the construction of a shared, communal identity. Consequently, in the decades that bridged the nineteenth and twentieth centuries, the regional diversities forced Italian political leaders to acknowledge the existence of the so-called "Southern question" (la questione meridionale). The "Southern question" dominated the political and economic discourse of the time on both sides of the Atlantic. ${ }^{212}$

\footnotetext{
${ }^{211}$ Writer Pasquale Turiello (1836-1902) argued in 1882 that Italians and the Italian politics and society had both a "Neapolitan character", and embodied typical Italian defects such as excessive individualism and lack of discipline. Turiello held that democracy was not for everyone, and that governments must be adapted to the character and level of civilization of a people. Journalist Antonio Gallenga (1810-1895) in 1886 also addressed Italians with disappointed remarks expressing pessimistic views about Italians' ability to change and conquer a proud Italianità after almost a quarter of century from the achievement of nationhood. In Pasquale Turiello, Governo e governati in Italia. Saggio, (Bologna: Zanichelli, 1882); Antonio Gallenga, L'Italia presente e futura con note di statistica generale, (Florence: Barbera, 1886).

${ }^{212}$ In 1873, Antonio Billia (1831-1873), Deputy in the Italian Parliament, used the term "la questione meridionale" for the first time to describe the disastrous economic situation in the South compared to other regions of the recently unified Italy.
} 
The North-South paradigm informed a debate that was not exclusively Italian. In the last decades of the nineteenth century, three military events contributed to make the category of "Latin nations" a synonym for failure and an object of inquiry for European intellectuals and politicians alike: first, the Kingdom of Prussia defeated the Second French Empire; second, the Ethiopians inflicted a humiliating blow on Italian troops in East Africa; and finally, Spain lost its ultra-marine empire after the Spanish-American War in $1898 .^{213}$

The 1880s and 1890s, brought an overall ideological shift in Europe. Philosopher Herbert Spencer's (1820-1903) theories on "the survival of the fittest," and the prevalent social Darwinist views regarding human development, informed the international debate and influenced international discussions. ${ }^{214}$ French and Italian literati theorized how different races had fixed psychological characteristics which determined their success or failure in the world, and pointed out how Anglo-Saxons owed their independence and

${ }^{213}$ In the War of 1870-1871, the Kingdom of Prussia, aided by the North German Confederation and the South German states of Baden, Württemberg and Bavaria, defeated the Second French Empire, which lost status and geopolitical preeminence in Europe; in 1896, Italy suffered a humiliating defeat at Adowa, at the hands of Ethiopian forces. The Italian presence in Ethiopia was the result of a belief that, once finally united, Italy needed an empire as other European powers, and thus attempted the invasion and control of territories in East Africa; Spain also encountered her downfall the 1898 Spanish-American War, a conflict fought between Spain and the United States over the ongoing Cuban War for Independence.

${ }^{214}$ Herbert Spencer was the first intellectual to propose the economic theory of the "survival of the fittest" that contended that only favored races survived in the struggle for life. This is an elaboration of Charles Darwin's (1809-1882) idea of "natural selection." See Herbert Spencer, The Principles of Biology (London and Edinburgh: Williams and Norgate, 1864); Charles Darwin, The Origin of Species (New York: P. F. Collier \& Son Company, 1909 [1st edition 1859]). 
individualist spirit to their ancestry. ${ }^{215}$ French and Italian learned élites argued that within Europe, Latin societies were especially at risk of miscegenation and feared the rise of new forms of caesarism, i.e. of authoritarian regimes in the hands of political leaders who

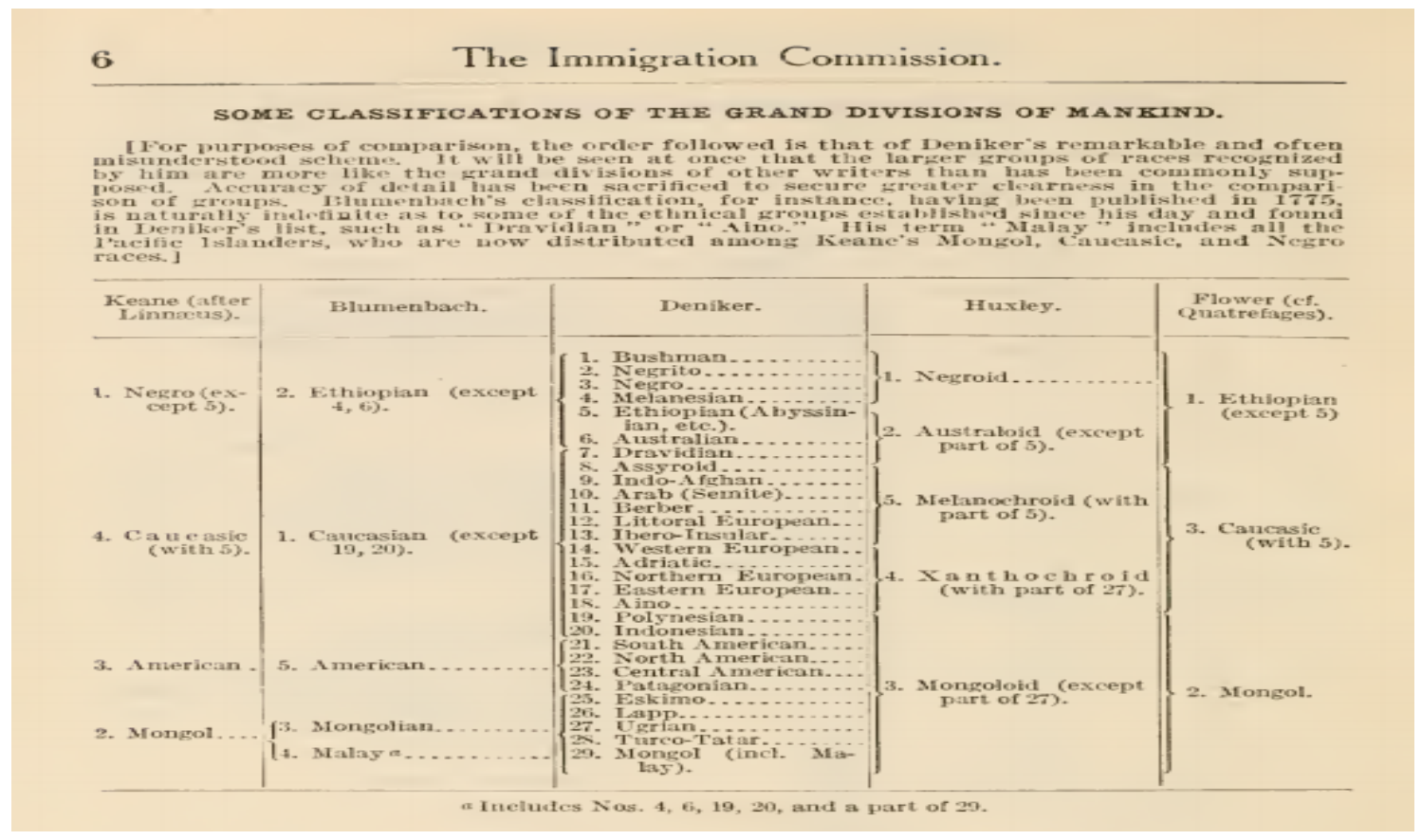

Figure 3: William Dillingham, Dictionary of Races or Peoples, page 6.

${ }^{215}$ Gustave Le Bon, Lois psychologiques de l'evolution des peuples (Paris: Alcan, 1894); Edmonde Demolins, À quoi tient la supériorité des Anglo-Saxons (Paris: Firmin-Didot, 1897); Guglielmo Ferrero, L’Europa giovane. Studi e viaggi nei paesi del nord (Milan: Treves, 1897). 
ment for the twelve vears encling. June :30, 19)10, are shown in the table which follows. Reliable datir repecting the number of rurks and fivians in surope are not available, and consequently these races are ontited. With these exceptions, however, the table inclucles all louropan races or peoples which in the years specified contributed more than 2,000 immigrants to the movement to, the Inited sitates.

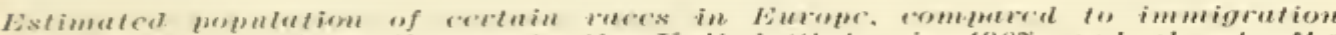

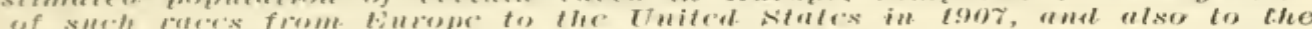

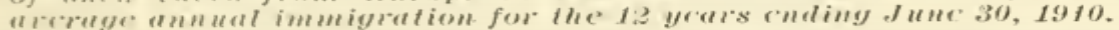

\begin{tabular}{|c|c|c|c|c|c|}
\hline \multirow{3}{*}{ kace or people. } & \multirow{3}{*}{$\begin{array}{l}\text { Estimated } \\
\text { polpulation } \\
\text { in Europe. }\end{array}$} & \multicolumn{4}{|c|}{$\begin{array}{l}\text { Immigrants to the United States from } \\
\text { Europe. }\end{array}$} \\
\hline & & \multirow[b]{2}{*}{$\begin{array}{c}\text { Total } \\
\text { number, } \\
1907\end{array}$} & \multirow{2}{*}{$\begin{array}{c}\text { Average } \\
\text { annual } \\
\text { number, } \\
12 \text { years, } \\
1899-1910 .\end{array}$} & \multicolumn{2}{|c|}{$\begin{array}{l}\text { Number per 1,000 } \\
\text { estimated popu- } \\
\text { lation based on- }\end{array}$} \\
\hline & & & & $\begin{array}{c}\text { Total } \\
\text { number, } \\
\text { 1907. }\end{array}$ & $\begin{array}{c}\text { A verage } \\
\text { annual } \\
\text { number, } \\
12 \text { years, } \\
1899-1910 .\end{array}$ \\
\hline $\begin{array}{l}\text { Slovak. } \\
\text { llebrew }\end{array}$ & 2.250 .000 & 41,870 & 31,272 & 18.6 & 13.9 \\
\hline Croatian and & 8.000 .000 & 146,409 & $\times 4,232$ & 18.3 & 11. 0 \\
\hline $\begin{array}{l}\text { Croatian and } \\
\text { Italian, South }\end{array}$ & 3. 600,000 & 47,317 & 27,704 & 13.1 & 7. 7 \\
\hline $\begin{array}{l}\text { Italian, South } \\
\text { Norwegian } a . .\end{array}$ & 20.000 .000 & 238,469 & 157,300 & 11.9 & 7.9 \\
\hline $\begin{array}{l}\text { Norwegian } a \\
\text { lrish } b . . . . .\end{array}$ & $\begin{array}{l}2,311,000 \\
4,500,000\end{array}$ & $\begin{array}{l}22 \\
37.0413 \\
\end{array}$ & $\begin{array}{l}17,204 \\
35,086\end{array}$ & $\begin{array}{l}9.5 \\
8.4\end{array}$ & 7.4 \\
\hline $\begin{array}{l}\text { Mrish b.... } \\
\text { Polish ... }\end{array}$ & $17.000,000$ & 137.147 & 78.528 & $\begin{array}{l}8.4 \\
8.1\end{array}$ & $\begin{array}{l}7.8 \\
4.6\end{array}$ \\
\hline IIngyar... & $8,000,000$ & 59.677 & 27.848 & 7.5 & 3.5 \\
\hline Greek...... & $6,000.000$ & 44,240 & 17,162 & 7.4 & 2.9 \\
\hline i.ithuanian.. & $4,000,000$ & 25,764 & 14,538 & 6.4 & 3.6 \\
\hline kuthenian $c_{-}$. & $3,900,000$ & 23,751 & 12.059 & 6.1 & 3. 1 \\
\hline Dalmatian, Bosnian, and Herzegovinian... & $1,573,000$ & $7,2 \leq 9$ & 2,601 & 4.6 & 1.7 \\
\hline 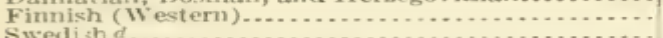 & 3.700 .000 & 14,471 & 12,436 & 3.9 & 3. 4 \\
\hline Swedish d & $5,727,000$ & 21,950 & 24.463 & 3.8 & 4. 3 \\
\hline Italian, North $\ldots . . . . . . . .1$ inontencer & 14.500 .000 & 50,510 & 30,453 & 3.5 & 2.1 \\
\hline Bulparian, Servian, and Montenegr & 9.000 .000 & 26,866 & 7.872 & 3.0 & .8 \\
\hline $\begin{array}{l}\text { Danish e } \\
\text { Boheminand inoravian. }\end{array}$ & 2.700 .000 & 7. $16 \mathrm{i3}$ & 5,831 & 2.7 & 2.2 \\
\hline $\begin{array}{l}\text { Bohemian and Moravian. } \\
\text { Portugnese.............. }\end{array}$ & $\begin{array}{l}6,000,000 \\
5,000\end{array}$ & 13,507 & 8,301 & $\begin{aligned} 2.3 \\
1.8\end{aligned}$ & 1.4 \\
\hline 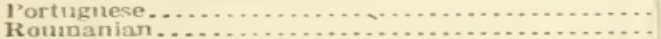 & $5,000,000$ & $9 \cdot 232$ & 5.919 & 1.8 & 1.2 \\
\hline $\begin{array}{l}\text { Roumpanian } \\
\text { English and seotch } f, \ldots \ldots \ldots\end{array}$ & 10.000 .000 & 19,016 & 6.782 & 1.9 & -7 \\
\hline 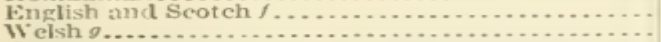 & $35,300.000$ & 61,797 & $\begin{array}{r}37,882 \\
1,619\end{array}$ & $\begin{array}{l}1.7 \\
1.5\end{array}$ & 1. 10 \\
\hline Welsh $0 . . . . . . . .$. & $\begin{array}{r}1.700 .000 \\
72,200,000\end{array}$ & $91,0.59$ & $\begin{array}{r}1,619 \\
61,253\end{array}$ & $\begin{array}{l}1.5 \\
1.3\end{array}$ & 1.8 \\
\hline Duteh and Flemish. & $9.000,000$ & 12,124 & 7,045 & 1.3 & .8 \\
\hline Armenian $h_{.} . . . .$. & $5,1000,000$ & 2,273 & 2,127 & .5 & .4 \\
\hline Spanish ................ & $20.000,000$ & 5,948 & $\begin{array}{l}2,451 \\
6,671\end{array}$ & -3 & $: 1$ \\
\hline French e including izuthenian or Little Russian of & $39,000,000$ & $\begin{array}{r}8,774 \\
16,650\end{array}$ & 6,671 & & \\
\hline 12ussia).... & $77,200,000$ & 16,652 & 6,751 & 2 & (i) \\
\hline
\end{tabular}

a The population fipures represent the total population of Norway, and the immigration figures the total number of Scanclinavians, mostly Norwegians, coming from Norway. number of Pris coming from Europe. $c$ The population figures represent the number of Ruthenians in Aisstria-1Iungary, and the immigration
figures the number of Ruthenians coming from A ustria-1Iungary. figures the population figures represent the total population of Sweden and the population of Swedes In Russia (Fiviand), and the immigration figures the total number of Scandinavians, mostly Swedes,

coming from Swedien and lzussia. total number of Scandinavians, mostly Danes, coming from Denmark.
$f$ The population figures represent the total population of Fingland and Scotland, and the immigration figures the total number of English and Scoteh coming from Elrope. El the immigration figures the total number of Welsh coming trom Europe.

$h$ Includes Armenian population in Asia and Armenians coming from Asia.

$i$ Less than 1 per 10,000 .

Figure 4: William Dillingham, Dictionary of Races or Peoples, page 7. 
ruled by force. ${ }^{216}$ From the late nineteenth to the mid-twentieth century, theories on race for both Latins and the Anglo-Saxons reflected conventional stereotypes: the Latin Southerners were sensual, ingenious but not active, while the Anglo-Saxons were regarded as able to control sexual excesses and were proper and precise. The latter two qualities were required for working in industrialized societies. ${ }^{217}$ Negative reflections on what it meant to belong to a Southern European nation grew as Italy was going through political instabilities ignited by increased socio-economic disparities between Italy's North and South. ${ }^{218}$

${ }^{216}$ Caesarism refers to the autarchic rule of one man or of an oligarchy. It takes its name from the Roman general and Consul Julius Caesar (100-44 B.C.), who dominated the Roman Republic and politics. For the Italian historian Guglielmo Ferrero (1871-1942), the Roman Empire was a major example of caesarism, and the contemporary governments of Italy, France and Spain were reproductions on a smaller scale of the same structure. French sociologist Gustave Le Bon (1841-1931) also wrote on caesarism in his work on socialism (which he opposed). Le Bon argued that "Socialism would immediately give birth to Caesarism, which would promptly suppress all the institutions of democracy." Differently from Le Bon, for Ferrero the essence of caesarism was the "systematic stealing from an agricultural populace, violently implemented by the State through taxation, in order to maintain a brilliant oligarchy of parasites." See Guglielmo Ferrero, L'Europa giovane. Studi e viaggi nei paesi del nord (Milan: Treves, 1897). See also Gustave Le Bon, The Psychology of Socialism (London: T. Fisher, 1909), 300.

217 “Così questa razza ha creato, nel mondo che parla inglese, da Melbourne a New-York, l'impero più formidabile per vitalità interiore che la storia abbia visto; ha fondato in Londra la Roma moderna; ha creato i tre più meravigliosi fenomeni sociali del mondo, il parlamento inglese, la burocrazia prussiana, il socialismo tedesco [...]." (So this race has created, in the English speaking world, from Melbourne to NewYork, the most formidable empire in history for inner vitality; has founded a modern Rome in London; has created the three most spectacular social phenomena in the world, the English parliament, the Prussian bureaucracy, the German socialism [...].) See Guglielmo Ferrero, L'Europa giovane. Studi e viaggi nei paesi del nord (Milan: Treves, 1897), 202-3.

${ }^{218}$ Giuseppe Sergi (1841-1936) was a Sicilian anthropologist who argued, and wrote extensively, on the existence of two races, the Aryan and the Mediterranean. Anthropologist Cesare Lombroso (18351909), Guglielmo Ferrero's father-in-law, also wrote on men and races. See Giuseppe Sergi, Per l'educazione del carattere. Pagine di psicologia sociale e consigli direttivi (Turin: Camilla e Bertolino, 1885); Giuseppe Sergi, Arii e Italici. Attorno all'Italia preistorica (Turin: Bocca, 1898); Giuseppe Sergi, La Decadenza Delle Nazioni Latine (Turin: Bocca, 1900); Cesare Lombroso, "Sull'antitalianismo degli Italiani," Nuova Antologia 90 (1901): 319-23. 
Italy's South suffered a major economic crisis as result of the new isolationist economic measures implemented in the 1870 s by the Italian government. With the 1876 election, socialist-leaning officials replaced the liberal party that had governed since 1861. The first leftist government, led by Prime Minister Agostino Depretis (1813-87), opposed the liberal economic doctrine that supported free trade and the government's nonparticipation in economic transactions. ${ }^{219}$ Depretis advocated the state's supremacy in the economy. His government financed major public works and favored the birth of the first Italian industries in the Northern regions of the peninsula. Chemical, textile, and steel factories employed masses of workers, mainly from the Northern region where the facilities were situated. In order to protect these industries from foreign competition, Depretis adopted protectionism. Tariffs on foreign imports caused retaliation by foreign countries and damaged Southern farmers who could not sell their products on foreign markets. Depretis, and later Francesco Crispi (1818-1901), also from the Left, complemented their myopic economic strategies with a new political practice named 'transformism' (trasformismo) ${ }^{220}$ Through transformism, Italian political leaders aspired to govern from a non-partisan perspective. For Gramsci, transformism represented a victory of the Italian dominant class, because it had been able to identify Southern Italian

\footnotetext{
219 Philosopher Adam Smith (1723-90) advocated Liberalism, an economic philosophy supporting laissez-faire and private property in the means of production. Liberalism also opposed government's intervention in the market, and mercantilism, which instead encouraged governments' control of foreign trade. See Adam Smith, An Inquiry Into the Nature and Cause of the Wealth of Nations (London: W. Strahan and T. Cadell, 1776).

${ }^{220}$ Transformism (trasformismo) was a practice initiated by Depretis aiming to resolve differences disregarding or bypassing parties' programs and ideologies. In its pejorative meaning, transformism suggested lack of programmatic and ideological coherence.
} 
intellectuals (as Crispi) or Northern intellectuals of humble origins (as Depretis) thus separating them from the mass of peasants and integrating them into the mainstream of national and international "high" culture. Consequently, the intellectuals from both North and South were detached from the people. ${ }^{221}$ The practice, however, was mainly a corrupt system to gain and maintain power. Intellectuals and politicians agreed on the differences between the South and the rest of the country. They contended that the Italian South was a naturally poor region inhabited by a racially different population, but did little to solve the problem. ${ }^{222}$ The "Southern question" got worse, and the racial boundaries strengthened.

The Italian lower classes were well aware of political and race issues. As folksongs and folktales show, the influences that reached the Italian peninsula from different areas in the Mediterranean also contributed to shape regional differences within Italy. The first folksong I will address is Era bella come gli orienti (Beautiful it was, as the Orient), of anonymous authorship, from North Italy. ${ }^{223}$ This song is important because it exemplifies how the people of the lower classes internalized their subordinated status.

${ }^{221}$ Leonardo Salamini, “Towards a Sociology of Intellectuals: A Structural Analysis of Gramsci’s Marxist Theory," in Antonio Gramsci: Critical Assessments of Leading Political Philosophers, James Martin (New York: Taylor \& Francis, 2002), 73.

${ }^{222}$ Giovanni. Sabbatucci, Il Trasformismo Come Sistema. Saggio Sulla Storia Politica Dell'Italia Unita (Rome-Bari: Laterza, 2003); Claudio Cesa, Tardo Positivismo, Antipositivismo, Nazionalismo (Florence: Olschki, 1981); Silvana Patriarca, Italian Vices: Nation and Character from the Risorgimento to the Republic (Cambridge: Cambridge University Press, 2010), 8.

${ }^{223}$ Quoted in Franco Castelli, “Per Un’antropologia del Risorgimento,” editorial (2011), p. 9. 
E la Cicilia l'è un'isoletta, ${ }^{224}$

l'è un isoletta in mezzo al mar, la-rallalà, e la Cicilia l'è un'isoletta

noi la faremo sprofondar.

E il re di Napoli

coi suoi cannoni

noi lo faremo sprifondar.

E detto fatto

si suona il campanello,

e salta fuori

Vittorio Emmanuello.

E Garibaldi faceva 1'oste,

Napoleone il cameriere, trullalà, e la regina dell'Inghilprussia

la ghe lavava giò i biccér.
And Sicily is a small island, is an island in the middle of the sea, larallalà,

Sicily is an island and

we'll make it collapse.

And the King of Naples

with his cannons

we'll make him collapse.

But wait, ring the bell, and Victor Emmanuel will come. ${ }^{225}$

And Garibaldi was the tavern's landlord, Napoleon the waiter, trullalà, while the Queen of Inghilprussia was busy washing the glasses.

This song began to circulate in Northern Italy after Napoleon's fall from power in 1815 and survived until World War I. It was a medley modified in different periods. Folklorist Paolo Toschi argued that changes in the lyrics over the years derived not only from memory errors or other elements peculiar to oral transmissions, but often from the necessity of adapting a text imported from a different time or place to the current circumstances. ${ }^{226}$ This particular stanza of Era bella come gli orienti can be read as a

\footnotetext{
${ }^{224}$ Cicilia is ancient Florentine dialect for "Sicilia", Sicily. See Giovanni Boccaccio, "Decameron". A hint to the North-South diatribe can be perceived in this verse.

${ }^{225}$ Popular common sense resolves the Southern question by calling Victor Emmanuel II, who appears at the ringing of a bell as a servant. It is obviously the first phase of Italy's unification, when people belonging to the lower classes still believed that the Savoy monarchy's function was to free them from foreign domination.
}

${ }^{226}$ Paolo Toschi "Nel propagarsi, un canto non rimane mai uguale. Ogni individuo che lo ricanta, se ne impossessa, lo fa suo non solo adoperandolo per il proprio caso, ma dandogli la sua impronta individuale e quindi modificandolo". Paolo Toschi, Fenomenologia del Canto Popolare (Roma: Edizioni dell'Ateneo, 1951), 59. 
timeline of Italian history from the common folks' point of view, from the 1815 Congress of Vienna to the post- unification period (1861 and the following years). In 1815, the statesmen of Austria, France, Great Britain, Russia, and Prussia regarded the Italian peninsula as little more than a mere "geographical expression" on the European map, a land to divide between themselves. ${ }^{227}$ The song expressed people's awareness of their subordinate status in the eyes of the foreign powers that had controlled much of Italy until the end of the nineteenth century. Popular contempt for foreign rulers, lack of confidence in the undertakings of Risorgimento's leaders, and disdain towards the King of Italy emerge in both the staging elements in the lyrics (the tavern; the kitchen; the invented land of Anglo-Prussia) and in the roles attributed to the characters in the song. Interpreting the historical context of the actions that these persons perform in the song's lyrics unveils the popular mindset: the sovereign of Anglo-Prussia (InghilPrussia) was debased to a kitchen maid engaged in domestic chores in a tavern, whereas Napoleon was a servant and Garibaldi the innkeeper. Garibaldi's higher status over foreign invaders in the hierarchical labor scale is important. Like a savior ready to intervene in case of need (or like a servant ready to take orders), King Victor Emmanuel arrived at the ringing of a bell. The song was popular among the workers of the numerous mills in and around

${ }^{227}$ In a letter to the Austrian ambassador to France, Prince Clemens von Metternich (1773-1859) wrote on April 1847 "The word 'Italy' is a geographical expression, a description which is useful shorthand, but has none of the political significance the efforts of the revolutionary ideologues try to put on it, and which is full of dangers for the very existence of the states which make up the peninsula." Historian Fausto Brunetti argues that Metternich's quote is the product of disinformation committed by the daily Neapolitan newspaper Il Nazionale. An Italian case of "yellow journalism" where Il Nazionale manipulated Metternich's quote to foment 1848 rebellions against the Austrians in North Italy. See Fausto Brunetti, L'Italia è una esperienza geografica. Manipolazione e trasfigurazione di una celebre frase metternichiana (Roma: Edizioni Libreria Croce, 2005). 
Milan (filerine) ${ }^{228}$ Scholars of musical folklore wrote that when the original source of a text was forgotten, it became an expression of popular sentiment. ${ }^{229}$ In this case, the verse "Sicily is an island and we'll make it collapse" voiced the Northern popular notion of North-South relations. When intellectuals and politicians spoke for the interest of the lower classes de facto, they actually worked to harm the lower classes (as we saw in discussing Depretis, Crispi and transformism); when intellectuals, who claimed to speak in the name of reason and truth advanced racial arguments, in effect they only proposed an apology for Southern inferiority (see Sergi, Ferrero, and Lombroso); when both categories of leaders preached but offered no plans for change, then the contention that a racially different population lived in the poorest regions of Italy seemed to confirm the "survival of the fittest" hypothesis.

The work on races that Italian anthropologists produced in the two last decades of the nineteenth century contributed to "orientalize" the South. Anthropologist Giuseppe Sergi added to the Hegelian debate on universal history and Eurocentrism through his claim that the Mediterranean Sea not only was the axis of universal history, but also the birthplace of the great Mediterranean race. ${ }^{230}$ By doing so, he actually corroborated the idea of the existence of two races within Europe. For Sergi, the Mediterraneans derived

\footnotetext{
${ }^{228}$ Serafino Baj, Canti di guerra e patriottici. Raccolti e pubblicati a cura di Baj Serafino dedicati alla memoria del compianto presidente federale dei combattenti di Milano Cap. Giuseppe Cancelliere animatore dei canti di guerra (Milano: La tipografica, 1933), 60-2.

229 Giuseppe Cocchiara, L'Anima del Popolo Italiano Nei Suoi Canti (Milano, 1929), 68; Alberto Ciresi, La Poesia Popolare: Storia Della Critica (Palermo: Palumbo Editore, 1925), 71.

${ }^{230}$ Giuseppe Sergi, Origine e Diffusione Della Stirpe Mediterranea (Rome: D. Alighieri, 1895).
} 
neither from the black nor white peoples and probably spoke a Hamitic language related to the language of the prehistoric Egyptians, Iberians, and Libyans. ${ }^{231} \mathrm{He}$ believed that the Roman imperial expansion spread "the finest brunette race which has appeared in Europe", from which the Nordic race derived. ${ }^{232}$ Sergi opposed theories of Nordic supremacy, but his contention that North Europeans, including Northern Italians, had become more disciplined, productive civic-minded than Southerners because rigid climate forced them to develop close-knit groups in order to survive an adverse environment, ended up being used by his opponents. ${ }^{233}$ All of these views coalesced in the popular belief of race predestination, either to survival or to collapse, as illustrated in the verses of the song.

Folksongs and folktales also referred to contacts between peoples from different regions of the Mediterranean. Societal cultural exchanges across the Mediterranean Sea confirm historian David Abulafia's argument that the Mediterranean played an essential

${ }^{231}$ Giuseppe Sergi, Origine e Diffusione Della Stirpe Mediterranea (Rome: D. Alighieri, 1895).

${ }^{232}$ Sergi called the Nordic race "Aryanized Africans" and identified this race as the interbreeding of Euroasian (Aryans) and Mediterraneans. See Giuseppe Sergi, Origine e Diffusione Della Stirpe Mediterranea (Rome: D. Alighieri, 1895).

${ }^{233}$ Giuseppe Sergi (1841-1936) was a Sicilian anthropologist who argued, and wrote extensively, on the existence of two races, the Aryan and the Mediterranean. Anthropologist Cesare Lombroso (18351909), Guglielmo Ferrero's father-in-law, also wrote on men and races. See Giuseppe Sergi, Per l'educazione del carattere. Pagine di psicologia sociale e consigli direttivi (Turin: Camilla e Bertolino, 1885); Giuseppe Sergi, Arii e Italici. Attorno all'Italia preistorica (Turin: Bocca, 1898); Giuseppe Sergi, La Decadenza Delle Nazioni Latine (Turin: Bocca, 1900); Cesare Lombroso, "Sull'antitalianismo degli Italiani," Nuova Antologia 90 (1901): 319-23. 
role into bringing very diverse cultures into mutual contact. ${ }^{234}$ While this is not an original argument, it is important for this study because Abulafia uses it as a springboard to move contemporary debate on the concept of the Mediterranean onto another plane. Not exclusively the essential medium for maritime trade exchange among the 'classic' Mediterranean lands, for Abulafia Mediterranean becomes a term to signify the empty space between lands on opposing shores where culture, and goods, circulate. In a way, it is a return to the etymological meaning of the word: medius (middle) and terra (land). Abulafia calls these empty spaces of encounters "Mediterraneans" and believes that they "are not necessarily seas in the sense that we normally understand the term." 235 This macro reading of the Mediterranean aids in any assessment of the exchange of cultures and the formation (or transformation) of identities that took place between Italy (on the Southern shores of Europe) and Southeast Florida (on the Southeastern shores of the United States) that will be discussed in the following chapters. A 1938 study of Italian folksongs by musicologist Ermanno Gizzarelli fits into Abulafia’s narrative. Gizzarelli tracked Greco-Arabic elements in songs from Sicily, Calabria, and Sardinia and showed that melodies from Southern Italy and Sardinia also presented aspects of Arab, Greek, and Spanish music. ${ }^{236}$ He found French influences in plays from Piedmont and Tuscany,

\footnotetext{
${ }^{234}$ David Abulafia, "Mediterraneans," in Rethinking the Mediterranean, in Rethinking the Mediterranean, William V. Harris (Oxford: Oxford University Press, 2005), 64-93.

${ }^{235}$ I prefer "mediterranean", in order to deflect focus from the geographical proper name "Mediterranean". See David Abulafia, "Mediterraneans," in Rethinking the Mediterranean, in Rethinking the Mediterranean, William V. Harris (Oxford: Oxford University Press, 2005), 65.

${ }^{236}$ Ermanno Francis Gizzarelli, "An Historical Survey of Italian Folk Song and a Critical Estimate of Modern Research" (Ph.D. diss., New York: Cornell University, 1938).
} 
along with traces from the French troubadours' repertoires. Veneto and Istria's folksongs showed German inspirations. ${ }^{237}$ Similarly, music from Sardinia and the Abruzzi echoed ancient music of a prehistoric or early historical time found in a few areas of Spain and France or in secluded areas of Russia or Africa, while the provinces of Veneto, Trento, Friuli, and Istria maintained characteristics autonomous only to these regions. Musical instruments characterized the North-South divide of the Italian peninsula. The accordion was a common instrument, but in Sicily and Sardinia musicians preferred the shepherd's pipe, the bagpipe, the tambourine, the friction drum and only in Sardinia the launeddas, a type of wind/string/percussion instrument, which produced a music that echoed ancient sounds. ${ }^{238}$ The South's maritime trade within the Mediterranean world (with Phoenicians, Greeks, and Arabs) explained the strident, falsetto voices of some of the singers in the South. Folktales also referred to contacts between peoples from different regions of the Mediterranean. Italian folklorist and writer Italo Calvino wrote that folktales are real. ${ }^{239}$ Contacts between Southern Italians and the Moors were so tangible that "Moors" entered the iconography of Southern folktales, as in The Moor's Bones tale. ${ }^{240}$ By contrast in

\footnotetext{
${ }^{237}$ Ermanno Francis Gizzarelli, "An Historical Survey of Italian Folk Song and a Critical Estimate of Modern Research” (Ph.D. diss., New York: Cornell University, 1938), 72-3.

${ }^{238}$ Launeddas seemed to be of Phoenician origins. See Ermanno Francis Gizzarelli, “An Historical Survey of Italian Folk Song and a Critical Estimate of Modern Research" (Ph.D. diss., New York: Cornell University, 1938).

${ }^{239}$ Italo Calvino, Italian Folktales, George Martin (San Diego: Harcourt Brace Jovanovich, Publishers, 1980 [1st ed. 1956]), xviii.

${ }^{240}$ It is the story of a widower king with a son, who married a woman and soon died. The son remained with the stepmother, who fell in love with a Moor, paying no attention to the son. The child grew up, killed the Moor and showed the queen's malice and treachery to the judges and the people of his
} 
the North, trade and circulation of people and goods took place mainly with Germanic and Celtic peoples, and folktales presented these encounters. Shoemakers and gnomes, for example, are recurrent characters in Trentino Alto Adige's folktales as well as in Grimms' Brothers collection. ${ }^{241}$ Such folktales provided evidence that regional identities in Italy contained elements from many mediterraneans - in Abulafia's term - that were not distinctively Italian.

Folktales and folk music mirrored the Mediterraneanism-Nordicism polarity circulating in the years that bridged the nineteenth and the twentieth centuries. ${ }^{242}$ As already discussed, contemporary anthropologists' portrayal of people of the Mediterranean race was interpreted and used by Nordicists in negative terms. For example, supporters of the superiority of the Nordic/Aryan race used Sergi's discussion of public subsidy as a practice dating back to the last period of the Roman Empire to

kingdom. The woman was condemned to death. This tale was told in the Southern town of Benevento, in Campania. See Italo Calvino, Italian Folktales, [trans.] George Martin (San Diego: Harcourt Brace Jovanovich, Publishers, 1980 [1st ed. 1956]), 420.

${ }^{241}$ Gli gnomi e il calzolaio is a very popular folktale in Val Badia, Trentino Alto Adige, a region in Northeast Italy. Its incipit "Il sole stava ormai scivolando dietro le slanciate guglie della Val Badia" (The sun was slipping behind the slender spires of Val Badia) makes it Italian, but the plot and the characters are the same as in the Grimm Brothers' version of The Elves and the Shoemaker by the Grimm Brothers. See Jacob and Wilhelm Grimm, More Tales from Grimm, Wanda Gâag (Minneapolis: University of Minnesota Press, 2006), 251.

${ }^{242}$ Among the supporters of the superiority of the Nordic race: Carlo Formichi (1871-1943); Arthur Schopenhauer (1788-1860), Arthur de Gobineau (1816-1882), Theodor Poesche (1824-1899); Karl Penka (1847-1912); Thomas Henry Huxley (1825-1895). See Arthur Schopenhauer, Parerga e Paralipomena (Milan: Adelphi, 1981 [1st orig. edition 1851]); Joseph-Arthur Gobineau, Essai sur l'inégalité des races humaines (Paris: Éditions Pierre Belfond, 1967 [1st original ed. 1853-1855]); Karl Penka, Origins of the Aryan (1883); Theodor Poesche, The Aryans: A Contribution to Historical Anthropology (1878); Thomas Henry Huxley, "On the Geographical Distribution of the Chief Modifications of Mankind," Journal of the Ethnological Society of London III (1870). 
demonstrate that both the Southern inhabitants of Italy, and more broadly the Latin peoples of Europe, exhibited traits of servility and passivity as a consequence of such corrupting practices. ${ }^{243}$ For them, the recurrence of public subsidies had become such a frequent practice in contemporary Italy, that it was doomed to condemn South Italy to decadence. ${ }^{244}$ Italian Southerners were not proud to be Italian either. In South Italy, people questioned their Italianità and lamented their condition, as the following Sicilian song illustrates

...E sono italiano

Non so come non mi rivolta la testa pensando al presente ed al passato. Vedo tante persone che fan festa, ne vedo tante altre di cattivo umore, vedo il mare ch'è sempre in tempesta, vedo persone che mutano stato, vedo me stesso, e pare caso strano: nacqui in Sicilia, e sono italiano.

Dunque a questo mondo nulla c'è da fare: siamo in mezzo a tanti traditori, non si sa più da chi ci si può guardare, non ci sono amici, né fede né onore.

\section{... And I am Italian}

I do not know why my head does not spin thinking about the present and the past. I see many people who celebrate I see many others in a bad mood, I see the sea which is always in the storm, I see people changing condition, I look at myself, and it seems strange: I was born in Sicily, and I am Italian. So in this world there is nothing to do: we are in the midst of so many traitors, no one knows by whom we must guard there are no friends, no faith nor honor.

${ }^{243}$ Sergi's position echoed Gottfried von Herder and Herder's student Heinrich Leo, who assigned an important role to geography and climate. See Giuseppe Sergi, Per l'educazione del carattere. Pagine di psicologia sociale e consigli direttivi (Turin: Camilla e Bertolino, 1885); Giuseppe Sergi, Arii e italici. Attorno All'Italia preistorica (Turin: Bocca, 1898); Giuseppe Sergi, La decadenza delle nazioni latine (Turin: Bocca, 1900), 252. See also: Aaron Gillette, Racial Theories in Fascist Italy (London and New York: Routledge, 2002). As Prime Minister (five times in Italy's history in the period 1892-1921) Giovanni Giolitti (1842-1928) offered subsidies for low-income housing, preferential government contracts for worker cooperatives, and old age and disability pensions.

${ }^{244}$ Sergi affirmed that indeed Italians had an inclination to demand everything from the state, which he described as a residuum of the Roman concept of state. Sergi believed that Greece first, and then ancient Rome were examples of greatness, but in its declining phase the Roman Empire had corrupted the masses through public subsidies and thus rendered them servile and anarchic. It was then that Latin individualism had begun to degenerate. Giuseppe Sergi, La decadenza delle nazioni latine (Turin: Bocca, 1900); Aaron Gillette, Racial theories in Fascist Italy (London and New York: Routledge, 2002). 
Ciascuno pensa al modo di rubare:

è scomparso dalla faccia ogni pudore?

È vero che ora c'è la fratellanza?

Ma Cristo Santo!... la miseria avanza!
Everyone thinks of a way to steal: has all sense of shame disappeared? Is it true that there is now brotherhood? But for Christ's sake! ... despair advances! $!^{245}$

The song's lyrics describe the state of uncertainty with which the Sicilian masses faced unification. A strong belief that unification did not produce substantial changes in living conditions and a lack of confidence in the way leaders conducted the new state's affairs led the song's protagonist to accept his condition of "Italian" only reluctantly.

Popular songs and folktales from every region exposed the destitute state of the peasantry. Folktales are a useful source to historians, because they become part of the cultural fabric and are internalized by people. In turn, these ideas became common places that inform policies and, eventually, reveal racist, classist, and sexist stereotypes. In folktales, the peasants were depicted as always in search of a means to survive. In this sense the discourse insinuates that only a miracle could rescue them from starvation and destitution. The presence of magic elements, allegories of external interventions, represented popular resignation and the idea that indigence was a natural state that only extraordinary events could modify. Interestingly, fishermen, peasants, and farmers were depicted as heroes in the majority of folktales. ${ }^{246}$ Society in folktale was hierarchical, but

\footnotetext{
${ }^{245}$ Antonino Uccello, Risorimento e Società Nei Canti Popolari Siciliani (Catania: Pellicano Libri, 1978), 325-6.

${ }^{246}$ For example, see the following folktales: Joseph Ciufolo, Tiller-Flutist (Tuscany); Out in the world (Abruzzo); Fourteen (Marche); Misfortune (Sicily) in Italo Calvino, Italian Folktales, [trans.] George Martin (San Diego: Harcourt Brace Jovanovich, Publishers, 1980 [1st ed. 1956]), 393; 616; 356; 529.
} 
different from the real one: it allowed hard working, ambitious, or virtuous common folk

to acquire higher status. In the same way, high rank could be debased by wrong doing.

Folktales where an ordinary person was transformed into someone extraordinary carried a social function. They promised redemption.

\section{Within the Child Lies the Fate of the Future, 1900-1915 247}

The debate on race continued in the twentieth century, but intellectuals shifted the focus to education. ${ }^{248}$ Historian and politician Napoleone Colajanni (1847-1921) believed that the cause of the Southern problem was primarily social and environmental. ${ }^{249}$ If

${ }^{247}$ Maria Montessori, The Secret of Childhood (Orient Longman, 1978).

${ }^{248}$ Burkhardt influenced Turiello. By recurring to positivistic culture and using Spencer, Darwin, and Lombroso's theories, he set out to examine the character of all Southern Italian people to understand the real conditions of the country. His conclusions were that Neapolitans were the people that most exhibited all the traits of the Italianità. Not having experienced the 'communes' institutions, they had preserved in greater fashion the original or 'native' Italian character that elsewhere had been modified by the political and civic experience of the communes. Turiello called the main Neapolitan/Italianità's characteristic scioltezza; (looseness). However, for Turiello the concept of dolce far niente was a foreigners' invention. From the mid1880s nationalist, exponents from the extreme Left and intransigent Catholics joined their voices to criticize the weakness and corruption of the Italian parliament. The psychiatrist Scipio Sighele described the chamber of deputies as "psychologically a female and often even a hysterical female". The philosopher of history Nicola Marselli and the historian Enrico Zanoni joined Turiello's voice in denouncing that in their days Italians still lacked the qualities of the powerful Northern peoples, namely discipline, a sense of duty, and character. All of these gloomy disquisitions Pessimistic as they may appear, these positions Sergi accused Italians of two other severe offenses: 1) "classicism", i.e. the excessive reliance on classical culture and the envisioning of the future only through the lenses of the past, and 2) Catholicsm. These features, of course, were not innate, but the results of historical circumstances. This was enough for Sergi to argue that the decadence of Latin nations was not inevitable and adequate measures could invert the process. See Turiello, Governo e Governati in Italia, 108; Cesa, Tardo Positivismo, 18; Scipio Sighele, Contro Il Parlamentarismo. Saggio di Psicologia Collettiva (Milan: Treves, 1895), 34.; Enrico Zanoni, Studio Sui Caratteri Nazionali (Milan: Robecchi, 1883); Nicola Marselli, Gl’Italiani del Mezzogiorno (Rome: Sommaruga, 1884).

${ }^{249}$ Among them the criminologist Cesare Lombroso (1835-1909) and the statistician Alfredo Niceforo (1876-1960). See also Francesco Pullé, "Profilo antropologico dell'Italia," Archivio per l'antropologia e la etnologia (1898): 19-163 Archivio per l'antropologia e la etnologia, Paolo Mantegazza; Alfredo Niceforo, Italiani del nord e italiani del sud (Turin: Bocca, 1901); Cesare Lombroso, "Sull'antitalianismo degli Italiani," Nuova Antologia 90 (1901): 319-23; Napoleone Colajanni, Latini e Anglo-Sassoni (razze inferiori e razze superiori) (Rome-Naples: Presso la Rivista Popolare, 1906); 
social contingencies and environment affected people, as Colajanni argued, then education was the way to bring about change. Surveys and research seemed to confirm this argument.

In 1906, journalist and pedagoge Paola Lombroso (1871-1954) and criminologist Mario Carrara (1866-1937) circulated a questionnaire among farmers and peasants in Northern Italy to gain an insight into popular opinion on concepts of homeland, monarchy, and Risorgimento. Paola Lombroso was Cesare Lombroso's daughter and Mario Carrara was one of Cesare Lombroso's students. They both followed his philosophy. Their survey was a project that fulfilled the interests of both Paola Lombroso and Carrara, who were commited to helping members of the lower classes by stimulating policy reform. Of the forty-three people interviewed, sixteen were farmers from Voltaggio and Basaluzzo, two villages in Piedmont, (four men and twelve women aged between twenty and thirty-five.) The survey posed general knowledge questions: "What is a congressman?" "What is the [Italian] Statute?", "Who is the king?", "What is war?", "Why do you pay taxes?”, and asked the meaning of words such as hygiene, indigenous, missionary, colony, court of justice, antiques, and economics. The answers revealed that the king seemed to have lost his sacred status and inviolability as described in the first Italian Constitution, the Statute. ${ }^{250}$ For a 31 year old peasant woman, who had been

${ }^{250}$ In 1848, Charles Albert of Savoy (1798-1849), King Victor Emmanuel's father, conceded a Constitution to his Kingdom of Piedmont-Sardinia. This Constitution, known as Albertine Statute, became the Kingdom of Italy's first Constitution in 1861. The person of the king was sacred and inviolable (sacra e inviolable), as shown in article 4. "Art. 4. - La persona del Re è sacra ed inviolabile." 
intermittently in school for six years, the king was "a man like any other." ${ }^{251} \mathrm{He}$ was "neither the most beautiful, nor one of the worst; during war time, he was full of troubles, but in time of peace he stayed home to regulate the affairs of others: the king was rich but had many hassles." 252 For another peasant woman: "In time of war the king is more fearful than others, and he hides under a tree, behind a fence or in a house; and the soldiers say 'it is easy to order us to kill while he just stands hidden there!" ${ }^{253}$ Lombroso and Carrara noted that the majority of the interviewees ignored the meaning of "Statute": for an illiterate 45 year old woman, it indicated election day; for another literate 26 year old woman it was a name given to the Virgin Mary; a 39 year old farmer declared that it was a contract used in business transactions. The authors of the survey were surprised to discover that only three people knew the meaning of the word hygiene. Lombroso and Carrara claimed that their greatest shock was the answer to the question "What names do you know of great men?” The peasants replied with the names of the bandits Giuseppe Musolino (1876-1956) from South Italy, and Giuseppe Mayno (1780-1806, also known as Mayno Spinetta) from Piedmont, along with those of King Victor Emmanuel, and the

\footnotetext{
${ }^{251}$ Paola Lombroso and Mario Carrara, Nella penombra della civiltà. Inchiesta sul pensiero del popolo (Torino: Fratelli Bocca, 1906). Quoted in Franco Castelli, "Per Un'antropologia del Risorgimento," editorial (2011).

${ }^{252}$ Paola Lombroso and Mario Carrara, Nella penombra della civiltà. Inchiesta sul pensiero del popolo (Torino: Fratelli Bocca, 1906). Quoted in Franco Castelli, "Per Un'antropologia del Risorgimento," editorial (2011), p. 93.

${ }^{253}$ Paola Lombroso and Mario Carrara, Nella penombra della civiltà. Inchiesta sul pensiero del popolo (Torino: Fratelli Bocca, 1906). Quoted in Franco Castelli, "Per Un'antropologia del Risorgimento," editorial (2011), 93-4.
} 
revolutionaries Giuseppe Mazzini and Giuseppe Garibaldi. ${ }^{254}$ Apparently, in 1906 the name Giuseppe was the only common patrimony, shared between Northern and Southern Italians. Giuseppe was a name that merged military and social ranks, literati and members of the lower classes. For the lower classes, the Italian founding fathers shared popular respect and esteem side by side with brigands. Curiously, Mayno's memory, and not that of the king or of Mazzini or Garibaldi, remains vivid in popular culture, as his legend has been interpreted and performed in 2009 by students in a school in Piedmont. The two surveyors' surprise is also revealing for modern readers. ${ }^{255}$

Carrara and Lombroso's amazement exposed the bias of the scientists who approached the subjects of their study with prejudice. Their reactions and those of their colleagues, however, brought beneficial changes to the lower classes of Italians because they promoted education. To intellectuals of this period, raising the literacy level became of prime importance. This idea went hand-in-hand with that of discipline, a quality that

\footnotetext{
${ }^{254}$ Paola Lombroso and Mario Carrara, Nella penombra della civiltà. Inchiesta sul pensiero del popolo (Torino: Fratelli Bocca, 1906). Quoted in Franco Castelli, "Per Un'antropologia del Risorgimento," editorial (2011), p. 94. Giuseppe Musolino was born in Santo Stefano d'Aspromonte, in the Southern region Calabria. A recent revisionist scholarship argues that Musolino became an outlaw after false accusation of murder in 1897. He became a popular hero (a sort of Robin Hood) and legends flourished around him. He became the subject of Calabrian folktales and songs. Also Giuseppe Mayno was a popular hero in the Piedmont region, where he was born, and in other Northern districts. He opposed the French occupation of Piedmont and for three years, from 1803 to 1806, resisted Napoleonic troops. He was the terreur des Departements au delà des Alpes (terror of the departments beyond the Alps). He called himself king of Marengo (the area in Piedmont where he lived) and emperor of the Alps, in obvious mockery of established order. Popular fascination with characters as Musolino and Mayno still persist.

${ }^{255}$ Paola Lombroso and Mario Carrara, Nella penombra della civiltà. Inchiesta sul pensiero del popolo (Torino: Fratelli Bocca, 1906). Quoted in Franco Castelli, "Per Un'antropologia del Risorgimento," editorial (2011), p. 94.
} 
Italians lacked, according to many of these scholars. ${ }^{256}$ Between 1861 and 1929, the Italian government passed eight laws to regulate education and to improve literacy, with an average of a new law every two years from 1904 to $1911 .^{257}$ In 1871 , the illiteracy rate stood at 50 percent in Piedmont, 53 percent in Lombardy, 75 percent in Emilia Romagna, 89 percent in Calabria, 87 percent in Sicily, and 88 percent in Sardinia. The disparity in literacy rates in the various regions are a further indication of the divide between North and South Italy. Overall, the 'national' rate of illiteracy dropped significantly from 74 percent in1861 to 27.3 percent in $1921 .^{258}$

A group of journalists acknowledged that the state of public education was among the major problems delaying the country's development and wrote vehement articles to request state intervention. ${ }^{259}$ The 1908 opening manifesto of the Florentine journal $\mathrm{La}$ Voce denounced the state of public education and the problem of regional divisions, and

\footnotetext{
${ }^{256}$ Even the poet Giosue ' Carducci lamented the lack of virility of the new Italy and lashed out at the "people of cicisbei" and at the slothful individuals that Italians had never ceased being. Giosue Carducci, "Ça Ira," in Prose di Giosue Carducci (Bologna: Zanichelli, 1898).

${ }^{257}$ Legge Casati, 1861; Legge Coppino, 1877; Legge Orlando, 1904; Legge n. 383, 1906; Legge Credaro, 1911; Legge Gentile, 1923; Concordato, 1929, in Fabrizio Dal Passo, "Il Sistema Scolastico Dalla Fase Preunitaria All'Italia Unita (1848-1948)," manuscript in Storia della scuola italiana (2013), 1-77.

${ }^{258}$ Legge Casati, 1861; Legge Coppino, 1877; Legge Orlando, 1904; Legge n. 383, 1906; Legge Credaro, 1911; Legge Gentile, 1923; Concordato, 1929, in Fabrizio Dal Passo, "Il Sistema Scolastico Dalla Fase Preunitaria All'Italia Unita (1848-1948)," manuscript in Storia Della Scuola Italiana (2013), 75. For illiteracy rates, see Carlo Cipolla, Istruzione e sviluppo (Bologna: Il Mulino, 2002), 79.

${ }^{259}$ Giuseppe Prezzolini (1882-1982), Giovanni Papini (1881-1956), Gaetano Salvemini (18731957), Giuseppe De Robertis (1888-1963).
} 
demanded the renewal of Italian culture and a "national resurgence of the Italian

character." 260

We do not promise to be genius, to unravel the mystery of the world and of determining the exact menu and daily actions that are needed to become great men. But we promise to be HONEST and SINCERE. We strongly feel the ethics of intellectual life, and to see the misery and the revolting traffic reserved to the things of the spirit makes us vomit. These are the infinite negative forces that we intend TO DENOUNCE and TO FIGHT. They all know them, many speak about them, and no one condemns them publicly. [The negative forces to fight] are verdicts emitted light-heartedly and without the possibility of discussion, the charlatanism of artists and thinkers who are deficient and without kidneys, the profit and the work of the manufacturers of literature, the empty bureaucracy that automatically solves every problem. We want TO WORK. Already we aim to keep up with certain social movements that are complicated by ideologies such as modernism and trade unionism; [we want to] INFORM, without much desire for novelty, of what they do best abroad; [we want to] PROPOSE reforms and improvements to public libraries, to take care of the moral crisis of the Italian universities; [we want to] REPORT the works worthy of reading and COMMENT on the cowardice of contemporary life. ${ }^{261}$

This language was strong, each word was meant to stir sensitive issues and to disturb a

status quo that was detrimental to Italy's advancement. Again Italianità became a

recurrent theme in the political discourses of the first decade of the twentieth century.

${ }^{260}$ Giuseppe Prezzolini, “La Nostra Promessa,” La Voce, 1908, 27 December 1908.

261 “ Non promettiamo di essere dei geni, di sviscerare il mistero del mondo e di determinare il preciso e quotidiano menudelle azioni che occorrono per diventare grandi uomini. Ma promettiamo di essere ONESTI e SINCERI. Noi sentiamo fortemente l'eticità della vita intellettuale, e ci muove il vomito a vedere la miseria e l'angustia e il rivoltante traffico che si fa delle cose dello spirito. Sono queste le infinite forme d'arbitrio che intendiamo DENUNCIARE e COMBATTERE. Tutti le conoscono, molti ne parlano; nessuno le addita pubblicamente. Sono i giudizi leggeri e avventati senza possibilità di discussione, la ciarlataneria di artisti deficienti e di pensatori senza reni, il lucro e il mestiere dei fabbricanti di letteratura, la vuota formulistica che risolve automaticamente ogni problema. Di LAVORARE abbiamo voglia. Già ci proponiamo di tener dietro a certi movimenti sociali che si complicano di ideologie, come il modernismo e il sindacalismo; di INFORMARE, senza troppa smania di novità, di quel che meglio si fa all'estero; di PROPORRE riforme e miglioramenti alle biblioteche pubbliche, di OCCUPARCI della crisi morale delle università italiane; di SEGNALARE le opere degne di lettura e di COMMENTARE le viltà della vita contemporanea..." In Giuseppe Prezzolini, "La Nostra Promessa," La Voce, 1908, 27 December 1908, p. 1. 
The journalist Giuseppe Prezzolini (1882-1982), who often wrote in La Voce, depicted a depressing picture of intellectual life in Italy. ${ }^{262}$ He wished to utilize the journal to
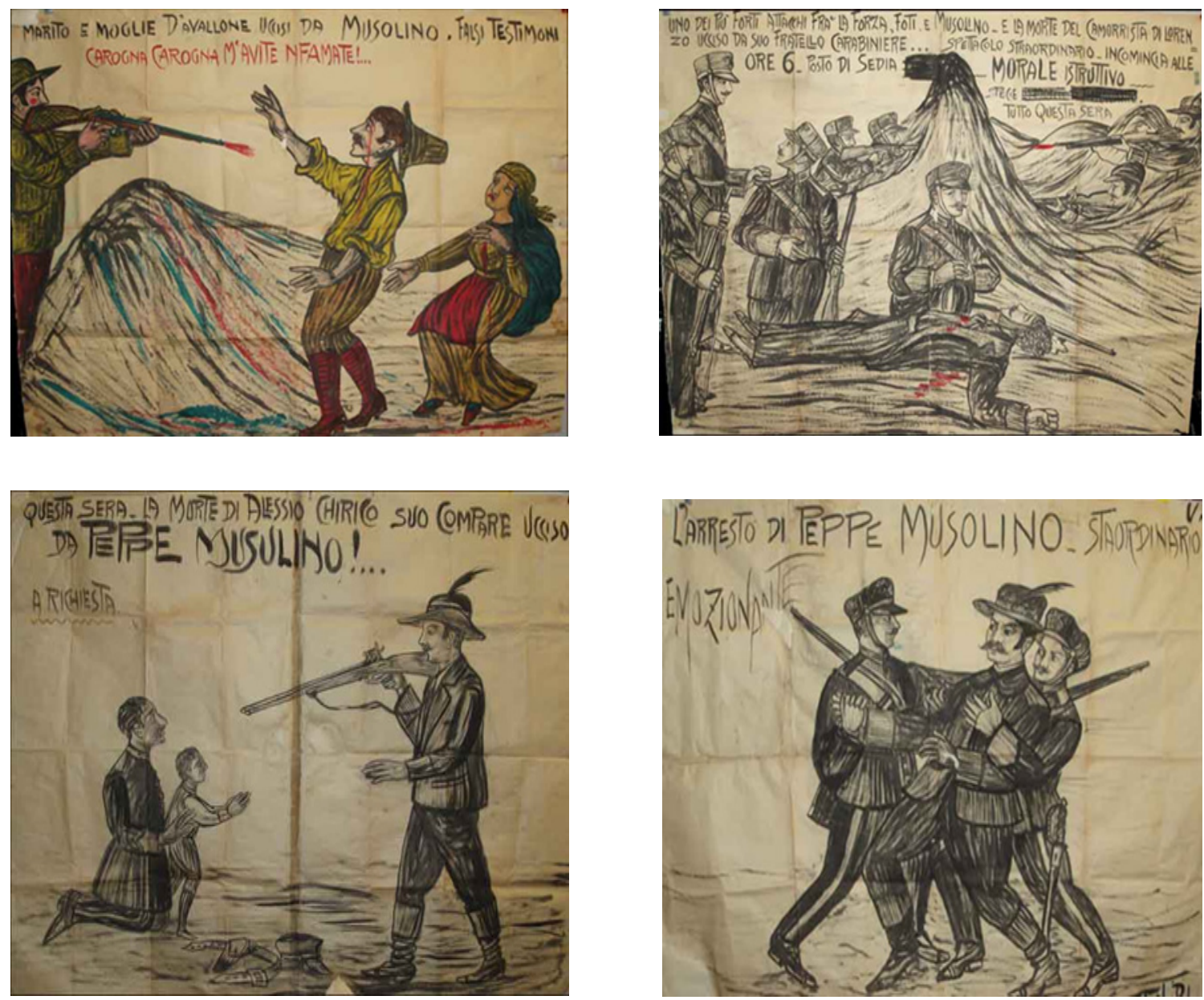

Figure 5. Enrico Morselli and Sante De Sanctis, Biografia di un bandito. Advertising posters on Musolino's legend for puppets shows staged by Calabrian pupari companies (puppeteers) in the 1910s-1920s.

promote serious discussion about the problems delaying the country's development. ${ }^{263}$

Prezzolini seemed to set the tone for a surge of energy among literati to reexamine the meaning of Italianità. 1918]), 10 .

${ }^{262}$ Giuseppe Prezzolini, Codice Della Vita Italiana (Rome: Biblioteca del Vascello, 1993 [orig 
My ideal of Italians is of men more practical, more severe, more educated, and more open to the vision of the great modern world. I feel that we could reach a deep spiritual upheaval in a short time: in a few generations. ${ }^{264}$

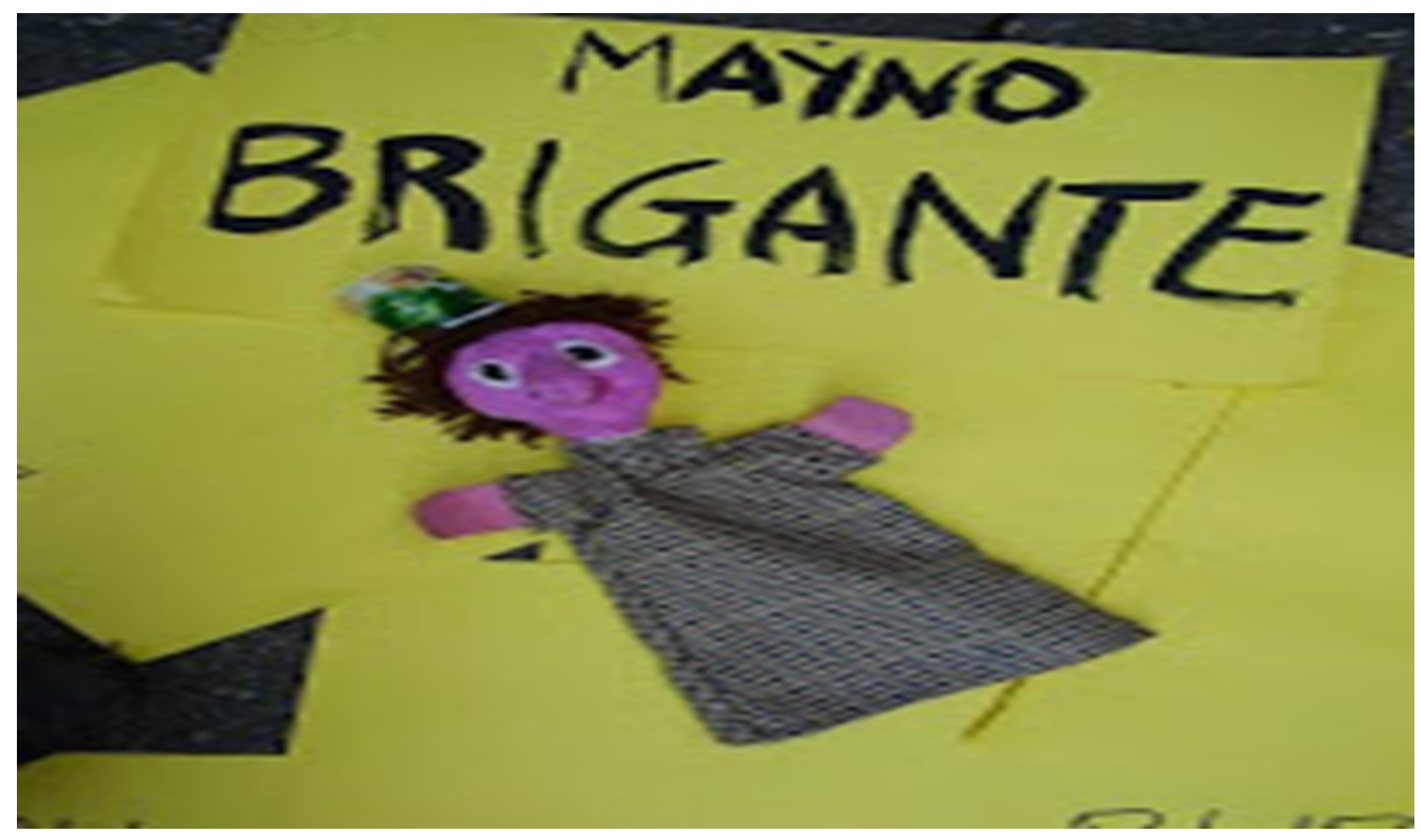

Figure 6. Mayno's legend interpreted and performed with marionettes created by students in an Italian school in 2009.

\section{A Nationalist Call to Italianità, 1915-1939}

Denunciation of the causes of Italy's backwardness added to criticism of the political establishment and contributed to the emergence of extremist right wing 1918]), 10 .

${ }^{263}$ Giuseppe Prezzolini, Codice Della Vita Italiana (Rome: Biblioteca del Vascello, 1993 [orig

264 'Il mio ideale d'italiani è quello di uomini più pratici, più severi, più colti, più aperti alla visione del grande mondo moderno. Sento che si potrebbe arrivar ad un profondo rivolgimento spirituale in breve tempo: in un paio di generazioni.” In Giuseppe Prezzolini, Codice Della Vita Italiana (Rome: Biblioteca del Vascello, 1993 [orig 1918]), 10 . 
nationalism. ${ }^{265}$ Since 1861 , liberal and moderate/leftist governments had led the country.

In the 1910s, discontent favored the emergence of national-patriotic discourses, which

opposed the ruling political class and the liberal Prime Minister Giovanni Giolitti (1842-

1928). ${ }^{266}$ Mindful of public opinion, and to pacify Italian nationalists, in 1911 Giolitti

ordered the declaration of war on the Ottoman Empire, of which Libya was a part, and

prepared to annex a portion of the North African territory to the "Kingdom of Italy.",267

Italian nationalists, who believed in the regenerating function of war, returned to the

${ }^{265}$ At the beginning of the twentieth century, Max Weber's ideas on Protestant ethic and capitalism reached Italy. Weber's ideas, elaborated by Sismondi and De Sanctis, influenced Gobetti's position on Catholicism and religion, and that of the contemporary intellectuals Amedeo Quondam and Mario Missiroli, and of the Protestant thinker Giuseppe Gangale. Giuseppe Gangale, Rivoluzione Protestante (Turin: Edizioni Gobetti, 1925); Amedeo Quondam, "Il Barocco e la Letteratura: Genealogie del Mito Della Decadenza Italiana," in I Capricci di Proteo. Percorsi e Linguaggi del Barocco (Rome: Salerno, 2002); Max Weber, Protestant Ethic and the Spirit of Capitalism, Piero Burresi (1931).

${ }^{266}$ Emilio Gentile, Il mito dello stato nuovo. Dal radicalismo nazionale al fascismo (Rome-Bari: Laterza, 1999 [orig 1982]); Robert Wohl, The Generation of 1914 (Cambridge: Harvard University Press, 1979). The idealist philosopher Giovanni Gentile (1875-1944) tied character to the idea of will and argued that the existence of a nation was demonstrated by the presence of a strong national will, which showed itself in particular in the determination with which a people fought in war. Giovanni Gentile, Guerra e fede (Bari: Laterza, 1919); Alberto Asor Rosa, La Cultura, Storia d'Italia, dall'unita`a oggi (Turin: Einaudi, 1975), 126.

${ }^{267}$ Italy arrived late to the "scramble for Africa", which saw France, Britain, Belgium, Germany, Portugal, and Spain occupy and colonize African countries between 1881 and 1914. In 1882, Italy occupied Eritrea and some territory on the south side of the horn of Africa. In 1887, the Italian Prime Minister Agostino Depretis (1813-1887) ordered an invasion of Ethiopia, which resulted in a defeat at Dogali, with the loss of five hundred Italian troops. With the Treaty of Wuchale in 1889, signed by the new Italian Prime Minister Francesco Crispi (1819-1901), Italians claimed that Ethiopia had become an Italian protectorate. The Ethiopian refusal to abide to the Italian interpretation of the terms of the Treaty of Wuchale brought to a new war in 1895, which saw the humiliating defeat for Italy at the hands of Ethiopian forces at the Battle of Adwa in 1896. To avoid exclusion from North Africa by Britain and France, in 1911 Italy declared war on the Ottoman Empire, of which Libya was part, and gained Libya and the Dodecanese Islands. 
themes of education and virile discipline that were debated at the close of the nineteenth century. These nationalists began to define the Italian character with a new jargon. ${ }^{268}$ Italianità became omnipresent in political discourse associated with words such as discipline, duty, personal sacrifice, virility, violence, faith and sincerity. ${ }^{269} \mathrm{~A}$ crescendo of calls to these principles mounted from the Manifest of Futurism published by Filippo Tommaso Marinetti (1874-1944) in 1909. The opening words of every article in the declaration were significant

We want to sing the love of danger; we affirm that the world has been enriched by the beauty of speed; we want to celebrate the man at the wheel; we are on the extreme promontory of the centuries; we want to glorify war; we want destroy the museums; we will sing of great crowds excited by work. [It] is from Italy that we launch to the world our manifesto of overwhelming violence... ${ }^{270}$

The words incited a rupture with the past and commanded change within Italy. The call to duty and sacrifice took Italians into World War I. ${ }^{271}$ According to the ideologues of

\footnotetext{
${ }^{268}$ Turiello, Mosso, Nicola Marselli, Edmondo De Amicis Giosue`Carducci $V$ Guido Baccelli ita Moderna Degli Italiani; Marselli, Gl'Italiani del Mezzogiorno; De Amicis, Cuore; Pasquale Turiello, Saggio Sull'educazione Nazionale in Italia (Napoli: Pierro, 1891); Guido Baccelli insisted on the virtues of 'ginnastica bella' (military gymnastics). Gaetano Bonetta, Corpo e Nazione. L'Educazione Ginnastica, Igienica e Sessuale Nell'Italia Liberale (Milan: Angeli, 1990).

269 "Programma politico futurista," Lacerba, October 15, 1913. Program signed by Marinetti (1876-1944), Umberto Boccioni (1882-1916), Carlo Carrà (1881-1966), Luigi Russolo (1883-1947); Giuseppe Prezzolini (1882-1982), "Facciamo la guerra," in La Voce 6, 16, 1914; Giuseppe Prezzolini, "Il paese è responsabile," in Lacerba, October 1, 1914.

${ }^{270}$ Filippo Tommaso Marinetti, “Manifesto del Futurismo,” Le Figaro, 20 febbario, 1909.

${ }^{271}$ When World War I started in August 1914, Italy did not enter the war, although it was part of the Triple Alliance with Austria-Hungary and Germany. Italy's rivalry with Austria-Hungary, however, led the Italian government to enter the war on the side of the Triple Entente (France, Great Britain, and Russia) in 1915. By fighting against the Central Powers, Italy had the goal of liberating and annexing the regions that the 1815 Congress of Vienna had granted to the Austrian Empire. It was also a political strategy to pacify the internal radical nationalist political movement of the "irridentisti", which claimed the territories controlled by Austria Hungary.
} 
nationalism; the Libyan war had not regenerated the Italian character. So the new war was the solution that Marinetti and the ideologues of those years extolled so as to haul Italy out of its political and economic stagnation to modern dynamism, both nationally and internationally. If the idea of regeneration through war was not new, the language of war had taken on new meaning. With the emergence of an aggressive political movement that supported nationalist and imperialist assertions, the language became violent and gendered with a sense of ineluctability and urgency. In this political arena, journalists and politicians often collaborated. ${ }^{272}$ Their arguments supported the rhetoric of fascism and informed its endeavor to remake the Italian character. ${ }^{273}$ Intellectuals from a broad spectrum of political orientations, including Catholics, called for intervention in World

\footnotetext{
${ }^{272}$ The first organ of the new imperialist nationalism was Enrico Corradini's "Il Regno", a weekly published in Florence. The journal attacked the ineptitude and weakness of the Italian bourgeoisie, a class in decline and incapable of pursuing an aggressive colonial policy to assert the role of Italy in the world and saving it from the threat of socialism. Enrico Corradini, "Vecchio e Nuovo Nazionalismo," Il Regno (1914); Giuseppe Prezzolini, "Le Due Italie," La Voce (1904). Before founding "La Voce", Prezzolini had worked for Corradini's journal and had written on the old rhetoric of the two Italies, but not in terms of north-south divide, but as a binary action/progress versus inaction/stagnation. "Il Regno", as "La Voce" also advocated a "more masculine" Italian leadership, but in "La Voce" Prezzolini's criticism widened to target Italy and the Italian people, whom, he accused, had a pale sense of duty, suffered of lack of initiative, had a pale sense of duty and "a weak sensitivity to dirt". Here we read the the ethical moral sphere of the intellectual and the middle-class dislike for attitudes characteristic of an agricultural society, and Prezzolini's contempt for the habits of the popular classes. Giuseppe Prezzolini, "Ventiquattr'ore in Italia," La Voce (1910). In some of the articles published in La Voce readers could perceive the conservative preoccupation with the growing strength and militancy of the labor movement. See Giovanni Papini, "Ritratto del Carducci," La Voce (1909).

${ }^{273}$ Barbara Spackman, Fascist Virilities: Rhetoric, Ideology, and Social Fantasy (Minneapolis and London: University of Minnesota Press, 1996); Giuseppe Prezzolini, Italia 1912. Dieci Anni di Vita Intellettuale, $<$ ed $>$ Simonetti, C. M. (1912).
} 
War I. ${ }^{274}$ Unfortunately, however, war did not bring glory to Italy, nor did it unify Italians.

A new polarity came to characterize Italians in the first two decades of the twentieth century. The results of World War I reinforced the images of shrewd and foolish Italians (furbi and fessi), a contrast that the literature of the period amply covered. $^{275}$ World War I offered intellectuals the occasion to articulate new images of a still split Italianità. Italian psychologists studied the national subconscious and Catholic priests observed soldiers' behavior with a paternalistic concern for the "peasant" soldiers from North and South. Following with the Catholic line of argument, the soldiers were described as attached to the family and very close to the Church. ${ }^{276}$ On the outcome of the war, the Italian élite took different positions. Some attributed the responsibilities of the 1917 Italian defeat at Caporetto to the nature of the Italian people (and, by extension, its soldiers); others used the Italian army's resistance along the Piave River and at Monte

\footnotetext{
${ }^{274}$ Giovanni Gentile, Guerra e Fede (Bari: Laterza, 1919); Silvana Patriarca, Italian Vices: Nation and Character from the Risorgimento to the Republic (Cambridge: Cambridge University Press, 2010), 118-9; E. Scaglione and B. Chiara, ed.s, L'Impresa Libica. Italia Vittoriosa. Antologia Delle Piú Belle Pagine (Naples: Bideri, 1917); Giuseppe Prezzolini, "Dopo un Anno," La Voce (1912); Schipio Sighele, "Quello Che Abbiamo Compiuto," Primavera Italica (1911).

${ }^{275}$ Shrewd-foolish jokes frequently recurred in collections of aphorisms, as in Giuseppe Prezzolini, Codice della vita italiana (Rome: Biblioteca del Vascello, 1993 [orig 1918]). Aphorisms were very popular in Europe in these years. See Oscar Wilde, Epigrams and Aphorisms (Boston: J.W. Luce, 1905); Jeffrey T. Schnapp, "Program of the National Fascist Party," in A Primer of Italian Fascism (Lincoln and London: University of Nebraska Press, 2000). Silvana Patriarca wrote that the category of the "furbi" existed before WWI, and quotes De Sanctis'critique of the Decameron. She argues, however, that the opposition "furbi" and "fessi" emerged with the war, and that the latter entered the Italian language from the Neapolitan dialect. In Silvana Patriarca, Italian Vices: Nation and Character from the Risorgimento to the Republic (Cambridge: Cambridge University Press, 2010), 124.

${ }^{276}$ G. C. Ferrari, "Osservazioni sui feriti della nostra guerra," Rivista di Psicologia 11 (1915): 184-217; Agostino Gemelli, Il nostro soldato. Saggi di psicologia militare (Milan: Treves, 1917).
} 
Grappa, and the allied victory at Vittorio Veneto as evidence of the much needed redemption and proof of Italian valor. ${ }^{277}$ For these authors, soldiers in the trenches were foolish (fessi). Officials were shrewd (furbi). ${ }^{278}$ Soldiers may have agreed with the judgment but they complained that the allegedly shrewd officials were, in fact, cowards. On July 7, 1917 the Military Court condemned soldier Giosué M. to twelve years of imprisonment for insubordination. He had refused to obey the order to advance and had yelled "These cowards. They want to kill us, I cannot walk anymore. Try to get me to do another step forward!"279 Soldier Arturo Botta, a miner from Como, was condemned to sixteen years for the same crime. Not only did he disobey military orders, he also threatened his superior: "Captain, you are a coward; try to send us in the trenches one more time, and I'll kill you. ${ }^{, 280}$ Another 23 year old miner declared to the military justices at the military tribunal that he had chosen to be in hiding in order to find a way to emigrate, rather than continuing to fight. ${ }^{281}$ Desertions were frequent: 28 percent of soldiers from the North and 47 percent of soldiers from the South declared that they had

\footnotetext{
${ }^{277}$ Giovanni Gentile still argued that Italian soldiers' participation to the war remained fundamental for making Italians into a unified people. Giovanni Gentile, "La Colpa Comune," Il Resto del Carlino (1918). 1918]).

${ }^{278}$ Giuseppe Prezzolini, Codice della vita italiana (Rome: Biblioteca del Vascello, 1993 [orig

279 "Questi vigliacchi ci voglion far morire; io non cammino più. Si provi lei a farmi fare un passo in avanti." In ACS, Tribunali Militari (TM), Tribunale militare del XX corpo d'armata.

280 "Capitano, sei un vigliacco; [...] se ci porti n'altra volta in trincea, ti faccio la pelle." In ACS, TS, AD, b. 5 (104), May 25, 1918.

${ }^{281}$ ACS, TS, AD, b 11 (110), August 28, 1917.
} 
deserted in order to help their families. ${ }^{282}$ The war was fought on the Northern front, an unfamiliar environment for Southerners. This circumstance and the fact that, differently from the soldiers from South, Northerners knew the enemy whom they were fighting, may account for the North-South difference in the number of deserters. ${ }^{283}$ Sometimes soldiers on the opposing sides tacitly established tactics of survival: "We did not want war; the gentlemen who wanted it, they had to fight it. ... We were shrewd-we respected each other." ${ }^{284}$ Shrewd and foolish: the two terms entered the Italian everyday language and revealed meanings attributed to the terms. Shrewd (furbo) was at the same time an object of resentment and condemnation as well as someone to envy and imitate. ${ }^{285}$ Soldiers from North and South Italy had no sense of patriotism and loyalty to the idea of Italy. They were not buying into the concept of Italianità and a gulf of opposing ideals further separated soldiers. National identity still remained an aspiration to establish.

In the 1920s and 1930s the issue of what constituted authentic Italian identity assumed a prominent role in the political discourse. Theorists of fascism discussed Italian identity seeking to define what they believed made the Italians unique and superior as a

\footnotetext{
${ }^{282}$ Bruna Bianchi, "I disobbedienti nella grande guerra," in La follia e la fuga. Nevrosi di guerra, diserzione e disobbedienza nell'esercito italiano 1915-1918 (Roma: Bulzoni, 2001), 12.

${ }^{283}$ In 1915, when Italy entered World War I, Austria still occupied the Northeastern region of Italy.

284 "La Guerra l'avevamo mica voluta né loro né noi: che venissero a farla quei siori che l'avevano voluta. [...]. Ci rispettavamo, ma da furbi." See Lucio Fabi, "La grande guerra sul Carso attraverso i diari, le memorie, le testimonianze dei protagonisti," Qualestoria 12 (1986).

${ }^{285}$ Silvana Patriarca, Italian Vices: Nation and Character from the Risorgimento to the Republic (Cambridge: Cambridge University Press, 2010), 124.
} 
people. Fascist intellectuals contrasted Italy, with its "solar" and "Mediterranean" character, to the culture and identity of "Nordic" Europe, and celebrated the greatness of Roman civilization from which the Italians descended. They contended that Roman civilization owed its greatness to its Mediterranean roots. ${ }^{286}$ Nonetheless, this complacent celebration of Mediterranean Italianness contrasted with Mussolini's intention of remaking the Italians, a contrast that historian Silvana Patriarca reads as a complex of inferiority or inadequacy. ${ }^{287}$ Most striking in fascist nationalism, even more than in Risorgimento patriotism, was the belief in the superiority of Italy, which nonetheless was always paired with the conviction that Italians needed to be regenerated. Mussolini's contribution to popularize elements of fascist rhetoric (anti-liberal establishment and the construction of a virile and militarized national character) was significant, as Mussolini was the most prepared to reach the masses with his propaganda apparatus.

Such rhetoric fueled fascist propaganda that advocated anti-liberal ideologies and the construction of a virile and militarized national character. ${ }^{288}$ Mussolini's propagandists declared that fascism intended to restore the warrior tradition of the Italian

\footnotetext{
${ }^{286}$ Silvana Patriarca, Italian Vices: Nation and Character from the Risorgimento to the Republic (Cambridge: Cambridge University Press, 2010), 158-9.

${ }^{287}$ Silvana Patriarca, Italian Vices: Nation and Character from the Risorgimento to the Republic (Cambridge: Cambridge University Press, 2010), 159.

${ }^{288}$ Barbara Spackman, Fascist Virilities: Rhetoric, Ideology, and Social Fantasy (Minneapolis and London: University of Minnesota Press, 1996); Giuseppe Prezzolini, Italia 1912. Dieci Anni di Vita Intellettuale, $<$ ed $>$ Simonetti, C. M. (1912).
} 
race and return strength and virility to the people. ${ }^{289}$ They were not just mandolinstrummers, the stereotyped characters that foreigners thought of them. ${ }^{290}$ Mussolini summarized Italy's history describing the "terrible centuries of political, military, moral decadence from 1600 to the rise of Napoleon" when foreign powers had weakened Italians' character and mentality. ${ }^{291} \mathrm{He}$ was also critical of the Risorgimento because it had not succeed in returning the Italian people to greatness. ${ }^{292}$ He intended to resume and accomplish this goal, as his following speech indicates.

The Italians of the twentieth century resumed, between 1914 and 1918, under Your Majesty's command, the march which Garibaldi broke off at Bezzeca in 1866 with his laconic and dramatic 'I obey' and they have continued it to the Brenner, Trieste, Fiume, Zara, the peak of the Nevoso, the opposite shore of the Adriatic. The Blackshirts, who knew how to fight and die during the years of humiliation, also stand politically in a line of descent from the Redshirts and their leader. ${ }^{293}$

\footnotetext{
${ }^{289}$ Mino Maccari, “Squadrismo. Battagliero Fascista,” Il Selvaggio (1924); Benito Mussolini, Opera Omnia, Opera Omnia (Florence: La Fenice, 1951-78).

${ }^{290}$ Benito Mussolini, Opera Omnia, Opera Omnia (Florence: La Fenice, 1951-78).

${ }^{291}$ Benito Mussolini, Opera Omnia, Opera Omnia (Florence: La Fenice, 1951-78).

${ }^{292}$ Benito Mussolini, Opera Omnia, Opera Omnia (Florence: La Fenice, 1951-78). Historian
} Silvana Patriarca noted the contradiction in fascist rhetoric, which juxtaposed a narcissistic tone evoking the linkage with the Roman past with flaws in Italian character.Silvana Patriarca, Italian Vices: Nation and Character from the Risorgimento to the Republic (Cambridge: Cambridge University Press, 2010), 134; Renzo De Felice, Mussolini Il Duce, Lo Stato Totalitario, 1936-1940 (Turin: Einaudi, 1981); Renzo De Felice, Mussolini Il Duce, Gli Anni del Consenso, 1926-1936 (Turin: Einaudi, 1974); Emilio Gentile, La Grande Italia. Ascesa e Declino del Mito Della Nazione Nel Ventesimo Secolo (Milan: Mondadori Editore, 1997).

${ }^{293}$ Benito Mussolini, “Epopea Garbaldina,” in Epopea Garibaldina, vol. 25 of Il Popolo d'Italia, Susmel E. and Susmel D., Il Popolo d'Italia (Florence: La Fenice, 1932), 108-11. 
Mussolini recurred to the conventional tropes of nationalistic rhetoric. He first evoked idealized interpretations of the past and the symbol of Italian resurgence; then juxtaposed these memories with amplified representations of a humiliated present; finally he launched the depiction of an ideal future condition

All his life his heart was enflamed by one passion: 'the unity and the independence of the Fatherland'. ${ }^{29}$

Narratives of decline and redemption were crucial to nationalist agendas. Mussolini also knew the importance of linking redemption to political mobilization and to the construction of a communal identity. Mussolini repeated the three themes of nationalist rhetoric time and time again. He was obsessed by what he believed were the dismaying images of Italian emigrants to foreign countries, and by the stereotypical images of Italians as organ grinders and mandolin-strummers that were created in the foreign tourists' imagination. He abhorred the commonplaces that associated Italy with indolence (dolce far niente). Mussolini and his followers soon set to work to create the Italian nation as a community inhabited by "hard-working" people, governed by the ideal leader, "il condottiero ideale", a true Roman, the Renaissance man, and the Italian Napoleon. ${ }^{295}$

Fascism staged Romanità, a far reaching exercise that evoked a sense of state,

${ }^{294}$ Benito Mussolini, "Epopea Garbaldina," in Epopea Garibaldina, vol. 25 of Il Popolo d'Italia, Susmel E. and Susmel D., Il Popolo d'Italia (Florence: La Fenice, 1932), 108-11.

${ }^{295}$ Benito Mussolini, Opera Omnia, Opera Omnia (Florence: La Fenice, 1951-78); Benito Mussolini, Opera Omnia, Opera Omnia (Florence: La Fenice, 1951-78); Benito Mussolini, Opera Omnia, Opera Omnia (Florence: La Fenice, 1951-78); Luigi Passerini, Mussolini Immaginario. Storia di una Biografia, 1915-1939 (Rome-Bari: Laterza, 1991); Giuseppe Prezzolini, Benito Mussolini, Giuseppe Prezzolini e La Voce, Emilio Gentile (Florence: Sansoni, 1976 [orig 1924]); A Giardina and A. Vauchez, Il Mito di Roma: Da Carlo Magno a Mussolini (Roma-Bari: Laterza, 2000). 
order, and authority. The regime chose to inscribe this discipline everywhere, extended it to the social and political body, in the material environment and in fascist iconography. The Roman symbol of unity and authority, depicted as bundles of rods flanked by an ax, was appropriated as the main symbol of the regime. ${ }^{296}$ Romanità formed the basis for the power and strength of the state and was the template through which Mussolini thought the new Italy should be modeled. But Romanità not only represented a new political religion, it also meant a defense against what was described in 1925 as the new "barbaric ideologies, German Judaic, of individualism, materialism and anarchy" as well as the threat of American hegemony. ${ }^{2297}$ To the threat of American hegemony, the fascist regime also reacted with 'ruralist' theories arguing that peasants, and not the unruly industrial workers, were the bearers and natural defenders of the true Italian identity. ${ }^{298}$ The preference granted to everything "rural" did not mean that fascism rejected modernity in its entirety. It selected those aspects, such as modern industry and technology that fitted its project and the interests of its supporters, and eliminated those of liberalism and democracy that did not.

To the Fascists, ruralism meant primarily the rejection of an urban culture that they associated with cosmopolitan values and sterility, and the search for a true and

\footnotetext{
${ }^{296}$ Andrea Giardina and André Vauchez, Il mito di Roma: da Carlo Magno a Mussolini (RomaBari: Laterza, 2000).

${ }^{297}$ As Francesco Coppola declared in an article published in a 1925 issue of Politica, the journal of the nationalists who merged with the Fascist Party in 1923.

${ }^{298}$ D. G. Horn, Social Bodies: Science, Reproduction, and Italian Modernity (Princeton: Princeton University Press, 1994).
} 
purely Italian identity, uncontaminated by foreign influences. ${ }^{299}$ Italy carried the banner of the "resurgent latinità. ${ }^{300}$ Fascists embraced dualism: ruralism and modernity. Hence, a further meaning for Romanità became not just or not only conservation or a return to the values of the past, but the means through which fascists promoted the revolutionary nature of their regime. For Mussolini the cult of Rome was not a worship of past greatness for its own sake, but a myth for the reshaping of Italian society. Mussolini intended to make the Italians the "Romans of modernity" namely "a nation forged according to the militarist model of the 'citizen-soldier'., ${ }^{301}$ In 1937, an exhibition was held to celebrate the bimillenial year of the birth of Emperor Augustus (63 BC-AD14). In his introduction to the exhibition catalog, Mussolini reworked the themes he repeated often

Rome is our starting point and reference, is our symbol or, if you want, our myth. We dream of a Roman Italy that is wise and strong, disciplined and imperial. Much of what was the immortal spirit of Rome is reborn in fascism: Roman are the fasces, Roman our organization of soldiers, Roman our pride and our courage. Civis romanus sum. ${ }^{302}$

${ }^{299}$ D. G. Horn, Social Bodies: Science, Reproduction, and Italian Modernity (Princeton: Princeton University Press, 1994).

${ }^{300}$ Giardina and Vauchez, Il Mito di Roma, 226.

${ }^{301}$ Emilio Gentile, "La Nazione del Fascismo. Alle Origini del Declino Dello Stato Nazionale," in Nazione e Nazionalità in Italia. Dall'alba del Secolo Ai Nostri Giorni, Giovanni Spadolini (Milan: Angeli, 1994), 87, quoted in Silvana Patriarca, Italian Vices: Nation and Character from the Risorgimento to the Republic (Cambridge: Cambridge University Press, 2010), 149.

302 "Roma è il nostro punto di partenza e di riferimento, è il nostro simbolo o se si vuole il nostro mito. Noi sognamo l'Italia romana cioè saggia e forte, disciplinata e imperiale. Molto di quello che fu lo spirito immortale di Roma risorge nel fascismo: romano è il littorio, romana la nsotra organizzazione di combattenti, romano il nostro orgoglio e il nostro coraggio. Civis romanus sum." See Giulio Quirino Giglioli, Mostra Augustea Della Romanità, 1937-1938, catalog (Rome: Casa editrice C. Colombo, 1937), 369. 
References to Romanità abounded in the regime, to the point that some felt they had been reduced to an "empty and rhetorical slogan," as the racist theorist Julius Evola (18981974) complained on the pages of "Carattere." "Romanità," he wrote, should mean "to bring back to light qualities that had belonged to the Romans," such as "sobriety." Evola also raised the problem of adopting Rome as a model. He noted that one could only look up to early Rome and to Republican Rome, but certainly not to the era of "decadence," especially since the latter represented a racially-mixed society, a concept from which fascists recoiled. ${ }^{304}$ But Romanità was an essential narrative for Fascism. By staging Romanità, Fascists intended to shape the identity that was necessary to their idea of nation.

To the repetitive narrative of a glorious past, a degraded present, and a redeeming future, Fascism soon added another recurring theme: the themes of "two Italys" and "two Italians". Mussolini compared the healthy Italy of producers (of vigorous people, of courage, of wealth) with the old Italy, "the putrified Italy" created by the older and "rotten" political class. ${ }^{305}$ The others, whom the fascist regime wished to erase from the

${ }^{303}$ Julius Evola, "Riscoprire la romanità," Carattere 2 (1942).

${ }^{304}$ Julius Evola, "Riscoprire la romanità," Carattere 2 (1942); Emilio Gentile, "La nazione del fascismo. Alle origini del declino dello stato nazionale," in Nazione e nazionalità in Italia. Dall'alba del secolo ai nostri giorni, Giovanni Spadolini (Milan: Angeli, 1994), 87.

${ }^{305}$ Mussolini, Opera Omnia, 74; For Mussolini's biographer Renzo De Felice, Mussolini’s insistence on changing the Italian character characterized the late 1920s and 1930s, and inspired fascist writers, mainly journalist, who dealt with the topoi of "the new Italian" in their articles: Leo Longanesi (director of the journal "L'Italiano"), Nello Quilici (director of the journal "Corriere Padano"), Curzio Malaparte, Giuseppe Bottai (director of the journal "Critica Fascista"), and Mino Maccari (director of the journal "Il Selvaggio"). 
script of the new Italy, were the "old Italians" of liberal Italy and the bourgeoisie, from North and South Italy. In the period from 1935 to 1937, in order to avoid contradiction, Mussolini had to abandon the North-South diatribe, the Aryan-Mediterranean dualism. He chose bourgeois as term of negative comparison to the ideal Italian. "Bourgeoisie" came to represent a spectrum of definitions that little had to do with the identification of the middle class or this class' conventional values. Members of the lower classes, homosexuals, the Jews, became bourgeois. Mussolini's former belief in the Mediterranean paradigm that granted greatness to the Italian character collapsed in the 1938 promulgation of the Italian racial laws against Jews and the non-Italian inhabitants of the Italian colonies. Mussolini’s alliance with Hitler in 1938 forced the fascist regime to return to a racial classification of Italians. ${ }^{306}$ Fascist Italy opened again to naturalist Jean Louis Armand de Quatrefages (1810-92)'s theories of two races inhabiting the Italian peninsula as mentioned in the first part of this chapter. ${ }^{307}$ Obviously, given Hitler's influence, the Aryan stock living in the North allegedly had better qualities than the Italic stock predominant in the South. Unfortunately for Mussolini and his supporters, the 1937 setbacks in Spain and the difficulties that Italy was also facing in Greece (1940), Libya, and Ethiopia (1941) effaced their envisioned picture of a virile and militarized

\footnotetext{
${ }^{306}$ Aaron Gillette, Racial Theories in Fascist Italy; Evola, "Riscoprire la Romanità"; Francesco Germinario, Razza del Sangue, Razza Dello Spirito. Julius Evola, l'Antisemitismo e Il Nazionalsocialismo, 1930-1943 (Turin: Bollati Boringhieri, 2001); Mario Toscano, "Marcello Ricci. Una Testimonianza Sulle Origini del Razzismo Fascista,” Storia Contemporanea 27 (1996).

${ }^{307}$ Jean Louis Armand Quatrefages, Histoire Générale Des Races Humaines (Paris: A. Hennuyer, 1886-1889). See also Giuseppe Sergi, Arii e Italici. Attorno all'Italia preistorica (Turin: Bocca, 1898).
} 
Italy. The "new Italian," the invented fascist character of the "hyper-italian", (arcitaliano), crumbled along with the Italian armed forces.

The question of Italianità was also central to anti-fascist opposition indicating an important contention. ${ }^{308}$ The following paragraphs explore the question of how the conception of race could so easily and so continually be made a reference point and represent a symbolic-semantic universe of indicators that have been thoroughly used and theatrically enacted by opposite ideologies. Anti-fascists imagined Italians differently from fascists and they made no reference to ethnic-racial components nor to the psychology of peoples. ${ }^{309}$ In the 1920s, Mussolini’s opponents argued that Italian indolence was an insulting legend but that it had some foundations because, in the depth of their souls, Italians harbored skepticism and an inferiority complex. ${ }^{310}$ Since they were

308 The advancement of the new right-wing movement and the failure of the "red" project convinced Gramsci that Italians had peculiar specific traits that forced them into backwardness. Only a disciplined and truly revolutionary labor movement could hope to reform and realize the much needed moral and intellectual reform in a communist context. Antonio Gramsci, "Lo Stato Operaio," L'Ordine Nuovo, 1921-1922 (1921); Antonio Gramsci, "Apoliticismo," in Quaderni del Carcere (Turin: Einaudi, 1952); Antonio Gramsci, "Quaderni del Carcere," in Vol. III, V. Gerratana (Turin: Einaudi, 1934); Antonio Gramsci, "Caratteri Italiani," in Scritti Giovanili, P. Spriano (Turin: Einaudi, 1972 [orig 1914-1918]); Antonio Gramsci, "La Settimana Politica," L'Ordine Nuovo (1919).

${ }^{309}$ Pietro Gobetti, "Elogio Della Ghigliottina," La Rivoluzione Liberale (1922); Augusto Monti, "Attivo e Passivo Sulla Burocrazia," La Rivoluzione Liberale (1922); Giustino Fortunato, "Dopo la Guerra Sovvertitrice," in Scritti Politici, F. Barbagallo (Bari: De Donato, 1981 [orig 1921]); Giovanni Ansaldo, "Grandezza e Decadenza del Perfetto Italiano," La Rivoluzione Liberale (1924); Giovanni Ansaldo, “Mussolinismo," La Rivoluzione Liberale (1923); Natalino Sapegno, "Il Piemonte e le Province," La Rivoluzione Liberale (1922).

${ }^{310}$ Carlo Rosselli, Socialismo Liberale (Rome, Florence, Milan: Edizioni U, 1945); Carlo Levi, "Seconda Lettera Dall'Italia," in Quaderni di Giustizia e Libertà (1932); Giuseppe Antonio Borgese, "Letter to Carlo Rosselli," Giustizia e Libertà e Il Socialismo Liberale (1935); Giuseppe Antonio Borgese, Goliath: The March of Fascism (New York: Viking Press, 1937); Benedetto Croce, Pagine Sulla Guerra (Bari: Laterza, 1928); Benedetto Croce, Storia d'Italia 1871-1915 (Milano: Adelphi, 1991 [orig1928]); Benedetto Croce, Teoria e Storia Della Storiografia (Bari: Laterza, 1943 [orig 1920]); Carlo Sforza, L'Âme Italienne (Paris: Flammarion, 1934); Carlo Sforza, Les Italiens Tels Qu'ils Sont (Montreal: Editons de 
not able to become a nation at the end of the Middle Ages, like many other European countries, Italians relied exclusively on their families and on the social network within their reach to build a community where they were free and safe. These communities harbored indulgence. Here, people traded forgiveness for one's sins for easy obedience. ${ }^{311}$ Writer Carlo Levi (1902-75) wrote that many Italians embraced fascism for its organization because they had inherited the medieval, communal mentality, and with it the inability to be free. ${ }^{312}$ For anti-fascists, Italians were responsible for their own adversities; they had to stop talking about rebirth and resurgence, praising their past and complaining about their weaknesses. They should concentrate instead on getting the moral and political education that they lacked to finally live as adults.

Inventing Italianità was impossible because Italy and Italians existed and could not be "re-made" according to abstract plans. Italians are what their history says about

l'Arbre, 1941); Gaetano Salvemini, "Gl'italiani Come Veramente Sono: Studio di Psicologia Europea," in L'Italia Vista Dall'America, Tagliacozzo. E. (Milan: Feltrinelli, 1942); Gaetano Salvemini, "Lezioni da Harvard. L'Italia Dal 1919 al 1929,” in Scritti Sul Fascismo, R. Vivarelli (Milan: Feltrinelli, 1963).

\footnotetext{
${ }^{311}$ The Turinese journalist Piero Gobetti (1901-26) took for granted that the Italian character was an impediment to modern political life. He believed that Catholicism, which dominated the Italian mentality hindered progress. For Gobetti, Catholicism took the place of national myth, which was missing in Italy because Risorgimento had had only the appearance and not the reality of a revolution. In few words, Gobetti pointed to the 'original sin' of the Italian state, namely its being the result of 'royal conquest' in the midst of the weakness of revolutionaries and the inertia and passivity of the people. The attitudes of the élites in the 1860s and 1870s had impeded full modernization of the country and the unfolding of a 'true' political struggle. Gobetti read the rise of fascism as a coup d'etat realized by an oligarchy without any serious culture and unable to construct in Italy a modern conscience. In Norberto Bobbio, Italia Fedele. Il Mondo di Gobetti (Florence: Passigli, 1986); Norberto Bobbio, Ideological Profile of Twentieth-Century Italy (Princeton: Princeton University Press, 1995).

312 Carlo Levi, "Seconda Lettera Dall'Italia," in Quaderni di Giustizia e Libertà (1932), 17.
} 
them. Such was the argument of philosopher Benedetto Croce. ${ }^{313}$ Clarifying his statement, he wrote, "What is the character of a people? Their history, all their history, and nothing else but their history." ${ }^{314}$ Anti-fascist intellectuals, who agreed with Croce, attacked the theories concerning the weaknesses of Latin peoples, and the negative selfevaluation that Italians had inflicted upon themselves since their unification. They questioned how Italians (or at least the political élite), could support the idea of "nation" if they, as people, did not believe they possessed positive qualities. ${ }^{315}$ They agreed that only historians could become judges of a people's character and argued that fascism had nothing in common with the Italian soul. Diplomat Carlo Sforza (1872-1952), in particular, argued that not Rome, but the Italian "cities" were the essence of Italianità. Not Rome, the metropolis of antiquity, but the cities at the periphery; not the Roman Empire but a reproduction of the fragmented Greek polis modeled Italian character. To support his thesis, he referred to the persistence of dialects and the Italian predilection for local traditions. The Italian regionalism proposed by Sforza aimed to free the image of

${ }^{313}$ Benedetto Croce became anti-fascist in 1925, one year after socialist and deputy to the Italian government Giacomo Matteotti (1885-1924) was murdered. In the same year, he also broke his friendship with Giovanni Gentile. Benedetto Croce, Pagine Sulla Guerra (Bari: Laterza, 1928); Benedetto Croce, Storia d'Italia 1871-1915 (Milano: Adelphi, 1991 [orig1928]); Benedetto Croce, Teoria e Storia Della Storiografia (Bari: Laterza, 1943 [orig 1920]).

314 “Che cos'è il carattere di un popolo? La sua storia, tutta la sua storia e nient'altro che la sua storia.” See Benedetto Croce, Storia d'Italia 1871-1915 (Milano: Adelphi, 1991 [orig1928]).

${ }^{315}$ Diplomat Carlo Sforza (1872-1952) and historian Gaetano Salvemini (1873-1919) agreed with Croce, and criticized the generalization that associated fascism with Italian character. Carlo Sforza, $L$ 'A $\hat{A}$ e Italienne (Paris: Flammarion, 1934); Carlo Sforza, Les Italiens Tels Qu'ils Sont (Montreal: Editons de l'Arbre, 1941); Gaetano Salvemini, “Gl'italiani Come Veramente Sono: Studio di Psicologia Europea," in L'Italia Vista Dall'America, Tagliacozzo. E. (Milan: Feltrinelli, 1942); Gaetano Salvemini, "Lezioni da Harvard. L'Italia Dal 1919 al 1929,” in Scritti Sul Fascismo, R. Vivarelli (Milan: Feltrinelli, 1963). 
Italians from the clutches of fascism because it pointed not to imperial Rome, but to a pre-Roman past that nourished Italian individualistic preference for municipal autonomy. $^{316}$ A regional Italianità had proved fascism wrong. Carlo Sforza chose to live abroad, in France until 1940 when he moved to the United States. In the 1920s and 1930s, the Italian groups who opposed fascism were engaged in finding theories that could disassociate the image of the Italian people from that of the fascist regime. Their intent was to free the image of the country from fascism. Dissenting intellectuals were forced to leave. Historian Gaetano Salvemini (1873-1957) also migrated to the United States when Mussolini rose to power. ${ }^{317}$ Sixty years had passed since the birth of the Kingdom of Italy, and Italianità was still a contentious notion.

\section{Conclusion}

Between 1900 and 1920, when millions of Italians were leaving their country and migrating in large numbers to other European countries and to the United States in search of work, the image of the indolent Italians weakened. The Italian emigrants' remittances proved their hard labor in foreign countries. Foreign loans had financed two-thirds of Italy's trade deficit in 1890; in the years before World War I, Italy's exports amounted to

\footnotetext{
${ }^{316}$ Carlo Sforza, L'Âme Italienne (Paris: Flammarion, 1934); Carlo Sforza, Les Italiens Tels Qu'ils Sont (Montreal: Editons de l'Arbre, 1941).

317 Gaetano Salvemini, “Gl’italiani Come Veramente Sono: Studio di Psicologia Europea,” in L'Italia Vista Dall'America, Tagliacozzo. E. (Milan: Feltrinelli, 1942); Gaetano Salvemini, "Lezioni da Harvard. L'Italia Dal 1919 al 1929," in Scritti Sul Fascismo, R. Vivarelli (Milan: Feltrinelli, 1963).
} 
only $60-80$ percent of its imports. ${ }^{318}$ Yet, not only did the country enjoy a steady currency and low interest rates, but also after 1900, remittances balanced out foreign loans and Italy's spending on imported foreign goods. ${ }^{319}$ From 1901 to 1913, Italy’s commercial deficit was matched by credit. More than half the credit came from remittances. ${ }^{320}$ Migration was a decisive factor in Italy's favorable balance of payments. Even authors who had used the rhetoric of the effeminate character of the Italians changed their position. ${ }^{321}$ Through their hard work, Italians were disproving "the legend of indolence."

The opinion as to Italians held by observers in Europe and in the United States, however, was shaped by racial theories, fears of anarchism and socialism and nativist reactions to the great immigration of the turn of the century. Italians appeared as "undisciplined Southerners bent on crime and political subversion and lacking in the qualities necessary for democracy”. ${ }^{322}$ Anne O'Hare (1882-1954), a Catholic journalist

${ }^{318}$ Mark I. Choate, Emigrant Nation: The Making of Italy Abroad (Cambridge and London: Harvard University Press, 2008), 77.

${ }^{319}$ Mark I. Choate, Emigrant Nation: The Making of Italy Abroad (Cambridge and London: Harvard University Press, 2008), 77.

${ }^{320}$ Mark I. Choate, Emigrant Nation: The Making of Italy Abroad (Cambridge and London: Harvard University Press, 2008), 77.

${ }^{321}$ Physiologist Angelo Mosso (1846-1910) changed his mind on the wake of the newly found optimism of the early Giolittian age. Re-reading Burckhardt, Mosso exalted Renaissance Italians as the "great masters of individualism" while attributing an unsurpassed capacity for work and strength of will to the masses of Italian emigrants. Angelo Mosso, Vita moderna degli Italiani, (Milan: Treves, 1906).

322 Silvana Patriarca, Italian Vices: Nation and Character from the Risorgimento to the Republic (Cambridge: Cambridge University Press, 2010), 178. 
of the New York Times, wrote that Italians were not like the Americans, nor the English or the Germans, who loved order and regulations. ${ }^{323}$ The Italians, for O'Hare, were naturally lawless people. ${ }^{324}$ According to O'Hare, fascism suited their character and wrote ""Italy is hearing the master's voice." ${ }^{325}$ American nativists, in particular, claimed that fascism was the perfect solution for the deficiencies of Italy's national character, and the best cure for the many problems of its people. Kenneth L. Roberts wrote the profascist tract "Black Magic", which supported this position. ${ }^{326}$

Nationalist narrative failed to define a unified Italian character but strengthened race division. Italian emigrants' race labeled them as Southerners or as Northerners. They did not resent this classification, as they were, themselves, aware of their differences within Italy's borders. In the three periods analyzed in this chapter, we have seen how philosopher Herbert Spencer's (1820-1903) theories on "the survival of the fittest" and the social Darwinist view of society and human development underpinned the policies

\footnotetext{
${ }^{323}$ Anne O'Hare, "Gender and International History: Public and Private in Anne O'Hare McCormick's Journalism," in Public and Private in American History, G. et al. Baritono (Turin: Otto, 2003 [orig 1923].)

${ }^{324}$ Anne O'Hare, "Gender and International History: Public and Private in Anne O'Hare McCormick's Journalism," in Public and Private in American History, G. et al. Baritono (Turin: Otto, 2003 [orig 1923]).

${ }^{325}$ Anne McCormick O'Hare, "Italy is Hearing the Master's Voice," The New York Times Sunday Magazine (1921).

${ }^{326}$ J. P. Diggins, Mussolini and Fascism: The View from America (Princeton: Princeton University Press, 1972); J. P. Cosco, Imagining Italians: The Clash of Romance and Race in American Perception, 1880-1910 (Albany: State University of New York, 2003); Anne O'Hare, "Gender and International History: Public and Private in Anne O'Hare McCormick's Journalism," in Public and Private in American History, G. et al. Baritono (Turin: Otto, 2003 [orig 1923]); E. Ragionieri, L'Italia Giudicata 1861-1945 Ovvero la Storia Degli Italiani Scritta Dagli Altri (Bari: Laterza, 1969).
} 
implemented in the decades between 1870 and 1900, when the Southern Question emerged for the first time. I have utilized two folksongs and folktales as sources to "refer" the peoples' voices and demonstrate how the subalterns expressed awareness of the cultural divide between their geographic worlds. The positivist attention to subalterns of the period 1900-1915 revealed their illiteracy. Raising the literacy level became the prime importance to intellectuals of this period. Between 1861 and 1929, the Italian government passed eight laws to regulate education and to improve literacy. Education went hand in hand discipline, a quality that Italians lacked, according to many scholars of the period. The seed of discipline through education was planted, and from the 1910s to the 1930s, nationalist intellectuals passed from the racist jargon of Northern-Southern, Aryan-Mediterranean/Roman races, to one that used traits of character as taxonomic categories. Italians were either shrewd or foolish, or, in the phase that saw Mussolini's impending alliance with Hitler, bourgeois. Mussolini’s alliance with Hitler in 1938 forced the fascist regime to return to a racial classification of Italians.

This chapter clarifies how the question of race was so easily and continually utilized as a benchmark for Italianità. The ideology of race represented a symbolicsemantic universe of reference points that had been thoroughly used and theatrically enacted by opposite ideologies. Anti-fascists imagined Italians differently from fascists; still they adopted similar standards, i.e. character, region of origin, and education. Once Italians arrived in the United States, their color (white) protected them from a more pervasive and dangerous racism. This un-colored possession, however, did not protect them from the hardships of big cities as New York, and Philadelphia. These difficulties varied according to Italians' "race". Each race had a different expectation. We will read 
in chapter three how Italy's emigrants adjusted to the new environment in these two cities, about their practices, and how they expressed their identity. 


\title{
CHAPTER 3
}

\section{ITALIANS DISCOVER AMERICA AND ITALIANITÀ}

\author{
In fourteen hundred ninety-two, \\ Columbus sailed the ocean blue \\ And found this land, land of the Free, \\ Beloved by you, beloved by me. \\ Winifred Jr. Stoner Sackville ${ }^{327}$
}

Italian racism was born with the forced unification of Italians. In the years of the post-Risorgimento period (1840s-1860s), the Italian Southern question inflamed the national debate in Italy and reached the United States. We have seen in the previous chapter how during the first decades of Italy's unification, Italian positivist scientists Niceforo, Sergi, and Lombroso argued that there were two Italys (North Italy and South Italy) and two races, and that Southern Italians were inferior to their Northern counterparts. ${ }^{328}$ Racism not only marked social relations within Italy, it also affected

\footnotetext{
${ }^{327}$ American poet and educator Winifred Stoner Sackville (1902-83) believed that jingles facilitated the recollection of facts and information. The History of the U.S. is one of her most popular jingles, created with the intent of making the United States history easily recollected by young and adults. These are the first lines of this jingle. I have chosen them to open this chapter because it is significant for this work to note that in 1919 Stoner Sackville wanted the history of the U.S. to start with Christopher Columbus. Many Italian immigrants referred to Cristopher Columbus as the first Italian immigrant to the United States. See Winifred Jr. Stoner Sackville, "The History of the U.S," in Facts in Jingles (1919).

${ }^{328}$ From the table of content of Alfredo Niceforo's Italiani del nord e italiani del sud: Le due Italie (Two Italys); Le due razze (Two Races); Le due psicologie (Two Psychologies); La vita nelle due Italie: alimentazione, la vita intellettuale, la vita morale, la vita economica (Life in the Two Italys: Eating Habits, Intellectual Life, Moral Life, Economic Life; La demografia nelle due Italie (Demography in the Two Italys); La zona barbara (The Barbarian Area). Alfredo Niceforo, L'Italia Barbara e Contemporanea (Milano e Palermo: Remo Sandron Editore, 1898), 611-9.
} 
those who chose to emigrate to the United States. This chapter examines the contradictions of an Italianità imagined, constructed, codified, perceived, and performed from Italy to the United States after the 1860s. It considers the formation of the Italian communities in New York and Philadelphia from the years of the post-unification period to the eve of World War II and compares the construction of these communities to the cultural construction of what it was to be Italian in Miami and adjoining areas in the same period.

Domestic discrimination and economic distress forced a majority of Italian Southerners to leave and some went to New York and Philadelphia, where both Americans and Northern Italians regarded them as outcasts. Here, the Southern immigrants practiced their regional customs within a confined space. The practice of this set of meanings and the boundaries they erected froze their identity, which they did not display as Italian, and delayed their assimilation. Northern and Southern Italian immigrants alike discovered their common Italianità only when some among them decided to enter American politics after years of leadership and guidance of their communities. Immigrants also discovered their Italianità when politicians in Italy presented Italian emigrants as heroes (as remittances started to flow into the semibankrupt Italian economic system, and the Italian expatriates were invested with the responsibility of promoting Italian interests by acting as a lobby.) I argue that the Little Italys of New York and Philadelphia were the outcome of the hostile social environment 
that Southern Italian immigrants found in the English-speaking host societies. Many of the English-speaking residents believed cities belonged to a Northern European stock. ${ }^{329}$ Whereas Northern and a few Southern Italians dribbled into the United States prior to the 1860 s, the sheer volumes of Southern Italians arriving after 1870 alarmed local residents. ${ }^{330}$ Thus, discrimination towards Southern Italians promoted the growth of Italian enclaves within the cities and within these communities, Southern Italians performed their regional identities.

In contrast, the very few Italians who reached Miami and Southeast Florida found a different setting. Here, the majority of the population included immigrants that had arrived around the same period. The English-speaking prominenti (leaders) were themselves newly arrived. Immigrants to this area spoke other languages besides English and practiced religions that were not primarily Protestant as in Northeast America. They had a preconceived idea of Italianità — regardless of any influence the few Italian newcomers to the area might have exerted. This circumstance, along with the fact that there were only a few Italians trickling into the area, explains why Miami and Southeast Florida did not have Little Italys. What is peculiar, however, is that a suggestive cultural construction of Italianità as reflected in art, buildings, and urban planning came to characterize Miami and other areas of Southeast Florida. Evidence of Italianità was

\footnotetext{
329 The inspiring theory is "Nordicism", discussed in the previous chapter.

${ }^{330}$ See my discussion on the Dillingham Commission Report in Chapter 2.
} 
integrated with the growth and expansion of Miami after the 1890s and coincided with the arrival of the small Italian cohort in Southeast Florida.

\section{From a Little Village in Italy to the Little Italys in North America}

We must continue to distinguish between Italian immigrants from North and South Italy because this regional classification influenced the Italian immigrants' patterns of assimilation in the United States and their construction of Italianità. Immigrants from North Italy who migrated to the United States prior to 1860 did not face the racism and the prejudices that characterized the wave of Italian expatriates of the following decades. One of the reasons might also be that concentrations of immigrants from North Italy were hardly found in the United States before $1860 .{ }^{331}$ With few exceptions, those who arrived before the 1860 s were men. ${ }^{332}$ Historian Giovanni Schiavo (1898-1983) wrote that they arrived as explorers, soldiers, political exiles, artists, religious leaders, missionaries, educators, scientists, musicians, gardeners, master craftsmen, and silk workers. Some musicians, music-teachers, and bands of musicians also came from South Italy. ${ }^{333}$ Of the few (4 percent) who migrated to North America, only a small number lived in urban

${ }^{331}$ The destinations of migrants from Italy in the period 1790-1875 were as follows: 4 percent to Asia; 6 percent to Africa; 77 percent to Europe; 4 percent to North America; 7 percent to South America; 1 percent to Australia. Source: Ugo E. Imperatori, Dizionario di Italiani all'estero: Dal XIII secolo sino a oggi (Genoa: L'Emigrante, 1956); Francesco Balletta, Un secolo di emigrazione italiana, 1876-1976, Gianfausto Rosoli (Rome: Centro studi emigrazione, 1978), quoted in Donna Gabaccia, Italy's Many Diasporas (Seattle: University of Washington Press, 2000), 4.

332 Giovanni Ermenegildo Schiavo, The Italians in America Before the Civil War (New York: Italian Historical Society Vigo Press, 1934), 43-5.

${ }^{333}$ Giovanni Ermenegildo Schiavo, The Italians in America Before the Civil War (New York: Italian Historical Society Vigo Press, 1934), 43-5. 
centers before this date. ${ }^{334}$ Apparently, these immigrants shared the American settlers' "Manifest Destiny" belief

in the inevitable fulfillment of the general law which is rolling our population westward, the connection of which with that ratio of growth in population which is destined within a hundred years to swell our numbers to the enormous population of two hundred and fifty millions (if not more), is too evident to leave us in doubt of the manifest design of Providence in regard to the occupation of this continent. ${ }^{335}$

Apparently, these immigrants shared the American settlers' belief in "Manifest Destiny" belief, as American writer John Louis O'Sullivan (1813-1895) suggested in 1845 when he published an essay in which he argued that the United States had a divine mandate to expand throughout North America. In this era, Italian immigrants refused to be confined within the borders of their own communities in the Unites States, rather, they joined the early American pioneers and settlers to move the frontier westward. ${ }^{336}$ But from 1876 to 1914 (the years of mass migration) Italian emigration to the United States took on different qualities. Italian emigration records indicate the change took place probably because "numerically emigration reached enormous proportions. From an average annual emigration of 134,744 persons in the decade 1876-1886, emigration totals jumped to an

${ }^{334}$ United States Census Bureau, a Century of Population Growth, 1790-1900, p. 131.

${ }^{335}$ Manifest Destiny was the nineteenth century American belief that Americans had the mission to progress and modernize the unexplored land of the new American west. See John Sullivan, "Manifest Destiny," The United States Magazine and Democratic Review (1845).

${ }^{336}$ Giovanni Ermenegildo Schiavo, The Italians in America Before the Civil War (New York: Italian Historical Society Vigo Press, 1934), 58. 
average of 269,670 for the years $1867-1900$. These figures were more than doubled by an exodus of 597,246 emigrants per annum in the period of 1901-1909." 337 The new immigrants came mainly from South Italy. As we will see, they arrived as "Southerners" and faced mounting opposition.

Italy's governments tracked the number of its emigrants according to NorthSouth taxonomy, as a 1914 bulletin by the Italy's Department of Labor confirms. ${ }^{338}$ In 1882, the Neapolitan intellectual Pasquale Turiello wrote (using verbs in past tense, which underlines the prolonged existence of the problem) "There were actual causes for an inevitable diversity in Italy. The differences between one region and another were great, but greatest was the difference between the North and the South." 339 Such diversity marked people within Italy as well as the Italian emigrants in their adjustment in the United States. The North-South marker that accompanied Italian emigrants in their transatlantic movements was also used by the United States federal government to classify them upon arrival. ${ }^{340}$

${ }^{337}$ Bollettino dell'Ufficio del Lavoro, Serie Quindicinale. Rome: (July 14, 1914), p. 272. Quoted in Leonard Covello, "The Social Background of the Italo-American School Child: A Study of the Southern Italian Family Mores and Their Effect on the School Situation in Italy and America," ProQuest Dissertations and Theses (1944): 41-2, New York: New York University, 1944. Also see table in Covello, p. 41.

${ }^{338}$ Bollettino dell'Ufficio del Lavoro, Serie Quindicinale. Rome: (July 14, 1914), p. 272. Quoted in Leonard Covello, "The Social Background of the Italo-American School Child: A Study of the Southern Italian Family Mores and Their Effect on the School Situation in Italy and America," ProQuest Dissertations and Theses (1944): 41-3, New York: New York University, 1944.

${ }^{339}$ Pasquale Turiello, Governo e Governati in Italia. Saggio (Bologna: Zanichelli, 1882), 136.

${ }^{340}$ See Chapter 2 for a more extensive discussion of the debate on immigrants' race that erupted in the United States in the first years of the twentieth century. 


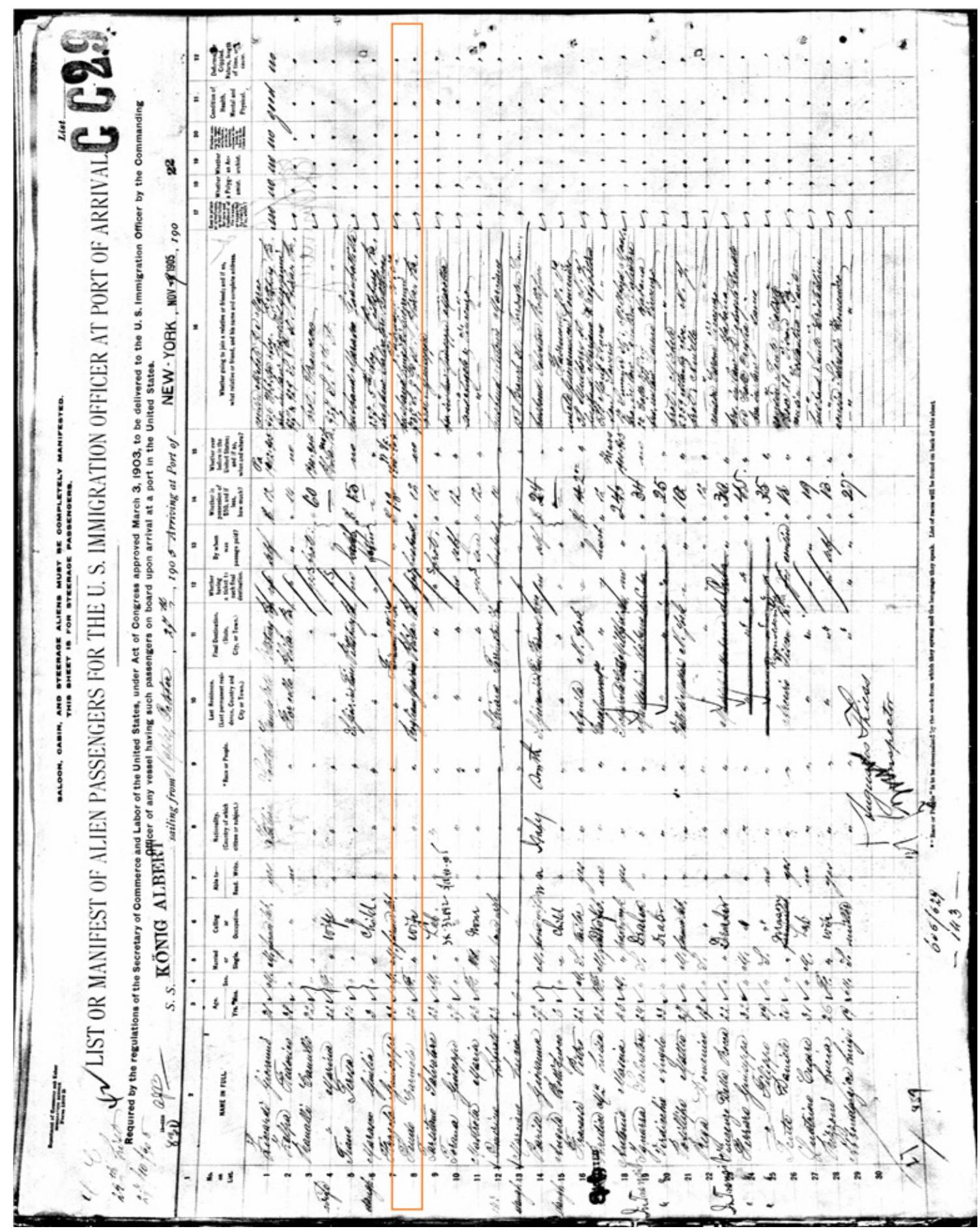

Figure 7. List or Manifest of Alien Passengers for the U.S. Immigration Officer at Port of Arrival, 1905. Source: 1905 ship manifest http://imageshack.us/a/img221/4928/1905e.jpg. http://www.italiangenealogy.com/forum/topic25808.html 


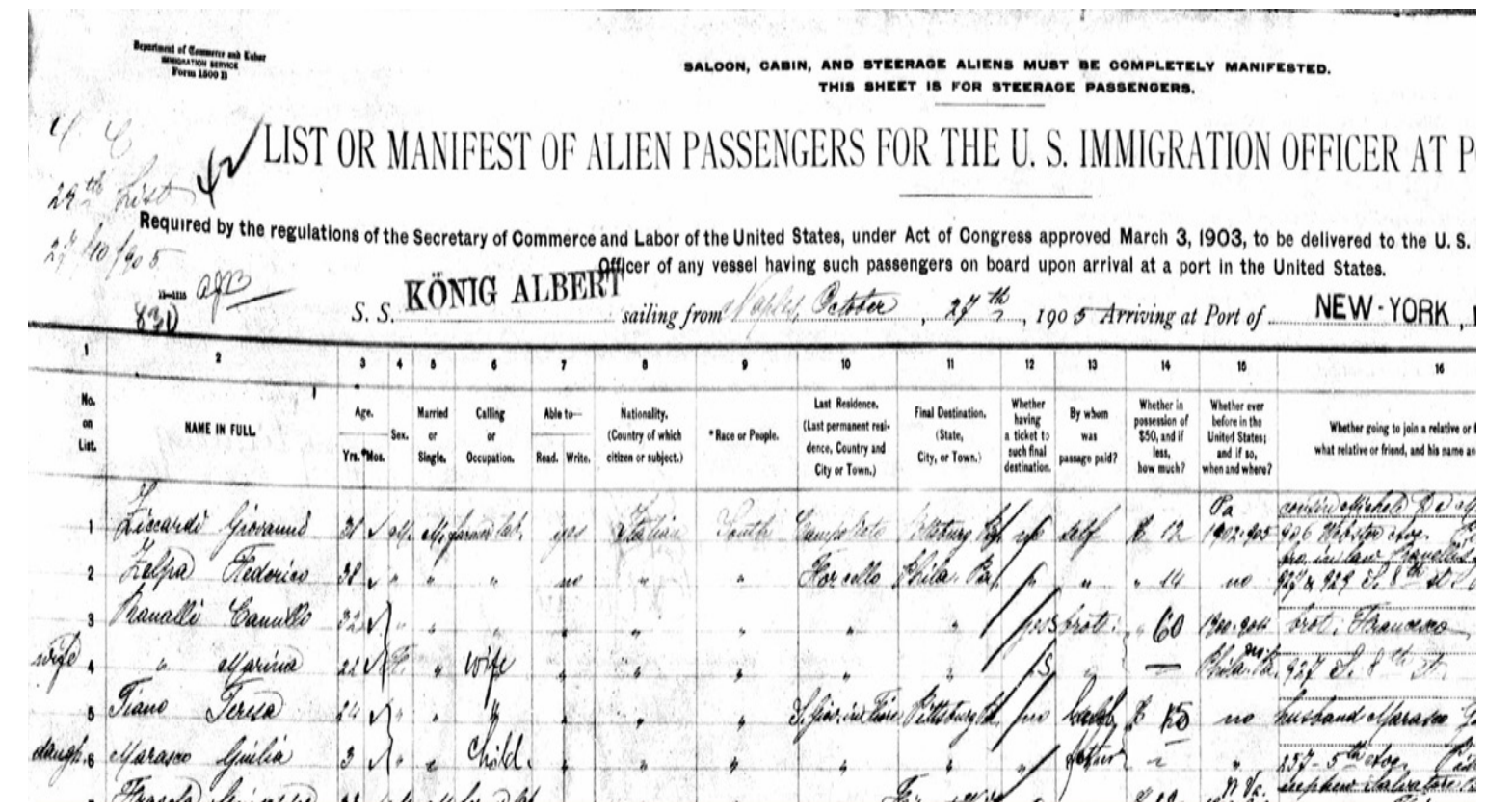

Figure 8. List or Manifest of Alien Passengers for the U.S. Immigration Officer at Port of Arrival (Italy, South). Source: 1905 ship manifest http://imageshack.us/a/img221/4928/1905e.jpg. http://www.italiangenealogy.com/forum/topic25808.html

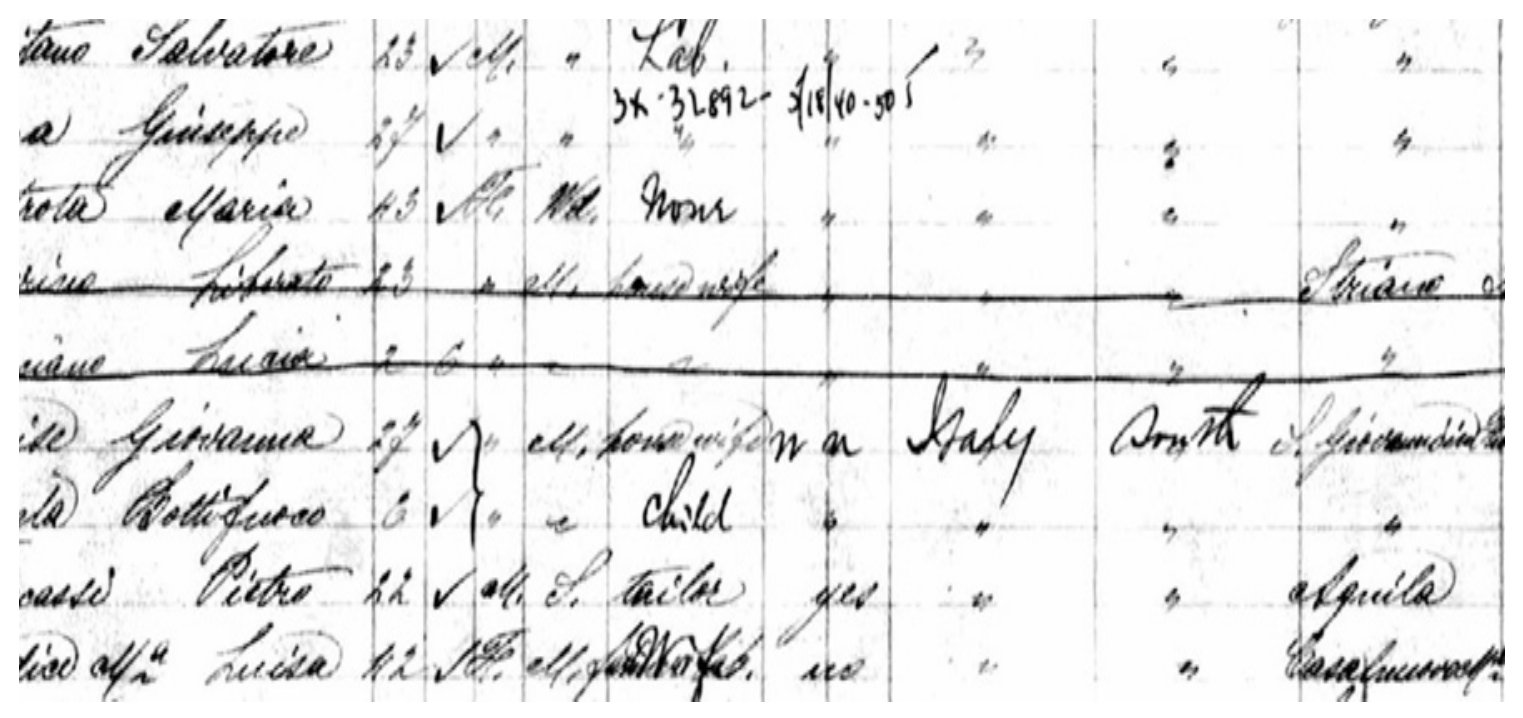

Figure 9. List or Manifest of Alien Passengers for the U.S. Immigration Officer at Port of Arrival (Italy, North). Source: 1905 ship manifest http://imageshack.us/a/img221/4928/1905e.jpg. http://www.italiangenealogy.com/forum/topic25808.html 


\section{TRAPLICATE To be given 6 declarant) \\ UNITED STATES OF AMERICA \\ DECLARATION OF INTENTION \\ Invalid for all purposes soven years after the date hereof!}

No.... 149642 .

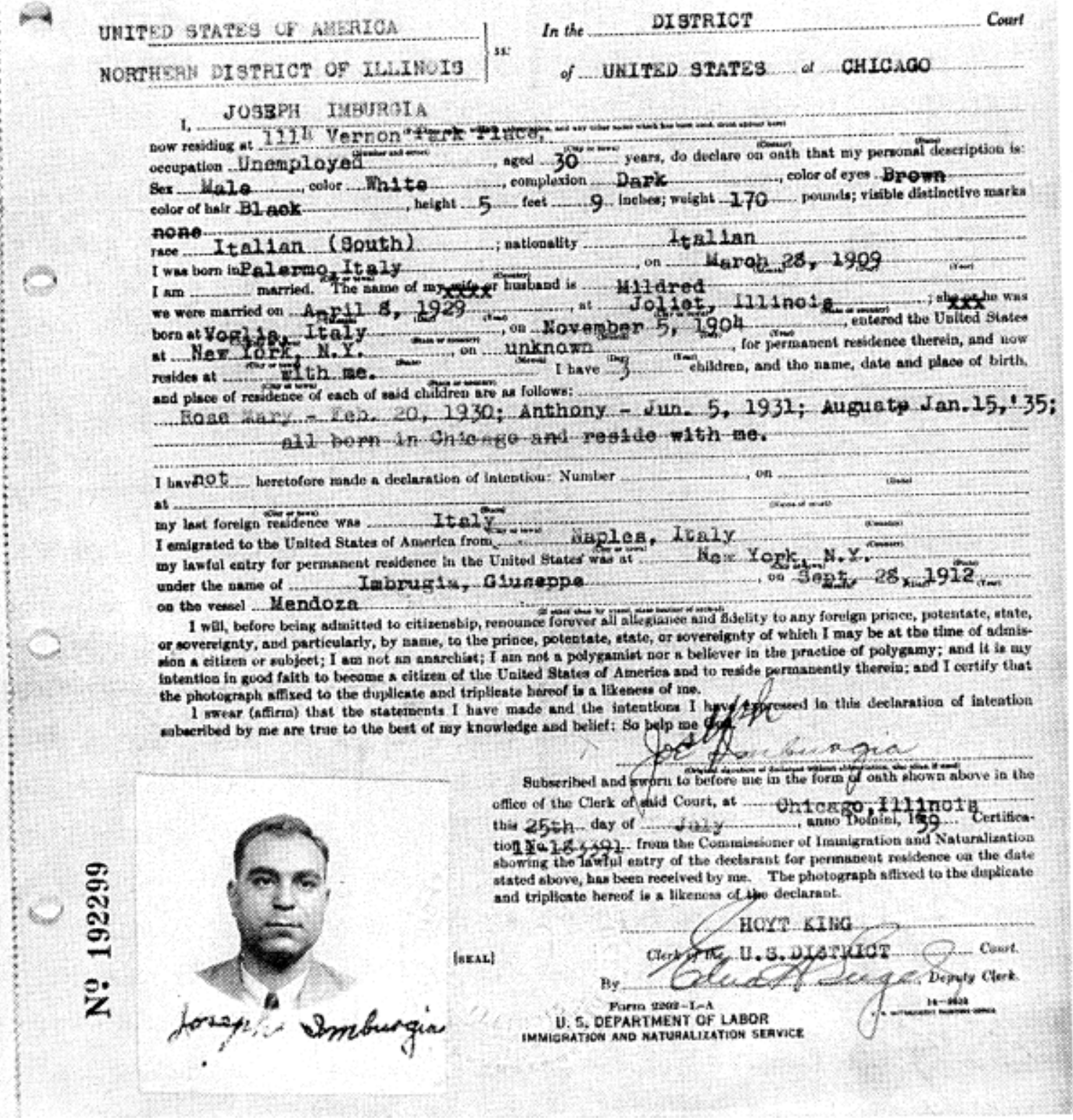

Figure 10. Declaration of Intention, 1939. Source: Thomas A. Guglielmo, White on Arrival: Italians, Race, Color, and Power in Chicago, 1890-1945 Oxford: Oxford University Press, 2003), 8. 
The List or Manifest of Alien Passengers for the U.S. Immigration Officer at Port of Arrival as well as the U.S. naturalization applications throughout much of the early twentieth century required Italians to specify their "race", which, in their case, was North or South Italian. ${ }^{341}$ Even if differences in the outward appearance, behavior, and skills between Italy's Northern and Southern immigrants were invisible, they arrived already "institutionally" marked as "Northerner" or "Southerner." 342 The distinction of "high" Italians and "low" Italians existed in the years that preceded mass migration, when the immigrants from North Italy had established a position from which they could scorn the "low" Italians. ${ }^{343}$ American observers were quick to notice that "they, (the immigrants from North Italy) had established themselves in a position from which they could look down with scorn upon the "low" Italians, could take pains neither to know nor to be classed with them." ${ }^{344}$ Immigrants from North Italy rejected any idea of brotherhood with the people from the South that Italian leaders were fashioning for their nationalistic project. The representation of a common, glorious Italianità as Italian statesmen, poets, and revolutionaries intended it was nowhere to be found among Italians during the first

\footnotetext{
${ }^{341}$ Thomas A. Guglielmo, White on Arrival: Italians, Race, Color, and Power in Chicago, 18901945 Oxford: Oxford University Press, 2003), 9-21.

${ }^{342}$ Thomas A. Guglielmo, White on Arrival: Italians, Race, Color, and Power in Chicago, 18901945 Oxford: Oxford University Press, 2003), 9-21.

${ }^{343}$ Caroline Farrar Ware, Greenwich Village, 1920-1930: A Comment on American Civilization in the Post-War Years (Berkeley: University of California Press, 1935), 152-3.

${ }^{344}$ Caroline Farrar Ware, Greenwich Village, 1920-1930: A Comment on American Civilization in the Post-War Years (Berkeley: University of California Press, 1935), 152-3.
} 
years of immigration to North America. Racial divisions among the people of the Kingdom of Italy actually influenced non-Italian observers in the United States and contributed to the growth of prejudices against them. Americans were "moved to sympathy with the ardor and struggles of spirited patriots" but had "no thought on any particular appeal of Italy", as government officers and authors of "a work in a series reviewing the influx of the various racial strains and nationalities that are making up the composite American" wrote in $1905 .^{345}$ In the Risorgimento years and after the 1860 s, American poets and intellectuals, such as James Russell Lowell (1819-1891), William Lloyd Garrison (1805-79), Henry Wadsworth Longfellow (1807-1882), and Charles Eliot Norton (1827-1908), were interested in Italy's political struggles and supportive of the ideals of liberation and unity, but remained detached from its people. At the turn of the twentieth century, educated Americans had confined their knowledge about Italy and the Italian people to Italy's glorious past, to what writers had documented about the Roman Empire and the Renaissance. ${ }^{346}$ In this vein, their exchanges occurred with the Italian élite, as a 1905 article published in the Cambridge Tribune proves. ${ }^{347}$ American tourists

\footnotetext{
${ }^{345}$ Eliot Lord was Special Agent U.S. Tenth Census: Social Statistics; John D. Trenor (was Chariman of Immigration Committee, National Board of Trade, Annual Session, 1904; Samuel J. Barrows was Secretary of the Prison Association of New York. See Eliot Lord, John D. Trenor, and Samuel J. Barrows, The Italian in America (New York: B. F. Buck \& Co., 1905), 2.

${ }^{346}$ American journalist Margaret Fuller (1810-1850) married an Italian revolutionary, follower of Mazzini, and lived in Italy. Her writings contributed to the growth of sympathy for Italian revolutionary ideas among educated Americans. See Margaret Fuller, These Sad but Glorious Days: Dispatches from Europe, 1846-1850 (New Haven: Yale University Press, 1991).

347 “An Italian decoration bestowed by King Emmanuel on Professor Charles Eliot Norton. The world of letters has been laid under an everlasting obligation by Professor Charles Eliot Norton, of Harvard (now emeritus), in his masterful translations of the poet Dante into English and in his numerous researches as a student of Italian art and history. King Victor Emmanuel II, of Italy, has recognized this fact in the
} 
ignored Italian popular daily life and problems because they were not interested in reality, but in prefabricated memory. ${ }^{348}$ For those who traveled to contemporary Italy, Italian common people remained quaint and picturesque figures acting on a glorious backdrop of ancient ruins. ${ }^{349}$ Clearly, they chose not to spoil the magnificence that they associated with their idea of Italy by connecting this with the image of the people that they met during their visits and whom they would find at home after few years. Those immigrants had little in common with the élite's idealization of the Roman Empire and the Renaissance. The hordes of the newcomers tainted Italian culture as Americans wanted to know it. In 1914, eugenicist and sociologist Edward Alsworth Ross (1866-1951) wrote: "[I]t is important to remember that in race advancement the North Italians differ from the rest of their fellow countrymen," and he lamented that "only a fifth of our Italians are

marked honor just conferred on Professor Norton by creating him a grand officer of the Order of the Crown of Italy; and in thus honoring the distinguished Harvard scholar. King Emmanuel has paid a line compliment to American scholarship, so worthily and notably typified In Professor Norton. This is the highest Italian decoration ever bestowed upon a Harvard graduate. Professor Norton graduated from Harvard in the class of 1846." See "An Italian Decoration," Cambridge Tribune XXVIII, no. 3 (1905, 18 March 1905): 5.

${ }^{348}$ Later works by Romantic British scholars as George Macauley Trevelyan (1876-1962), Bolton King (1860-1937), and Thomas Okey (1852-1935) also excluded the examination of contemporaneous life in Italy. E. C. Vansittart, "Some Italian Invocations," The Antiquarian XXXVIII, no. January-December, 1902 (1902); Ruth M. Underhill, Child Labor in Italy, Report of the Commission for the Tubercolosis, American Red Cross in Italy (Rome: Tipografia Nazionale Bertero, 1919); Grant Showerman, Eternal Rome (New Haven: Yale University Press, 1924); Edgar A. Mowrer, Immortal Italy (New York: Appleton, 1922); Elizabeth Latimer Wormeley, Italy in the Nineteenth Century (Chicago: McClurg and Co., 1903 [3rd ed.]); Tony Cyriax, Among Italian Peasants (London: W.C. Collins Sons and Company, Ltd., 1919); Francis M. Crawford, The Rulers of the South (New York: Macmillan Company, 1900); Colin Reith Coote, Italian Town and Country Life (New York: Brentano, 1925); J. J. Blunt, Vestiges of Ancient Manners and Customs Discoverable in Modern Italy and Sicily (London: John Murray, 1823); Richard Bagot, My Italian Years (London: Mills and Boon Ltd., 1911); Bolton King and Thomas Okey, Italy Today (New York: Charles Scribner's Sons, 1901).

${ }^{349}$ Margaret Fuller, These Sad but Glorious Days: Dispatches from Europe, 1846-1850 (New Haven: Yale University Press, 1991). 
from the North." ${ }^{" 350}$ Ross concluded that the Italian "infusion" in American society was going to fail to "one day make the American stock bloom with poets and painters", because "the figures of Niceforo show that the provinces that contribute most to our immigration [the Southern regions] have been utterly sterile as creators of beauty." ${ }^{351}$ In 1905, American government's officials John J. D. Trenor (1861-1937), Samuel June Barrows (1845-1909), and Eliot Lord gave this account of Italians:

Outside the passing survey of tourists, the Italian common people were practically known to us only by the sight of a rambling organ-grinder or imageseller. This travesty of the wandering minstrel of romance, watching his plaintive monkey, and this peddler of plaster casts on a headboard, were the current expositions of Italy in this country for many years, until the common people began to come over in swarms and enlarge our familiar view of the Italian in America. ${ }^{352}$

The stereotyped images of Italian organ-grinders or religious image-sellers, the most common images showed by American tourists of the Italian lower class, whom they had met in their travels in Italy, clashed with the sight offered by the dramatically increased numbers of the newcomers to the United States after the 1870s. ${ }^{353}$ Similarly, American common people ignored both Italy's celebrated past, the existence of its diverse social

\footnotetext{
${ }^{350}$ Edward Ross Alsworth, The Old World in the New: The Significance of Past and Present Immigration to the American People (New York: The Century Co., 1914), 79-101.

${ }^{351}$ Edward Ross Alsworth, The Old World in the New: The Significance of Past and Present Immigration to the American People (New York: The Century Co., 1914), 79-101.

352 Eliot Lord, John J. D. Trenor, and Samuel June Barrows, The Italian in America (New York: B.F. Buck and Company, 1905), 2.

${ }^{353}$ This class of people was also noticed in New York, in 1860. The U.S. Census counted 1,464 foreign-born Italians living in the city, mainly from the Northern regions of the kingdom. The community looked at them as no more than a "little handful of Italians, mainly a vagabond but harmless class of organ grinders, rag pickers, bear leaders and the like." See Thomas Kessner, The Golden Door: Italian and Jewish Immigrant Mobility, 1880-1915 (New York: Oxford University Press, 1977), 14.
} 
classes and the background stories of the Italian immigrants who had reached the United

States en masse. The sheer numbers of immigrants that arrived in the years 1876-1915 $(4,351,635)$ forced Americans of all social levels to notice

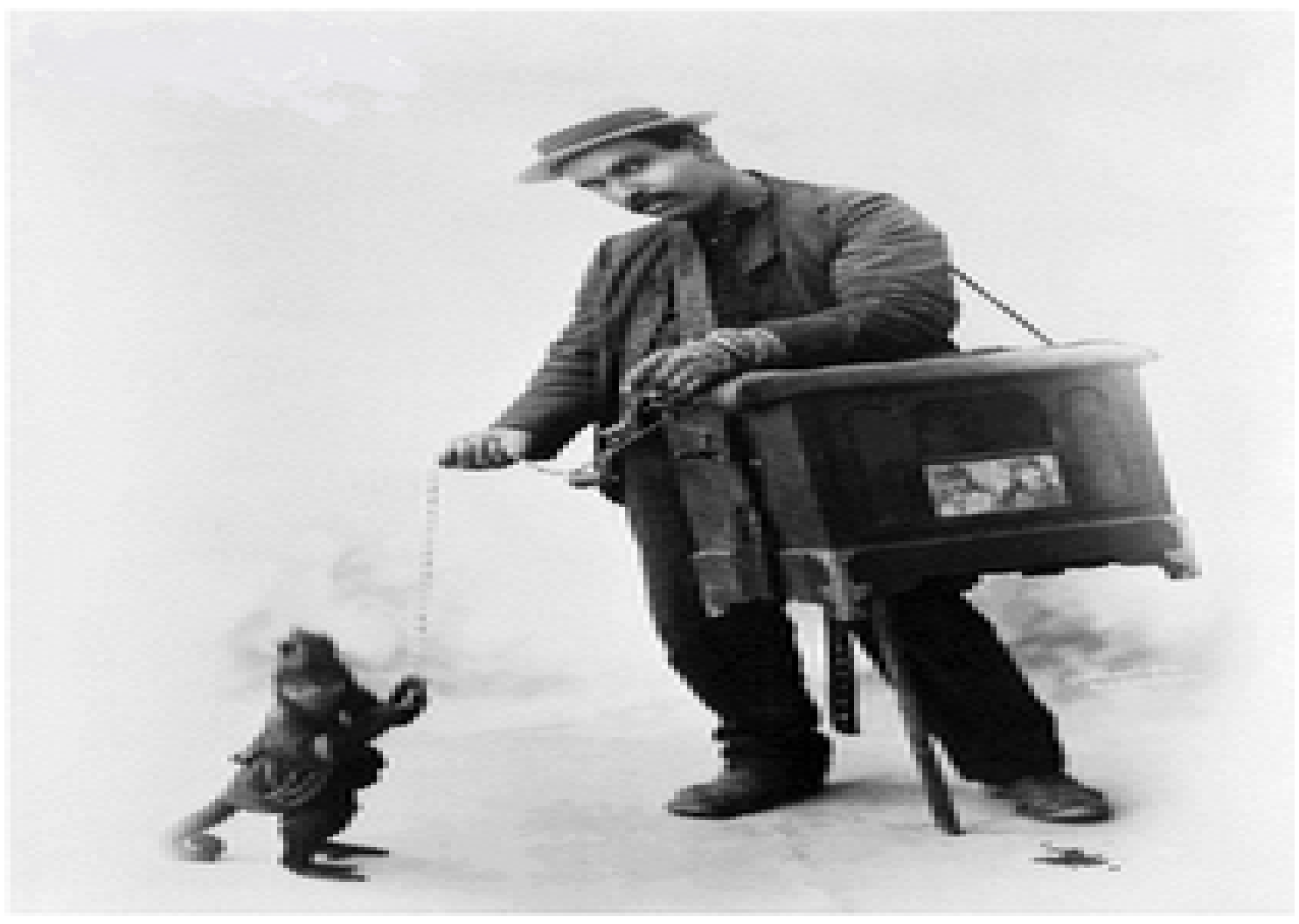

Figure 11. Organ Grinder And Monkey Collect Money. Original caption: Italian organ grinder with his monkey collecting money. Photograph, 1892. Source: Corbis Images, (C) Bettmann/CORBIS.

http://www.corbisimages.com/stock-photo/rights-managed/BE048638/organ-grinder-and-monkey-collect-money

them for the first time. ${ }^{354}$ Soon Americans learned from Northern Italians to discriminate against Italy's Southern immigrants. ${ }^{355}$ The prejudice compounded as a result of the unexpected dramatic circumstances that befell these people in Italy and marked them in

${ }^{354}$ Source: Ugo E. Imperatori, Dizionario di Italiani all'estero: Dal XIII secolo sino a oggi (Genoa: L'Emigrante, 1956); Francesco Balletta, Un secolo di emigrazione italiana, 1876-1976, 


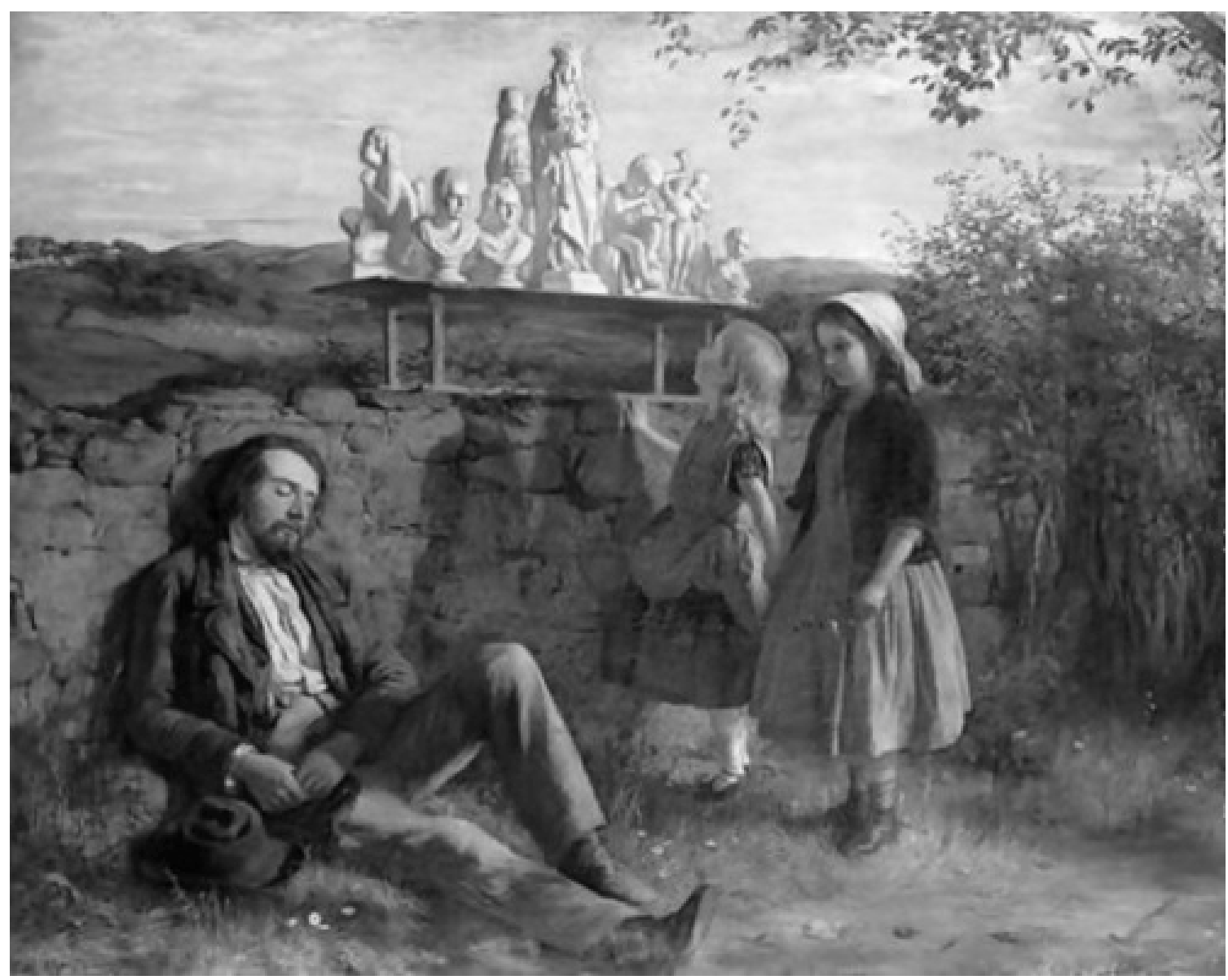

Figure 12. The Italian Image Seller, Hugh Cameron (1835 - 1918). Private Collection/The Bridgeman Art Library. http://www.bridgemanartondemand.com/image.php?imgref=BAL44941

the United States. In 1909, the National Geographic Magazine reported that in the United

States it had become fashionable to assert that "while the Northern Italians might be

desirable, those from the South were not". ${ }^{356}$ The newly arrived Italian Southerners had

Gianfausto Rosoli (Rome: Centro studi emigrazione, 1978), quoted in Donna Gabaccia, Italy's Many

Diasporas (Seattle: University of Washington Press, 2000), 4.

${ }^{355}$ Giuseppe Prezzolini, Come Gli Americani Scoprirono l'Italia, 1750-1850 (Milano: Treves, 1933), 29-35.

${ }^{356}$ Arthur H. Warner, A country where Going to America is an Industry, National Geographic Magazine, Vol. XX (December 1909), p. 1063.Quoted in Leonard Covello, "The Social Background of the Italo-American School Child: A Study of the Southern Italian Family Mores and Their Effect on the School 
no experience of life in urban centers. They came from impoverished agricultural South Italy, where they still practiced a medieval form of farming. They were mostly illiterate and un-skilled. ${ }^{357}$ In contrast to the Italian craftsmen, artists, and intellectuals who had arrived in the United States in an earlier period, many of the new Southern immigrants wanted to earn money and repatriate. This attitude made immigrants returning to South Italy even more undesirable, if possible, by those who believed what also the Italian Prime Minister Francesco Crispi (1819-1901) asserted about repatriation. He stated that Italian citizens returning to Italy brought back incommensurable gains in knowledge, experience, and wisdom. ${ }^{358}$ Most immigrants, however, chose to remain in the United States and settled mainly in the Eastern states.

Southern Italians did not scatter in the vast American land but settled in closelyknit groups in urban cities mainly along the North-Eastern coast of the United States. They became easily recognized by the geographical coordinates within which they chose to live. Consequently, racial stigma marked not only individuals but also blocks and quadrants within major American urban centers. Prejudice affected the assimilation process of the Southern immigrants and favored the preservation of their customs within

\footnotetext{
Situation in Italy and America," ProQuest Dissertations and Theses (1944): 41-2, New York: New York University, 1944.

${ }^{357}$ In 1861, the illiteracy rate was of 78 percent; in 1901, 73 percent; in 1931, it decreased to 21 percent. See Marcello Dei, "La Scuola in Italia," in La Scuola in Italia (Bologna: Il Mulino, 2000).

${ }^{358}$ Quoted in Robert F. Foerster, Italian Emigration of Our Times (Cambridge: Harvard University Press, 1919).
} 
isolated communities, where even regional dialects were retained. ${ }^{359}$ In these isolated communities, immigrants were able to put aside the sense of inferiority and of inadequacy that they experienced when confronting other social groups. Within these communities, immigrants shared emotional responses to discrimination and built a strong communal life. Discrimination and racism, in substance, influenced Italian adjustment and favored the founding of the many Little Italys in the United States.

Little Italys came to exist only in certain areas of the United States and precisely in those populated predominantly by English speakers and where hostility to Catholicism was strongest. ${ }^{360}$ These two elements, and that of race, became the discriminating factors for separating Italian immigrants, and the Southerners among them, from the AngloSaxon and Protestant descendants of the earlier Northern European settlers. Presbyterian minister Lyman Beecher (1775-1863) used sermons to alert Americans to the dangers of Catholicism and immigrants seeking to implant it in the United States "to overturn our republican institutions by immigration and ecclesiastical influence. ${ }^{361}$ Beecher was one of the Know-Nothing Party's ideologues. The Know-Nothingers (as they were called)

\footnotetext{
${ }^{359}$ I use the term "assimilation" to indicate the process of integration of the Italian immigrant group into the social, cultural, political dynamics of the American society.

${ }^{360}$ This statement finds support in Robert Harney's 1985 theory of "Italo-phobia malady" and in Donna Gabaccia's argument that we find Little Italys mainly in English-speaking places. See Donna Gabaccia, "Global Geography of 'Little Italy': Italian Neighborhoods in Comparative Perspective," Modern Italy 11, no. 1 (2006): 9; Robert F. Harney, "Italophobia: English Speaking Malady," Studi Emigrazione 22, no. 77 (1985): 6-43.

${ }^{361}$ Lyman Beecher, A Plea for the West: Six Sermons on Temperance, Sermons on Various Occasions (Cincinnati: Truman \& Smith, 1835), 115.
} 
aimed to save the "country from the degrading influence of Popery." 362 Other immigrant groups also used language and/or race to mark diversity and became targets of discrimination. ${ }^{363}$ The two case-studies of New York and Philadelphia will demonstrate that immigrants from the Kingdom of Italy continued to maintain their regional identities and to live at the margins of the American societies as divided groups of individuals until the first years of the twentieth century.

\section{Mapping the Italian Communities}

The communities that Italians built in the English-speaking, non-Catholic

Northeast from the post-unification years to the eve of World War II were different from the world constructed and inhabited by Italians in the Southeast. Between 1860 and 1880, 68,500 Italians had moved to New York; in 1920, the number of Italians who lived in the city had increased to 391,000. ${ }^{364}$ Historian Howard Marraro (1897-1972) tracked eight Italians already living in Philadelphia in 1790. ${ }^{365}$ The establishment of the first Catholic church in this city (1852), and the founding of the first Italian mutual-aid association

\footnotetext{
${ }^{362}$ Ray Allen Billington, The Protestant Crusade, 1800-1860: A Study of the Origins of American Nativism (Chicago: Quadrangle Books, 1938), 68-90.

363 The German immigrants to Wisconsin, for example, continued to use the German language in their communities until 1889, when the state of Wisconsin issued the Bennet Law to require that all public and parochial Wisconsin schools used the English language exclusively. German immigrants interpreted this judicial act as an attack on their language and culture. See "The Laws of Wisconsin" (Madison, Wisconsin: Democrat Printing Company, State Printers, 1889), chapter 519, Section 5.

${ }^{364}$ Thomas Kessner, The Golden Door: Italian and Jewish Immigrant Mobility, 1880-1915 (New York: Oxford University Press, 1977), 15.

${ }^{365}$ Howard R. Marraro, "Italo-Americans in Pennsylavania in the Eighteenth Century," Pennsylvania History 7, no. 3 (1940): 159-66; Richard N. Juliani, Building Little Italy: Philadelphia's Italians Before Mass Migration (Philadelphia: Penn State Press, 1998).
} 
(1867) meant that the Italian group was powerful, even if not numerous. In fact, less than two thousand Italians lived in Philadelphia until 1892. ${ }^{366}$ Unlike New York, Philadelphia was not an important port of entry for Italian immigrants. The number of immigrants to the city, however, continued to grow as verified by the 1910 U.S. Census report listing 76,734 Italian residents. ${ }^{367}$ Immigrants in both cities needed to adjust to their new lives. They looked for housing and employment and tried to create social networks for protection and support.

The majority of the Italian immigrants came from Italy's rural areas but started their new lives in the center of the major American cities. More than three-quarters of Italians lived in tenement houses in New York. ${ }^{368}$ They could only afford to live in these unhealthy, over-crowded and low-rent accomodations. A 1903 inspection of one of these immigrants' housing facilities revealed that "Many cases have been found where

${ }^{366}$ U.S. Bureau of the Census, Tenth Census of the United States, Statistics of population (Washington: U.S. Government Printing Office, 1882); U.S. Bureau of the Census, Eleventh Census of the United States, Statistics of population (Washington: U.S. Government Printing Office, 1892).

${ }^{367}$ U.S. Bureau of the Census, Thirteenth Census of the United States, Statistics of population (Washington: U.S. Government Printing Office, 1910).

${ }^{368}$ Samuel L. Baily, "The Adjustment of Italian Immigrants in Buenos Aires and New York, 1870-1914," The American Historical Review 88, no. 2 (1983): 290. 
plumbing fixture have been removed and the pipes left open.. ${ }^{369}$ The situation in Philadelphia was not different. ${ }^{370}$ In this city "the only plumbing was a hydrant every



Figure 13. Chart showing the density of the Italian population abroad, according to the December 31, 1881 Italian census. The chart was prepared by Alberto Pisani Dossi, Chief of Cabinet to the Minister of Foreign Affairs Francesco Crispi. Source: Archivio A. Pisani Dossi, b. 5, fasc. 27.

four or five houses which served as the city counterpart of the old village pump. There were no gutters, no sewers; often the yards were flooded with water." ${ }^{371}$.

369 “... The tenants have used the dumbwaiter shaft as a chute for the disposal of rubbish, fecal matter and garbage...".Tenement House Department City of New York, First Report, 1 (New York, 1903), 6-7.

${ }^{370}$ Commissioner of Health, Tenth Annual Report, Commonwealth of Pennsylvania (Harrisburg: J.L.L. Kuhn Printer to the Commonwealth, 1915). 
Neighborhoods came to exist according to regional loyalties both in New York and in Philadelphia. From the 1870s to the 1890s, Italians in New York lived in the 6th and 14th wards of Manhattan, from where they spread out into the areas of Bowery colony and into Harlem. From Manhattan, a modest number of Italians moved to Brooklyn and other boroughs of the city. The situation changed after World War I, when about 50 percent of New York's Italians lived outside of Manhattan. ${ }^{372}$ In the same years, in Philadelphia, Italians lived in the quadrant delimited by Christian, Seventh, Carpenter, and Ninth Streets. As the group grew, new settlements appeared in other areas of North and South Philadelphia. In 1890, the New York's Northern Italians settled along Bleeker Street, while the Genoese populated Baxter Street, near the Five Points. Neapolitans lived in Mulberry Bend and the Sicilians chose Elizabeth Street. In 1920, entire family clans from Cinisi, Sicily, settled between $6^{\text {th }}$ Street and Avenue A, in the Bowery, Harlem, and Brooklyn. ${ }^{373}$ Immigrant Maria T. Fosco remembers that " if a boy from Mulberry Street married a girl from Elizabeth Street—-that was considered a mixed

\footnotetext{
371 “....Some houses had toilets in outdoor shacks, but almost none had baths. Startlingly, however, despite these foul conditions; Miss Dinwiddie reported the Italian bedrooms and living rooms were clean and scrubbed, except those in which men lived without women. The kitchens, however, were not so clean and many Italians, still peasants at heart, kept chickens in their bedrooms and goats in their cellars." In Emily Wayland Dinwiddie, Housing Conditions in Philadelphia (Philadelphia: Committee of the Octavia Hill Association, 1904), 29. See also Joan Younger Dickinson, "Aspects of Italian Immigration to Philadelphia," University of Pennsylvania (1966): 461.

${ }^{372}$ Samuel L. Baily, "The Adjustment of Italian Immigrants in Buenos Aires and New York, 1870-1914," The American Historical Review 88, no. 2 (1983): 291.

${ }^{373}$ Donna Gabaccia, From Sicily to Elizabethan Street: Housing and Social Change Among Italian Immigrants, 1880-1930 (New York: Suny Press, 1984), 65.
} 
marriage." ${ }^{374}$ Italians in Philadelphia followed the same pattern. The village of origin in Italy and dialect determined the location and composition of clusters within the community. Northerners claimed separate spaces from Southerners, and within this group, Abruzzesi, Sicilian, and Calabrian groups further differentiated and showed prejudicial attitudes towards each other. ${ }^{375}$

Economic adjustment was an important indication of Italian attempts to assimilate. The Italian immigrants of an earlier period (post 1860s) had risen from the ranks of unskilled working class to form a strong leadership of contractors, professionals, and entrepreneurs, always within their community. ${ }^{376}$ New York and Philadelphia offered different job outlets. By the turn of the centuries, Italian immigrants made up the great bulk of the working class in New York, while in Philadelphia an Italian-American middle class had already appeared. The fact that Italians represented a small part of New York's population of about one million individuals in 1870, and five million by 1914, is a possible explanation. As such, they could not dominate any sector of the economy. The majority of the Italian individuals living in New York found positions in service and

\footnotetext{
${ }^{374}$ From Vincent Mallozzi's interview of Maria T. Fosco, a member of the Italian American Museum in New York. Vincent M. Mallozzi, "In Little Italy, a Former Bank Will Now Hold Italian Immigrants' Memories,” The New York Times, 2008, 8 September 2008.

${ }^{375}$ Stefano Luconi, From Paesani to White Ethnics: The Italian Experience in Philadelphia (Albany: State University of New York Press, 2001).

${ }^{376}$ Some of these leaders, called prominenti in the Italian community, established a macaroni factory in 1865; secured a mining contract, opened a bank and a steamship agency, worked in the real estate by 1914; became heavy construction contractors in sewerage and subways by 1920s. See Stefano Luconi, From Paesani to White Ethnics: The Italian Experience in Philadelphia (Albany: State University of New York Press, 2001), 18-9.
} 
domestic service (barbers and hairdressers, bootblacks, workers in the manufacturing and mechanical industries, shoemakers and masons.) ${ }^{377}$ There were a few shopkeepers. Only two percent of the Italian population in New York was formed by "white collar" professionals, mainly teachers. ${ }^{378}$ In these four decades New York had become an important industrial center, where the unskilled and semi-skilled work force easily found employment. Upward mobility interested the un-skilled and skilled Italian workers in New York between 1880 and 1905, but in this same period the white-collar workers declined. ${ }^{379}$ Italian immigrants in New York were slow to organize to protect their interests and did not play major roles in the constitution of national labor organizations. ${ }^{380}$ New York's Italians lacked organizational skills and the expectation to advance outside their groups. We have seen how they were predominantly un-skilled or semi-skilled workers, and this probably contributed to their inability to transfer their talents to other environments. In the 1880s, farming skills were of little or no use in urban New York.

Unlike New York, Philadelphia gradually became an industrial center where banking and commercial sectors of the economy had prospered in the 1860s. Here,

\footnotetext{
${ }^{377}$ Samuel L. Baily, "The Adjustment of Italian Immigrants in Buenos Aires and New York, 18701914," The American Historical Review 88, no. 2 (1983): 285.

${ }^{378}$ Samuel L. Baily, "The Adjustment of Italian Immigrants in Buenos Aires and New York, 1870-1914," The American Historical Review 88, no. 2 (1983): 285.

${ }^{379}$ Thomas Kessner, The Golden Door: Italian and Jewish Immigrant Mobility, 1880-1915 (New York: Oxford University Press, 1977), 44-70.

${ }^{380}$ Samuel L. Baily, "The Adjustment of Italian Immigrants in Buenos Aires and New York, 1870-1914," The American Historical Review 88, no. 2 (1983): 287.
} 
between the end of the nineteenth and beginning of the twentieth century, the manufacturing industry developed, offering immigrants opportunities for social mobility. ${ }^{381}$ The data on immigration to Philadelphia show that Northern Italians with a lower middle class background in Italy, who had arrived before the years of mass migration, were able to climb the social ranks to become leaders (or prominenti.) ${ }^{382}$ The few who enjoyed some degree of literacy (who were school teachers in Italy, for example), took university degrees and further advanced in professions. ${ }^{383}$ In 1909 , the Italian diplomat Luigi Aldrovandi Marescotti (1876-1945) reported that professionals in Philadelphia included ten lawyers, sixteen physicians, thirty-one contractors, forty-one bakers and an undisclosed number of steamship agents. ${ }^{384}$ In 1900, Philadelphia’s working class included common laborers (34.8 percent of the city's total number) and

${ }^{381}$ Philip Scranton, "The Transition from Custom to Ready-to-Wear Clothing in Philadelphia, 1890-1930," Textile History 25, no. 2 (1994); Philip Scranton, Endless Novelty: Specialty Production and American Industrialization, 1865-1925 (Princeton: Princeton University Press, 1997); Richard N. Juliani, The Social Organization of Immigration: The Italians in Philadelphia (New York: Arno Press, 1980); Caroline Golab, Immigrant Destinations (Philadelphia: Temple University Press, 1977). The railroad construction provided jobs for a large number of Italians in the 1880s and 1890s.See Charles Snyder, John W. Downie, and Kalp Lois S., Union County, Pennsylvania: A Celebration of History (Montoursville, PA: Union County Historical Society, 2000).

${ }^{382}$ Richard N. Juliani, Building Little Italy: Philadelphia's Italians Before Mass Migration (Philadelphia: Penn State Press, 1998).

${ }^{383}$ Luigi Aldrovandi Marescotti, Note Dell'emigrazione italiana in Pennsylvania, Bollettino dell'emigrazione n. 3 (1911), quoted in Stefano Luconi, From Paesani to White Ethnics: The Italian Experience in Philadelphia (Albany: State University of New York Press, 2001), 19.

${ }^{384}$ Luigi Aldrovandi Marescotti, Note Dell'emigrazione italiana in Pennsylvania, Bollettino dell'emigrazione n. 3 (1911), quoted in Stefano Luconi, From Paesani to White Ethnics: The Italian Experience in Philadelphia (Albany: State University of New York Press, 2001), 19. 
industrial workers (32.6 percent of the city’s total number). ${ }^{385}$ The industries of early twentieth century Philadelphia diversified their production, from textile and clothing to construction and railroads. These areas of production attracted Italian immigrants in the years of mass migration and until World War I. ${ }^{386}$

In the years from 1876 to 1913,61 percent of the new immigrants to the United States left Italy to join their relatives and friends ${ }^{387}$ The majority of Italian emigrant men left their women and young children in Italy. ${ }^{388}$ For this reason they chose to migrate and live in places where acquaintances and relatives already lived. For most of the immigrants at the beginning of mass migration, the journey to the other side of the Atlantic in search of job opportunities was hazardous. Kinsfolk and people from the same villages and cities offered support at the beginning of their venture such as help to secure

${ }^{385}$ Theodore Hershberg et al., "A Tale of Three Cities: Blacks, Immigrants, and Opportunity in Philadelphia, 1850-1880, 1930, 1970," in Philadelphia: Work, Space, Family, and Group Experience in the Nineteenth Century, Essays Toward and Interdisciplinary History of the City, ed. (New York: Oxford University Press, 1981); Stefano Luconi, From Paesani to White Ethnics: The Italian Experience in Philadelphia (Albany: State University of New York Press, 2001).

${ }^{386}$ Philip Scranton, "The Transition from Custom to Ready-to-Wear Clothing in Philadelphia, 1890-1930," Textile History 25, no. 2 (1994); Philip Scranton, Endless Novelty: Specialty Production and American Industrialization, 1865-1925 (Princeton: Princeton University Press, 1997); Richard N. Juliani, The Social Organization of Immigration: The Italians in Philadelphia (New York: Arno Press, 1980); Caroline Golab, Immigrant Destinations (Philadelphia: Temple University Press, 1977).The railroad construction provided jobs for a large number of Italians in the 1880s and 1890s. See Charles Snyder, John W. Downie, and Kalp Lois S., Union County, Pennsylvania: A Celebration of History (Montoursville, PA: Union County Historical Society, 2000).

${ }^{387}$ Enrico Moretti, “Social Networks and Migrations: Italy 1876-1913," International Migration Review 33, no. 127 (1999): 640-57.

${ }^{388}$ Massimo Livi-Bacci, L'Immigrazione e 1'Assimilazione Degli Italiani Negli Stati Uniti (Milan: A. Giuffrè, 1961), 15; Commissariato generale dell'emigrazione, Annuario Statistico Della Emigrazione Italiana Dal 1876 al 1925 (Rome: Edizioni del Commissariato generale dell'emigrazione, 1926). 
housing and to find jobs. ${ }^{389}$ Data indicate that in the years $1890-1910$, approximately 77 percent of the Italian immigrants to the United States were males, and nearly 80 percent of these were between 14 and 44 years of age. ${ }^{390}$ One explanation for the gender-specific Italian immigration pattern could be that immigrants to the United States expected to return to Italy after raising sufficient funds. Many, however, chose to remain in the new country. Once established, they rented what they could afford, in the same neighborhood where they had arrived and found support. Italians wrote letters to their relatives describing the better circumstances and the opportunities to be found in the new country. Many followed thereafter. Very few, like Emilio Lorenzon, a literate peasant, chose to remain in Italy when his eldest brother Charles (Carlo) left in 1896. Soon after Charles left Italy, another brother, Gus (Agostino) followed. Between 1896 and 1902, one after the other, all the Lorenzon brothers had left their village in Friuli in Italy and migrated to the United States. Emilio enlisted as a soldier in the Italian army, stationed in Padua, and exemplifies how those who rejected emigration were saddened. ${ }^{391}$ On March 26, 1904, he wrote a letter to his brothers, recent immigrants to the United States: "How sad are our parents now that they are old at seeing us leaving one by one! But we have to accept our fate. We were not given the privilege of staying together. I hope someday

\footnotetext{
${ }^{389}$ Gladys Palmer, Survey for the Works Progress Administration Operative Plasterers' and Cement Masons' International Union, Local \# 8, Papers (1936).

${ }^{390}$ Massimo Livi-Bacci, L'Immigrazione e l'Assimilazione Degli Italiani Negli Stati Uniti (Milan: A. Giuffrè, 1961), 15; Commissariato generale dell'emigrazione, Annuario Statistico Della Emigrazione Italiana Dal 1876 al 1925 (Rome: Edizioni del Commissariato generale dell'emigrazione, 1926).

${ }^{391}$ Joan Savarino, "Memories in Artifact and Stone: Italians Build a Neighborhood," Germantown Crier 53 (2003): 48-64.
} 
we'll be all together again." Charles, Gus, and Victor (Vittorio) Lorenzon, lived in the same neighborhood in Philadelphia. They spoke the same dialect, shared the same beliefs, professed the same religion, and helped each other to find housing, jobs, and comfort. In 1926 the Lorenzons built their own home in Chestnut Street. Historian Joan Savarino offeres a detailed description of the Lorenzon brothers' house, illustrating how

Its design, a classic center hall colonial, is in keeping with contemporary American tastes of the period, but if closely surveyed, certain features indicate the skills and values of Italian craftsmanship. [...] The roof is typical of the landscape of the Italian folk past. The cut stone quoining and cut stone windows and door surrounds are a testament to the workers' fine skills. The gargoyle on the front portico, the arches on the sun porch, are elements that reflect the owner's aesthetic." 392

The Lorenzons, and many like them, recreated a memory of their village in North America and here they continued to perform their identity as Lorenzon brothers, the American branch of a Friulan family. Conversely, the Italians present in Miami and Southeast Florida contributed their labor and craftsmanship to build structures, artworks, and homes to reenact aspects of Italian culture the way Anglo wealthy patrons imagined them. They discovered and put their identity at the service of a representation 'à la italiana' of Italianità.

Italian immigrants in New York and Philadelphia also rejected the idea of a common ancestry from the early immigration period to the first decades of the twentieth

\footnotetext{
${ }^{392}$ Joan Saverino, "Mapping Memories in Stone," in Global Philadelphia: Immigrant Communities Old and New, Ayumi and Osirim Takenaka, Mary Johnson (Philadelphia: Temple University Press, 2010), 67-8.
} 
century (1830s-1930s). ${ }^{393}$ Some Italian revolutionaries left Italy and established lives in New York, Boston, and Philadelphia. Such was the case of Piero Maroncelli (17951846), who reached New York in 1833, where he lived in poverty as Italian tutor until he died. ${ }^{394} \mathrm{He}$ and other lesser-known Italian revolutionaries and idealists, after being forced into exile, also faced defeat in spreading their ideals of a unified Italy among the Italians in the United States. ${ }^{395}$ Immigrants continued to reconstruct their native villages in the American urban centers. They established "Little Avigliano" in East Harlem, "Little Cinisi" in Manhattan, and "Little Calabria" on Mulberry Street in New York City. In Philadelphia, immigrants arriving from Spezzano Albanese, in the Calabria region, clustered in Montrose Street. ${ }^{396}$ The Italian communities in New York and Philadelphia were divided in sub-communities that represented most of Italy's regions. ${ }^{397}$ When Italians were recruited by a "padrone" (master), they still maintained homogeneity when

\footnotetext{
${ }^{393}$ Angeline H. Lograsso, "Piero Maroncelli in Philadelphia," Romanic Review 24, no. 4 (1933): 323-9; Giovanni Ermenegildo Schiavo, The Italians in America Before the Civil War (New York: Italian Historical Society Vigo Press, 1934); Richard N. Juliani, Building Little Italy: Philadelphia's Italians Before Mass Migration (Philadelphia: Penn State Press, 1998).

${ }^{394}$ Similar to Maroncelli's is also the case of the cobbler Frank Spiziri (1878-1958), a fervent Italian nationalist who lived in Philadelphia. See Stefano Luconi, From Paesani to White Ethnics: The Italian Experience in Philadelphia (Albany: State University of New York Press, 2001), 23; Angeline H. Lograsso, "Piero Maroncelli in Philadelphia," Romanic Review 24, no. 4 (1933): 323-9.

${ }^{395}$ Stefano Luconi, From Paesani to White Ethnics: The Italian Experience in Philadelphia (Albany: State University of New York Press, 2001), 23; Angeline H. Lograsso, "Piero Maroncelli in Philadelphia," Romanic Review 24, no. 4 (1933); Stefano Luconi, "The Changing Meaning of Ethnic Identity Among Italian Americans in Philadelphia During the Inter-War Years," Pennsylvania History 63, no. 4 (1996): 562.

${ }^{396}$ Stefano Luconi, From Paesani to White Ethnics: The Italian Experience in Philadelphia (Albany: State University of New York Press, 2001), 27.

${ }^{397}$ Robert A. Orsi, The Madonna of 115th Street: Faith and Community in Italian Harlem, 18801950 (New Haven: Yale University Press, 2010).
} 
they clustered in a new country. ${ }^{398}$ In Philadelphia, of the 17,388 Italians who arrived from 1900 and 1919, 10,321 came from the Abruzzi. ${ }^{399}$ The streets of lower Manhattan in New York were divided into distinct communities which retained the original characteristics of the villages of origin. Scholar Thomas Kessner quipped they were like "the pungent cheeses which the Italians brought with them." ${ }^{400}$ Once established, like the Lorenzon brothers, they wrote letters and encouraged their women and their kin to join them in the new foreign country. Thus a new cycle began. The settlements grew and the tenements' overcrowding too.

\section{From Italian Regional Affiliation to Italian National Loyalty}

Urban American streets became the Italian immigrants' way to escape overcrowding. ${ }^{401}$ In New York and in Philadelphia men and children met at street corners, but paid careful attention not to cross sub-settlements' boundaries. ${ }^{402}$ Socialization and business were conducted in the dialects spoken by the groups'

${ }^{398}$ For Donna Gabaccia, padroni were middlemen who sometimes financed trips of labor migrants across the seas. They were "[...] labor agents who exacted a commission from their clients. They sold jobs to men eager to migrate. [...]”. Donna Gabaccia, Italy’s Many Diasporas (Seattle: University of Washington Press, 2000) 64-5.

${ }^{399}$ Stefano Luconi, From Paesani to White Ethnics: The Italian Experience in Philadelphia (Albany: State University of New York Press, 2001), 26.

${ }^{400}$ Thomas Kessner, The Golden Door: Italian and Jewish Immigrant Mobility, 1880-1915 (New York: Oxford University Press, 1977), 16.

${ }^{401}$ Richard N. Juliani, The Social Organization of Immigration: The Italians in Philadelphia (New York: Arno Press, 1980); Donna Gabaccia, From Sicily to Elizabeth Street: Housing and Social Change Among Italian Immigrants, 1880-1930 (Albany: State University of New York Press, 1984).

${ }^{402}$ Richard N. Juliani, The Social Organization of Immigration: The Italians in Philadelphia (New York: Arno Press, 1980); Donna Gabaccia, From Sicily to Elizabeth Street: Housing and Social Change Among Italian Immigrants, 1880-1930 (Albany: State University of New York Press, 1984). 
components. Villages' customs were re-enacted and respected. Italians put a lot of effort in finding the ingredients for their own traditional food. In some cases, this became the stimulus to start small businesses and perhaps one of the block's regional stores. ${ }^{403}$ When the community needed professionals (doctors, lawyers, or pharmacists), members preferred to consult those who had the same places of origin. ${ }^{404}$ At the beginning of the twentieth century, Banca dell'Aquila, Banca di Torino, Banca di Napoli, Banca di Basilicata and Calabria opened offices in New York and Philadelphia. There was almost a bank for each diverse Italian regional loyalty. ${ }^{405}$ Sub-national divisions also controlled admission to mutual aid societies, recreational clubs, and churches. Between 1900 and 1914, a great number of such institutions were established in New York. ${ }^{406}$ Only in 1905 was the Order of the Sons of Italy born as a confederation of the many regional societies established in the major American cities, but its debut was not successful. It took another decade before divisiveness within the immigrants' institutions was overcome. These institutions played an important role in Italian immigrants' settlement in the new

${ }^{403}$ For example, a macaroni factory called "La Fara." Stefano Luconi, From Paesani to White Ethnics: The Italian Experience in Philadelphia (Albany: State University of New York Press, 2001).

${ }^{404}$ Stefano Luconi, From Paesani to White Ethnics: The Italian Experience in Philadelphia (Albany: State University of New York Press, 2001).

${ }^{405}$ Mark I. Choate, Emigrant Nation: The Making of Italy Abroad (Cambridge and London: Harvard University Press, 2008), 72-100; Stefano Luconi, From Paesani to White Ethnics: The Italian Experience in Philadelphia (Albany: State University of New York Press, 2001).

${ }^{406}$ In 1910, New York counted two thousand societies, with forty thousand members out of an Italian population of 340,000. See Samuel L. Baily, "The Adjustment of Italian Immigrants in Buenos Aires and New York, 1870-1914," The American Historical Review 88, no. 2 (1983): 293. 
country. ${ }^{407}$ Membership in such societies was almost exclusively drawn from the workforce, but as the Italian immigrants needed leadership and guidance, Italian businessmen or other successful Italian immigrants became their officers. ${ }^{408}$ Immigrants joined mainly mutual aid societies because they provided the services needed in the direst circumstances: sickness, death, unemployment. Immigration scholars argued that boarding houses and saloons were the first hubs of the Italian immigrant communities, and taverns were the social center for working-class males. ${ }^{409}$ Newspapers were also important sources to find jobs and advice on how to settle in the community.

Newspapers became an important tool of propaganda within the immigrant community and contributed to construct Italianità. They did not require subscriptions and membership, but were also an important reference for those who were not members of mutual aid societies. Newspapers published job postings, articles on how to survive in America, cultural notes (such as advertisements for groceries, importers of oil, doctors, lawyers, of religious parades and celebrations), and reports of the latest news on Italy's

${ }^{407}$ George E. Pozzetta, The Italians of New York City, 1890-1914 (Chapel Hill: University of North Carolina, 1971); Emilio Zuccarini, Il lavoro degli Italiani nella repubblica argentina, Dal 1516 al 1910: Studi, Leggende e Ricerche (La Patria degli Italiani, 1910).

${ }^{408}$ Pozzetta referred the case of Louis V. Fugazy (1839-1930), originally Luigi V. Fugazzi), labor agent and banker, who promoted the establishment in New York of a hundred societies and became president of fifty. See George E. Pozzetta, The Italians of New York City, 1890-1914 (Chapel Hill: University of North Carolina, 1971).

${ }^{409}$ John W. Briggs, An Italian Passage: Immigrants to Three American Cities, 1890-1930 (New Haven \& London: Yale University Press, 1978), 141; Gary Ross Mormino, Immigrants on the Hill: Italian Americans in St. Louis, 1882-1982 (Urbana: University of Illinois, 1986). 
affairs. ${ }^{410}$ For this role, the communities' leaders desired to control newspapers. ${ }^{411}$ In New York, in 1859, ' 'Eco d'Italia was the first daily Italian publication, followed by $L a$ Voce del popolo, of 1869, and Il Progresso Italo-americano, in $1880 .^{412}$ The Progresso Italo-americano's founder, Carlo Barsotti (1850-1927), a successful businessman, had difficulty in finding journalists who could read and write Italian correctly, but this setback did not halt his plans. ${ }^{413}$ Journalism for Barsotti was an exercise in adapting and translating American news, Italian clippings, advertisements and commentaries on the life in the Italian communities in New York (written in not always perfect Italian.) The first edition had four pages, two of which reported on Italy's current events, while the other two were devoted to advertisements. ${ }^{414}$ Through his newspapers, Barsotti raised funds to build monuments to prominent Italians. Busts and statues to Giuseppe Garibaldi, Giovanni Da Verrazzano, Giuseppe Verdi, and Christopher Columbus were disseminated

${ }^{410}$ Robert E. Park, The Immigrant Press and Its Control (New York and London: Harper and Brothers Publishers, 1922).

411 They still do. A recent study shows that in the United States in 1979, 24 Italian periodicals were published in the East Coast (of these, 5 in Italian, 13 in Italian and English, and 6 in English); 12 periodicals were published in the North Central area (1 in Italian, 7 in mixed languages, 4 in English); 2 periodicals were published in the South ( 1 in Italian and English and 1 in English); 7 periodicals were published in the West Coast (3 in Italian, 2 in Italian and English, 2 in English.). See Hermann Haller, "Linguistic Interference in the Language of 'Il Progresso Italo-Americano'," Italian Americana 5, no. 1 (1979): 58.

${ }^{412}$ Hermann Haller, "Linguistic Interference in the Language of 'Il Progresso Italo-Americano'," Italian Americana 5, no. 1 (1979): 58.

${ }^{413}$ Robert E. Park, The Immigrant Press and Its Control (New York and London: Harper and Brothers Publishers, 1922), 344.

${ }^{414}$ Robert E. Park, The Immigrant Press and Its Control (New York and London: Harper and Brothers Publishers, 1922), 344. 




Figure 14. "Le Tragedie del Lavoro.” Source: Il Progresso Italo-Americano. March 28, 1911 (News MF 2297). Serial and Government Publications Division. http://memory.loc.gov/ammem/awhhtml/awas12/d01.html. ${ }^{415}$

${ }^{415}$ The text reads: "On March 25, 1911, a fire swept through the Triangle Shirtwaist Company, an anti-union shop in Greenwich Village. One hundred and forty-six employees lost their lives in one of the worst industrial disasters in the history of New York City. Most of these workers were recent Jewish female immigrants; others were young Italian immigrant women. The huge public outcry and wave of sympathy for working women led to the eventual establishment of a Factory Investigating Commission, which was instrumental in drafting new factory legislation that mandated improved working and safety conditions. A list of the names of the Italian women who had been identified as victims of the fire appears on the front page of the Italian-language New York City daily Il Progresso Italo-Americano, next to the sketch of a victim." 
in New York, to symbolize what it meant to be Italian to this successful immigrant and to his readership. ${ }^{416}$ Through his paper, Barsotti created his idea of Italianità. Also if Il Progresso was the main daily publication, it had several competitors. As their names suggest, each took a different ideological stance: L'Operaia (1913-9) (the worker), Il Proletario (1899-1946) (the proletarian), La Questione Sociale (1895-1916) (the social question.) In Philadelphia, the first newspapers aimed to maintain the bond that immigrants had with their places of origin in Italy. "Il Vesuvio", for example, founded in 1882, took the name from the volcano in the Italian region of Campania. Barsotti sowed seeds of Italianità that others reinforced.

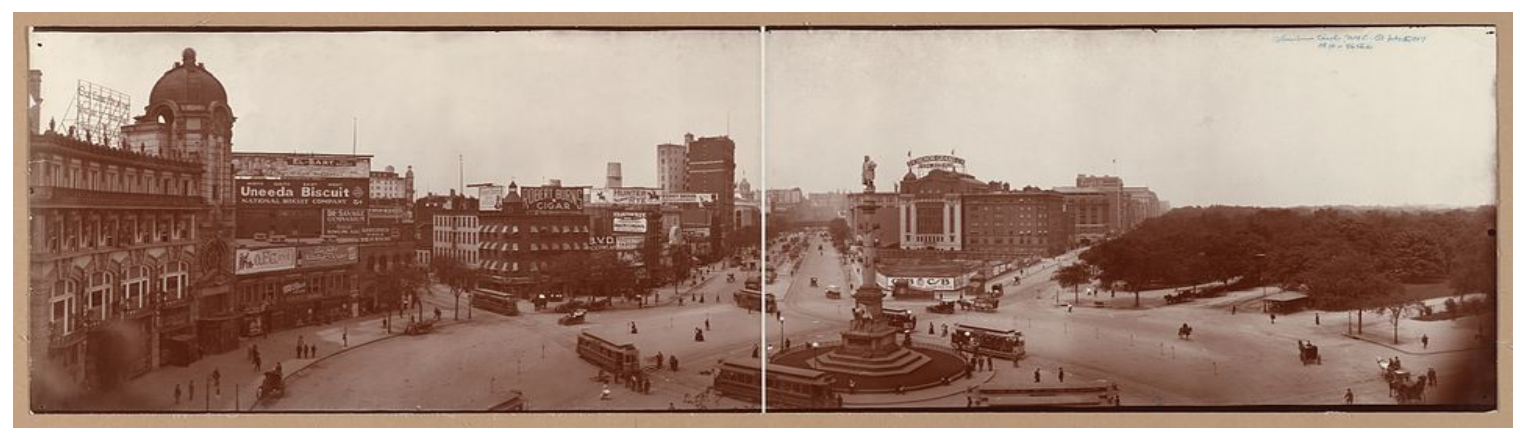

Figure 15. Columbus Circle, New York. Photograph, c. 1907. Source: Library of Congress Prints and Photographs Division Washington, D.C. 20540 USA http://hdl.loc.gov/loc.pnp/pp.print.

At the dawn of the twentieth century, some of these publications contributed to overcome regional disagreements to expand their readership. By doing so, they injected the seed of national consciousness within the communities' rigid boundaries. In Philadelphia, Giuseppe (1874-1927) and Giovanni Di Silvestro (1879-1958) founded La

\footnotetext{
${ }^{416}$ Gertrude R. Brigham, “The New Memorial to Dante in Washington,” Art \& Archaeology, Archaeological Institute of America 13 (1922): 32-5.
} 
Voce del Popolo and Charles C.A. Baldi (1877-) founded L'Opinione. These were not idealistic moves. Both leaders had ambitions that went beyond Little Italy's borders. The Italian immigrants' leaders felt that they were ready to complete their assimilation and wished to be part of the host society's political establishment. At the verge of successful careers as businessmen and entrepreneurs within their regional boundaries, leaders from Philadelphia and from New York were ready to climb the American social ladder. In New York and Philadelphia, these men believed that as representatives not of regional and divided enclaves but of the Italian immigrants they could claim a role as mediators between mainstream America and the Italian groups. They needed endorsement from a large base - the immigrant communities. Such an elevation, however, had to make them representatives not merely of Italy's regional interests, but also of American nationalistic claims. The 1906 Congressional discussion of a literacy test to restrict immigration to the United States provided one of these opportunities. ${ }^{417}$

The general public generally perceived the first Italian immigrant to America as explorer Christopher Columbus (1451-1506). He therefore became a fitting symbol of immigrants' right to acceptance by the host society. ${ }^{418}$ The élites in the Italian American

\footnotetext{
417 "In 1906 Congress began discussing the introduction of a literacy test provision to restrict immigration to the United States by excluding newcomers who could not read and write in their native languages. 64\% of Italian immigrants in the US were illiterate. The US passed the Literacy Act in 1917." In Luigi Di Comite, "Aspects of Italian Emigration, 1881-1915," in Migration Across Time and Nations, Ira Glazier and Luigi De Rosa (New York: Holmes and Meier, 1986), 35.

${ }^{418}$ Charles Speroni, “The Development of the Columbus Day Pageant of San Francisco," Western Folklore 7, no. 4 (1948): 325-35.
} 


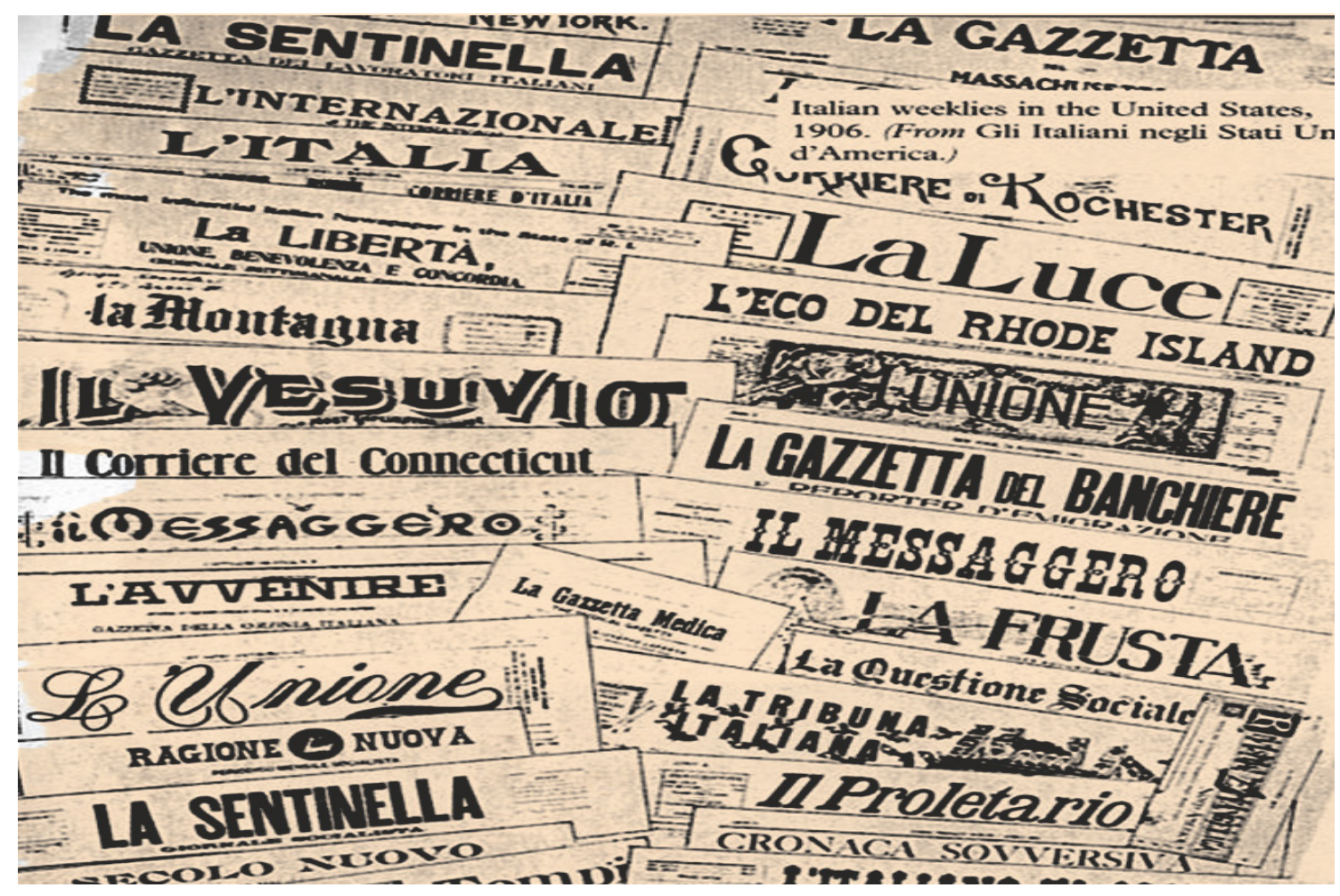

Figure 16. This photo shows that there was a newspaper almost for each community or ideological group.

communities and the Catholic Church joined efforts to promote celebrations of the navigator who was not portrayed as Genoese, but as Italian. The ideas of a common ancestry and of a national identity entered the immigrants' discourses. Italian American lobbies worked to establish Christopher Columbus festivities in major American cities. In April 1934, Columbus Day became a federal holiday. ${ }^{419}$ From 1905 to 1928 Italy was hit

${ }^{419}$ Franklin Delano Roosevelt (1882-1945) was president. Sale Kirkpatrick, Christopher Columbus and the Conquest of Paradise (London: Tauris Parke Paperbacks, 2006), 359; United States House of Representatives (30 April 1934). "36 USC 105, ch. 184, 48 Stat. 657”. United States Code. Office of the Law Revision Counsel. 
by natural disasters such as earthquakes, volcanic eruptions, and floods. ${ }^{420}$ These dramatic events provided the immigrant élite with the occasion to claim their belonging to Italy and to rush to the rescue of their fellow nationals. ${ }^{421}$

Editors were also united in their efforts to provide for Italian relief. In January 1909 a procession of four carriages decorated with Italian and American flags and trucks provided by an Italian Express Company traversed the many subdivisions of New York's Little Italy. The carriages and trucks carried boxes for money donations, medicines, clothing and other supplies to help people in Sicily and Calabria who had been hit by an earthquake and tsunami on December 28, 1908. Pretty Italian girls sat in the carriages. The drive was promoted by Barsotti, editor of Il Progresso, which had reported for months on the earthquake disaster and fundraising efforts (accompanied by the names of donors even for as little as ten cents). ${ }^{422}$ Similarly, Philadelphia's leaders asked the members of all the Italian community for help. They had done the same few years before, in 1906, when people in Campania and Calabria had suffered the disastrous consequences

\footnotetext{
${ }^{420}$ Earthquakes in Nicastro, Calabria, 09/08/1905; Reggio Calabria and Messina, 12/28/1908; Avezzano, 01/13/1915; Carnia, 1928. Flooding in North Italy, 1905. Vesuvio eruption, 04/04/108; Etna eruption, 1923.

${ }^{421}$ Salvatore J. LaGumina, "Italian Americans Respond to the Messina Earthquake Disaster," in Italian Americans: Bridges to Italy, Bonds to America, ed.s Luciano J. Iorizzo and Ernest Rossi, E. (New York: Teneo Press, 2010), 65-83.

${ }^{422}$ Salvatore J. LaGumina, "Italian Americans Respond to the Messina Earthquake Disaster," in Italian Americans: Bridges to Italy, Bonds to America, ed.s Luciano J. Iorizzo and Ernest Rossi, E. (New York: Teneo Press, 2010), 78.
} 
of Vesuvio's eruption in the bay of Naples, and an earthquake in Calabria. Di Silvestro had written in Il Popolo "We are all brothers." 423

The Italian immigrants' leaders in New York and Philadelphia understood that sub-national divisiveness was counterproductive. They wished to advance vertically in society. They could pursue this ambition by becoming intermediaries between the host society and the immigrant national community. World War I provided the opportunity to Italians and Italian Americans to imagine themselves as brothers of the same motherland. News of Italy's entry into the war in 1915 was welcomed by many in the Italian community in New York and Philadelphia. In 1917, the United States' declaration of war against the German and the Austria-Hungary Empires offered Italian immigrants a redemptive opportunity from their status as outsiders. Fighting together against a common enemy served to unite Italians under a common ancestry, and helped their assimilation in the United States. Through the Italian institutions, mutual aid societies, and newspapers, the Little Italys' élite chose undisputed symbols of Italianità to rally Italian immigrants around core concepts.

World War I served the Italian nationalistic agenda by encouraging cohesion between the sub-national interests and further developed the idea of a common ethnic identity. The discovery of an ethnicity that was not based on color or race helped Italian groups to advance within the North American society. Unfortunately, this enthusiasm

\footnotetext{
423 "Siamo tutti Italiani", quoted in Stefano Luconi, From Paesani to White Ethnics: The Italian Experience in Philadelphia (Albany: State University of New York Press, 2001), 36.
} 
eventually became a new threat to Americanism. The post-war years brought a new wave of nativism, new restrictions on immigration, and discrimination against Italians. Once again Italians and Italian Americans in the United States experienced 'otherness'. Within their neighborhoods, some searched for beliefs and cultural signs with which they could identify and recognize as familiar and therefore proved comforting. Mussolini provided symbols of an Italianità that was presented as strong and glorious. Fascist colonial enterprises, even the 1938 Fascist Racial Laws (based on color and on religion, not on a north- south- divide) were considered by some Italians and Italian-American immigrants as a means to differentiate themselves from other categories in the United States social composition (particularly African-Americans and the recently Americanized Jews.) Mussolini realized that support for his plans could come from the Italian immigrants in the United States. In 1921, journal editor Agostino De Biasi (1875-1964) founded the Fascio of New York establishing a direct chain of communications between Italy and the United States. ${ }^{424}$ Mussolini envisaged the formations of hundreds of Fasci in the United States to "arouse, conserve, and exalt Italianità among the millions of fellow Italians dispersed throughout the world." ${ }^{, 425}$ As leader of the Order of the Sons of Italy in Philadelphia, Giovanni Di Silvestro planned to transform the Order as the representative

\footnotetext{
${ }^{424}$ Fascio is the metaphorical name for the band of Mussolini's followers, called fascisti. Gaetano Salvemini, Italian Fascist Activities in the United States (New York: Center for Migration Studies: 1977), 12-15; Philip V. Cannistraro, Blackshirts in Little Italy: Italian Americans and Fascism 1921-1929 (West Lafayette: Bordighera Press, 1999), 8-23.

${ }^{425}$ Benito Mussolini, Il Popolo d'Italia, 1921, 2 May 1921; Gaetano Salvemini, Italian Fascist Activities in the United States (New York: Center for Migration Studies: 1977), 12-15; Philip V. Cannistraro, Blackshirts in Little Italy: Italian Americans and Fascism 1921-1929 (West Lafayette: Bordighera Press, 1999), 8-23.
} 
body in Italian American relations with the Fascist regime. In Mussolini's design, Italian immigrants and their descendants were to claim United States citizenship in order to create a lobbying pro-Italy group. In his plans, this strategy would influence American foreign policy to favor Italy. ${ }^{426}$ Italians in America felt for the first time that they were important to Italy's nationalistic agenda. But they did not really "feel” Italian nor had they ever done. Similarly, they were not Americans. They had become an in-between group.

\section{Miami and Its Adjoining Neighborhoods}

Little Italys were safe havens for Italians immigrating to established Englishspeaking worlds, but the few Italians who chose Miami and Southeast Florida moved freely in this new Caribbean environment because all groups and nationalities were pioneers still negotiating spaces. We have already seen how Abulafia refers to spaces where cultural exchanges take place with the term "Mediterranean". I call them “mediterranean”, which means space in-between lands. ${ }^{427}$ Analogously, the liquid space between the Northern and Southern American continents is also mediterranean, the "Mediterraneo-Caribe" proposed by Cuban intellectuals Lezama Lima (1910-76) and Alejo Carpentier (1904-80). ${ }^{428}$ Like the Mediterranean Sea, the mediterraneo-Caribe is

\footnotetext{
${ }^{426}$ Emilio Gentile, "La Politica Estera del Partito Fascista. Ideologia e Organizzazioned Dei Fasci Italiani All'estero (1920-1930)," Storia Contemporanea XXVI, no. 6 (1995).

${ }^{427}$ David Abulafia, "Mediterraneans," in Rethinking the Mediterranean, in Rethinking the Mediterranean, William V. Harris (Oxford: Oxford University Press, 2005), 64-93.

${ }^{428}$ Benitéz Antonio Rojo, “Alejo Carpentier: Between Here and Over There," Caribbean Studies 27, no. 3/4 (1994): 183-95; Lezama José Lima, Selections, <ed.> Livon-Grosman, Ernesto
} 
open to the ocean, which brings more exchanges. Like Italy, Florida protrudes in a mediterranean space. In the last decades of the nineteenth century, Florida, and in particular Miami and its neighbouring areas, still retained an insular identity that the newly arrived entrepreneurs Julia Tuttle (1849-98) and Henry Flagler (1830-1913) would soon reveal, opening its shores to cultures as Italy had done in the Mediterranean Sea. Miami and Southeast Florida had a receptivity to accept and transform foreign influences because their coastal shores had the insular sensibility that Lozama Lima called "resaca" (undertow). ${ }^{429}$ Southeast Florida's pioneers welcomed Italian culture as one of many ingredients that composed the Mediterranean civilizing world; they blended with American modernism and displayed in the Caribbean environment. The continual conversation between seascape and cultures allowed the many different groups living in Miami and Southeast Florida to move freely in spaces without borders. Interestingly, the Italian labor force that reached Miami and Southeast Florida in the last decade of the nineteenth century did not import symbols and signs of what it meant to be Italian. Undertows of Italian memory had preceded them. They found a world already infused with Italianità and asking for more.

(Berkley and California: University of California Berkley, 2005); Marco Katz, "Not India, in Which Alejo Carpentier and Zora Neale Hurston Finally Discover America," Bibliothèque et Archives Canada Direction du Partrimoine de l'édition (2011): 1-344Edmonton: University of Alberta, 2011.

${ }^{429}$ Lezama José Lima, Selections, <ed.> Livon-Grosman, Ernesto (Berkley and California: University of California Berkley, 2005), 180. 


\section{Conclusion}

The adjustments by Italian immigrants to life in New York and Philadelphia depended on many variables. The character and the place of origin of the newcomers, the host societies they found, and their skills played a major role in their integration. Immigrants of an earlier time (before the 1860s) were more skilled and had higher levels of literacy. The majority of them had left the Northern regions of Italy with the intention to remain in the Americas. They moved to unexplored land within the United States, and did not feel the necessity to cluster with kinsfolk and people with the same place of origin. All these characteristics gave them the advantage to assimilate and make their fortunes both economically and socially. The host society received them without reserve and discrimination. The more educated in the receptive audience perceived the individuals coming from the Italian peninsula as worthy representatives of what they knew about the Italian culture. After the 1860s, things changed.

Italy's 1861 unification only existed in a newly drafted constitution. Italians remained loyal to the village mentality that they had already known. This "campanilismo" (village loyalty) had protected and supported them through foreign domination and exploitation at the hands of local rulers. The Italian government sanctioned the racial division of Italy's population that marked Northerners and Southerners. With this label, after the 1860s, a growing number of Italians left Italy for the United States. Unskilled peasants gathered in the center of American big cities and looked for blue-collar jobs. Jobs that could be performed without any particular skill were paid accordingly. In the majority of cases, Italian immigrants earned some money, but their living circumstances were pitiful. Few of them emerged and progressed and 
established successful businesses. The United States had a vital middle class and it took determination and entrepreneurial skill to become a part of it. Of these classes, none seemed to fit peasants who lived in the center of industrial cities.

In the years 1870 to World War I, the United States needed construction and industrial workers. Most of the other niches had already been occupied by native-born Americans and by earlier immigrants. Italian immigrants who arrived in those years suffered from the plight of their country of origin. They were victims also of unfavorable historical and economic junctures in the United States. Vertical mobility in this new country was possible, but harder to achieve, mainly for those who were labeled as immigrants from South Italy.

Not only was the host society prone to negative perceptions of Italians, particularly of those from South Italy, but Italian Northern immigrants also discriminated against their Southern compatriots. Southerners only trusted those who came from their same place of origins. They gathered according to their birthplaces, within strict boundaries that protected them from hostility and racism. These people did not simply think that it was easier for them to live with individuals who spoke their same dialects and shared the same beliefs. They clustered with kinfolks, relatives, and friends because they perceived their otherness from the host population. Scholars have spoken of the "Italo-phobia" of the English-speaking world. The United States' institutions looked at immigrants from South Italy, and in 1924 also more broadly to those from South Europe, 
as threats to the Northern race. ${ }^{430}$ The historiography of Italian emigration does not show evidence of Little Italys in Brazil, Argentina, or France, and neither in Miami and Southeast Florida. Certainly the fact that these were not exclusively English-speaking and Protestant societies makes for a good explanation. Obviously, Miami's and Southeast Florida's inconsequential number of Italian immigrants is also another good reason. Why then this area of the United States was so full of symbols of Italianità is the topic of the next chapter.

${ }^{430}$ This refers to the Immigration Act of 1924 that limited the yearly number of immigrants admitted to the United States. See Chapter 2 for more details. 


\title{
CHAPTER 4
}

\section{FROM PICTURESQUE TO MAGIC}

\author{
- Look, look, there's Miami! \\ - Where? Where? \\ - Why, right there in front of us" \\ - But where's the town? \\ That's it. ${ }^{431}$
}

The Sewell brothers, John (1867-1938) and Everest George (1874-1940), arrived with twelve black laborers at the outpost called Miami on March 8, 1896. Henry Flagler (1830-1913), the founder of the Florida East Coast Railway (FEC), had sent John, foreman and superintendent for the FEC, to clear the area for the construction of the Royal Palm Hotel and to organize the extension of the railroad from Palm Beach to Miami. The men arrived aboard Flagler's ship Della. The brief conversation in the opening citation above took place between the ship's captain and John Sewell, as the palm-fringed land appeared to the brothers when they approached the mouth of the Miami River. ${ }^{432}$ It well expresses what Miami looked like in 1896. John Sewell later wrote

${ }^{431}$ Arva Moore Parks, "The Daddy of Miami," in Memoirs and the History of Miami, by John Sewell (Miami: Arva Parks \& Co., 1987), ix.

${ }^{432}$ John Sewell, Memoirs and History of Miami, Florida (Miami: The Franklin Press, Inc., 1933), 8. 
I found Miami all woods. Mrs. Tuttle had opened up Avenue D from the Miami river north to 14th Street, and I also found several little shacks and tents started on this street. Also Mrs. Tuttle had started to build the Miami Hotel located east of Avenue D and south of the spur railroad track leading down to the Royal Palm Hotel site. The spur track was graded at that time. The Miami Hotel was enclosed enough to open up like a camp. ${ }^{433}$

Business woman Julia Tuttle (1849-1898), had arrived in the area from Cleveland in the 1870s, after her husband's death. She had bought 640 acres on the north bank of the Miami River with the money obtained from the sale of the iron foundry inherited from her husband. Tuttle also invested in the construction and management of Miami's first hotel, the Hotel Miami, but soon realized that her land and investment would never prosper unless Flagler's trains, and with them people and business, reached Miami. A few months before the Sewells' arrival, Tuttle had convinced Henry Flagler to extend the FEC from Palm Beach to Miami. On April 22, 1896, Flagler's first passenger train reached the little shacks and tents in the woods at the mouth of the Miami River, and on July 28, 1896, Miami was incorporated "with some five hundred and two voters". ${ }^{434}$ If the community at that time included Italians, they did not leave any traces. What already existed at this early stage of Miami's life, however, was the cultural construction of what it was to be "the other Mediterranean" for the Anglo settlers and entrepreneurs living in this region. It was via this construction that Italianità crossed the Atlantic and turned into

\footnotetext{
${ }^{433}$ John Sewell, Memoirs and History of Miami, Florida (Miami: The Franklin Press, Inc., 1933), 11.

${ }^{434}$ John Sewell, Memoirs and History of Miami, Florida (Miami: The Franklin Press, Inc., 1933), 53.
} 
one of the many ingredients of a new Mediterranean style in Southeast Florida that also included French, Moorish, Greek, and Spanish elements.

The terminology of performance is recurrent in the language used by art historians, art critics, and architects. Art critic Dave Hickey said of Italian Renaissance architect Andrea Palladio (1508-80) that he was "never impersonating classical

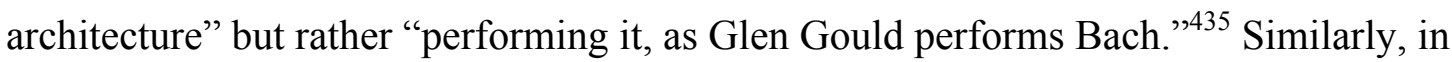
their discussion of large construction projects in the early twentieth century, Witold Rybczynski and Olin Laurie argued that American architects "performed” European architectural styles. ${ }^{436}$ In the same vein, Italianità in Southeast Florida did not impersonate Italian characters but it was the pioneers' representation à la italiana of their understanding of Italian culture and identity within a Mediterranean frame of reference. In the new Southeastern frontier, entrepreneurs "borrowed from different styles, interpreted, combined, adapted them and arrived at a synthesis that responded to local factors in the fashionable vocabulary of the day" by inventing a new Mediterranean Style, where Italian elements merged with features from other cultures and became eminently an American version of it. ${ }^{437}$ This chapter charts these cultural constructions and interprets how an hybrid form of Italian culture was 'recreated' on the Southern Atlantic

${ }^{435}$ Dave Hickey, “A House Undivided,” Harper's Magazine (2003): 69.

${ }^{436}$ Witold Rybczynski and Olin Laurie, Vizcaya: An American Villa and Its Makers (Philadelphia: University of Pennsylvania Press, 2007), 18.

${ }^{437}$ Rexford Newcomb, Mediterranean Domestic Architecture in the United States (Cleveland: J. H. Hansen, 1928), 2; Ivan Rodriguez, From Wilderness to Metropolis: The History and Architecture of Dade County (1825-1940) (Miami: Metropolitan Dade County Office of Community Development Historic Preservation Division, 1992), 102. 
coast, despite the absence of any significant Italian community, through the evaluation not only of works of art and architecture, but also of unwritten codes, symbols, gestures, and common attitudes.

\section{Picturesque Miami}

Few places could have been less suitable to place a city than this former military outpost, established during the Seminole wars. ${ }^{438}$ One pioneer, E. V. Blackman (1845-?) commented that Miami had "never been a village or town, but was born a full-fledged

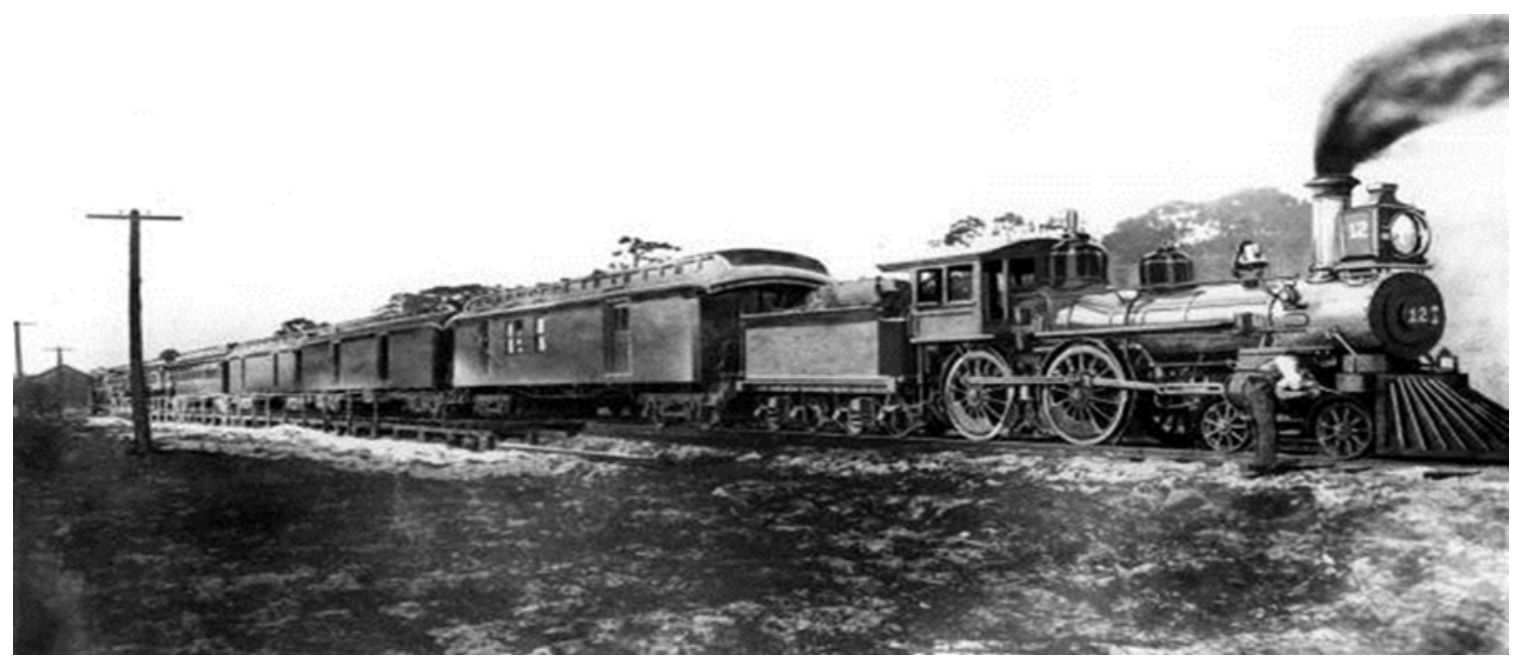

Figure 17. Arrival of the first passenger train to Miami, April 1896. State Archives of Florida, Florida Memory, http://floridamemory.com/items/show/29386.

${ }^{438}$ It was formerly called Fort Dallas (built in 1836) and served as military outpost and temporary accommodation of troops, more than as a fortification, during the second of the three wars between United States' forces and various groups of Florida Native Americans. The first war was fought from 1814 to 1819 , the second war from 1835 to 1842 , and the last one from 1855 to 1858 . 
city," an observation that reflects the fact that entrepreneurs like Tuttle and Flagler strongly wanted and rationally planned the community from the beginning. ${ }^{439}$ Flagler was prophetic in his vision of a city full of activities, packed with tourists staying in the hotels that he was going to build, and traveling by FEC trains along the Eastern coast of the United States down to its Southernmost tip. He reportedly commented that

Others have built churches, libraries and schools; these will all pass away with time and the givers will be forgotten. But the building of the Florida East Coast Railroad and the opening up of a wilderness will not, I am sure, be effaced by time, but rather will grow in value as the years go by and as the people come in and possess the land. ${ }^{440}$

To many of his contemporaries, the project seemed doomed to failure. For example, Samuel Sloan (1815-1884), president of Delaware and Lackawanna Railroad, said publicly that it would be impossible for Flagler to form a group of capitalists to build the Florida East Coast Railroad and to make other developments in what he considered to be a worthless region. ${ }^{441}$ Flagler proved him wrong. Along with Julia Tuttle and other developers, he built the infrastructure to accommodate visitors who had been turned south by the closure of the European Rivieras of Italy, France and other Mediterranean seasides. ${ }^{442}$ Conventional iconography presents Flagler and Tuttle as the father and the

\footnotetext{
${ }^{439}$ E.V. Blackman, Miami and Dade County, Florida: Its Settlement, Progress and Achievement (Washington: Victor Rainbolt, 1921), 19.

${ }^{440}$ E.V. Blackman, Miami and Dade County, Florida: Its Settlement, Progress and Achievement (Washington: Victor Rainbolt, 1921), 51.

${ }^{441}$ E.V. Blackman, Miami and Dade County, Florida: Its Settlement, Progress and Achievement (Washington: Victor Rainbolt, 1921), 52.

${ }^{442}$ In the second half of the 19th century, Europe, which had been experiencing strong economic growth fuelled by the Second Industrial Revolution, became the theater of liberal uprisings to crush
} 
mother of Miami, the two idealists who dreamed the development of the "city of eternal youth" and the realization of Miami's future greatness. ${ }^{443}$ More prosaically, they were among the first speculators to recognize the opportunities associated with the yet unexploited Southeastern areas of Florida.

Tuttle and Flagler belonged to the second wave of pioneers who pushed the American frontier into the new Southeastern Atlantic region, where they established another version of American life. They arrived after a first wave that had begun settling in the region in 1808. This first group was composed of individuals more concerned with mere subsistence. ${ }^{444}$ As Baptist missionary John Mason Peck (1789-1858) argued in 1837, a cabin and a fenced land were enough for these first settlers, before "another wave rolls on" and "the men of capital and enterprise come." ${ }^{445}$ In addition to Tuttle and Flagler, the second wave brought individuals such as William P. Wagner (1825-1901), Adam C. Richards (1849-?), William B. Brickell (1817-1908), William G. Gleason (1858-1932), Charles Ewing (1869-1932), and E. T. Sturtevant (Tuttle's father). ${ }^{446}$

conservative governments. These revolts affected all Europe with the exception of Russia and the United Kingdom.

${ }^{443}$ E.V. Blackman, Miami and Dade County, Florida: Its Settlement, Progress and Achievement (Washington: Victor Rainbolt, 1921), 57; 59.

${ }^{444}$ E.V. Blackman, Miami and Dade County, Florida: Its Settlement, Progress and Achievement (Washington: Victor Rainbolt, 1921), 11-16.

${ }^{445}$ John Mason Peck, A New Guide for Emigrants to the West: Containing Sketches of Michigan, Ohio, Indiana, Illinois, Arkansas, with the Territory of Wisconsin and the Adjacent Parts (Mississippi River Valley: Gould, Kendall, \& Lincoln, 1837).

${ }^{446}$ Dates unknown. 
In 1893, historian Frederick Jackson Turner (1861-1932) advanced the thesis that the American frontier emancipated Americans from old European mind-sets. ${ }^{447}$ According to Turner, frontiers eroded the dysfunctional customs of European societies built on established armies and churches and on hierarchical, aristocratic structures. As frontier land was free for the taking, it represented democracy. Turner also argued that the process of American evolution advanced by turning the primitive conditions found in wilderness into more complex forms of civilization.

Now the peculiarity of American institutions is the fact that they have been compelled to adapt themselves to the changes of an expanding people -- to the changes involved in crossing a continent, in winning a wilderness, and in developing at each area of this progress out of the primitive economic and political conditions of the frontier into the complexity of city life. ${ }^{448}$

Tuttle, Flagler, and the second-wave entrepreneurs arriving in Southeast Florida were determined to turn the wilderness they found into metropolises. They bought and sold land and elevated small communities to the rank of spacious towns or cities, where

substantial edifices of brick, extensive fields, orchards, gardens, colleges, and churches are seen. Broad-cloths, silks, leghorns, crepes, and all the refinements, luxuries, elegancies, frivolities, and fashions are in vogue. ${ }^{449}$

\footnotetext{
${ }^{447}$ Frederick Jackson Turner, "The Significance of the Frontier in American History," conference presentation at the 1893 World's Columbian Exposition, American Historical Association (Chicago, 1893).

${ }^{448}$ Frederick Jackson Turner, “The Significance of the Frontier in American History,” conference presentation at the 1893 World's Columbian Exposition, American Historical Association (Chicago, 1893), introduction.

${ }^{449}$ Frederick Jackson Turner, “The Significance of the Frontier in American History,” conference presentation at the 1893 World's Columbian Exposition, American Historical Association (Chicago, 1893).
} 
It is significant to note how in the entrepreneurs' minds the edifices and frivolities of burgeoning Miami community took the form and shapes of Mediterranean and Italian styles.

In part because of geographical similarities, Florida was often advertised to the American public as "the American Italy, the new American Riviera for pleasure-loving citizens. ${ }^{450}$ Homes, hotels, land, and railways made for good investments that Miami’s entrepreneurs marketed strategically. The Royal Palm Hotel, "the largest and most significant building associated with the Florida East Coast Railroad in Miami”, opened in January $1897 .{ }^{451}$ It could accomodate over 500 guests. According to an article published that same year in The Tatler, Flagler's hotel newspaper in St. Augustine, the Royal Palm Hotel's architecture was "Italian Renaissance or, to use a more American term, Colonial, of perfect proportions. ${ }^{, 452}$ It is remarkable that the writer merged two architectural styles, Colonial and Italian Renaissance, by explaining "Italian Renaissance" with a "more American term, Colonial.",453

The Royal Palm Hotel was a pastiche of Italian and other European architectural styles adapted for mainstream American tastes. Architect and historian Ivan Rodriguez

${ }^{450}$ Edward King, “The Great South,” Scribner's Monthly IX, no. November, 1874 (1874): 3; Theyre Hamilton Weigall, Boom in Paradise (New York: Alfred H. King, 1932), 37; 40; 221.

${ }^{451}$ Ivan Rodriguez, From Wilderness to Metropolis: The History and Architecture of Dade County (1825-1940) (Miami: Metropolitan Dade County Office of Community Development Historic Preservation Division, 1992), 24.

452 “The Royal Palm,” The Tatler, 1897, 16 January 1897, 3.

453 “The Royal Palm,” The Tatler, 1897, 16 January 1897, 3. 
argues that its design was not of the caliber of the other resorts and hotels that Flagler had built in Florida because, as the railroad moved south, opening new vacation frontiers, Flagler had to channel finances and labor forces in many directions. ${ }^{454}$ James A. McGuire and Joseph A. McDonald (1842-1918), building contractors for the F.E.C. Corporation, built the hotel, with a wood frame structure (like the props for a theatrical performance), in less than one year. ${ }^{455}$ The hotel had a French-inspired design, the one originally used for Flagler's Royal Poinciana Hotel in Palm Beach, which had been finished only two years earlier, and displayed both Colonial and Italian Renaissance features. ${ }^{456}$ The major decorative feature was its

mansard roof dotted with dormers, and an entrance portico of classical derivation that was centered on the north elevation, five bays wide and two stories in height, culminating the main palm-lined approach through the grounds. ${ }^{457}$

${ }^{454}$ Ivan Rodriguez, From Wilderness to Metropolis: The History and Architecture of Dade County (1825-1940) (Miami: Metropolitan Dade County Office of Community Development Historic Preservation Division, 1992), 24.

${ }^{455}$ Susan Braden, The Architecture of Leisure: The Florida Resort Hotels of Henry Flagler and Henry Plant (Gainesville: University Press of Florida, 2002); Ivan Rodriguez, From Wilderness to Metropolis: The History and Architecture of Dade County (1825-1940) (Miami: Metropolitan Dade County Office of Community Development Historic Preservation Division, 1992), 24-5.

${ }^{456}$ Ivan Rodriguez, From Wilderness to Metropolis: The History and Architecture of Dade County (1825-1940) (Miami: Metropolitan Dade County Office of Community Development Historic Preservation Division, 1992), 25.

${ }^{457}$ Ivan Rodriguez, From Wilderness to Metropolis: The History and Architecture of Dade County (1825-1940) (Miami: Metropolitan Dade County Office of Community Development Historic Preservation Division, 1992), 25. 


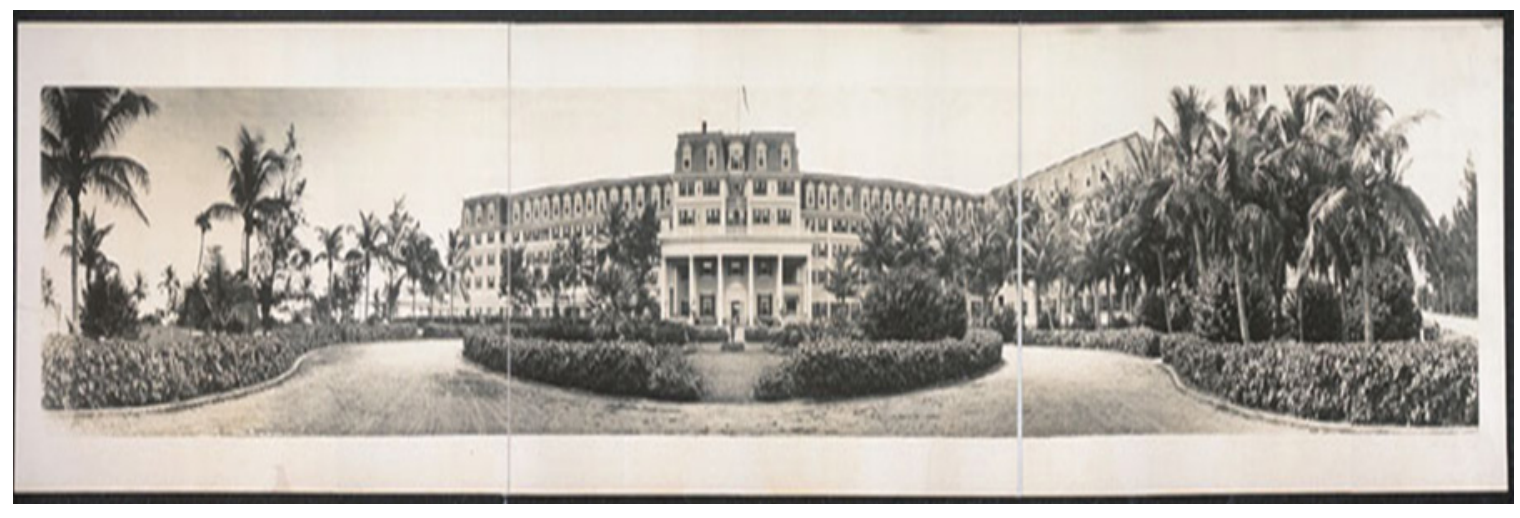

Figure 18. Royal Palm Hotel. Photograph, 192-.Source: State Archives of Florida, Florida Memory, http://floridamemory.com/items/show/5496.

Needless to say, those elements were far from the classical Italian architecture they proposed to recreate. According to art historian Susan Braden, architectural eclecticism became common after the 1876 Centennial exposition in Philadelphia. ${ }^{458}$ The fair marked the rebirth of Americans' interest in the architecture of their own colonial past, leading architects to begin incorporating their own notions of what they called European Renaissance ideals into the American Colonial Revival style. ${ }^{459}$

Colonial Revival features included clapboarding, white classical trim, neat window shutters, and a mansarded roof. The Italian Renaissance was epitomized by a

${ }^{458}$ The Centennial Exposition or International Exhibition of Arts, Manufactures and Products of the Soil and Mine was the first world fair exposition in the United States. It was held in Philadelphia.

459 Braden, Susan R. "Florida Resort Architecture: The Hotels of Henry Plant and Henry Flagler." Order No. 8805648, The Florida State University, 1987.

http://ezproxy.fiu.edu/login?url=http://search.proquest.com/docview/303466376?accountid=10901, 56-7; see also the book published from the dissertation, Susan Braden, The Architecture of Leisure: The Florida Resort Hotels of Henry Flagler and Henry Plant (Gainesville: University Press of Florida, 2002). 
two-story, 50 by 100 foot rotunda placed at the center of the main building. ${ }^{460}$ Braden writes that the rotunda was "the heart of the Royal Palm's interior." 461 The rotundas in Thomas Jefferson's Monticello estate and at the University of Virginia confirm the longstanding American interest in this particular Italian architectural feature, inspired by Andrea Palladio. ${ }^{462}$ It is noteworthy that the Royal Palm included an Italian Renaissance mark, the rotunda, as its central feature, "an established symbol of great-hall welcome as well as a social and circulation hub." ${ }^{263}$ Beautifully landscaped gardens completed the layout of the hotel, highlighting as major physical asset —its site. ${ }^{464}$

\footnotetext{
${ }^{460}$ The Centennial Exposition or International Exhibition of Arts, Manufactures and Products of the Soil and Mine was the first world fair exposition in the United States. It was held in Philadelphia. Braden, Susan R. "Florida Resort Architecture: The Hotels of Henry Plant and Henry Flagler." Order No. 8805648, The Florida State University, 1987. http://ezproxy.fiu.edu/login?url=http://search.proquest.com/docview/303466376?accountid=10901, 169.

${ }^{461}$ The Centennial Exposition or International Exhibition of Arts, Manufactures and Products of the Soil and Mine was the first world fair exposition in the United States. It was held in Philadelphia. Braden, Susan R. "Florida Resort Architecture: The Hotels of Henry Plant and Henry Flagler." Order No. 8805648, The Florida State University, 1987.

http://ezproxy.fiu.edu/login?url=http://search.proquest.com/docview/303466376?accountid=10901, 169.

462 Thomas Jefferson (1743-1826), author of the American Declaration of Independence and third president of the United States, was also a talented architect of neoclassical buildings. He designed Monticello (1769-1809), his plantation home, and his ideal 'academical village' (1817-26), which is still the heart of the University of Virginia. See UNESCO/CLT/WHC, http://whc.unesco.org/en/list/442. Jefferson used an architectural vocabulary inspired by the work of the Italian Renaissance architect Andrea Palladio (Andrea di Pietro della Gondola, 1508-1580), and called Palladio's The Four Books of Architecture "the Bible." See Calder Loth, "Palladio's Influence in America," Virginia Department of Historic Resources (Virginia, 2008), 1. Several of Palladio's projects had symmetrical plans with a central circular hall. See, for example, Villa Capra (also known as Villa Rotunda, 1566-71).

${ }^{463}$ The Centennial Exposition or International Exhibition of Arts, Manufactures and Products of the Soil and Mine was the first world fair exposition in the United States. It was held in Philadelphia.

Braden, Susan R. "Florida Resort Architecture: The Hotels of Henry Plant and Henry Flagler." Order No. 8805648, The Florida State University, 1987.

http://ezproxy.fiu.edu/login?url=http://search.proquest.com/docview/303466376?accountid=10901, 170.
} 
McGuire's and McDonald's preoccupation with position, (including the impressive view of Biscayne Bay at the mouth of the Miami River), architecture, and landscape showed the Picturesque Movement's influence on Miami’s urban planning. ${ }^{465}$ The term 'picturesque', pittoresco in Italian, translates into "that peculiar kind of beauty, which is agreeable in a picture" (pittura), as art historian William Gilpin (1724-1804) described it in $1792{ }^{466}$ This peculiar kind of beauty belonged not only to architectural details, but also to people, languages, animals, and landscapes. By the late $19^{\text {th }}$ century, American intellectuals were concerned with researching what made the 'American picture' modern and, as such, unique. ${ }^{467}$ Both intellectual Randolph Bourne (1886-1918) and writer Henry James (1843-1916) were interested in this theme. Bourne supported the idea that immigrants constituted the "antithesis of fusion" that composed trans-National America, where the diversity of immigrants represented the picturesque element of American unity. ${ }^{468}$ For James, instead, picturesque was the bucolic quality that he had

\footnotetext{
${ }^{464}$ Ivan Rodriguez, From Wilderness to Metropolis: The History and Architecture of Dade County (1825-1940) (Miami: Metropolitan Dade County Office of Community Development Historic Preservation Division, 1992), 24-5.

${ }^{465}$ The Picturesque Movement was a style born in England in the nineteenth-century. See Braden, Susan R. "Florida Resort Architecture: The Hotels of Henry Plant and Henry Flagler." Order No. 8805648, The Florida State University, 1987. http://ezproxy.fiu.edu/login?url=http://search.proquest.com/docview/303466376?accountid=10901, 60.

${ }^{466}$ William Gilpin, An Essay on Prints (London: R. Blamire, 1792), xii..

${ }^{467}$ Randolph Bourne, "Trans-National America," in War and the Intellectuals, Carl Resek (New York: Harper \& Row, 1964), 107-23; Carrie Tirado Bramen, "The Urban Picturesque and the Spectacle of Americanization," American Quarterly 52, no. 3 (2000): 444-77.

${ }^{468}$ Randolph Bourne, "Trans-National America," in War and the Intellectuals, Carl Resek (New York: Harper \& Row, 1964), 107-23.
} 
appreciated in a long sojourn in Italy. While visiting Albano, a little village south of Rome in the 1870s, he said "I have talked of the picturesque all my life; now at last...I see it. ${ }^{3469}$ The informal aesthetics born in Europe at the end of the eighteenth century, which synthesized classical art with informal details of peculiar beauty, spread to the United States. ${ }^{470}$ The new fashion influenced American architects who further transformed styles of European origins into an American product by adding regional 'picturesque' elements. With the Royal Palm Hotel, the diverse people arriving with Flagler's train, and Miami's still rustic nature, gave the new city a true 'peculiar' beauty that distanced it from the Northern cities of America where little Italies emerged. The Royal Palm set the leitmotif for Miami's future character of metropolis born from the orchestrated merging of Mediterranean identities in an American frontier.

\section{The New Mediterranean-Caribbean Frontier}

The new frontier "created a demand for merchants" when, as the frontier rippled out the Northern states, it became important for developers and entrepreneurs to take action and produce and exchange supplies of all sorts ${ }^{471}$ One of the effects of the region's new trades was the birth of merchants expert in modern marketing strategies.

\footnotetext{
${ }^{469}$ James Buzard, "The Grand Tour and After (1660-1840)," in The Cambridge Companion to Travel Writing, Peter Hulme and Tim Youngs (Cambridge: Cambridge University Press, 2002), 37-52.

${ }^{470}$ See for example Osterley Park building (1763-1780) in London, by architect Robert Adam (1728-1792). What makes Osterley Park Picturesque is the 'movement' of its complex silhouette, made of a flat front, towers, central pavilion, temple-front pavilion, and contrasting materials.

${ }^{471}$ Frederick Jackson Turner, “The Significance of the Frontier in American History," conference presentation at the 1893 World's Columbian Exposition, American Historical Association (Chicago, 1893).
} 
Miami's builders and entrepreneurs became forerunners in modern advertising, a field where, in the first years of the $20^{\text {th }}$ century, the United States was already a leader. ${ }^{472}$ They were determined to sell a dream and planned its marketing strategically. The promoters constructed their advertisements with certain features. A single component dominated the area - a picture, headline (e.g., Venetian Islands in Biscayne Bay), or texts such as that of the 1915 brochure Chicago-Miami: Magic Miami, the City of Inspiration and the Southern Terminus of the Dixie Highway. ${ }^{473}$ Promoters crafted their message according to the intended audience. For example, in the brochure "Chicago-Miami" mentioned above, Miami civic officials and businessmen hinted at the beaches, rocky clefts, summer air and "a winter air that invigorates but never destroys" to lure Midwesterners to the Southern reaches of the American frontier, where the sky was "blue as that of Italy." 474 They also supported their promises with case histories, charts, and statistics. In the same pamphlet, prepared "to encourage potential businesses, agricultural investors, and commercial interests to consider the advantages of relocating to South", the Board of Trade provided data that compared the climates of Italy, Spain,

\footnotetext{
${ }^{472}$ Giuseppe Prezzolini, America in pantofole. ragguagli intorno la trasformazione degli Stati Uniti dopo le guerre mondiali (Firenze: Vallecchi Editore, 1950).

${ }^{473}$ C. H. Ward, The Lure of the Southland: Miami and Miami Beach, Florida, promotional pamphlet, 1915 (Coral Gables: University of Miami Special Collections). Venetian Islands in Biscyne Bay, brochure, Wolfsonian-FIU Rare Books and Special Collections Library.

${ }^{474}$ C. H. Ward, The Lure of the Southland: Miami and Miami Beach, Florida, promotional pamphlet, 1915 (Coral Gables: University of Miami Special Collections).
} 
and France with that of Florida. ${ }^{475}$ They organized their advertisements sequentially, caught the audience's attention and guided it gradually to the selling proposition; used an individualized form of address; emphasized the product, and then the sellers' names; portrayed what they liked, and so exposed their dispositions. ${ }^{476}$ Americans constituted an avid audience. In 1925, the poet Majakovskij wrote that on Sundays the average American read a newspaper of a hundred pages and two pounds of weight, employing an hour just to flip through the pages of the colorful advertising "on which he based his view of the world. ${ }^{, 477}$

The real estate market in Miami and adjacent neighborhoods soared. Southeast Florida's pioneers were busy buying and selling lands and services and always looking for new ways of profiting from their investments. Carl Fisher (1874-1939), John Collins (1837-1928), and George Edgar Merrick (1886-1942) continued what Henry Flagler and Julia Tuttle had initiated. Collins was an elderly Quaker who arrived in South Florida in 1906 to run a coconut plantation he had started few years earlier and left to an attendant and to start the cultivation of tropical fruits. In order to facilitate transportation to his plantations, he began the construction of a wooden bridge to connect Miami to the barrier

\footnotetext{
${ }^{475}$ C. H. Ward, The Lure of the Southland: Miami and Miami Beach, Florida, promotional pamphlet, 1915 (Coral Gables: University of Miami Special Collections).

${ }^{476}$ This sort of vademecum for perfect advertisements comes from the column "Copy Chasers" in the magazine Business Marketing, quoted in Jim Rhodes, "Ten Rules for Good Advertising," blog entry, Jim Rhodes (Norfolk, 2012). See also Souvenirs of Miami: 100 Years of Promotional Literature, University of Miami Special Collections, Otto G. Richter Library, Coral Gables, Florida.

${ }^{477}$ Vladimir Majakovskij, My Discovery of America, reprint, 1st ed. 1926 (London: Hesperus Press, 2005), 56.
} 
island between Biscayne Bay and the Atlantic Ocean, which would become Miami Beach. Fisher, who was a self-made millionaire from Indiana, moved to Miami in 1912. In exchange for two hundred acres of the island's oceanfront land, he invested in Collins' building enterprise and in the construction of the wooden bridge. In 1913, the construction of the longest wooden bridge in the world was concluded, making the fortune of Miami by bringing more tourism and business. George Edgar Merrick, the son of a New England pastor, began his business career selling citrus produce from his father's plantation door-to-door. His mule and wagon full of citrus was a familiar sight around Miami in the years following his arrival in $1898 .{ }^{478} \mathrm{He}$ developed Coral Gables and promoted improvements and innovations in urban planning in the 1920s, such as the construction of U.S. 1, the Tamiami Trail, Old Cutler Road, and the Miami Canal Highway. In 1925, Merrick donated the land and the funds necessary to build the University of Miami. ${ }^{479}$

From 1896 to 1939, Miami's boosters used the Mediterranean, and Venice in particular, as marketing tools to sell property in Florida. In the promotional literature of the period, Venice recurred as an established symbol of mercantile Italy. Writer and conservationist Marjorie Stoneman Douglas (1890-1998), who was born in Minneapolis,

\footnotetext{
${ }^{478}$ Ivan Rodriguez, From Wilderness to Metropolis: The History and Architecture of Dade County (1825-1940) (Miami: Metropolitan Dade County Office of Community Development Historic Preservation Division, 1992), 76; 106

${ }^{479}$ Ivan Rodriguez, From Wilderness to Metropolis: The History and Architecture of Dade County (1825-1940) (Miami: Metropolitan Dade County Office of Community Development Historic Preservation Division, 1992), 76; 106. David Nolan, Fifty Feet in Paradise: The Booming of Florida (San Diego: Harcourt Brace Jovanovich, 1984).
} 
moved to Miami in 1903 to work with her father, Frank Stoneman, founder and publisher of the Miami Evening Record (later renamed The Miami Herald.) Stoneman Douglas authored the column "The Galley" in the Miami Herald from 1920 to 1923. In the column, which always included a poem, she talked about Florida "as landscape and as geography, to investigate it and to explore it. ${ }^{480}$ She frequently compared Miami to Venice, which she depicted as an unattainable dream place

Would like to be in Venice, right now, instead of in Miami? Well, the other night, over at Miami Beach with a certain sunset burning in splendor, it was just as good as going in swimming at the Lido at Venice. ${ }^{481}$

This is precisely why there was not a Little Italy in Miami: the entire city was conceived as a Mediterranean pastiche with Italian overtones. The number of Italians in residence was not necessarily what made it Italian but rather the new conceptualization of Italianità turned into Mediterraneità in Miami and the Caribbean. Stoneman Douglas filled her long editorials with memories of travels to Italy and comparisons of Venice and Miami, Adriatic and Atlantic, Italian and American characters. Likely readers appreciated her admiration for Venice and for what it represented. In the piece entitled Venice to Miami

Venice - ah, there was a city, a dream and a wonder Rising in radiant gold from the green of the sea, Scarlet banners that beat to the bronze bells' thunder, The glory of Venice was. But ours shall be. Venice - ah, there was a city, great-hearted they made her Out of a swamp and a vision, one glorious gem.

They lifted her, they, the Venetians, the merchant, the trader.

\footnotetext{
${ }^{480}$ Marjory Stoneman Douglas, Voice of the River (Sarasota: Pineapple Press Inc., 1990), 127.

${ }^{481}$ Marjory Stoneman Douglas, "The Galley,” The Miami Herald 12, no. 265 (1922, 17 August
} 1922): 8 . 
Shall never a city share that glory with them?

Venice - ah, Venice, scarlet your banners are crying

Across to us here, "Have you not also the sea?

Is not the sky as blue over you lying?

The glory of Venice was. But yours shall be. ${ }^{482}$

Pieces such as this drew a strong parallelism between Venice and Miami, highlighting the commercial vocation and the similarities between the geographical and socioeconomic aspects of the two cities. Venice had been Italy's ambassador to the Orient and one of its leading trading centers ("the glory of Venice was"), while Miami was the place in the United States to amass new economic riches ("but yours shall be".) ${ }^{483}$ The poem illustrates that Stoneman Douglas was directly marketing Miami to the inhabitants of the Northern States rather than writing and publishing a reflection of what she thought of Miami. In The Galley, Venice possessed iconic symbols of an identity that had declined in the old world (the merchant and the trader, Marco Polo's heirs, who lifted the city to become a dream city, a wonder, a gem) but that was now being resurrected on the other side of the Atlantic. Stoneman Douglas saw Miami as the gateway between past and present and as the place elected to preserve Venice's memories.

Millionaire Harley Graves (1855-1936) adhered to this vision and actually recreated an artificial "Venice" in Miami. In 1920, he purchased 2.5 square miles of land for development as a tourist resort. He called it "Sunny Isles, the Venice of America."

${ }^{482}$ Marjory Stoneman Douglad, "The Galley. Venice to Miami," The Miami Herald 11, no. 239 (1921, 22 July 1921): 6.

${ }^{483}$ Marjory Stoneman Douglad, "The Galley. Venice to Miami," The Miami Herald 11, no. 239 (1921, 22 July 1921): 6. 
This new suburb presented artificially constructed pointers of Italian/Venetian identity that helped convey stereotypes of what the members of the American high social class in Southeast Florida thought Italy resembled. Palaces over the canals in Venice showed off wealth in the same way as villas and resorts looking over Biscayne Bay did. Attention to details and authenticity were key components in creating 'picturesque' places. In Graves' plans (not fully realized) Sunny Isles included bays, rivers, canals, large hotels, front casinos, a series of islands, and gondolas, all elements that were intended to make Miami picturesque.. $^{484}$

Similarly, in 1921, the creators of Coral Gables (incorporated in 1925) set to establish an area

highly restricted, intelligently zoned, architecturally and landscaping coordinated and controlled, every modern utility, recreational facilities, and hotel accomodations unsurpassed $[\ldots]$. $^{485}$

In order to provide Coral Gables with Mediterranean character, it included beaches and canals where flotillas of iconic flat-bottomed, elegant black vessels (gondolas) transported wealthy visitors and guests from hotels and villas to golf clubs. ${ }^{486}$ In 1925 , George Edgar Merrick, the autocrat who masterminded the development of Coral Gables, purchased another "6000 acres, completing 10000-acre tract to be known as Coral

\footnotetext{
484 "Sunny Isles Property to be the Modern Venice of America Created by the Golden Wand of Millionaire Harvey b. Graves," The Miami Herald 11, no. 272 (1921, 24 August 1921): 8.

${ }^{485}$ Ellen J. Uguccioni, “Coral Gables,” in Miami's Historic Neighborhoods, a History of Community, Becky Matkov Roper (San Antonio: Historical Publishing Network, 2000), 100.

486 “Gondolas Carry Guests to Party at Golf Club," The Miami Herald 11, no. 79 (12 February
} 1921): 7 . 
Gables-Miami Riviera" to build "hundreds of Italian Renaissance, South of France villatype, Italian, Andalucian, Algerian, and Egyptian waterfront villa-type residences." ${ }^{487}$ On this imagined stage, an orientalized Mediterraneanism was showcased in grand style. ${ }^{488}$ Merrick procured Venetian gondolas "with real Italian gondoliers to man them" to infuse

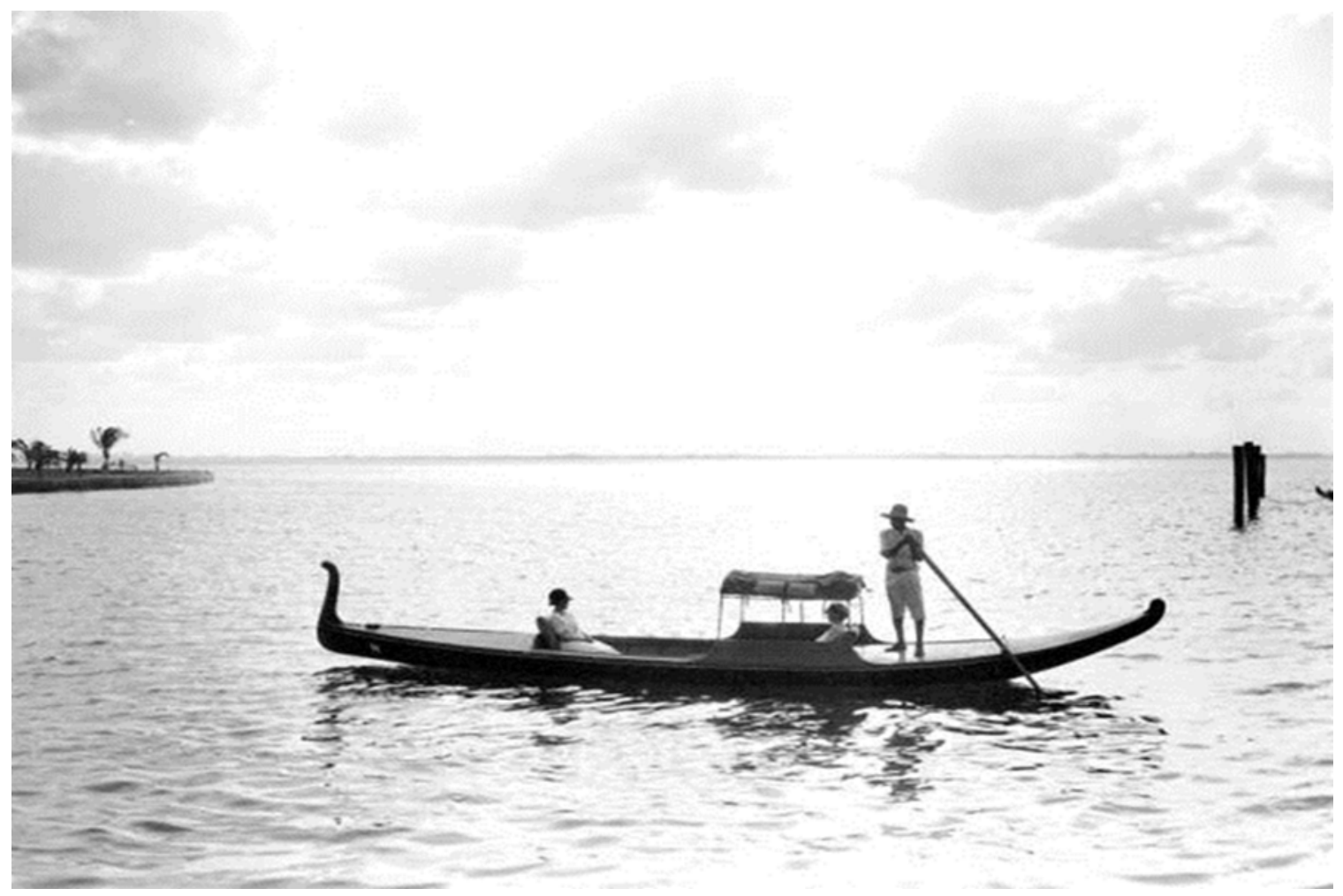

Figure 19. The Gondola. People on a gondola ride - Miami Beach, Florida. Photograph, 1926. Source: State Archives of Florida, Florida Memory, http://floridamemory.com/items/show/42465.

487 “Coral Gables Plans Large Development,” Tampa Tribune, 22 March 1925, 4.

${ }^{488}$ Jonathan Friedlander, "Middle Eastern Americana: Beyond Orientalism," Center for Near Eastern Studies UCLA International Institute University of California, Los Angeles (2009): 363. 
the idea of Italianità that he selected as most appropriate among the many images evoked by the Mediterranean cultures in local popular culture. ${ }^{489}$ Italian gondoliers, however, had entered the scene before Douglas, Graves, and Merrick replicated the Venetian Riviera. They certainly came with a reputation, or contributed to build one in the Caribbean space, if in 1916 the writer of a scientific article in the Miami Herald referred to a water plant growing its stalks below the surface of Caribbean waters as the "gondolier of plants", because as "Venetian lovers do their courting in gondolas - at least so the artists and poets say, $[\ldots]$ one of their compatriots in the plant kingdom does his courting on a raft. ${ }^{490}$ By appropriating Italian elements, those living in Southeast Florida accepted them in everyday life and collective consciousness. ${ }^{491}$ In the mestizo (picturesque pastiche) environment gaining favor in America, the Caribbean came to symbolize for the English-speaking pioneers what the Mediterranean had represented for ancient classical civilizations.

Discussing the rise of Southern California, where entrepreneurs also used the Mediterranean metaphor to attract colonists in the nineteenth and early twentieth centuries, Kevin Starr wrote that the Mediterranean "invoked values of responsible order

\footnotetext{
489 "Latest is "Venetian Waterway' Residence," Omaha World Herald, 24 October 1926, 36. Jonathan Friedlander, "Middle Eastern Americana: Beyond Orientalism," Center for Near Eastern Studies UCLA International Institute University of California, Los Angeles (2009): 363.

490 "Gondolier of Plants," The Miami Herald 6, no. 87 (Febraury 25 1916): 10

${ }^{491}$ Jonathan Friedlander, "Middle Eastern Americana: Beyond Orientalism," Center for Near Eastern Studies UCLA International Institute University of California, Los Angeles (2009): 363.
} 
and conveyed a sense of impending civilization." ${ }^{492}$ This statement applied to Florida as well.

[W]hat the Mediterranean Sea was to the Greeks, breaking the bond of custom, offering new experiences, calling out new institutions and activities, that, and more, the ever retreating frontier has been to the United States directly, and to the nations of Europe more remotely. ${ }^{493}$

Pioneers in this region found "their" Mediterranean in the Caribbean. In the new environment, midwestern and Northeastern businessmen were able to start new institutions and activities and to break the bond of customs established in their home states. These developers recreated the classic elements of civilization that were otherwise missing. All that was Mediterranean could be found in the Caribbean, mild climate included.

Julia Tuttle, once again, was among the first people to appreciate, and to promote, the balmy quality of Miami's weather. In 1886, while she was busy selling her properties in Cleveland to move to Southeast Florida, she wrote to her friend John D. Rockefeller (1839-1937): "I shall need to do something to increase my income somewhat and I have been thinking of getting something to do for a part of the year in a more genial climate. $" 494$ Others followed, again advancing the idea of Florida as the Italy of America.

\footnotetext{
${ }^{492}$ Kevin Starr, Inventing the Dream: California Through the Progressive Era (Oxford: Oxford University Press, 1985), 46..

${ }^{493}$ Frederick Jackson Turner, “The Significance of the Frontier in American History," conference presentation at the 1893 World's Columbian Exposition, American Historical Association (Chicago, 1893).

${ }^{494}$ Tuttle to Rockefeller, December 20, 1886, Record Group 1, Incoming Correspondence, Office
} MS Box 47 (Office, 1879-1894). 
The Official Directory of the City of Miami and Nearby Towns of 1904 opened with a

poem and a reflection.

Knows't thou the land where the lemon tree blows-

Where deep in the bower the gold orange grows?

Where zephyrs from heaven die softly away,

And the laurel and myrtle tree never decay?

Knows't thou it?

Mignon sang thus so sweetly of Italy, 'tis of Florida, the Italy of America, that we sound its praise today, a land where the finger prints of God linger on every flower, and flame in glorious colors on the plumage of the birds; a land where the air is redolent with the perfume of roses and orange blossoms; a land where every living creature rejoices in an existence free from the cankering ills that flesh is heir to. ${ }^{495}$

The author went on with the same elegiac prose for several pages, without mentioning that he had chosen a song in Wilhelm Meister's Apprenticeship book by Wolfgang

Goethe (1749-1832)

Know you the land where lemon blossoms blow, And through dark leaves golden oranges glow, A gentle breeze wafts from an azure sky, The myrtle's still, the laurel three grows highYou know it, yes? Oh there, oh there With you, O my beloved, would I fare. ${ }^{496}$

or the interpretation that British author James Elroy Flecker (1884-1915) had given of it in his poem Mignon

Knowest thou the land where bloom the lemon trees, And darkly gleam the golden oranges?

A gentle wind blows down from that blue sky;

${ }^{495}$ Allan Parrish Reid, Official Directory of the City of Miami, Florida, Including General Information Concerning Churches, Lodges, Societies, City Directory (1904-11), 1.

${ }^{496}$ Goethe, Johann Wolfgang von. Wilhelm Meister's Apprenticeship. Edited and Translated by Eric A. Blackall. (Princeton: Princeton University Press, 1989), 83-84. 
Calm stands the myrtle and the laurel high.

Knowest thou the land? So far and fair!

Thou, whom I love, and I will wander there. ${ }^{497}$

It is symbolic that the author manipulated Goethe's and Flecker's versions to adapt the verse to his intended message; "Deep" replaced "dark" and "darkly", zephyrs came from heaven and not from an azure or blue sky, and the laurel and myrtle not only grew as in Goethe's and Flecker's texts but never decayed.

Italy had a higher visual magnetism than other Mediterranean countries when the discussion revolved around climate. Entrepreneurs, writers, and journalists continued to use the imagery associated with it to capture the attention of their intended audience. In 1915, the headline of the Herald read "Miami's climate better than Naples."498 To support what they thought could be interpreted as a daring assumption, the article continued

Secretary George Paddock, of the Chamber of Commerce, has received from American Consul Jay White, at Naples, a complete report of the climatic conditions there. It shows that Naples has a slight edge on Miami during the summer months, but in the winter - the real tourist season - this city is far in advance of the resort that brings annually 200,000, a great many of whom are Americans. ${ }^{499}$

This piece was crafted for wealthy and educated Americans familiar with travel to Europe. The message ended with "Stay away from Europe when you are looking for ideal

497 James Elroy Flecker, "Mignon," in The Collected Poems of James Elroy Flecker, in The Collected Poems of James Elroy Flecker, J. C. Squire (New York: Doubleday, Page \& Co., 1916), 35.

498 “Miami’s Climate Better Than Naples,” The Miami Herald 5, no. 175 (1915, 24 May 1915): 8.

499 “Miami’s Climate Better Than Naples,” The Miami Herald 5, no. 175 (1915, 24 May 1915): 8. 
climate and stay in America, with the accent on Miami. ${ }^{, 500}$ Miami could be better than Italy, "although minus the legendary atmosphere created by centuries of development" said another article. ${ }^{501}$

Since World War I discouraged Americans from traveling to Europe, Miami’s leading élite tried to gain an advantage by recreating a Caribbean version of Mediterranean Europe. Biscayne Bay was as "blue as the Mediterranean" and was "lined for miles by palatial homes recently constructed. $" 502$ Potential visitors and residents had to know that Miami's harbor had become "the rendez-vous for yachtsmen." ${ }^{, 503}$ It continued to be for many years, because on January 23, 1921, the Miami Herald quoted the department store magnate John Wanamaker's (1838-1922) assessment that "Florida in many respects is the Italy, Spain, and Egypt of the United States [my emphasis]." The Herald ran an editorial on the full page advertisement in a Philadelphia paper paid by "the merchant prince Wanamaker,"as the Herald called him, which reported that the advertisement was “evidently written under Mr. Wanamaker’s direction while he was

\footnotetext{
500 “Miami’s Climate Better Than Naples,” The Miami Herald 5, no. 175 (1915, 24 May 1915): 8.

${ }^{501}$ The Miami Herald 7, no. 38 (1917, 10 January 1917): 4.

${ }^{502}$ The Miami Herald 7, no. 38 (1917, 10 January 1917): 4.

${ }^{503}$ The Miami Herald 7, no. 38 (1917, 10 January 1917): 4.

504 "Wanamaker Advertises Miami’s Charms in Philadelphia Paper," The Miami Herald 11, no. 59 (1921, 23 January 1921): 4. In 1875, John Wanamaker founded the John Wanamaker \& Co. Department Store in Philadelphia, one of the first department stores in the United States and the first one of a chain of John Wanamaker \& Co. department stores. This brand name lasted until 1995, when it was absorbed by Hecht's (present day Macy’s). See Herbert Ershkowitz, John Wanamaker: Philadelphia Merchant (Cambridge: Signpost Biographies, Da Capo Press, 1999).
} 
stopping in Miami on his yacht recently." ${ }^{505}$ In March that same year, the refrain had not changed. Artist Charles Warde Traver (1870-1945) "was so enthusiastic over the wonderful climate $[\ldots]$ that he will build, as soon as possible, on the coast between Indian Creek and the sea, an Italian villa, with a monastery chapel studio where he will work during the winter seasons."

The association of Miami and Southeast Florida with life and vitality that was captured in the pages of the 1904 City Directory continued. It matured in the idea of Miami as a repository of symbols of an Italianità turned into Mediterraneità (among other Mediterranean cultures mimicked in the region) that was admired and marketed by other people besides Miami's early boosters. The "Italian style, feeling, and theme", as headlines defined it, included design, architectural details, and food. It inspired the architecture of many villas, pools, residences, and gardens built up until the 1930s. Not only the Miami Herald, but also leading professional journals of the country devoted articles and photos to these princely projects. ${ }^{507}$ Italian design, merchandise, and food had

\footnotetext{
505 "Wanamaker Advertises Miami’s Charms in Philadelphia Paper," The Miami Herald 11, no. 59 (1921, 23 January 1921): 4.

506 “Traver Plans Italian Villa with Unique Studio on Beach,” The Miami Herald 11, no. 105 (1921, 10 March 1921): 9.

${ }^{507}$ Gordon E. Mayer, “An Italian House at Miami, Florida," American Architect 115 (1919): 8059; "Final Word of Architectural Recognition," The Miami Herald 9, no. 28 (1919, 20 June 1919): 1; "A Beautiful Miami Home. Description of the Charles I. Briggs Residence Nearing Completion at Point View," The Miami Herald 8, no. 342 (1918, 11 November 1918): 2; "Build Balcony Around Pools. Various Improvements at Casino St. John Are Now Under Way," The Miami Herald 11, no. 347 (1921, 7 November 1921): 4; "New Owner of Casino Visions Great Future for Miami Beach," The Miami Herald 11, no. 145 (1921, 19 April 1921): 4; "Renovated Roman Pools for Coming of Season," The Miami Herald 13, no. 7 (1922, 2 December 1922): 3; "Miami Beach Firm Plans More Homes. Two High Class Italian Villas Will be Erected at Early Date," The Miami Herald 12, no. 51 (1922, 15 January 1922): 7.
} 
appealing qualities that even resourceful shop owners transformed and marketed. They advertised in local newspapers their "fine" cut-glass Italian products to keep in mind "when thinking of buying presents," and, since 1920, hotels, restaurants, and grill rooms advertised the "finest" Italian cooking and "special spaghetti dinner." ${ }^{, 508}$ In 1921, Italian cooking further rose in dining classifications. In the restaurant owned by the "pioneer restaurant man of Miami Beach" Leon deLeon, the finest, special Italian cooking became "high class" and was advertised both "table d'hôte and à la carte." ${ }^{\text {"509 }}$ Echoes of Miami's glamor also reached Springfield, Massachussetts, where American traveler and filmmaker Burton Holmes (1870-1958) showcased "Marvelous Moving Pictures [...] to look down upon The Money Mad Rush of Miami!, The Dancing at the Flamingo!, Bathers on the Beach!, The Running Races at Miami!, The Millionaires' Italian Palaces!," in the local auditorium, with tickets ranging from $\$ 0.25$ to $\$ 1.50 .^{510}$ In this as in many other contexts, the 'Italian' villas of Miami's wealthy entrepreneurs were recognized as one of the most representative and picturesque elements of the burgeoning city.

508 "Fine Cut Glass and Italian China," The Miami Herald 1, no. 218 (14 July 1911): 3; "The Finest Dining Room in Miami," The Miami Herald 10, no. 112 (15 March 1920): 4; "Grill Room on Fourth Floor of the New Gallat," The Miami Herald 10, no. 81 (February 13 1920): 8; "Special Spaghetti Dinner," The Miami Herald 10, no. 73 (5 February 1920): 4.

509 "Will Open Miami Restaurant. Leon DeLeon to be Associated with Mrs. Wilson in New Enterprise," The Miami Herald 11, no. 345 (5 November 1921): 4.

510 “Go to Florida with Burton Holmes,” Springfield Republican, 1926, 11 April 1926, 25. 


\section{Caribbean Undertow and Mediterranean Identity}

Anglo settlers' and entrepreneurs' sources of knowledge about Italy and Italians were spotty at best, but their genuine interest in Italian culture asserted itself despite the entanglements of geography and ethnicities. Remarkably, it was school workers who produced a most inaccurate fabrication of Italianità in 1920. The pupils of an Allapattah school in Miami were "gowned in red skirts and bodices, with blouses, Italian peasant head-dress and green scarf" to give an Italian dance during a school parade where children were "costumed in bright colored Gypsy garb." ${ }^{111}$ None of the seventeen dancers was Italian. ${ }^{512}$ Parents, teachers, and the organizers of the parade traded Italian regional costumes - skirts, bodices, and blouses - for gypsies' garbs to be used as costumes to perform gitano dances. For these adults, the exotic fantasy associated with the Spanish Gypsy woman par excellence, Carmen, created by French author Mérimé and opera composer Bizet, belonged to Italy as well. Spain and Italy, two Southern European appendices, had summoned Carmen’s “irrational, mysterious, and childish” qualities in Anglo imagination on the Atlantic side of the Mediterranean. ${ }^{513}$ What Lezama Lima

\footnotetext{
511 "Pupils of Allapattah School to Parade as Gypsies During Fete," The Miami Herald 11, no. 10 (5 December 1920): 6.

512 The article lists the pupils'English names.

${ }^{513}$ Carmen was a novel (1845) by Prosper Mérimé and the name of the protagonist of George Bizet's operatic version (1875) of Mérimé's work. See Aurora Morcillo, "The Orient Within. Women 'inbetween' under Francoism," in Women in the Middle East and North Africa: Agents of Change, Fatima Sadiqi and Moha Ennaji (New York: Routledge, 2011), 262.
} 
called resaca had come ashore, mixed together Italian and Spanish culture, and swept the mélange back out in a picturesque, Caribbean interpretation. ${ }^{514}$

The school example was not isolated; six years earlier, Chicagoan magnate James Deering (1859-1925), who had fallen in love with Spanish culture during his automobile tours of Spain in the early years of the twentieth century, first decided to build a Spanish house in South Florida and then "swept all the Spanish home'plans aside and came to the determination that the building should be of the Italian villa type. ${ }^{, 515}$ In 1912, Deering purchased from pioneer Mary Brickell (1890-1975) 130 acres of land on Brickell Point in Coconut Grove, overlooking Biscayne Bay, to build a "palatial country retreat in fanciful emulation of the European past'. ${ }^{516}$ It took him and his associate Paul Chalfin (18741959) two years to decide on the eclectic technique of displaying art and architectural features that was going to characterize Villa Vizcaya, the construction of which began in 1914. Everything at Vizcaya points to Deering's desire to materialize his idea of civilization in Southeast Florida and to integrate his invention in the Caribbean landscape as if it was indigeneous to the area. In a way, he attempted to ennoble South Florida with an historical past borrowed from the cradle of civilizations, in the Mediterranean. Its name, for example, was apparently preferred to an Italian name in homage to the Spanish

\footnotetext{
${ }^{514}$ Lezama José Lima, Selections, <ed.> Livon-Grosman, Ernesto (Berkley and California: University of California Berkley, 2005), 180.

${ }^{515}$ Witold Rybczynski and Olin Laurie, Vizcaya: An American Villa and Its Makers (Philadelphia: University of Pennsylvania Press, 2007), 21-3.

${ }^{516}$ Witold Rybczynski and Laurie Olin, Vizcaya: An American Villa (Philadelphia: University of Pennsylvania Press, 2007), 5.
} 
Basque province "after which Biscayne Bay is said to have been named."517 "Vizcaya", of Sevillan origin, bound the eclectic Italian-Spanish-French palazzo of European derivation to Florida's history. The blend of so many elements probably offended purist notions of architecture, because on several occasions Chalfin felt that he had to explain Vizcaya. ${ }^{518}$ In 1917, Chalfin clarified that the building was intended to look "as if it had been modified and added to over a long time. ${ }^{, 519}$ In 1934, he went further, and wrote that One might say, then, looking a little beyond the 16th century, that at Vizcaya the architecture of the days of Columbus looks toward the sea; that of Michelangelo looks northward (the 16th), that of Louis XIV toward the garden (the 17th), and that of Madame de Pompadour greets you as you approach through the park. ${ }^{520}$ Deering, a prototype of the powerful and wealthy industrialist of the last quarter of the nineteenth century, "appropriated many of the trappings and social customs of the Old World: horseback riding and foxhunting, shooting, yachting, art collecting, entertaining on a grand scale" to redeem his "parvenu status in comparison to titled Europeans", in the process inventing a 'container' of Mediterranean history and memory. ${ }^{521}$ Robert Hughes

${ }^{517}$ Rybczynski and Olin refer a conversation in 1921 between Chalfin and Arthur Acton (18731953), in which Chalfin confessed that Vizcaya was "almost imposing as the Palazzo Pitti, if you [can imagine the] Pitti standing on a lagoon in Africa." See Witold Rybczynski and Laurie Olin, Vizcaya: An American Villa (Philadelphia: University of Pennsylvania Press, 2007), 56, 54.

${ }^{518}$ Paul Chalfin, "Romance of History in the Language of Art," The Miami Herald, 1934, 23 December 1934.

${ }^{519}$ Quoted in James T. Maher, Twilight of Splendor: Chronicles of the Age of American Palaces (Boston: Little, Brown, 1975), 203.

${ }^{520}$ Witold Rybczynski and Laurie Olin, Vizcaya: An American Villa (Philadelphia: University of Pennsylvania Press, 2007), 27.

${ }^{521}$ Witold Rybczynski and Laurie Olin, Vizcaya: An American Villa (Philadelphia: University of Pennsylvania Press, 2007), 54. 
wrote that the American Italianate style resulted from the conflict between wealthy Americans' belief in their own economic superiority and their cultural insecurity and that, for this reason, they selected and adapted the older civilization, laying claim to it. ${ }^{522}$ Hughes' argument is valid, but it was Deering's and Chalfin's specific choices that were important.

\section{Conclusion}

In the 1890s, when Miami's Tuttle, Flagler, the Brickells, and the Sewell brothers (among others) first arrived to Southeast Florida, they found a wilderness, a river, and the ocean. These men and women were farsighted, however, in imagining and planning a thriving community. Since its inception, Miami and its neighboring areas displayed cultural constructions of what it was to be Mediterranean, and eventually also Italian, for these Anglo entrepreneurs. For them, Italianità was a reinvention of the exotic other that collapsed into Mediterranean identities. Yet, at the beginning, there were no traces of Italians.

An assorted crowd of people from the Northeastern United States soon began arriving in Miami and other parts of the South by means of Flagler's railway. From 1896 to 1939, workers, artists, and laborers filled hotels and villas, camps, and building sites and navigated the canals and waterways of what the far-sighted entrepreneurs were

\footnotetext{
${ }^{522}$ Robert Hughes, American Visions: The Epic History of Art in America (London: The Harvill Press, 1998), 216.
} 
marketing as the American Mediterranean Riviera. Florida became "the American Italy" when specific aspects of an imagined Italianità were deemed necessary to the entrepreneurs' civilizing mission of the South. In the same way, a pastiche of Italian Renaissance, French, and Classical architecture influenced the American Colonial style and became a landmark in the tropical, Caribbean environment. Intellectuals used the term 'picturesque' to identify the peculiar charm deriving from the mélange of old civilization and modern America. "Picturesque" came to represent the modernist outcome of tradition and modernity. ${ }^{523}$ "Picturesque" was the Mediterraneo-Caribbean character of Southeast Florida that made Miami different from other American cities that also displayed elements and interpretations of classical styles. Mediterranean models and Italian culture conveyed a sense of order and impending civilization for Miami's architects, who chose Old-World features as marketing tools to sell property in Florida.

For the élite groups, Southeast Florida, and Miami in particular, represented the gateway between past and present and the place elected to preserve imagined perceptions and memories of the Mediterranean Rivieras. South Florida's prominenti expressed their interest in Italian culture in all its manifestations, even if sometimes they conflated Italianità with Spanishness or Frenchness, transforming it into a hybrid version of Mediterranean identity. The ocean brought ashore Southern European influences that

\footnotetext{
${ }^{523}$ Modernism is different from modernity. I interpret Modernism as the way of seeing images and words as not representing the world the way it is. Modernism shows what is different, or why it is different. For more on Modernism see Walter Benjamin, Illuminations (London: Pimlico, 1999).
} 
South Florida's insular sensibility branded as “Caribbean-Mediterranean." From 1896 to 1939, Southeastern English-speaking developers, entrepreneurs, intellectuals, and members of the middle class - restaurant owners, teachers, school workers, and shopkeepers - satisfied their cultural curiosity by reconstructing Italianità the way they understood it. The few Italians who arrived in Southeast Florida during this period understood it differently, or did not recognize it at all, but as we shall see in the next chapter, they performed their allotted roles. 


\section{CHAPTER 5}

\section{ITALIANS IN MIAMI AND SOUTHEAST FLORIDA: FEW BUT SIGNIFICANT}

Since the early 1800s, American pioneers had pushed the American frontier South, deeper into Florida. After the arrival of a first wave of people predominantly interested in farming, a second wave of entrepreneurs began systematically attempting to 'civilize' the region and one mode of expressing this 'civilization' lay in creating representations of Mediterranean cultures in the Caribbean wilderness. The first two significant buildings in Miami were residences; the third was Flagler's Royal Palm Hotel. ${ }^{524}$ Beginning with the excavation of the Royal Palm's foundations in 1896, hammock and rocky pine lands gave way to solid brick and concrete structures, two- and three-story buildings, ice and cold storage plants, more palatial residences, post offices, schools and a public library, police offices, churches, and banks. ${ }^{525}$ In 1921 , the city had “about 50 miles of paved streets and many more miles of concrete sidewalks", with contracts signed to build lay more. ${ }^{526}$ Miami’s public utilities included telephone, gas,

\footnotetext{
${ }^{524}$ E.V. Blackman, Miami and Dade County, Florida: Its Settlement, Progress and Achievement (Washington: Victor Rainbolt, 1921), 22.

${ }^{525}$ E.V. Blackman, Miami and Dade County, Florida: Its Settlement, Progress and Achievement (Washington: Victor Rainbolt, 1921), 23.

${ }^{526}$ E.V. Blackman, Miami and Dade County, Florida: Its Settlement, Progress and Achievement (Washington: Victor Rainbolt, 1921), 24.
} 
water, and electric light and power. ${ }^{527}$ The Miami Daily Metropolis' first issue appeared May 15, 1896; in 1903, Judge F. B. Stoneman (1857-1941) began the publication of the Miami Evening Record, which became the Miami Herald in 1910. With the growth of Miami and its hinterland, overtly 'cultural' artifacts also proliferated, impacting the landscape, the environment, and the economy. These projects promoted the production of artworks, artisanship, literature, education, and music, activities which were central to the creation of a Mediterranean cultural pastiche that incorporated Italian, French, Spanish, and Moorish idioms and identities.

The economy of culture was a growing sector that required the employment of skilled and educated workers in addition to an unskilled labor force. In 1900, about one hundred years after the arrival of the first pioneers, a third wave of people arrived in Southeast Florida, mainly from Europe. They were immigrants attracted not exclusively by the cheap lands of the frontier, but by the many job opportunities provided by the urbanization of the Caribbean wilderness. The number of people residing in Miami, Lemon City, Coconut Grove, Homestead, and Redland increased in the period 1896-1920 from 502 registered voters to $29,549 .{ }^{528}$ The demand for land first, and for jobs later, advanced the American frontier to its Southernmost point.

${ }^{527}$ E.V. Blackman, Miami and Dade County, Florida: Its Settlement, Progress and Achievement (Washington: Victor Rainbolt, 1921), 24.

${ }^{528}$ United States Federal Census, 1900; 1910; 1920; 1930. 
In the democratic space of the frontier, many inhabitants were of non-English origins. They were mostly resident or transient immigrants who "were Americanized, liberated, and fused into a mixed race, English in neither nationality nor characteristics," and they included Italians. ${ }^{529}$ This process of democratic fusion contributes to an explanation of why Southeast Florida's society was different from that of many areas of the North in the same period. ${ }^{530}$ The new Southern communities included laborers, peons, servants, teachers, artists, police officers, criminals, and aristocrats, with Italians in each category. This chapter shows how these Italians moved in society and interpreted their identity vis à vis the roles that were expected of them according to their hosts' understanding of their Italianità. Such Italianità being only one ingredient of a mixed society that appropriated many other Mediterranean stereotypes.

Elements such as mild climate, food, rivieras, and garbled architectural styles represented what Italianità meant for members of the middle and upper classes of Southeast Florida. ${ }^{531}$ As outlined in the preceding chapter, they used their projections of Italianità for their projects leading to such whimsical sights as Venetian gondoliers

\footnotetext{
${ }^{529}$ Frederick Jackson Turner, "The Significance of the Frontier in American History," conference presentation at the 1893 World's Columbian Exposition, American Historical Association (Chicago, 1893).

${ }^{530}$ See Chapter 3 for a discussion of Harney's theory about the italo-phobia malady. Robert F. Harney, "Italophobia: English Speaking Malady," Studi Emigrazione 22, no. 77 (1985): 6-43.

531 “Miami’s Climate Better Than Naples," The Miami Herald 5, no. 175 (1915, 24 May 1915): 8; "Will Open Miami Restaurant. Leon DeLeon to be Associated with Mrs. Wilson in New Enterprise," The Miami Herald 11, no. 345 (5 November 1921): 4; Susan Braden, The Architecture of Leisure: The Florida Resort Hotels of Henry Flagler and Henry Plant (Gainesville: University Press of Florida, 2002); "Coral Gables Plans Large Development," Tampa Tribune, 22 March 1925, 4;
} 
playing their trade against a pan-Mediterranean backdrop. ${ }^{532}$ In this chapter, further examples of such cultural importation will be revealed, from the engagement of Tyrolean yodelers to perform a Neapolitan repertoire, and the hiring of sculptors Ettore Pellegatta (1881-1940) and Edoardo Camilli (1881-?) to produce busts and caryatids in marble and plaster for Villa Vizcaya, to sending their children to a school named after Italian musician and composer Giuseppe Verdi (183-1901), which offered classes in voice culture, piano instruction, classical and characteristic dancing in French, Spanish, Italian, and English. ${ }^{533}$ In parallel with these invocations of Italianità, they also relied on Italians to build many of the stages on which these 'performances' were to be enacted; for instance, already by 1906, recruiters from the Flagler organization seemed to have clear preconceptions about Italian laborers:

The F.E.C. Railroad is about to dispense with nearly, or all of its colored section hands having made arrangements to get 800 Italians along the line in the near future. Fifty are enroute [sic] now for Eden and other points. The Sycilians [sic] they formerly tried proved too dull, but they have secured a more intelligent set of men now. The colored man seems rather too independent for that class of work which requires a man to be constantly on the job...but the Dago can be counted on the day after pay day as certainly as at any other time; though it is admitted he will not do as much work in a given time as a black man, but will achieve more in time, owing to his presence at all times [my emphasis]. ${ }^{534}$

\footnotetext{
532 "Gondolas Carry Guests to Party at Golf Club," The Miami Herald 11, no. 79 (12 February 1921): 7; "Concert Tonight Will Offer Varied Music. American and Italian Selections Will be Given in Miami Beach Church,” The Miami Herald 13, no. 20 (1922, 15 December 1922): 8.

533 "Verdi School of Opera and Oratorio," The Miami Herald 8, no. 341 (1918, 10 November 1918): 3;

${ }^{534}$ Quoted in Marvin Dunn, Black Miami in the Twentieth Century (Gainesville: University Press of Florida, 1997), 63.
} 
In the absence of systematic data concerning the numbers and affiliations of Italians in this period of Miami's history, considering the individual biographies of the few who left clear traces in the historical record is crucial to establish the general outlines of the social field that they could potentially occupy. While we cannot argue that these individuals were representative of the Italian community as a whole, we cannot dismiss them a priori as isolated examples; the fact that Italians played a particular role in the developing cultural and economic stage of Southeast Florida, regardless of the potentially idiosyncratic route that led them to it, establishes that such roles were at least theoretically open to others with a comparable background and resources. The following pages present the available data on the range of roles available to Italians in the early history of Miami.

\section{The Laborers}

Chapter 3 examined how, by the 1880 s, migrants had become a topic to address and a problem to solve for both the US and Italian governments. Following the 1885 United States Alien Contract Labor Law, which prohibited the importation and migration of foreigners and aliens under contract or agreement to perform labor in the United States, in 1888 the Italian government passed the first Italian law on emigration to regulate private agents' recruitment activities and to prevent abuse of emigrants. This legislation represented an effort to crush the "padrone system". 535

\footnotetext{
${ }^{535}$ For Gabaccia, padroni were middlemen who sometimes financed trips of labor migrants across the seas, they were "labor agents who exacted a commission from their clients. They sold jobs to men
} 
Nevertheless, only in 1901 did the Italian government constitute a Commissariat of Emigration to organize an ordered exodus of its people. ${ }^{536}$ The Commissariat, also responsible for setting up two sets of emigration statistics (one for the North and one for the South), provided health inspection and other controls at ports of embarkation (Palermo, Naples, and Genoa). In addition, it also organized assistance to immigrants upon their arrival in the countries of destination and regulated their remittances, which made up a considerable proportion of the Italian national product. ${ }^{537}$ The 1910 US census tallied a mere eighteen Italians in Dade County. This figure increased to 128 in 1920 and 271 in 1930, so the number of Italians or Americans of Italian descent living in South Florida remained tiny, compared to the sizable communities then existing in the Northeast or Midwest. For instance, the 1912 Bollettino dell'Emigrazione reports that, among the over two million Italians who lived in North America at the time, some 500,000 resided in New York, 100,000 in Chicago, 80,000 in Philadelphia, and 50,000 in Boston. The number of Italians residing in South Florida would remain small even if it included the many young men who filled the shacks of Dade County building sites or the

eager to migrate." See Donna Gabaccia, Italy's Many Diasporas (Seattle: University of Washington Press, 2000) 64-5. Feb. 1885: 3 .

536 "National Capital Topics. The Foreign Contract Labor Bill Passed," The New York Times, 19

${ }^{537}$ Elizabeth Cometti, “Trends in Italian Emigration,” The Western Political Quarterly 11, no. 4 (1958): 820-34. For Italian remittances: Dino Cinel, The National Integration of Italian Return Migration: 1870-1929 (New York: Cambridge University Press, 1991) 141-3; Leonard H. Covello, The Social Background of the Italo-American School Child (Leiden, Netherlands: E. J. Brill, 1967), 29. 
out-of-the-way FEC camps strung out along the Florida Keys, who remained uncounted. $^{538}$

Overlooked by their own government and by that of the United States, these Italian migrants have left faint traces in the historical record. Understanding what these few individuals did or thought and juxtaposing this with the feelings, opinions, and attitudes about Italianità of their contemporaries living in Miami and Southeast Florida (found in letters, articles, sketches, surveys, advertisements, and other data in public and private archives) can help clarify how these different social groups formed their identity and how they acted within their community and their new nation. Studying the actions of this small group of Italians tells us if they changed the way they saw themselves according to the image others had of them or if they influenced the perception of their host community. They might have been small in number, but they moved in what the English-speaking boosters considered an ideal space to replicate Mediterranean cultures.

Flagler, his architects, surveyors, and planners left it to their agents to think about Italians. What concerned them was Italy's past grandeur, not its present state or its people. And when agents thought of Italians, it meant that they needed workforce or a hint of exoticism for their tourist industry. Historian George Pozzetta wrote that Miami's boom, and in particular the railroad construction in South Florida, induced FEC agents, and in some cases the same railroad employers, to tour the urban centers of the

\footnotetext{
${ }^{538} 1910$ Manuscript Census, Miami Dade County, microfilm, Miami-Dade Main Library; 1920 Manuscript Census, Miami Dade County, microfilm, Miami-Dade Main Library; 1930 Manuscript Census, Miami Dade County, microfilm, Miami-Dade Main Library.
} 
Northeastern U.S. in search of laborers among the recently-arrived immigrants, who in this period were mostly Italians and Greeks. ${ }^{539}$ The East Coast Railroad "hired" many of them, as the announcements in the Miami Metropolis confirm: "A car load of Italians from the north is expected here daily for works on the keys [sic] on the railroad extension"; "A large number of Greeks arrived here yesterday and proceeded to Homestead where they will work on the extension"; and "It is the intention of the F.E.C. Railway Company to secure and work as many of these men as possible and other and larger numbers of them will arrive in a few days."

The recruitment practices were unorthodox, and eventually led to peonage. The Italian government ordered the Commissariat of Emigration to conduct an investigation on peonage when word reached Rome that Italian emigrants were among its victims. In 1910, Commissioner of Emigration Count Girolamo Moroni sent a report to the Italian government titled "Peonage in the Southern states of the United States". ${ }^{541}$ Moroni

\footnotetext{
${ }^{539}$ Raymond Mohl and George Pozzetta, From Migration to Multiculturalism: A History of
} Florida Immigration, The new history of Florida, Michael Gannon (Gainesville: University Press of Florida, 1996).

${ }^{540}$ Jerry Wilkinson, compiler. Krome Collection. Building the Overseas Railroad: Newspaper Clippings October 1905 to December 1906, preserved by William J. Krome and the Krome Family. Tavernier: Jerry Wilkinson, 1995. Volume 1905-06. See July 16, 1906. pg. 105; August 11, 1906. pg. 115; and August 15, 1906. pg. 118. Quoted in Joe Knetsch, "The Peonage Controversy and the Florida East Coast Railway," in Tequesta (Miami: Historical Association of Southern Florida, University of Miami, 1997) 9. Joe Knetsch writes that one of the main sources for his article is Wilkinson's compilation of newspapers clippings (probably all from Miami Metropolis) from October 1905 to December 1906, the Krome Collection.

${ }^{541}$ Cordasco Francesco and Vaughn Cordasco Michael, The Italian Emigration to the United States, 1880-1930: A Bibliographical Register of Italian Views Including Selected Numbers from the Italian Commissariat of Emigration, Bollettino Dell'Emigrazione (Fairview, N. J.: Junius-Vaughn Press, Inc., 1990) 96-114. 
presented an analysis of what he termed a 'crime' [peonage], providing a definition of the term, case studies involving Italians, explanations for the causes of peonage in the Southern US, and a list of US federal and state laws dealing with this offense. Moroni explained that "The crime of peonage is to oblige a person to a service in order to repay an alleged or real debt in whole or in part." ${ }^{542}$ Peonage was the response of at least six former slave-holding Southern states to the abolition of slavery in 1865, but the 1867 federal Peonage Abolition Act declared peonage unlawful. Florida, Georgia, Mississippi, Alabama, New Mexico, and Louisiana challenged the Act with local statutes, which federal judges addressed case-by-case and declared illegal. ${ }^{543}$ In his report, Moroni wrote that also in the case of Florida, federal Judge James W. Locke had declared that forcibly inducing men to involuntary work under the threat of arrest or legal proceeding was considered peonage. ${ }^{544}$ But as federal law collided with local habits, corrupt sheriffs and local judges often sided with entrepreneurs to enact a practice that resembled slavery.

\footnotetext{
${ }^{542}$ Cordasco Francesco and Vaughn Cordasco Michael, The Italian Emigration to the United States, 1880-1930: A Bibliographical Register of Italian Views Including Selected Numbers from the Italian Commissariat of Emigration, Bollettino Dell'Emigrazione (Fairview, N. J.: Junius-Vaughn Press, Inc., 1990) 97.

${ }^{543}$ Don E. Fehrenbacher and Ward M. McAfee, The Slaveholding Republic: An Account of the United States' Government Relations to Slavery (Oxford: Oxford University Press, 2001).

${ }^{544}$ Moroni wrote: "Il reato di peonage consiste nell'obbligare una persona ad un servizio a favore di un'altra, col pretesto nel più dei casi, ch'essa debba estinguere, in tutto o in parte, un suo debito, preteso o reale." See Cordasco Francesco and Vaughn Cordasco Michael, The Italian Emigration to the United States, 1880-1930: A Bibliographical Register of Italian Views Including Selected Numbers from the Italian Commissariat of Emigration, Bollettino Dell'Emigrazione (Fairview, N. J.: Junius-Vaughn Press, Inc., 1990) 97.
} 
My translation of Moroni's 1910 testimony on peonage practices directed against Italians working for Flagler offers new information for the understanding of the railroad construction to Key West. It brings to light facts about the "hundreds" of Italians who worked under poor conditions. Even if tiny, these numbers add new evidence to the historical record. Their treatment rendered Italians as 'unnamed extras' - vital to the project, but always marginalized. They were lumped together with other Southern Europeans and Northern African individuals.

Peonage in Florida - In December 1906, a legal action was taken against the East Coast Florida R.R. Co., owned by the millionaire Flagler of New York. The East Coast Florida Railway Co. hired laborers to construct the Key West extension of its railway. The railway tract under construction is 153 miles long, 50 of which on land and the remaining on palafittes; it crosses the Keys Islands, united by bridges, some of which up to 5 miles long. The rocky and sandy islands have sparse tropical foliage; water is not potable; their land is covered by swamps infested by mosquitoes. Flagler's East Coast Florida R.R. is directed by Mr. Meredith, an engineer residing in Miami; its inspector is Mr. Krome, who also supervises building sites and work fields (campi di lavoro). These camps are scattered right and left of the railroad under construction, and each camp has its own engineer, 'foremen', and 'bosses' [in English in Moroni's text]. When bridges had not yet been constructed, the company provided a 'steam-boat service' to connect the work fields. Before October 1907, many Italians were employed in the construction of the railroad, but when I visited the camps, there were no more Italians to be found. ${ }^{545}$

In this tropical outpost

between 1905 and 1907, the Agency Frank Sabbia of New York and Mr. Triai, an agent of Jacksonville, Florida, recruited and sent hundreds of Italians to work for Flagler in the Florida Keys. They enticed the laborers, with the promise of an earthily heaven rich with fruit, tropical lush, and ideal climate, to a harsh work in

\footnotetext{
${ }^{545}$ Moroni in Cordasco Francesco and Vaughn Cordasco Michael, The Italian Emigration to the United States, 1880-1930: A Bibliographical Register of Italian Views Including Selected Numbers from the Italian Commissariat of Emigration, Bollettino Dell'Emigrazione (Fairview, N. J.: Junius-Vaughn Press, Inc., 1990) 99.
} 
swamps infested by mosquitoes, under tropical heat and with scarcity of water. Before the legal suit in New York, our people were subject to inhuman treatment, exploited on the job and embezzled of their miserable compensation, because food provisioning was provided exclusively by the East Coast Railroad at very high prices. ${ }^{546}$

Flagler's agents understood what Italian laborers expected from America and lured them

to find it in Florida, "the Italy of America." 547 Even if used to a history of subjugation to

foreign powers in Italy, Italians, however, had yet to experience the captive conditions

imposed by Flagler's foremen:

Since labor camps were located on small keys (isolotti) with no connection to land, our people were not able to leave and were consequently forced to remain in involuntary servitude. Some were able to escape, to reach Miami and from there to travel north; but most of those who escaped were captured in Miami and, following the East Coast Florida Co.'s orders, arrested and condemned for vagrancy and led back to work in the Keys. A federal investigation has led to the prosecution of Meredith and Krome, accused of 'peonage' as per Section 5526 of the Revised Status, while Frank Sabbia and his agent in Jacksonville have been prosecuted based on Section 5525 of the same law. As of now, I believe that the process has not yet concluded. ${ }^{548}$

By analyzing numerous newspaper clippings from the collection of FEC engineer William J. Krome (1876-1929), it is possible to shed light on the recruitment system that Sabbia and Triai used to staff Flagler's project in the Keys. One of these clippings, from

\footnotetext{
${ }^{546}$ Cordasco Francesco and Vaughn Cordasco Michael, The Italian Emigration to the United States, 1880-1930: A Bibliographical Register of Italian Views Including Selected Numbers from the Italian Commissariat of Emigration, Bollettino Dell'Emigrazione (Fairview, N. J.: Junius-Vaughn Press, Inc., 1990) 99.

${ }^{547}$ Allan Parrish Reid, Official Directory of the City of Miami, Florida, Including General Information Concerning Churches, Lodges, Societies, City Directory (1904-11), 1.

${ }^{548}$ My translation. Cordasco Francesco and Vaughn Cordasco Michael, The Italian Emigration to the United States, 1880-1930: A Bibliographical Register of Italian Views Including Selected Numbers from the Italian Commissariat of Emigration, Bollettino Dell'Emigrazione (Fairview, N. J.: Junius-Vaughn Press, Inc., 1990) 99.
} 
the Brooklyn Eagle Report in January, 1906, records an interview with E. J. Triay’s

(Moroni's 'Mr. Triai') in which he outlined the terms of the contract that laborers signed

before leaving the principal centers of recruitment in the Northeast

Due Florida East Coast Railroad $\$ 12$ for value received, And I hereby authorize said railway company, should said railway company at any time to become indebted to me at any time before payment hereof to apply hereon any amount or amounts for part or parts thereof so due me as same may become due and payable. The said Railway company to pay $\$ 1.25$ per day without board. ${ }^{549}$

Triay explained that the company furnished "free" transportation from Jacksonville to Miami, but that the $\$ 12$ fare from New York to Jacksonville had to be paid by the men and that "this is not only implied by the contract, which is short and plainly printed, but it is also explained in a circular printed in English on one side and Italian on the other." The agent continued, "the men are housed free by the company in comfortable quarters; they buy their own food, sold at the commissary department at reasonable prices, and can live well on $\$ 2.50$ per week." 550 With a pay of $\$ 1.25$ per day and an expense of $\$ 2.50$ per

\footnotetext{
${ }^{549}$ Jerry Wilkinson, compiler. Building the Overseas Railroad: Newspaper Clippings October 1905 to December 1906, Preserved by William J. Krome and the Krome Family. Tavernier: Jerry Wilkinson, 1995. Article entitled: Condition on the Keys Told by Mr. Triay. Quoted in Joe Knetsch, "The Peonage Controversy and the Florida East Coast Railway," in Tequesta (Miami: Historical Association of Southern Florida, University of Miami, 1997) 7. Knetsch explains that the Triay article was sent to J. P. Beckwith, of the FEC, who passed it on to Mr. Flagler. The article was dated January 5, 1906, and is attached to some of the Brooklyn Daily Eagle stationary, and can be seen at the St. Augustine Historical Society, "Florida East Coast Railroad" files, Me 13, Box 1, Folder 20, St. Augustine, Florida.

${ }^{550}$ Jerry Wilkinson, compiler. Building the Overseas Railroad: Newspaper Clippings October 1905 to December 1906, Preserved by William J. Krome and the Krome Family. Tavernier: Jerry Wilkinson, 1995. Article entitled: Condition on the Keys Told by Mr. Triay. Quoted in Joe Knetsch, "The Peonage Controversy and the Florida East Coast Railway," in Tequesta (Miami: Historical Association of Southern Florida, University of Miami, 1997) 7. Knetsch explains that the Triay article was sent to J. P. Beckwith, of the FEC, who passed it on to Mr. Flagler. The article was dated January 5, 1906, and is attached to some of the Brooklyn Daily Eagle stationary, and can be seen at the St. Augustine Historical Society, "Florida East Coast Railroad" files, Me 13, Box 1, Folder 20, St. Augustine, Florida.
} 
week, laborers were duped to believe that the $\$ 12$ transportation charge could be reimbursed in about three months; the prospect of a decent profit convinced them to sign the contract and to leave for Miami. Instead, given the inflated prices of food, which Moroni also recorded, the men could not easily repay their debt, and in fact this was likely to increase. As the Brooklyn Eagle article reported: "without a personal mode of transportation to the mainland, a worker was at the mercy of the company and its supervisors. ${ }^{.551}$ This observation confirmed Moroni's testimony, indicating that Flagler's agents forced Italians seeking work on the railroad into peonage.

The fact that a few laborers escaped FEC Railway Co.'s lunga mano and managed to return to New York, where some denounced their experiences to Commissioner of Licenses John N. Bogart (1879-1941), demonstrates their determination to speak out in spite of their status. ${ }^{552}$ The laborers were young and in pitiable condition, but Bogart believed their accounts and began an investigation. He discovered what Moroni would also expose in 1910 - that the FEC Railway enslaved workers through debts by contracting men to reimburse their transportation charges to Miami at an exorbitant physical and financial expense.

Bogart unmasked the viciousness of a system that severely debilitated individuals, often rendering them physically unable to work. They had no alternative: leaving the FEC

\footnotetext{
${ }^{551}$ Joe Knetsch, "The Peonage Controversy and the Florida East Coast Railway," in Tequesta (Miami: Historical Association of Southern Florida, University of Miami, 1997) 6-7.

552 Gordon N. Carper, "Peonage in the South,” Phylon 37, no. 1 (1976): 85-99.
} 
camps involved a high degree of risk, because workmen were subject to arrest under Florida's laws regulating debt. Sheriffs either convicted fugitives to serve time in a convict-lease system, or returned them to the foremen and bosses in the construction camps to clear their debts. So cruel were the working conditions in Flagler's construction sites that many preferred to serve time in the convict-lease system. ${ }^{53}$ The records of their escape attempts and complaints to American and Italian authorities are all that are left of the voices of these laborers in this part of the Atlantic.

The idea of Italian immigrants coming up against the US justice system is significant. Slavery charges were imputed to the railroad's officers and Henry Flagler indirectly. The trial against Flagler's agents-David E. Harley, Francesco Sabbia, Edward J. Triay, and Frank A. Huff — took place in November 1908, but the Judge, Charles M. Hough of the United States Circuit Court, issued a verdict of not guilty. Mr. Hough argued that peonage was not the same as slavery, and since the prosecutors had charged Flagler's agents with slavery, they had to be released. The use of a more pertinent word would have possibly changed the verdict. ${ }^{554}$ Obviously, the trial had repercussions among the East Coast Railway's Italian laborers, because Moroni concluded that when he inspected the labor camps 'there were no more Italians to be

${ }^{553}$ Gordon N. Carper, "Peonage in the South,” Phylon 37, no. 1 (1976): 91.

554 Joe Knetsch, "The Peonage Controversy and the Florida East Coast Railway," in Tequesta (Miami: Historical Association of Southern Florida, University of Miami, 1997) 22. 
found. ${ }^{555}$ It seems likely that the Florida East Coast Company's Italian workers had returned north to Miami, where they found employment in construction projects that coincided with the development of Miami and the growth of the surrounding neighborhoods. Here, they faced different perceptions and expectations of Italianità.

There were certainly more Italians in the region than the number suggested by official figures. Census data illustrate the growth of Southeast Florida's population from 1900 to $1930 .{ }^{556}$ The number of people residing in Miami and in the communities of Lemon City and Coconut Grove grew from 502 registered voters in 1896 to 1,681 in 1900, 5,471 in 1910 (18 of whom were Italian), and 29,549 in 1920 (128 Italians); by 1930, the number of Italians had more than doubled to 271 . Aside from the official records, we know that in 1906 the F.E.C. Railroad had made arrangements to hire 800 Italians, fifty of whom were already en route ${ }^{557}$ After Miami, Homestead and Redland had the highest density of Italian residents in 1920, who were attracted by the construction of the Florida East Coast Railway extension from Miami to Key West

\footnotetext{
${ }^{555}$ Cordasco Francesco and Vaughn Cordasco Michael, The Italian Emigration to the United States, 1880-1930: A Bibliographical Register of Italian Views Including Selected Numbers from the Italian Commissariat of Emigration, Bollettino Dell'Emigrazione (Fairview, N. J.: Junius-Vaughn Press, Inc., 1990) 99.

${ }^{556}$ Lemon City was a small community in the early 1900s. It got its name from the numerous lemon trees that grew in the area. Apart from a 'railway warehouse' along the Florida East Coast Railroad, the community had nothing that resembled a city. In 1925, Miami grew to incorporate Lemon City, Little River to the North, and Buena Vista to the south. See Thelma Peters, Lemon City: Pioneering on Biscayne Bay, 1850-1925 (Miami: Banyan Books, Inc.). For Coconut Grove, see: Livingston, Grant. "The Annexation of the City of Coconut Grove." Tequesta, the Journal of the Historical Association of Southern Florida LX (2000): 32-55.

${ }^{557}$ Quoted in Marvin Dunn, Black Miami in the Twentieth Century (Gainesville: University Press of Florida, 1997), 63.
} 
(1905-12). ${ }^{558}$ Homesteaders reached the territory adjacent to Flagler's railway, where they joined the workers camped along the line. A 1901 letter from V. Palumbo, an Italian labor agent in New York, to the general superintendent of the Florida East Coast Railway discussed his plans for the sale of land in Miami to potential Italian buyers

I would start advertising in the Italian Papers for men, stating the conditions, copy of which I sent you at once. In the advertisement, I stated that he who desired to go to Florida was to purchase an acre of land, costing from $\$ 25$ to $\$$ 30 per acres, paying five dollars in cash before leaving, and the balance in monthly rates of $\$ 2.00$ each, to be paid into the hands of the company until fully paid. In answer to this ad, I received over 300 letters: and 23 men were ready to leave on January $24^{\text {th }} 1902 .{ }^{559}$

Italians not only participated in the construction of Flagler's railway extension. This letter indicates that they could also be property owners. ${ }^{560}$

On one hand, pioneers were busy constructing Southeastern Florida with suggestive elements of Italianità; on the other, there was the reality of everyday Italian folk, many of whom were working people conversing in their own language, with their own conceptions of Italianità and confronted by the preconceptions of others. A joke

\footnotetext{
${ }^{558}$ United States Federal Census, 1900; 1910; 1920; 1930.

${ }^{559}$ In English in the text. Quoted in George Pozzetta, "A Padrone Looks at Florida: Labor
} Recruiting and the Florida East Coast Railway," Florida Historical Quarterly 54 (1975): 81. See also Jean Taylor, The Villages of South Dade (St. Petersburg: Byron Kennedy and Company, 1986) 157. Homestead's own name originates from the Homestead Act, the 1862 federal law that gave applicants full property of acres of undeveloped land. The Italians residing in Florida [City] were first recorded in 1930, with a peak of eleven individuals.

${ }^{560}$ However, those of them who lived in Homestead and Redland until 1920 relocated, because the 1930 census shows that in that year, Homestead and Redland had fewer Italian occupants, whose names did not correspond to the ones in the 1920 . 
circulated in 1911 in which two women (Mrs. McClaugh and Mrs. McGooghan)

conversed on the school progress of Mrs. McGooghan's son

Mrs. McClaugh-Is your son goin' to school now, Mrs. McGooghan?

Mrs. McGooghan - No, sure he's t'rew wid the English branches.

He's perfectin' his Italian now."

"Where?"

"Helpin' dig a sewer down on the road beyant." ${ }^{561}$

The vignette suggests that spoken Italian must have been fairly common in Miami by 1911 and that Italian speakers were often far removed from the grand hotels and palaces of the growing city.

According to the 1910 census, eighteen native speakers officially resided in Miami. ${ }^{562}$ How could eighteen individuals shape the community's imaginary sphere, and become lore? It scarcely seems credible and it may be that there were many more Italians in the area than the Census reveals. Comparing the number of Italians residing in Miami and its adjoining centers according to the 1910 census with those listed in the 1904-1911

561 “Perfecting His Italian,” The Miami Herald 1, no. 256 (1911, 21 August 1911): 3.

${ }^{562}$ Of these 18 individuals, 3 lived in Lemon City; 3 in Fulford; 1 in Allapattah; 6 in Miami proper; 3 in Hallandale; and 2 in North Miami. United States Federal Census, 1900; 1910; 1920; 1930. Captain William H. Fulford gave his name to the community existing in present day North Miami Beach in 1926. In 1927 Fulford was incorporated, but in 1931 became part of Miami with the name of North Miami Beach. Allapattah, "alligator" in the Seminole language, bordered the Northwestern part of Miami. The Seminole Indians occasionally lived in Hallandale Beach, where they gathered roots and hunted. Hallandale is named after Luther Halland, who built a trading post in the area, and eventually became its first postmaster. It was incorporated in 1927. See: Helen Muir, Miami, U.S.A. (Gainesville: University Press of Florida, 1953). 
city directories also confirms that many Italians living in the region were not recorded systematically. ${ }^{563}$ The latter documents include the names of 122 Italians, nearly seven

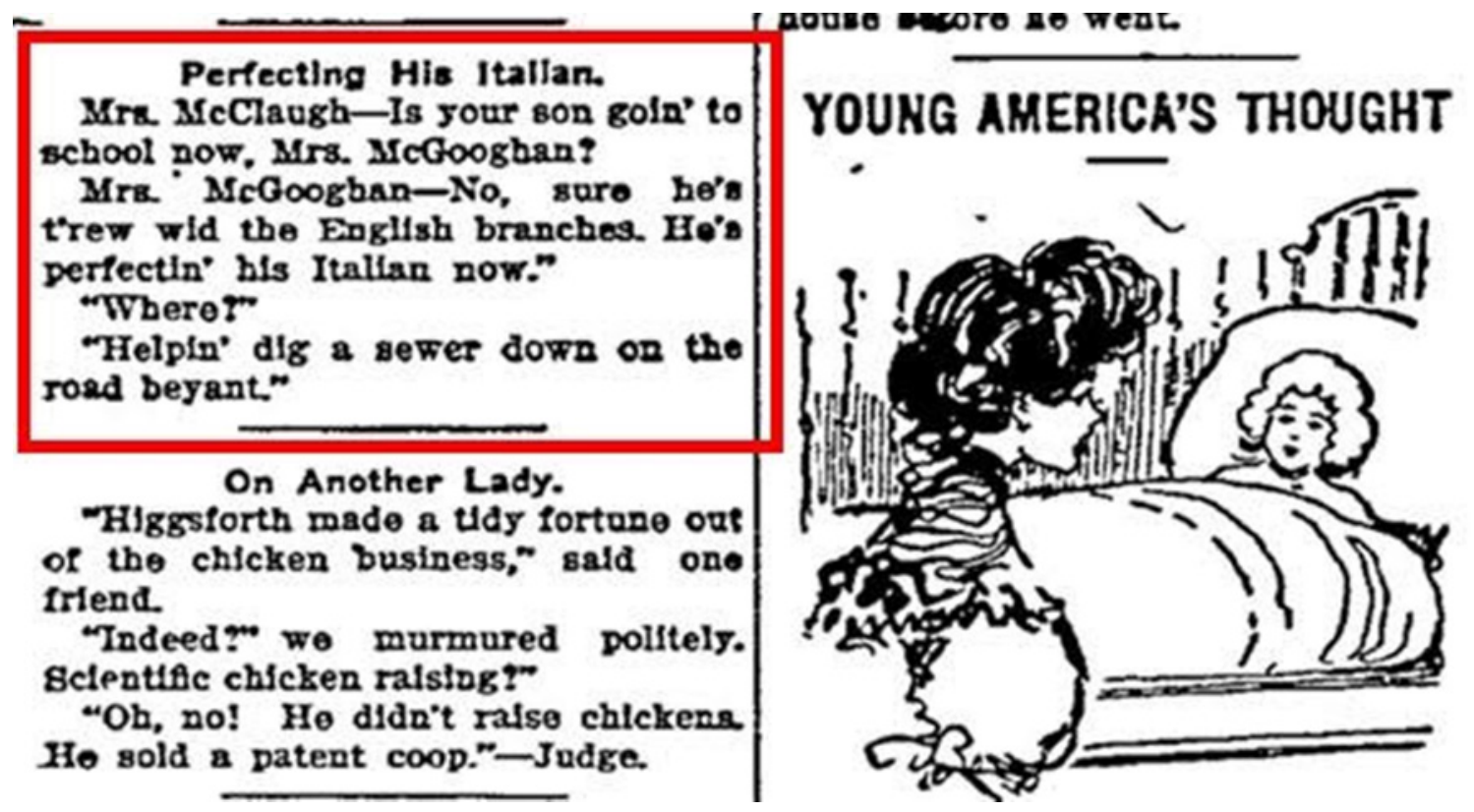

Figure 20. Perfecting His Italian. Source: "Perfecting His Italian,” The Miami Herald 1, no. 256 (1911, 21 August 1911): 3.

times as many as those recorded in the census for the same period (eighteen).

Considering that data from the 1906, 1909, and 1910 city directories are not available,

this disparity is likely an underestimation. Of the eighteen Italians in the census, only two are also listed in the city directories: John Musumeci and Johnnie Varallo. The 1908 city directory indicates a "Musumeci post card store" located at 222, $12^{\text {th }}$ in Miami, and that a John Varalle [sic] managed a fruit store at 721 Av. D. ${ }^{564}$ The discrepancy between the

\footnotetext{
563 The Miami city directories included data from Miami proper and Fulford, Lemon City, Hallandale, Allapattah, and North Miami.

${ }^{564}$ Allan Reid Parrish, Official Directory of the City of Miami, Florida, Including General Information Concerning Churches, Lodges, Societies (Miami: City of Miami, c. 1904; 1905; 1907;1908; 1911). United States Federal Census, 1910; 1920; 1930.
} 
census data and city directories is not surprising, considering, for instance, that Moroni had reported that agents Frank Sabbia and Triay had recruited and sent hundreds of Italians to work for Flagler in the Florida Keys. ${ }^{565}$

In order to understand how these Italian laborers acted and were treated outside of Flagler's camps, it would be interesting to examine pertinent judicial disputes, arrest records, and similar documents. In this region, however, there are no official records of accusations, clashes, and violence towards or between different ethnic immigrant groups. ${ }^{566}$ Nevertheless, the details of a crime perpetrated in 1916 provide information on the area of the city where Italians seem to have lived. An Italian, Tony Delbia, was locked up on a "serious charge":

Tony Delbia, an Italian about forty-five years old, was arrested by Deputy Sheriff Harry Morris yesterday on a serious charge preferred [sic] by the father of a seven-year-old Italian girl. The alleged offence occurred near the child's parents home in the northwestern section of the city Saturday afternoon. Delbia was locked up in the county jail. ${ }^{567}$

Although the text is silent on the details of his offence, nonetheless it presents important information. The fact that at least some Italians lived in Colored Town, the Northwestern quadrant of Avenue $\mathrm{H}$, suggests that neither country or birth nor race predetermined absolutely the dynamics of settlement by immigrants in Southeast Florida, in contrast to

\footnotetext{
${ }^{565}$ Cordasco Francesco and Vaughn Cordasco Michael, The Italian Emigration to the United States, 1880-1930: A Bibliographical Register of Italian Views Including Selected Numbers from the Italian Commissariat of Emigration, Bollettino Dell'Emigrazione (Fairview, N. J.: Junius-Vaughn Press, Inc., 1990) 96-114. 1997), 101.

${ }^{566}$ Marvin Dunn, Black Miami in the Twentieth Century (Gainesville: University Press of Florida, 567 “Locked up on a Serious Charge,” The Miami Herald 7, no. 2 (1916, 4 December 1916): 3.
} 
Northeastern states. ${ }^{568}$ In this region, they seem to have set up their homes according to their economic and social status rather than by clustering among their compatriots.

\section{New Courtiers and Aristocrats}

Miami was a stage ready for wealthy visitors. The Royal Palm Hotel's guests included notables from all over the world, including "a number of European royalty, mostly in incognito, [and] great statesmen and great financiers". ${ }^{569}$ One of these incognito personalities was Prince Louis Amadeus of Savoy, Duke of Abruzzi (1873-1933) and a grandson of King Victor Emmanuel II of Italy. He is remembered for his scientific expeditions, particularly his 1899 Arctic exploration, but he was also a vice-admiral in the Regia Marina (the Italian Royal Navy); in 1907, he visited the United States in this capacity. On this occasion, he attended the Jamestown Exposition organized to celebrate the tercentennial anniversary of the birth of the United States. ${ }^{570}$ Sometime later, he must have traveled further south, because a title in the first page of The Miami Metropolis' issue of January 19, 1909 reported "Duke of Abruzzi now in Miami. Fiancé of Miss Katherine Elkins.” The article provided more details:

He is traveling incognito. Few know of his presence. It will be remembered that he and Miss Elkins visited Miami last season, but their presence here was unknown until after they had made their departure. All Rome [is] anxious to know

\footnotetext{
${ }^{568}$ John Sewell, Memoirs and History of Miami, Florida (Miami: The Franklin Press, Inc., 1933), 172.

${ }^{569}$ John Sewell, Memoirs and History of Miami, Florida (Miami: The Franklin Press, Inc., 1933), 199-205.

570 “Katherine Elkins Divorced from Hitt," The New York Times, 1922, 12 January 1922.
} 
the whereabouts of the Duke. [...] Mrs. Elkins, mother of Miss Katherine Elkins was here during the entire season, but the presence of the Duke and Miss Elkins and their three friends was never known except by Mrs. Elkins and their immediate family. ${ }^{571}$

Louis Amadeus of Savoy, heir to the throne of Italy, was in Miami for two years in a row, in 1908 and 1909, traveling incognito and in the company of the American heiress Katherine Elkins (1886-1936). ${ }^{572}$ Italian and American newspapers speculated extensively on the relationship between the prince and the commoner and on the obstacles created by their different ranks and religions (Louis Amadeus was Roman Catholic and Katherine was Protestant), which eventually led to their separation. This sort of romance undoubtedly excited Miamians, because in the same period the Miami Herald reported the news of the wedding of Miss Marguerite Gilbert Chapin (1880-1963), daughter of Lindley Hoffman Chapin (1854-1896), of New York, and Roffredo Caetani (1871-1961), Prince of Bassiano and second son of the Duke of Sermoneta of Italy (1842-1917), which took place in London. ${ }^{573}$

It was in part through such stories that Americans in Southeast Florida infused a touch of the Mediterranean within their Caribbean settlement, "European germs"

\footnotetext{
571 "Duke of Abruzzi Now in Miami. Fiancé of Miss Katherine Elkins," The Miami Metropolis 6, no. 22 (1909, 19 January 1909).

${ }^{572}$ Louis Amedeus was cousin to the King Victor Emmanuel III (1869-1947), who had no direct descendants. Katherine Elkins' father was Senator Stephen B. Elkins of West Virginia. Chronicles of the time reported that she inherited about \$2,000,000. See "Katherine Elkins Divorced from Hitt," The New York Times, 1922, 12 January 1922.

573 “An American Bride for Italian Prince,” The Miami Herald 1, no. 346 (1911, 31 October
} 1911): 1 . 
developed again "in an American environment. ${ }^{, 574}$ The young metropolis had become a seat of hybridization, where old and new worlds met. Miami's society recreated an Italian setting of historical musings, a contemporary court where the new Western aristocrats (of blood and of money) traded new alliances. ${ }^{575}$ The name chosen for Flagler's hotel, where much of this action was staged, suited the purpose, and its magnificence made a statement about its guests' social status. The mélange of the architectural urban grandiosity and the historical past it conjured within an unexpected landscape of citrus and coconut groves, swamps, and palms perfectly symbolized the new hybrid Miami.

\section{The Mediators}

Besides courtly love affairs between Italian noblemen and wealthy American commoners, in 1921, the Miami Herald informed its readers almost daily on the developments of another love story set in Miami. This time the setting was different, and so were the protagonists. ${ }^{576}$ The reports told how an Italian girl, Adele Bonomo, (or

\footnotetext{
${ }^{574}$ Frederick Jackson Turner, "The Significance of the Frontier in American History," conference presentation at the 1893 World's Columbian Exposition, American Historical Association (Chicago, 1893).

${ }^{575}$ Historian Pierre Nora differentiated "milieux de mémoire" (environment of memory) and "lieux de mémoire" (places of memory). He called the real environment of memory "milieux de mémoire", and the static representation of memory "lieux de mémoire". We live in milieu de mémoire, but we observe "Lieux de mémoire". See Pierre Nora, "Between Memory and History: Les Lieux de Mémoire," Representations 26, no. Special issue (1989), 7-24.

576 "Please Find Him, Pleads Italian Miss Signorina Adele Weeps as Her Sailor Boy Still Stays Away," The Miami Herald 11, no. 53 (1921, 17 January 1921): 1; "Pretty Italian Girl's Wedding to End Tale Rivaling 'Evangeline'," The Miami Herald 11, no. 59 (1921, 23 January 1921): 1; "Italian Maid Will Marry Her Sailor. Marriage License Issued to Signorina Adele Bonino Who Followed Lover Across Seas to Miami," The Miami Herald 11, no. 79 (1921, 12 February 1921): 1; "Italian Maid Sends Sweetheart Carfare. Sailor Arthur Kemp Wires and Adele Sends Him Necessary Lire," The Miami Herald 11, no. 56 (1921, 20 January 1921): 1. According to the story, Arthur Kemp was in the U.S. Navy during World War He fell ill and Adele Bonino, or Bonomi, assisted him. A romance began, and Arthur promised to marry her
} 


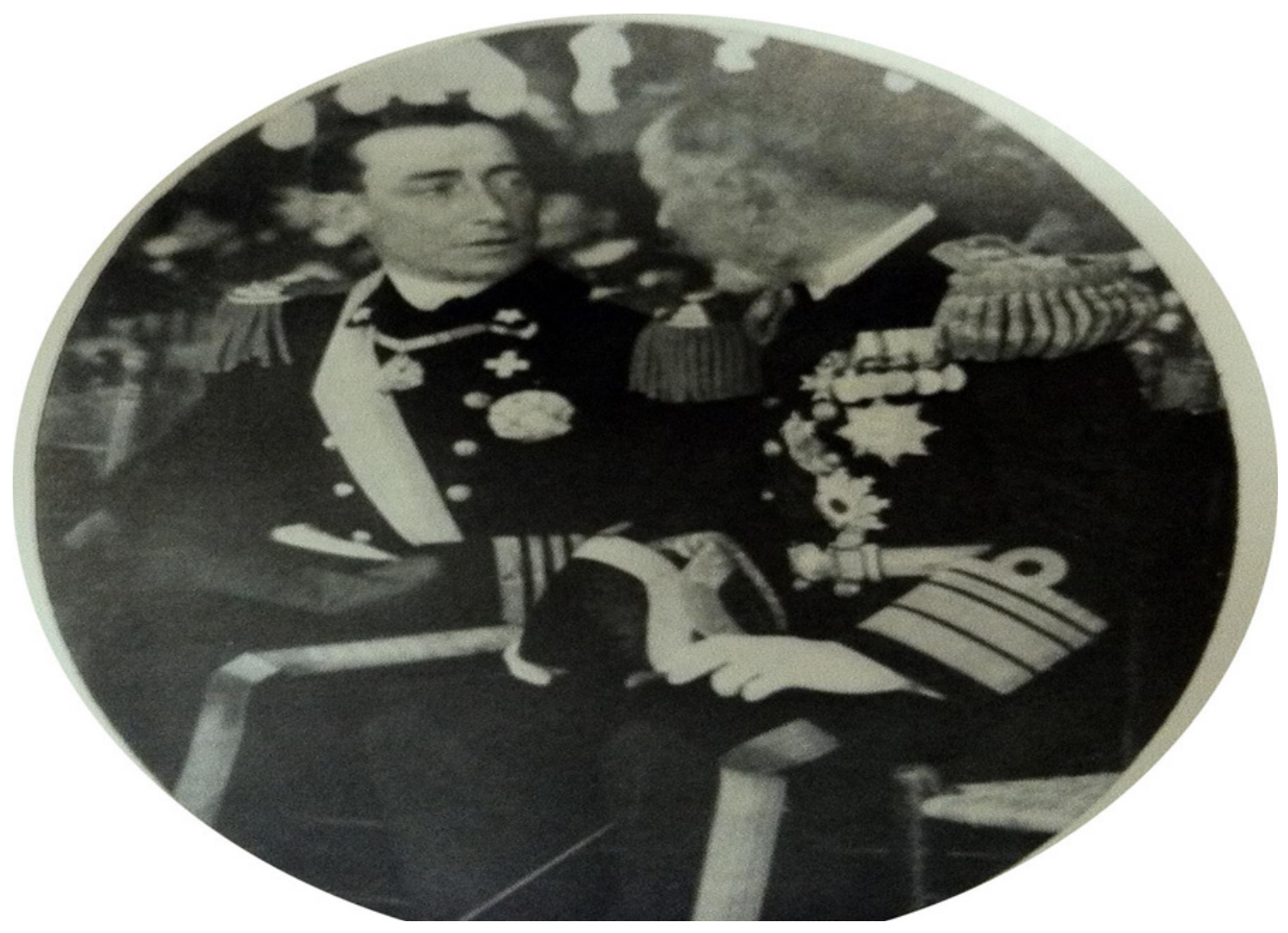

Figure 21. Duke of Abruzzi with Vice Admiral Ijuin at the Jamestown Exposition. Postcard from the museum's collection of General Baron Kuroki Tamemoto and others saluting U.S. Marines at the Jamestown Exposition on May 13, 1907. Source: http://hamptonroadsnavalmuseum.blogspot.com/2013/05/japanese-military-officers-atjamestown.html.

Bonino), and an American sailor, Arthur Kemp, met in Italy, fell in love and became separated when the sailor returned to the United States. Adele was determined to fulfill their wedding promise and reached Miami, where Kemp said he worked as electrician. Adele looked for the man in Miami's business quarters, in the hospital, and finally resorted to the police for help. She finally found him. The newspaper articles conveyed a feeling of amused sympathy at the girl's struggles. The language of these articles offers

upon his return to the United States, where the girl would follow him. For a number of unfortunate circumstances, the two were divided during the crossing of the Atlantic. Arthur had told Adele that he worked as electrician in Miami, and there she went in her hope to find him. 
insights about the writers' perception of Italy and Italians. Writers for the Miami Herald used many positive adjectives when introducing the girl and recounting her deeds both in Italy and in the United States. They described her as 'pretty' in all articles; on January 20, she became 'bewitching', 'black-haired', and 'despondent' like Carmen when she learned that Arthur "failed to put in his appearance", again showing the mix of Mediterranean influence, i.e. confusing and conflating a Spanish gypsy with an Italian girl. ${ }^{577}$ Adele was either a maid, or a 'miss signorina'. ${ }^{578}$ The association of the word 'miss' with its Italian translation illustrates the authors had familiarity with the Italian language but did not know how to use it. Unfortunately, their knowledge of Italian geography was faulty. On January 17 and 20, Adele was stated to have been born in Genoa, Italy; on January 23, she was from Alessandria, Piemonte, but in the same article, a few lines below she was again described as Genoan. ${ }^{579}$ Adele Bonino did not speak English well and the authors of one of the articles utilized quotations to emphasize this

Last night $[\ldots]$ she told the story of that long voyage and what it meant to her to give up mother, father, sisters, and brothers to find, somewhere in America, the 'beeg' handsome boy that she had nursed back to health in her father's home at Genoa, and whom she had learned to love." 580

577 "Italian Maid Sends Sweetheart Carfare. Sailor Arthur Kemp Wires and Adele Sends Him Necessary Lire,” The Miami Herald 11, no. 56 (1921, 20 January 1921): 1.

\footnotetext{
578 "Please Find Him, Pleads Italian Miss Signorina Adele Weeps as Her Sailor Boy Still Stays Away," The Miami Herald 11, no. 53 (1921, 17 January 1921): 1

579 "Italian Maid Sends Sweetheart Carfare. Sailor Arthur Kemp Wires and Adele Sends Him Necessary Lire," The Miami Herald 11, no. 56 (1921, 20 January 1921): 1; "Pretty Italian Girl's Wedding to End Tale Rivaling 'Evangeline'," The Miami Herald 11, no. 59 (1921, 23 January 1921): 1.

580 "Pretty Italian Girl's Wedding to End Tale Rivaling 'Evangeline'," The Miami Herald 11, no. 59 (1921, 23 January 1921): 1.
} 
Readers had already realized this fact, because in the January 17 issue they had read that "Signorina Adele Bonomo, in broken English, with tears in her eyes" had pleaded to local police. ${ }^{581}$ In every article, the girl emerged as pretty and determined to overcome difficulties of any kind.

However resourceful, Adele was still a foreigner with broken English and only one contact in the United States-Kemp, who was described in the same articles as passive and resourceless. ${ }^{52}$ She sought assistance from the police, and her case was widely publicized, but it is unclear whether in the process she also received help from members of the Italian community in Miami. ${ }^{583}$ Regardless of whether she actually did or not, Italians who would have been capable of assisting her-i.e., educated, wellconnected, and able to navigate official channels - were certainly present in Miami at the time. One such individual, for instance, appears in the records of a tragic accident that took place a few months after Adele's arrival.

Frank Angelo Croff, like Adele, originated from Genoa. Born on February 27, 1893, he was an ambitious immigrant who apparently advanced within South Florida's society without the support network of an established Little Italy. A rookie Miami Police motorcycle officer, he died in the line of duty on May 22, 1921when he tried to stop

\footnotetext{
581 "Please Find Him, Pleads Italian Miss Signorina Adele Weeps as Her Sailor Boy Still Stays Away," The Miami Herald 11, no. 53 (1921, 17 January 1921): 1.

582 "Please Find Him, Pleads Italian Miss Signorina Adele Weeps as Her Sailor Boy Still Stays Away," The Miami Herald 11, no. 53 (1921, 17 January 1921): 1.

583 "Please Find Him, Pleads Italian Miss Signorina Adele Weeps as Her Sailor Boy Still Stays Away," The Miami Herald 11, no. 53 (1921, 17 January 1921): 1.
} 
Miami resident William P. McCarthy, allegedly an alcoholic, who was speeding his Cadillac along N.E. 2nd Ave. He was struck and pinned with his motorcycle under the Cadillac for two blocks before the car hit another vehicle, injuring three others. ${ }^{584}$ The accident highlighted the horror of an officer killed in the line of duty; however, it also offers insights into the upward mobility of an Italian immigrant living in Miami. Details of Officer Croff's biography indicate that the 28-year-old emigrated to the United States in 1900 and became a naturalized citizen in 1914. In New York City, he met and married Marie Antonietta, and the couple relocated to Miami and had three children. The 1918 City Directory lists his name and his profession as chauffeur for the East Coast Lumber \& Supply Co., a job he retained until he joined the Miami Police Department a few months before the accident. ${ }^{585}$ Officer Croff's story exemplifies that at least some immigrants could work themselves into respectable positions within the hybrid society of Southeast Florida. Being Italian did not necessarily limit the social possibilities available to individuals.

\footnotetext{
${ }^{584}$ William Wilbanks, Forgotten Heroes: Police Officers Killed in Early Florida, 1840-1925 (Padukah, KY: Turner Publishing Company, 1998), 165-7; United States Federal Census, 1920.

${ }^{585}$ Allan Parrish Reid, Official Directory of the City of Miami, Florida, Including General Information Concerning Churches, Lodges, Societies, City Directory (Miami), 252; William Wilbanks, Forgotten Heroes: Police Officers Killed in Early Florida, 1840-1925 (Padukah, KY: Turner Publishing Company, 1998), 165-7.
} 


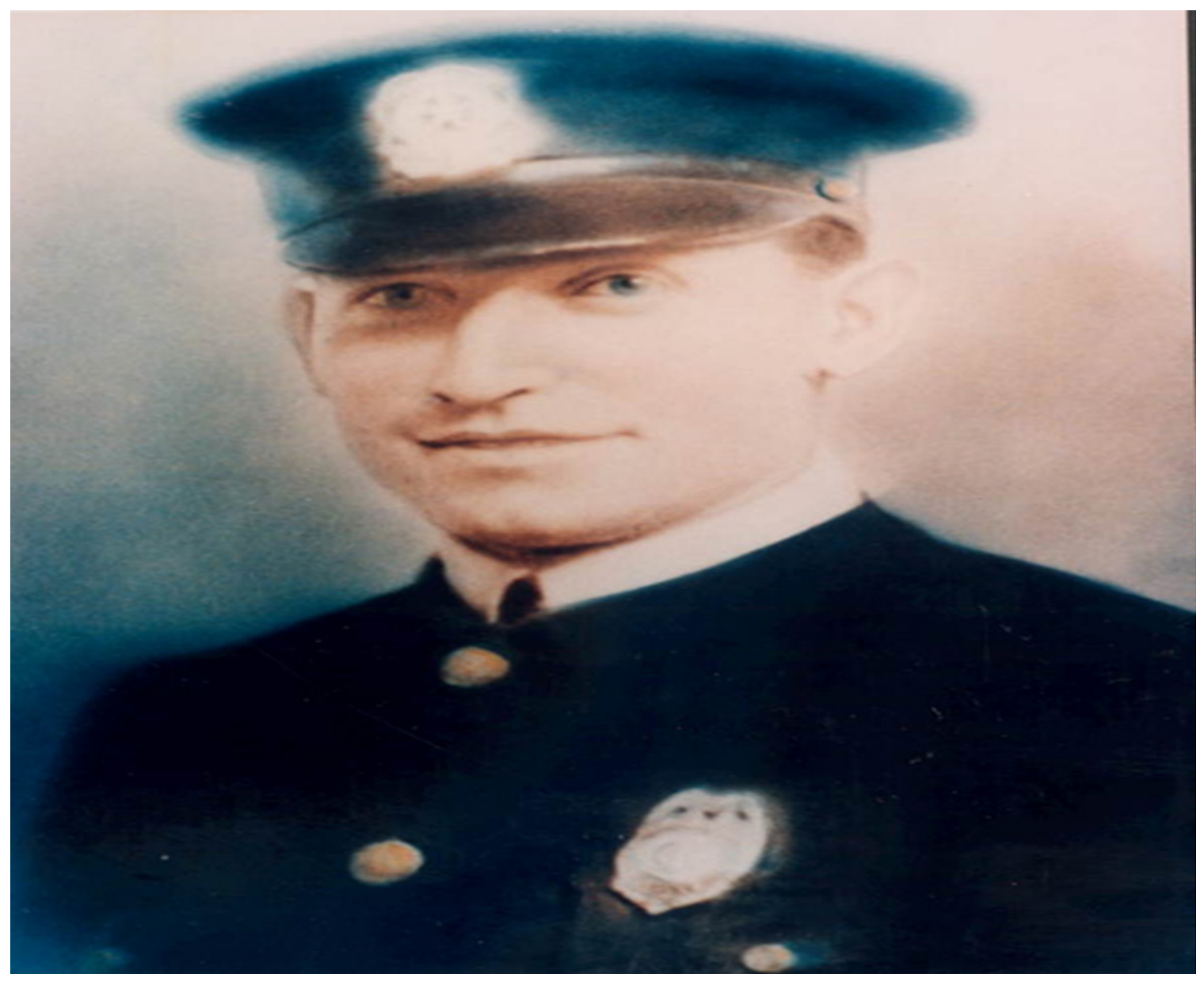

Figure 22. Portrait of Miami Police Department motorcycle officer Frank Angelo Croff. Photoprint, 19--. Source: State Archives of Florida, Florida Memory, http://floridamemory.com/items/show/13813.

\section{The Teachers and the Learners}

Contemporary newspapers offer further illustrations of the Italian presence in Miami. In 1915, in Dade County, “a woman of Italian birth" requested "the establishment of a school for foreigners, who would like to learn the English language at least. ${ }^{, 586}$ The

586 “Attendance Officer Has Nearly Finished Census,” The Miami Herald 5, no. 330 (1915, 26 October 1915): 8 . 
woman's desire to learn English appeared in a census conducted by Dade schools' officer Cora M. Bain (1875-1934). Dade was the first county in the state to adopt a new compulsory school attendance law, and Bain became the attendance officer. ${ }^{57}$ In this role, she conducted a census of children of school age in Miami. By October 26, 1915, she had listed the names of two thousand children, but the list continued to grow as she completed her work. ${ }^{588}$ The Miami Herald's article that circulated this information indicates that "several requests were handed in by people who would like the opportunity to attend a night school". ${ }^{89}$ Bain's investigation is significant because it brings common people's voices to us. Among these, was the Italian woman who wished to learn English.

In the 1910s, symbols and signs of an educated Italianità continued to expand among the members of Miami's middle class in parallel, and often in contrast, with the deeds of Italians actually in residence. Prominent examples include the opening of a school of opera and a "Montessori" school and the staging of a concert that offered a mélange of Italian and American music. ${ }^{590}$ Far from Colored Town and only three blocks

\footnotetext{
587 “Attendance Officer Has Nearly Finished Census,” The Miami Herald 5, no. 330 (1915, 26 October 1915): 8.

588 “Attendance Officer Has Nearly Finished Census," The Miami Herald 5, no. 330 (1915, 26 October 1915): 8 .

589 “Attendance Officer Has Nearly Finished Census," The Miami Herald 5, no. 330 (1915, 26 October 1915): 8 .

590 "Verdi School of Opera and Oratorio," The Miami Herald 8, no. 341 (1918, 10 November 1918): 3; "Concert Tonight Will Offer Varied Music. American and Italian Selections Will be Given in Miami Beach Church," The Miami Herald 13, no. 20 (1922, 15 December 1922): 8; "For the Promotion of Italian Theatrical Art," The Miami Herald 8, no. 329 (1918, 29 October 1918): 2; "Pupils of Allapattah School to Parade as Gipsies During Fete," The Miami Herald 11, no. 10 (5 December 1920): 6; "Italy Seems to Have Been Home of American Trust," The Miami Herald 1, no. 318 (19 October 1911): 3.
} 
away from the Royal Palm Hotel was Ms. Urania Cecilia Glaser's Verdi Opera School. The Verdi School provided classes in voice culture, piano instruction, classical and characteristic dancing, in four languages. Curiously, Urania Cecilia's two Italian first names were paired with a non-Italian last name, Glaser. Whether this is due to a marriage to a non-Italian or an attempt by Urania Cecilia, clearly a highly cultured individual, to give the appearance of a diverse background is unclear, though both would be revealing possibilities.

Not insignificantly, the Miami Herald placed Ms. Glaser's advertisement next to one that hinted at certain aspects of Italianità that continued to exercise influence on special groups in the city. The advertisement for a "Montesorri [sic] School, Kindergarten and Primary Classes" did not provide information on the expertise and services offered. This ad omitted the address but listed the telephone number (773-R1), suggesting that it was targeted at individuals who could afford to have a telephone in their home a rare item at the time the ad was published in $1917 .{ }^{591}$ The principal of the school was confident that the viewers of the brief ad would recognize pedagogue Maria Montessori (1870-1952) hopefully better than the writer of the ad or the editor of this section of the newspaper knew how to spell her name. In Italy, Montessori had recently conducted experimental research with disabled children and had developed a pedagogical method to educate those

\footnotetext{
591 "Montesorri School," The Miami Herald 7, no. 311 (1917, 10 October 1917): 3; "Verdi School of Opera and Oratorio," The Miami Herald 7, no. 311 (1917, 10 October 1917): 3.
} 
not affected by disturbances as well. ${ }^{592}$ Only a few years before the advertisement appeared in Miami, in 1906, Maria Montessori had established a day-care school, the Children's home, (Casa dei bambini) for young children (2-6) in a low-income housing area of Rome's San Lorenzo district. This experience confirmed her vision that pedagogy was the source of transformation of society. Montessori said of the children in San Lorenzo that they were not "born into the light" and that only programs of social reform like her Case could rescue them, and with them a generation of individuals, from darkness. ${ }^{593}$ In 1913 Montessori offered a workshop in Rome attended by visitors from the Americas, India, Africa, and Australia. Her research and publications were translated in many languages, and between 1909 and 1914 over two hundred books and articles on the Montessori method and philosophy were published in the United States. ${ }^{594}$ In 1917 , the Montessori exponent in Miami seems to have ignored Montessori's claim to social reform through education: the Montessori school advertised in the newspaper, just like the Verdi School, and was certainly not for all children in Miami. Nevertheless, the opening of such institutions at this time provides further indication that Miami was fascinated by the Italian brands of excellence; Italian 'products' of quality continued to exercise imaginations in Miami.

\footnotetext{
${ }^{592}$ Marjan Schwegman, Maria Montessori, l’Identità Italiana (Bologna: Soc. Ed. Il Mulino, 1999).

${ }^{593}$ Valeria Babini, Sarah Morgan, and Daniel Pick, "Science, Feminism, and Education: The Early Work of Maria Montessori,” History Workshop Journal 49 (2000): 63.

${ }^{594}$ Valeria Babini, Sarah Morgan, and Daniel Pick, "Science, Feminism, and Education: The Early Work of Maria Montessori," History Workshop Journal 49 (2000): 45.
} 


\section{The Musicians}

In 1922, a group of Tyrolean musicians held a concert at a church in Miami Beach. This was not an important stage, as Miami Beach had not yet become an alluring location. ${ }^{595}$ This event, however, is key to understanding the nuances of Italianità and identity in this region. The American organizers of the concert were seeking an "opportunity to study contrasts in the music of America and Italy". They invited Tyrolean musicians to perform music "distinctly Italian in character." ${ }^{, 596}$ Curiously, Tyroleans are (and were) known as yodeling mountaineers, or as minstrels of Tyrol. Up to the end of World War I, Tyrol was an area in Trentino Alto Adige, in Northeast Italy, contended by Italy and Austria. It was annexed to Italy only in 1919. So, Tyrolean musicians, who had become Italian (at least officially) three years earlier and who probably spoke German more fluently than Italian, accepted the invitation to perform Italianità on a secondary stage in South Florida. This suggests the malleability of Italianità and its performers in this neo-Mediterranean context. The Tyrolean musicians not only accepted to represent the Italian character, which we have seen in the previous chapters as being hard to conceive and achieve, but even executed arias that specifically characterized Southern regional identities. The repertory chosen by the American producer, staging director, and musician Frank P. Stanton (1900-?) included, among other pieces, "La Siciliana", from

\footnotetext{
${ }^{595}$ Howard Kleinberg, "Miami Beach,” in Miami's Historic Neighborhoods. A History of Community, Becky Roper Matkov (San Antonio: Historical Publishing Network), 44.

596 "Concert Tonight Will Offer Varied Music. American and Italian Selections Will be Given in Miami Beach Church,” The Miami Herald 13, no. 20 (1922, 15 December 1922): 8.
} 
La cavalleria rusticana by Mascagni, and "Santa Lucia", a Neapolitan folk song-both performed by Stanton — and"La donna è mobile", from Rigoletto by Verdi, and the Neapolitan serenade "O sole mio"- performed by the Tyroleans. ${ }^{597}$ Missing clear presumptions about a common, collective Italian identity, the Tyrolean group accepted to role-play Italians for pay, tapping into an imaginary pan-Italian cultural repertoire. Stanton and the audience also embraced the Italian character of the evening clearly assuming that Italians could be thought of as one people. This highlight the commodification of cultural stereotypes which leads outsiders to turn into something they were not, for money. Like real estate, culture was for sale as well. The Tyroleans embraced the opportunity like any other outsider would have done. The divisions and marginalization between diverse communities of emigrants discussed in previous chapters were silenced in the Caribbean area, where all groups were complicit in playing to the construction of an imagined Italianità.

\section{Vizcaya: a World of Artists, Stoneworkers, and Chauffeurs}

As in Spain's Golden Age, Italy's Renaissance, Greece's Classical period, and the France of Louis XIV, wealthy new American patrons in Southeast Florida opened their mansions to artists and specialized workmanship to create a camp fantasy of what they thought would sell well in the new Southern American frontier. In Deering's case, the main players were the sculptors and stonecutters who contributed to the realization of his

\footnotetext{
597 “Concert Tonight Will Offer Varied Music. American and Italian Selections Will be Given in Miami Beach Church," The Miami Herald 13, no. 20 (1922, 15 December 1922): 8.
} 
Miamian villa, Vizcaya. Spanish in its name and decorated with Italian and French features in a tropical setting, Vizcaya was not intended as a simple reiteration of old palatial models, but as "the serendipitous product of several imaginations, a true meeting of artistic minds" in true 'nouveau riche' style. ${ }^{598}$ The Italians Ettore Pellegatta (18811940) and Edoardo Camilli (1881-?) dedicated their art, along with unknown workers, many also of Italian origin, who committed their labor, to realize the visions of Vizcaya's architects. While it is possible to sketch anecdotes of Pellegatta's and Camilli's lives in Miami and in Italy between 1910 and 1925, and to glimpse at the activity of a few expert laborers such as De Salvo, Sam Bucci, Frank de Carlo, Joe La Morte, Victor Quardri, and Mencinni, a number of unskilled workers remain unnamed on Vizcaya's daily time sheets and pay rolls. ${ }^{599}$

Indeed, Ettore Pellegatta's status within Vizcaya's artistic community is ambiguous. His biographical data in the 1968 Encyclopedia of American Biography details that he was born in Viggiu, near Milan, Italy, on February $6^{\text {th }}, 1881$. Son of a sculptor, Pellegatta studied at the Milan Academy of Art and, after serving two years of military service, came to the United States in $1901 .^{600}$ Pellegatta worked on several sculptural projects in New York and Washington, and in 1915 moved to Miami to

\footnotetext{
${ }^{598}$ Witold Rybczynski and Laurie Olin, Vizcaya: An American Villa (Philadelphia: University of Pennsylvania Press, 2007), 9.

${ }^{599}$ John Cruikshank, from Freeport, New Jersey, was the contractor responsible for the stonework
} at Vizcaya.

${ }^{600}$ Edwar Dodge, N., Encyclopedia of American Biography, New Series, vol. XXXVIII (New York and West Palm Beach: The American Historical Company, Inc., 1968), 217-8. 
execute sculptures for Vizcaya. ${ }^{601}$ Despite this noteworthy curriculum, in October 1917, Paist, Vizcaya's architect, proposed to fire him because he was a "good carver but had slowed up considerably so did not compare with the two men kept, either in ability or speed. ${ }^{, 602}$ In flawed Italian, Ettore Pellegatta, by then 36 years old, wrote a letter to Paul Chalfin, Deering's artistic supervisor, pleading to let him, and his family, “... la mia Signora e baby", spend at least the winter before going back to New York. ${ }^{603}$ In this letter, Pellegatta lamented that without Cruikschank, the contractor in charge of the execution of the stonework at Vizcaya, he was pessimistic about the result of the work. ${ }^{604}$ Despite the support of Cruikschank, he seems to have been treated as a simple worker rather than an artist with a reputable portfolio. ${ }^{605}$ Obviously, Pellegatta's pleading was successful: he and his family remained in Miami, where censuses prove that they

${ }^{601}$ In New York, Pellegatta sculpted the lions placed at the main entrance to the New York City Public Library and the capitals in the main nave of the Cathedral of St. John the Divine. Here, he also sculpted the front pediment of Grand Central Terminal and did some work at the Columbia University Building. In Washington, Pellegatta worked on the two sphinxes for the Masonic Temple and on the Cathedral of the Immaculate Conception.

${ }^{602}$ Paist to Chalfin, 7 November, 1917, Vizcaya Gardens and Museum Archive (VGMA).

603 “Dear Sir, Mi prendo la libertà di scriverle in italiano per spiegarmi più bene nelle cose che vorrei esprimermi.” Pellegatta to Chalfin, October 30, 1917, VGMA.

604 “ senza Cruikschank, non vedo piu` una buona riuscita.”

${ }^{605}$ Pellegatta's favorable appraisal of Cruikshank was isolated. Other testimonies painted the contractor in a less favorable light. Consider, for instance, that of Telfer — or Zelfer - (presumably a stone cutter) who wrote to Chalfin in 1917: "Mr. Cruikschank made it so miserable for me there [at Vizcaya] that I was forced to quit about six months ago." Telfer (or Zelfer, the hand-written, signed name has an unclear spelling) to Chalfin, -1917, VGMA, 42-5. 
(“Hector Peligata and wife Gina/Lina) lived until the 1930s. ${ }^{606}$ After all, even if 'slow,' good stone carvers were very much needed at Vizcaya.

The July 17, 1916, Minutes of the Committee of the Vizcaya Project register Paul Chalfin's statement that the stone carvers' contractor, Cruikschank, "had infinite troubles in getting men, and it is apparently the prosperity of the country which is making it difficult to get stone carvers" ${ }^{607}$ At the same meeting, Ingalls, one of the architects, made references to over six thousand stone carvers working on site. ${ }^{608}$ This conversation offers a clear idea of the magnitude of the project, the volume of the investments involved, the necessary administrative structure, and the problems arising from recruiting labor. Payroll records and account books of the general contractors George Sykes, Fred T.Ley, McGinnis, and Triggs, along with correspondence between Chalfin and Deering, trace transactions that combined art and business. Chalfin and Deering discussed hourly pay, union tariffs, personnel restlessness, and arranged to get what, or who, they wanted: De Salvo, decorator, to work on a bookcase; Sam Bucci, tile setter, to work on the Farm House; Joseph Santini, boat captain, to pilot Deering's houseboat Nephente. Given the enormous scale of the project, one of the questions regarding the construction of Vizcaya centered on the provenance of the workforce. The proximity of the conclusion of the East Coast Railway extension project (1912) to the dates of the construction of Vizcaya and

${ }^{606}$ U.S. Census 1920; 1930.

${ }^{607}$ Minutes of the Committee, July 19, 1916, VGMA, 42-3.

${ }^{608}$ The minutes state "6007 stonecarvers." The number must have aroused disconcert, because it is underlined in the document. See Minutes of the Committee, July 19, 1916, VGMA, 45. 
the wooden bridge connection between Miami and Miami Beach (both begun in 1913) is noteworthy. At the close of Flagler's venture, many Italian laborers became available to work on Fisher and Collins' and Deering's construction projects.

Not all Italians looking for a job in Miami were construction workers, and many had qualities that made them especially competitive, like those with military exemption and American citizenship. Miami offered no excuse for idleness. Job offers varied: laborers, doctors, entrepreneurs, artists, merchants, and maids were all in high demand within the burgeoning city. Once work on his mansion was completed, James Deering concentrated on staffing his household. For instance, he corresponded for three years with his employees on the subject of chauffeurs. Far from being mere administrative trivia, these letters supply multiple angles from which to observe Italian-American relations from 1917 to 1920, particularly when World War I was ongoing.

Up to 1915, the number of Italian immigrants naturalized in America swelled because the newly arrived were entitled to claim naturalization. But American and Italian concepts of naturalization clashed on the issue of Italian-Americans' duties, attachment, and military obligations. ${ }^{609}$ The Italian government surrendered the responsibility of supporting its subjects economically and socially and recognized the renunciation of Italian citizenship in a foreign country but stipulated in the Civil Code that the loss of Italian citizenship did not imply an exemption from past obligations, including military

\footnotetext{
${ }^{609}$ Bahar Gursel, "Citizenship and Military Service in Italian-American Relations, 1901-1918" Journal of the Gilded Age and Progressive Era, 7 (2008): 353-5.
} 
service, especially at times of "general mobilization". ${ }^{610}$ Of course, Deering wished to hire Italians or Italian-Americans who were exempt from compulsory military service and could not be expatriated to Italy to fight in World War I. Edoardo Cammilli's case proved that James Deering's apprehensions were realistic.

Deering hired Cammilli to produce sculptures for Vizcaya, expecting their collaboration to be a long and fruitful one. Therefore, he was surprised and disappointed when Cammilli elected to return to Italy just one year after he had been hired. "Prof. Edoardo Cammilli," as Chalfin and Deering sometimes called him — thus recognizing his status in Italy—was a Florentine sculptor residing and working in New York. Architects Witold Rybczynski and Laurie Olin state that he had been a professor in Florence before the war and that, after a brief time in the Italian army, he left Italy for the United States, where he arrived penniless. ${ }^{611}$ In 1917, Chalfin found the Florentine sculptor and hired him to produce four caryatids to frame the twin grottoes in the Vizcaya garden at a low price. ${ }^{612}$ Cammilli only produced four clay models, never completing the commission because he had to return to Italy for war service. His premature departure justified Deering's premonitions, expressed in a letter dated September 23, 1918, to Chalfin:

${ }^{610}$ see US Secretary of State ad interim, Foreign Relations of the United States: Diplomatic Papers, 1915, Secretary of State ad interim to Sen. Henry Cabot Lodge (Washington, 1915) and G.E. Di Palma Castiglione, "Italian Immigration Into the United States, 1901-4," American Journal of Sociology, Sept. 1905 (1905) in Bahar Gursel, "Citizenship and Military Service in Italian-American Relations, 19011918," Journal of the Gilded Age and Progressive Era, 7 (2008): 358; 363.

${ }^{611}$ Witold Rybczynski and Laurie Olin, Vizcaya: An American Villa (Philadelphia: University of Pennsylvania Press, 2007) 183.

${ }^{612}$ Chalfin to Deering, September 23, 1918, VGMA 
[I] will say that it is very unfortunate that we ever contemplated the employment of the Italian sculptor facing as he does the alternative of refusing the call of his country or leaving our work wherever it happened to be. I blame myself that I should have considered the proposition in the first place. Since we have gone so far, however, I suggest that you write him a proper kind of letter, saying that we expect him to do the work as soon after the war is over as conditions may be sufficiently normal to justify us in going ahead with the work. ${ }^{613}$

Cammilli expressed his willingness to honor his contract with Deering by going back to Miami to complete the caryatids on the condition that he receive additional commissions that would let him "make a little money and cover my debts made in New York". 614

Deering's answer, through Chalfin, was abrupt:

After studying your [letter] carefully my own feeling is that I should not assure you of any other work in America except this particular piece of work.[...] I must not make you a promise of any [other] work, and I shall therefore conclude not to ask you to return. ${ }^{615}$

By returning to Italy in late 1918, Cammilli closed the door to future work relations with Deering, who was determined not to revive a collaboration that had revealed to be "unfortunate." $" 616$.

In contrast to Cammilli, Tito Ferri, who was an American citizen and exempt from military service, was a good candidate. He certainly made an impression on Chalfin, who wrote in a letter to Deering that he seemed to belong "to the same intelligent and

\footnotetext{
${ }^{613}$ Chalfin to Deering, September 23, 1918, VGMA.

${ }^{614}$ Cammilli to Chalfin, April 1, 1920, VGMA.

${ }^{615}$ Chalfin to Cammilli, May 18, 1920, VGMA.

${ }^{616}$ Chalfin to Deering, September 23, 1918, VGMA.
} 
self-respecting class of Florentines." ${ }^{617}$ Such comment points to the bias that this statement betrayed and is further proof of 'superior' status for Northern Italians. In 1917, after a screening to ascertain his citizenship and military status, he became Deering's chauffeur. Chalfin noted that Ferri spoke "French very well, Italian, of course, perfectly, English quite well enough and with fluency, though by no means in perfection, and [...] Spanish also". ${ }^{618}$ By choosing to refuse Italy's military call in virtue of his American legal status, Ferri secured his station in Southeast Florida. After three years, Ferri's household included a wife, three children and a relative, Joseph Ferri. Life in Miami was good to the Ferris. Since the beginning of his employment, Tito received salary, lodging and "overcoat, tan pettees and two pairs of shoes from Brooks". ${ }^{619}$ For the first two years, Deering and Chalfin kept him in good esteem - "My dear Tito" wrote Chalfin to Ferri on June $25^{\text {th }}, 1919$ - and solicited his expertise in the selection of new personnel for the garage. With Ferri's recommendation, other Italians entered the scene: Ruffo—very "serio...you may conclude that you have been a great benefactor to me", wrote Chalfin to Ferri-and Roger Tinarelli, nicknamed il Bolognese — "very agreeable", wrote Chalfin again. $^{620}$

\footnotetext{
${ }^{617}$ Chalfin to Deering, October 27, 1917, VMGA.

${ }^{618}$ Chalfin to Deering, October 27, 1917, VGMA.

${ }^{619}$ Koch to Deering, November 9, 1917, VGMA.

${ }^{620}$ In Italian in the text.
} 
Even in the case of someone like Ferri, the U.S. participation in the war and the consequences of military preparedness (universal military training and Americanization programs), including the draft, troubled Deering. He wrote on October 1918 to his bookkeeper, Mr. Reilly

As you know, I have been very much concerned about labor matters in Miami. On the one hand, I do not wish to do anything that is not in the interest of the Government nor anything that would hurt the feelings of the Miami community. ${ }^{621}$

On this account

should peace not go as rapidly as we wish and should sentiment exist in Miami, both Joseph and Tito can be put on our two trucks and I can find other chauffeurs as best I may. ${ }^{622}$

He was torn by the desire to count on the work of capable men to run his princely household and the need to comply with the obligations of war, which imposed military conscription on Americans.

Peace eventually was concluded in November 1918, and in 1919 Deering's concern about chauffeurs somehow lessened, because for one year the correspondence with or about the Ferris ceased. In June 1920, however Deering wrote to Chalfin from Vichy, France, one of his last notes about Ferri

You know how fond I am of Joseph [Ferri], the chauffeur. You know also that beyond his pleasant character and the fact that he drives pretty well, he is worthless as mechanic. [...] I feel that I must in justice to myself replace him. Therefore, I want a thoroughly competent chauffeur [...]. Can you kindly put on

\footnotetext{
${ }^{621}$ Deering to Reilly, October 31, 1918, VGMA.

${ }^{622}$ Deering to Reilly, October 31, 1918, VGMA.
} 
foot enquiries on this line? I doubt if I want an Italian unless he is like Ruffo. Another like Tito I could not stand, between you and me. ${ }^{623}$

What ruined the relationship between Deering and Tito Ferri remains undisclosed, as does "the Mrs. Ferri's episode", which appears in another exchange between Deering and Chalfin from the same period

Doubtless Mr. McGinnis has thought it best to spare me these details. I shall be glad to know that we have seen the last of the family. ${ }^{624}$

Despite these comments, it seems that Deering had no prejudices against Italians in general, but rather a particular complaint against some of the Ferri family, Tito in particular, and against those Italians who were like him; he was fond of Joseph Ferri and liked Ruffo. Nevertheless, the last exchanges about the Ferris were not isolated, as correspondence from 1918 reinforces the sense of Deering's ambivalent attitude toward Italians.

Obviously several Italians were still working in the construction of Vizcaya's gardens in 1918, because "An American experienced in large affairs among Italians, who should speak the language" was indispensable according to a letter from Chalfin to Deering. ${ }^{625}$ Chalfin made inquiries at the Italian Chamber of Commerce in New York on July 15, 1918, for a suitable individual. Rasasco had the requisites: he spoke Italian, was born of Italian parents in America, hence was American, and had a university education,

\footnotetext{
${ }^{623}$ Deering to Chalfin, June 25, 1920, VGMA.

${ }^{624}$ Deering to Chalfin, December, 31, 1920, VGMA.

${ }^{625}$ Chalfin to Deering, July 15, 1918, VGMA.
} 
obtained (probably, Chalfin says) at Columbia University. However, Chalfin wrote to Deering on July, 15 1918, “I have done nothing about him, because I think you do not want anyone of the Italian race. ${ }^{, 626}$ This remark conformed to the anti-immigrant feeling present in the 1900-1920s throughout much of the country, as illustrated in Chapters 2 and 3.

Deering's ambivalent attitude and that of the many Midwestern and Northeastern entrepreneurs present in Miami and Southeast Florida since 1896 clashed with their admiration for the Italian culture of the past, which in large part inspired Miami's construction. Nevertheless, this ambivalence never erupted into the sort of racial confrontations that took place in other parts of the United States. The 1891 Louisiana lynching of Italians and the 1922 case Rollins versus Alabama, in which an Italian woman was condemned as non-white, had no repercussion in Southeast Florida ${ }^{627}$ Early settlers and late entrepreneurs continued in their effort to capture particular historic and artistic features connected to Italy and blend them with traits of their own culture to produce an imposing, refined, and civilized milieu. In 1925, real estate developer George Edgar Merrick (1886-1942) declared "Always it seemed to me that there should be the same class of houses and surroundings which were along the shores of the

${ }^{626}$ Chalfin to Deering, July 15,1918 , VGMA.

${ }^{627}$ In 1891, one of the largest mass lynching in U.S. history took place in New Orleans, where 11 Sicilian Americans were lynched by a mob of 10,000 people. See Richard Gambino, Vendetta. The True Story of the Largest Lynching in U.S. History (New York: Doubleday \& Company, Inc., 1977); William Whyte Foote, "Race Conflicts in the North End of Boston," The New England Quarterly 12, no. 4 (1939): 625; Dennis C. Rousey, "Cops and Guns: Police Use of Deadly Force in Nineteenth-Century New Orleans," The American Journal of Legal History 28, no. 1 (1984): $65 .$. 
Mediterranean." ${ }^{628}$ What he and others attempted to create, then, despite the actual roles and perceptions of Italians in the region, were picturesque reminiscences of an interpreted Italianità, one of the many ingredients that composed the MediterraneanCaribbean liminal space of Southeast Florida.

\section{Conclusion}

From 1896 to 1939, members of Southeast Florida's middle and higher classes turned to iconographic facsimiles of Italian national symbols and texts that required the active participation of Italian individuals. In the 1900s, Italians began to leave traces of their presence in Miami and Southeast Florida. They did not act as representatives of a (non-existent) Italian national character, but rather accepted ways they could participate in those expectations and representations of Italianità that were favored by their patrons and employers. Not all had prominent roles, but the majority took an active part in the reenactment. In spite of their small numbers, their actions and the cultural artifacts and symbols of Italianità they fabricated impacted the region's cultural landscape.

Through the actions of this small enclave, we understand how they perceived their identity, what they thought of Italianness, and if they influenced the perceptions and preconceptions of their hosts. Their enclave was not big, but in many instances it made itself known. Some of the laborers contracted to work to Flagler's Florida East Coast Railway between 1906 and 1910, for instance, denounced FEC's peonage practices. A

\footnotetext{
${ }^{628}$ Ellen J. Uguccioni, “Coral Gables,” in Miami's Historic Neighborhoods, a History of Community, Becky Matkov Roper (San Antonio: Historical Publishing Network, 2000), 102.
} 
report written by Italian diplomat Moroni confirmed these allegations and brought to light that hundreds of Italians worked for Flagler under poor conditions.

Some of Flagler's former laborers joined the many others arriving in Miami and other areas of the Southeast, who were attracted by the opportunity to work in the numerous building sites created by a booming economy. Here, Italians faced perceptions and expectations of Italianità that sometimes contrasted with their own beliefs and identities. Nonetheless, they seem to have complied with their hosts' requests. Such is the case, for instance, of the Tyrolean group of musicians who performed Neapolitan songs in a concert promoting Italian and American music. They did it to be accepted, or to advance, if only for a solo engagement and for pay. Italians tried to climb the social ladder and to move to centre stage.

Social advancement was possible, but not easy. At least, not for those Italians living at the margins and whose existence is known to us because they were involved in crimes reported by newspapers articles. Neither country of birth nor race marked Italian immigrants in Southeast Florida, as it did in the Northeastern states. In most cases, what made Italians different was their economic and social status and their potential for assisting in creating the sort of Italianità sought by their hosts and not their actual extraction or sense of identity, not even for the lowest in the social scale.

By studying the small Italian enclave in Miami and Southeast Florida in the years 1896-1939, we are able to comprehend designations of identity and symbolic interactions in a liminal space that seemed to replicate a Caribbean version of the Mediterranean. Learning about Adele, Angelo, Tito, Urania Cecilia, and the few others whose names 
were recorded, along with the many more who remain unnamed, contributes to explaining the absence of a Little Italy in Miami. This was not only because of the small numbers of Italians, but also because they were free to circulate in their new space without resorting to rigid demarcations or to univocal cultural labeling in order to protect their distinctiveness. In Miami and Southeast Florida there was not what historian Robert Harney termed the Italo-phobia of the English-speaking world-i.e., the threatening control by members of the English-speaking host society. ${ }^{629}$ Italians lived in different areas of the city, according to their birth and status in society, but their compliance and entrepreneurship allowed them integration and, if they wanted, assimilation. Italians like Angelo Croff could act as intermediaries between Italy and South Florida and exemplify how Miami and neighboring areas encouraged the development of a community into which foreigners were integrated as English-speaking citizens; a community where being Italian was not a racial marker.

There were certainly more Italians than the official figures suggest. While always important, however, figures are not essential for discussing identity in an environment such as Caribbean South Florida, which took ashore Mediterranean culture and swept back out to sea a modernist, picturesque, Mediterraneo-Caribe version of it. Art, architecture, unwritten codes, symbols, gestures, and common attitudes show that in this

\footnotetext{
${ }^{629}$ Donna Gabaccia, “Global Geography of 'Little Italy': Italian Neighborhoods in Comparative Perspective," Modern Italy 11, no. 1 (2006); Robert F. Harney, "Italophobia: English Speaking Malady," Studi Emigrazione 22, no. 77 (1985).
} 
period there was no quintessential Italian national culture, but only representations of it that élites, farmers, peasants, and immigrants in Italy and Southeast Florida performed.

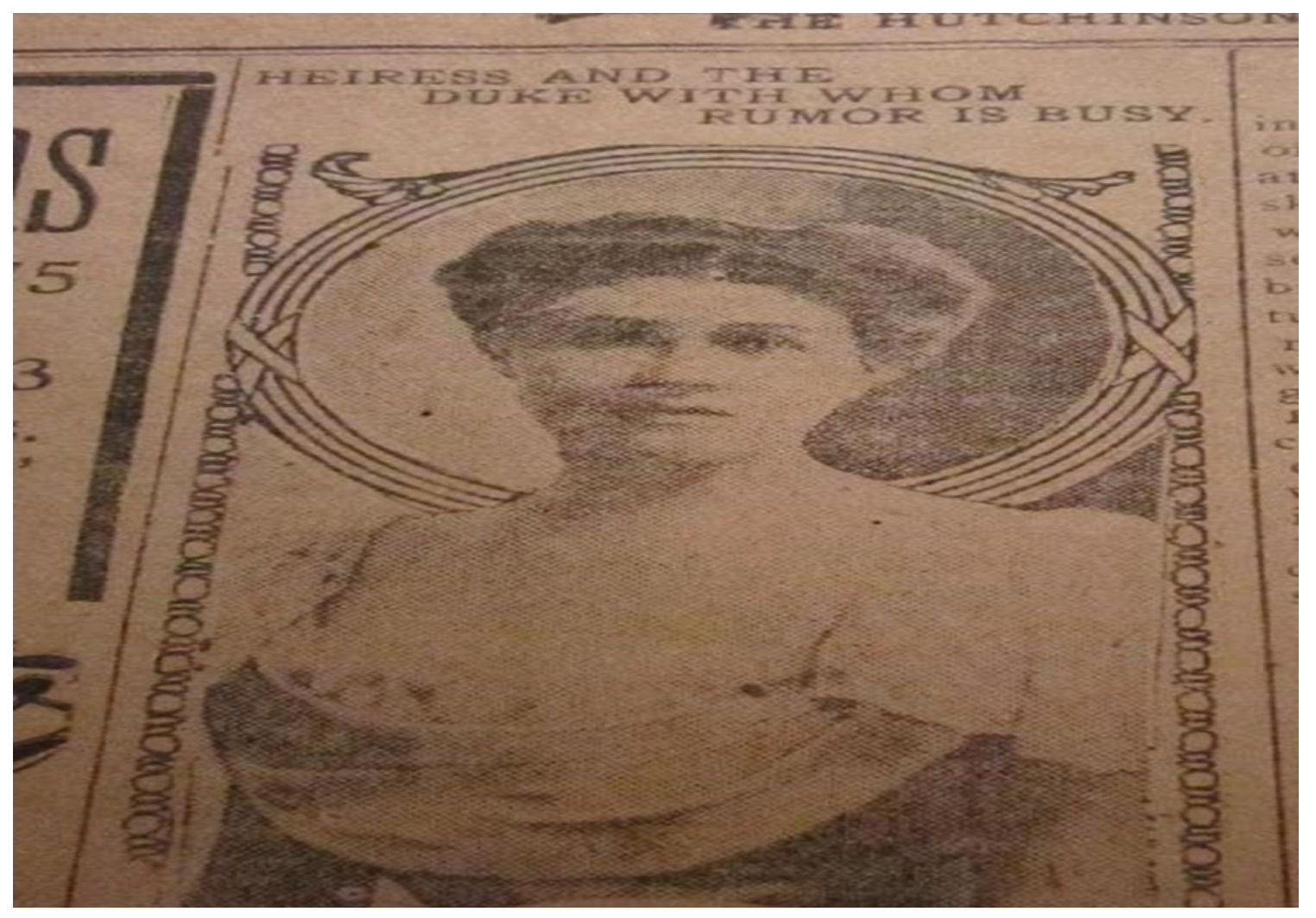

Figure 23. Katherine Hallie Elkins Hitt. Source: The Hutchinson News 8-16-1910. 


\section{CONCLUSION}

Italian identity was still mutable at the end of the $19^{\text {th }}$ and during the first decades of the $20^{\text {th }}$ centuries. Anxiety about identity defined those living in Italy due to the many regional divisions that prevented the formation of a cohesive national character. This insecurity grew as migrants moved and layers of religions, laws, manners, and customs overlapped. Since the birth of Italy as a nation, 'Italians' struggled with the idea of being one people with a specific character that distinguished them from other Europeans.

The political and intellectual élites debated as to what constituted Italianità. In the late nineteenth century, many Italian literati reflected on negative features, "the inertia," "the deadly torpor," or "the atmosphere of negligence and indolence" that enveloped both the place and the people, and searched the causes of their perceived lack of moral and civic attitudes. ${ }^{630}$ The majority of these intellectuals believed that the Catholic Church and the clergy, along with feudal habits and a long process of demilitarization of Italian society, had created a legacy of lack of initiative. ${ }^{631}$ The use of gendered terms,

\footnotetext{
${ }^{630}$ Francesco Venturi, "The Enlightenment in Southern Italy," in Italy and the Enlightenment: Studies in a Cosmopolitan Century, S. Wool (London: Longman, 1972), 209.

${ }^{631}$ Michael G. Broers, "Noble Romans and Regenerated Citizens: The Morality of Conscription in Napoleonic Italy, 1800-1814," War in History 8 (2001): 249-70; Gregory Hanlon, The Twilight of a Military Tradition: Italian Aristocrats and European Conflicts, 1560-1800 (New York: Holmes and Meier, 1998); Silvana Patriarca, Italian Vices: Nation and Character from the Risorgimento to the Republic (Cambridge: Cambridge University Press, 2010), 78; Pietro Verri, "Decadenza del Papato, Idea del Governo di Venezia e Degli Italiani in Generale," in Scritti vari, Giulio Carcano (Firenze: Le Monnier, 1854), 57.
} 
signorino, cicisbeo, damerino (terms used to refer to effeminate men), represented their reproachful comments about the absence of a martial ethos among Italians. ${ }^{632}$

At the close of the nineteenth century, Italian positivist academics, who referred to what they called "scientific evidence" to achieve knowledge, became interested in Italian ethnicity. They categorized differences, stressing the North-South divide that would continue to characterize Italian people in the following decades. Positivists applied empiricism and scientific methodologies to construct explain what they conceive of as proper Italian identity. One of them, Costantino Nigra, wrote that "the diligent investigators of the nation" had to read with attention the content of the "curious document" represented by folk texts. ${ }^{633}$ Both investigators and representatives of a privileged circle of scholars, positivists worked to hear the voices of those people in Italy — peasants and members of the lower classes — who lived unaware of concepts such as nation and nationality received the message through songs and folktales.

Folksongs and folktales, surveys of regional customs, rituals, and ceremonies indicate that individuals in the lower classes thought of themselves exclusively as members of their community of birth and residence. For them, all soldiers and leaders coming from beyond their villages were "invaders." Nationalist leaders resorted to

\footnotetext{
${ }^{632}$ Michael G. Broers, "Noble Romans and Regenerated Citizens: The Morality of Conscription in Napoleonic Italy, 1800-1814," War in History 8 (2001): 249-70; Gregory Hanlon, The Twilight of a Military Tradition: Italian Aristocrats and European Conflicts, 1560-1800 (New York: Holmes and Meier, 1998).

${ }^{633}$ Costantino Nigra, Canzoni del Piemonte: Donna Lombarda, Rivista Contemporanea (Turin: Tipografia economica diretta da Barera, 1888), xi-xxxvii.
} 
gendered approaches to narratives of the nation to promote emotional filial attachment, respect, and the duty to honor and protect Italy, Italia, the Donna Turrita. Unfortunately, Italy's economic circumstances forced many to migrate at the turn of the twentieth century. Between 1876 and 1914, over 14 million people left the country. ${ }^{634}$ These people had not had enough time to recognize and identify with the idea of being "Italian". Migrants left Italy as Northerners or Southerners, and within this category, they brought with them their village identities. With their work abroad, Italian emigrants disproved "the legend of indolence" (dolce far niente) ${ }^{635}$ Migration contributed to efface the image of indolence and laziness that had worried intellectuals in the first years of unification but hindered the creation of an Italian national identity in Italy and abroad.

Racial theories, fears of anarchism and socialism, and nativist reactions to the wave of mass migration at the turn of the century inspired negative opinions about Southern Italians moving to Northern Europe and entering the United States. Italians appeared as "undisciplined Southerners bent on crime and political subversion and lacking in the qualities necessary for democracy". ${ }^{636}$ Italian emigrants had experienced similar racial classification in Italy, as the folksongs and tales presented in this study

\footnotetext{
${ }^{634}$ Bollettino dell'Ufficio del Lavoro, Serie Quindicinale. Rome: (July 14, 1914), p. 272. Quoted in Leonard Covello, "The Social Background of the Italo-American School Child: A Study of the Southern Italian Family Mores and Their Effect on the School Situation in Italy and America," ProQuest Dissertations and Theses (1944): 41-2, New York: New York University, 1944. Also see table in Covello, p. 41.

${ }^{635}$ Angelo Mosso, Vita moderna degli Italiani, (Milan: Treves, 1906).

${ }^{636}$ Silvana Patriarca, Italian Vices: Nation and Character from the Risorgimento to the Republic (Cambridge: Cambridge University Press, 2010), 178.
} 
show, and they did not resent such labeling abroad. Philosopher Herbert Spencer's (18201903) theories on "the survival of the fittest" and Darwinist premises regarding society and human development supported the measures implemented by the Italian government to solve what became known as the Southern Question, which emerged as a problem for the first time in the 1870s. In the early 1900s, the members of the political class reasoned that raising the literacy level was the answer to social inequalities. By 1929, the Italian government had passed eight laws to regulate education and implement discipline, thus shifting the factors that defined Italianità once again: from torpor and laziness caused by historical legacy to North-South racial features, shrewdness or foolishness, and finally to being bourgeois or its opposite in the 1920s, with Mussolini's rise to power. Mussolini's alliance with Hitler in 1938 forced the fascist regime to return to a racial classification of Italians. The Italian nationalist narrative had not only failed in its mission to form a unified Italian people, but actually reinforced race divisions.

With their migration to the United States beginning in the 1870s, Italy's emigrants for the first time acknowledged their Italianità and looked at Italy as a safe haven to recreate in North American cities. Since the beginning of mass emigration to the United States, both Italy's emigrants and their receiving societies had utilized race as benchmark for Italianità. Once Italians arrived to the United States, their un-colored possession, whiteness, protected them from vicious forms of discrimination based on color, but not from the hardships that big cities as New York and Philadelphia reserved for immigrants. Italy's emigrants adjusted to the hostile new environment in the two cities by gathering in 
communities within strict boundaries that protected them from diffidence deriving from what some scholars have termed the "Italo-phobia" of the English-speaking world ${ }^{637}$ The historiography of Italian immigration, which does not show evidence of highly structured Little Italys in Brazil, Argentina, France, or Miami and South East Florida, confirms this argument. ${ }^{638}$ The fact that societies in South America and Southeast Florida were not exclusively English-speaking and Protestant suggests an explanation. In the case of Miami and Southeast Florida, the relatively small number of Italian immigrants is also a good reason. In New York and Philadelphia, Italian immigrants recreated safe communities with kinfolks, relatives, and friends because they perceived their otherness from the groups in the receiving society; they resorted to the creation of boundaries as protection. Italian emigrants to New York and Philadelphia learned to be "Italian" in these new cities. The Little Italys that they recreated, however, presented the same divisiveness of Italy proper, with regional frontiers that separated Neapolitans, Sicilians, Friulani, and other regional groups. But differently from the sequence of events in Italy, in the United States immigrants encountered the host society's requests to act as Italians, according to the idea of Italianità that the cultural movements of the period circulated.

${ }^{637}$ Donna Gabaccia, "Global Geography of 'Little Italy': Italian Neighborhoods in Comparative Perspective," Modern Italy 11, no. 1 (2006): 9; Robert F. Harney, "Italophobia: English Speaking Malady," Studi Emigrazione 22, no. 77 (1985): 6-43.

${ }^{638}$ Donna Gabaccia argues that we find Little Italys in English-speaking places. See Donna Gabaccia, "Global Geography of 'Little Italy': Italian Neighborhoods in Comparative Perspective," Modern Italy 11, no. 1 (2006): 9; Robert F. Harney, "Italophobia: English Speaking Malady," Studi Emigrazione 22, no. 77 (1985): 6-43. 
American Colonial style displayed cultural constructions of Italian art and architecture and became a landmark in the tropical, Caribbean environment of Miami and its neighboring areas. Intellectuals used the term 'picturesque' to identify the peculiar charm deriving from the mélange of old civilization and modern America. "Picturesque" came to represent the modernist outcome of tradition and modernity. ${ }^{639}$ Miami's Anglo entrepreneurs thought of Southeast Florida as an "American Italy", or "the Mediterranean Riviera" even when, at the beginning, there were no traces of Italians. They designed an imaginary stage with symbols of Italian and Mediterranean culture as the backdrop.

Between 1896 and 1939, Caribbean South Florida took ashore Italian culture and constructed a form of Mediterraneo-Caribe modernism. Europe was no longer the Hegelian center of the world, and the Caribbean, a modern Mediterranean, replaced it as a crossroads of cultures. In this function, we recognize Southeast Florida as the birthplace of tropical modernism. Italianità mingled with Spanishness and Frenchness, among other cultural constructs, to become a hybrid product of Southern Mediterranean identity. As actual Italians arrived on the scene, the host society asked that they confirm the signs and symbols deployed in a script that had long been under production. As we have already seen in the case of New York and Philadelphia, not all migrants who arrived in Southeast Florida in this period were aware of being Italians. Maybe some of them understood

\footnotetext{
${ }^{639}$ Modernism is different from modernity. I interpret Modernism as the way of seeing images and words as not representing the world as it is. Modernism shows what is different, or why it is different. For more on Modernism see Walter Benjamin, Illuminations (London: Pimlico, 1999).
} 
Italianità differently. Nevertheless, all seem to have performed their allotted roles when requested.

The few Italians who arrived to Miami and Southeast Florida in the 1900s accepted to participate in this staging of Italianità both as protagonists and co-primaries. The actions of this small enclave help us understand how they perceived their identity, what they thought of Italianness, and whether they influenced the host society's perception of it. In Southeast Florida, Northern or Southern origins did not mark Italians as it did in the American Northeast. Economic and social status made Italians different, and for this reason many Italian immigrants to Southeast Florida strived to climb the social ladder and improve their economic and social standing. Adele Bonino, Angelo Croff, Tito Ferri, Urania Cecilia Glaser, among other Italians who lived in Miami in these years, freely circulated in urban spaces and avoided national or regional boundaries to protect their foreignness. In Miami and Southeast Florida, compliance with social expectations and the demands of entrepreneurship mattered more than place of birth, and Italian nationality represented a practical but not indispensible requisite to perfect the idealized notion of Italianità, practised in this area. 


\section{BIBLIOGRAPHY}

ARCHIVES, PRIMARY BOOKS, AND ARTICLES: AUTHORS NOT CITED

150 Anni di Statistiche Italiane: Nord e Sud, 1861-2011. SVIMEZ. Bologna: Il Mulino, 2011.

1850-1950: Cento Anni di Sviluppo del Turismo. _rept. Genoa: Centro di Ricerca dellUniversità di Genova, 2008.

Commissariato Generale dell'Emigrazione. Annuario Statistico Dell'emigrazione Italiana Dal 1876 al 1925. Tech. rept. Rome, 1926.

Commissioner of Health. Tenth Annual Report. Commonwealth of Pennsylvania. Harrisburg: J.L.L. Kuhn Printer to the Commonwealth, 1915.

Krome family. “William J. Krome Key West Extension Papers, 1902-1909.” William J. Krome Key West Extension papers, 1902-1909. M96-1, 900000, 1902-9. Http://dlis.dos.state.fl.us/.

University of Miami, Special Collections, Otto G. Richter Library, Coral Gables.

Vizcaya Garden and Museum Archive, Miami.

Wolfsonian-FIU Rare Books and Special Collections Library, Miami Beach.

"19 Naturalized in U.S. Court Monday Session.” The Miami Herald 7, no. 149 (1917, 1 May 1917): 5.

"An American Bride for Italian Prince." The Miami Herald 1, no. 346 (1911, 31 October 1911).

"Attendance Officer Has Nearly Finished Census." The Miami Herald 5, no. 330 (1915, 26 October 1915): 8.

Atti Officiali Della Esposizione Italiana Agraria, Industriale Ed Artistica Che Avra` Luogo in Firenze Nel 1861. Firenze: M. Cellini e C., 1861.

City of New York, Tenement House Department. First Report. 1. New York, 1903.

"A Beautiful Miami Home. Description of the Charles I. Briggs Residence Nearing Completion at Point View." The Miami Herald 8, no. 342 (1918, 11 November 1918): 2 . 
"Build Balcony Around Pools. Various Improvements at Casino St. John Are Now Under Way.” The Miami Herald 11, no. 347 (1921, 7 November 1921): 4.

"Concert Tonight Will Offer Varied Music. American and Italian Selections Will be Given in Miami Beach Church.” The Miami Herald 13, no. 20 (1922, 15 December 1922): 8.

“Coral Gables Plans Large Development.” Tampa Tribune, 22 March 1925, 41.

Donna Lombarda. Ballad.

"Duke of Abruzzi Now in Miami. Fiancé of Miss Katherine Elkins." The Miami Metropolis 6, no. 22 (1909, 19 January 1909).

"Final Word of Architectural Recognition.” The Miami Herald 9, no. 28 (1919, 20 June 1919): 1.

"Fine Cut Glass and Italian Chine, Advertisement." The Miami Herald 1, no. 218 (14 July 1911): 3 .

“The Finest Dining Room in Miami.” The Miami Herald 10, no. 112 (15 March 1920): 4.

"For the Promotion of Italian Theatrical Art." The Miami Herald 8, no. 329 (1918, 29 October 1918): 2.

From Wilderness to Metropolis. Historic Preservation Division. Miami: Metropolitan Dade County.

“Gallows Awaits Italian Slayer.” The Miami Herald 3, no. 13 (1912, 13 December 1912): 1.

"Go to Florida with Burton Holmes." Springfield Republican, 1926, 11 April 1926, 25.

"Gondolas Carry Guests to Party at Golf Club." The Miami Herald 11, no. 79 (12 February 1921): 7.

"Gondolier of Plants." The Miami Herald 6, no. 87 (Febraury 25 1916).

"Grill Room on Fourth Floor of the New Gallat." The Miami Herald 10, no. 81 (Febraury 13, 1920): 8 .

“An Italian Decoration.” Cambridge Tribune XXVIII, no. 3 (1905, 18 March 1905): 5.

"Italian Maid Sends Sweetheart Carfare. Sailor Arthur Kemp Wires and Adele Sends Him Necessary Lire.” The Miami Herald 11, no. 56 (1921, 20 January 1921): 1. 
"Italian Maid Will Marry Her Sailor. Marriage License Issued to Signorina Adele Bonino Who Followed Lover Across Seas to Miami." The Miami Herald 11, no. 79 (1921, 12 February 1921): 1.

"Italy Seems to Have Been Home of American Trust." The Miami Herald 1, no. 318 (19 October 1911): 3.

"Katherine Elkins Divorced from Hitt." The New York Times, 1922, 12 January 1922. L'Illustration. Journal Universel (1861), 207.

"Latest is 'Venetian Waterway' Residence." Omaha World Herald, 24 October 1926, 36.

“The Laws of Wisconsin.” Madison, Wisconsin: Democrat Printing Company, State Printers, 1889.

"Locked up on a Serious Charge." The Miami Herald 7, no. 2 (1916, 4 December 1916): 3.

"Miami Beach Firm Plans More Homes. Two High Class Italian Villas Will be Erected at Early Date." The Miami Herald 12, no. 51 (1922, 15 January 1922): 7.

The Miami Herald 7, no. 38 (1917, 10 January 1917): 4.

“Miami’s Climate Better Than Naples.” The Miami Herald 5, no. 175 (1915, 24 May 1915): 8 .

Il Momento, 1917, 12 May 1917.

Il Momento, 1918, 1 June 1918.

“Montesorri School.” The Miami Herald 7, no. 311 (1917, 10 October 1917): 3.

"Naturalizations." Naturalization Records. Searchable Database. Genealogy. Sandpoint, Idaho: Bonner County Recording Office.

"New Owner of Casino Visions Great Future for Miami Beach." The Miami Herald 11, no. 145 (1921, 19 April 1921): 4.

"Il Padiglione Italiano All'esposizione Internazionale di Arti Decorative di Parigi." L'Architettura Italiana XX, no. 10 (1925).

"Please Find Him, Pleads Italian Miss Signorina Adele Weeps as Her Sailor Boy Still Stays Away." The Miami Herald 11, no. 53 (1921, 17 January 1921): 1. 
Il Popolo, 1905, 23 September 1905.

Il Popolo, 1906, 14 April 1906.

"Pretty Italian Girl's Wedding to End Tale Rivaling 'Evangeline'." The Miami Herald 11, no. 59 (1921, 23 January 1921): 1.

Public Ledger, 1918, 24 May 1918.

"Pupils of Allapattah School to Parade as Gipsies During Fete." The Miami Herald 11, no. 10 (5 December 1920): 6.

"Pupils of Allapattah School to Parade as Gypsies During Fete." The Miami Herald 11, no. 10 (5 December 1920): 6.

"Renovated Roman Pools for Coming of Season." The Miami Herald 13, no. 7 (1922, 2 December 1922): 3.

“The Royal Palm.” The Tatler, 1897, 16 January 1897, 3-4.

Sommario di Statistiche Storiche Italiane 1861-1955. Tech. rept. Rome, 1958.

“Special Spaghetti Dinner.” The Miami Herald 10, no. 73 (5 February 1920): 4.

"Sunny Isles Property to be the Modern Venice of America Created by the Golden Wand of Millionaire Harvey b. Graves.” The Miami Herald 11, no. 272 (1921, 24 August 1921): 8 .

"Traver Plans Italian Villa with Unique Studio on Beach.” The Mimai Herald 11, no. 105 (1921, 10 March 1921): 9.

"Verdi School of Opera and Oratorio." The Miami Herald 7, no. 311 (1917, 10 October 1917): 3 .

"Wanamaker Advertises Miami's Charms in Philadelphia Paper." The Miami Herald 11, no. 59 (1921, 23 January 1921): 4.

"Will Open Miami Restaurant. Leon DeLeon to be Associated with Mrs. Wilson in New Enterprise.” The Miami Herald 11, no. 345 (5 November 1921): 4.

UNESCO/CLT/WHC, http://whc.unesco.org/en/list/442

U.S. Bureau of the Census, Eleventh Census of the United States. Statistics of population. Washington: U.S. Government Printing Office, 1892. 
U.S. Bureau of the Census, Tenth Census of the United States. Statistics of population. Washington: U.S. Government Printing Office, 1882.

U.S. Bureau of the Census, Thirteenth Census of the United States. Statistics of population. Washington: U.S. Government Printing Office, 1910.

BOOKS AND ARTICLES

Abulafia, David. "Mediterraneans." In Rethinking the Mediterranean. In Rethinking the Mediterranean, William V. Harris, 64-93. Oxford: Oxford University Press, 2005.

Agamben, Giorgio. Categorie Italiane. Studi di Poetica e di Letteratura. Roma-Bari: Laterza, 2010.

Alexander, Jeffrey C., Bernhard Giesen, and Jason L. Mast, ed.s. Social Performance: Symbolic Action, Cultural Pragmatics, and Ritual. Cambridge: Cambridge University Press, 2006.

Alfani, Augusto. Il Carattere Degli Italiani. Florence: Barbera, 1876.

Alianello, Carlo. La Conquista del Sud. Sant'Arcangelo di Romagna: Rusconi Libri, 1972.

------. L'Alfiere. Milan: BUR Rizzoli, 1942.

------. L'Eredità Della Priora. Venosa PZ: Osanna Edizioni, 1963.

Aliano, David. Mussolini's National Project in Argentina. Madison Teaneck: Farleigh Dickinson University Press, 2012.

Amfitheatrof, Erik. The Children of Columbus. Boston: Little Brown and Company, 1973.

Anderson, Benedict. Imagined Communities: Reflections on the Origin and Spread of Nationalism. London: Verso, 1983.

------. Imagined Communities: Reflections on the Origin and Spread of Nationalism. London: Verso, 1985.

Ansaldo, Giovanni. “Grandezza e Decadenza del Perfetto Italiano.” La Rivoluzione Liberale (1924).

------. “Mussolinismo.” La Rivoluzione Liberale (1923). 
Aquarone, Alberto. "Politica Estera e Organizzazione del Consenso Nell'età Giolittiana." Storia Contemporanea 8 (1977).

Archivio Centrale dello Stato. “Tribunali Militari." Tribunale militare del XX corpo d'armata. TM, 1917.

Arnesen, Eric. "Whiteness and the Historians' Imagination." International Labor and Working-Class History, no. 60 (2001): 3-32.

Arsenault, Raymond, and Gary R. Mormino. "From Dixie to Dreamland: Demographic and Cultural Change in Florida, 1880-1980." In Shades of the Sunbelt:Essays on Ethnicity, Race, and the Urban South, Randall M. Miller and George E. Pozzetta, 161-91. New York: Greenwood Press, 1988.

Asor Rosa, ALberto. La Cultura. Storia d'Italia, Dall'unita`a Oggi. Turin: Einaudi, 1975.

------. Genus Italicum. Saggi Sull'identità Letteraria Italiana Nel Corso del Tempo. Torino: Einaudi, 1997.

Babini, Valeria, Sarah Morgan, and Daniel Pick. "Science, Feminism, and Education: The Early Work of Maria Montessori." History Workshop Journal 49 (2000): 4467.

Bagot, Richard. My Italian Years. London: Mills and Boon Ltd., 1911.

Baily, Samuel L. "The Adjustment of Italian Immigrants in Buenos Aires and New York, 1870-1914." The American Historical Review 88, no. 2 (1983): 281-305.

Baj, Serafino. Canti di Guerra e Patriottici. Raccolti e Pubblicati a Cura di Baj Serafino Dedicati Alla Memoria del Compianto Presidente Federale Dei Combattenti di Milano Cap. Giuseppe Cancelliere Animatore Dei Canti di Guerra. Milano: La tipografica, 1933.

Balbo, Cesare. Delle Speranze d'Italia. Capolago Cantone Ticino: Tipografia Elvetica, 1844.

------. Pensieri Ed Esempi. Florence: Le Monnier, 1844.

Balletta, Francesco. Un Secolo di Emigrazione Italiana, 1876-1976. Gianfausto Rosoli. Rome: Centro studi emigrazione, 1978.

Banks, Marcus. Ethnicity: Anthropological Constructions. London and New York: Routledge, 1996. 
Barberis, Walter. Il Bisogno di Patria. Torino: Einaudi, 2010.

Barbiera, R. Le Esposizioni Italiane Tenute Finora, in Palermo e l'Esposizione Nazionale del 1891-92. Milano: Treves, 1892.

-----. Palermo e l'Esposizione Nazionale del 1891-92. In Le Esposizioni Tenute Finora. Milano: Treves, 1892.

Barth, Fredrick. "Boundaries and Connections." In Signifying Identities: Anthropological Perspectives on Boundaries and Contested Values, Anthony Cohen, 17-36. London and New York: Routhledge, 2000.

Barth, Fredrik. "Boundaries and Connections." In Signifying Identities: Anthropological Perspectives on Boundaries and Contested Values, Anthony P. Cohen, 17-36. London and New York: Routledge, 2000.

-----. Ethnic Groups and Boundaries: The Social Organization of Culture Difference. Boston: Little, Brown and Company, 1969.

Bartholf, J. F., and F. C. M. Boggess. South Florida, the Italy of America: Its Climate, Soil and Productions. Charlotte Harbor, Manatee Co., Florida: Ashmead Bros., 1881.

Bauman, Richard. Verbal Art as Performance. Rowley, MA: Newbury House, 1977.

Bauman, Zygmunt. "Making and Unmaking of Strangers." Thesis Eleven 43, no. 1 (1995): 1-16.

Bayor, Ronald H. The Columbia Documentary History of Race and Ethnicity in America. New York: Columbia University Press, 2004.

Bedeschi, G. La Fabbrica Delle Ideologie. Il Pensiero Politico Nell'Italia del Novecento. Rome-Bari: Laterza, 2002.

Beecher, Lyman. A Plea for the West: Six Sermons on Temperance, Sermons on Various Occasions. Cincinnati: Truman \& Smith, 1835.

Benjamin, Walter. Illuminations. London: Pimlico, 1999.

Berberich, Christine. "A Peculiarly English Idiosyncrasy? Julian Barnes's Use of Lists in England, England." The Journal of American, British, and Canadian Studies 13 (2009): 75-87.

Berlet, Chip, and Matthew N. Lyons. Right-Wing Populism in America: Too Close for Comfort. New York: Guilford Press, 2000. 
Bhabha, Homi K. "The Location of Culture." In The Location of Culture. London and New York: Routledge, 1994.

-----. Nation and Narration. London and New York: Routledge, 1990.

Bianchi Bandinelli, Ranuccio. Diario di un Borghese. $<$ Ed $>$ Barbanera, M. Rome: Editori Riuniti, 1996.

Bianchi, Bruna. "I Disobbedienti Nella Grande Guerra." In La Follia e la Fuga. Nevrosi di Guerra, Diserzione e Disobbedienza Nell'esercito Italiano 1915-1918. Roma: Bulzoni, 2001.

Billington, Ray Allen. The Protestant Crusade, 1800-1860: A Study of the Origins of American Nativism. Chicago: Quadrangle Books, 1938.

Blackman, E.V. Miami and Dade County, Florida: Its Settlement, Progress and Achievement. Washington: Victor Rainbolt, 1921.

Blackmon, Douglas A. Slavery by Another Name: The Re-Enslavement of Black People in America from the Civil War to World War II. New York: Doubleday, 2008.

Blunt, J. J. Vestiges of Ancient Manners and Customs Discoverable in Modern Italy and Sicily. London: John Murray, 1823.

Bobbio, Norberto. Una Filosofia Militante: Studi su Carlo Cattaneo. Turin: Einaudi, 1971.

------. Ideological Profile of Twentieth-Century Italy. Princeton: Princeton University Press, 1995.

------. Italia Fedele. Il Mondo di Gobetti. Florence: Passigli, 1986.

Bodei, Remo. Il Noi Diviso. Ethos e Idee Dell'Italia Repubblicana. Torino: Einaudi, 1998.

Bollati, G. "I Caratteri Originali." Storia d'Italia 1 (1972)L'Italiano. Vol. 1 of L'Italiano. Il Carattere Nazionale Come Storia e Come Invenzione.

Bonetta, Gaetano. Corpo e Nazione. L'Educazione Ginnastica, Igienica e Sessuale Nell'Italia Liberale. Milan: Angeli, 1990.

Borgese, Giuseppe Antonio. Goliath: The March of Fascism. New York: Viking Press, 1937. 
-----. "Letter to Carlo Rosselli." Giustizia e Libertà e Il Socialismo Liberale (1935).

Bottai, Giuseppe. Diario, 1935-1944. Giovan Battista Guerri. Milan: Rizzoli, 1982 [orig 1940].

Botteri, I. Galateo e Galatei. La Creanza e l'Istituzione Della Società Nella Trattatistica Italiana Tra Antico Regime e Stato Liberale. Rome: Bulzoni, 1999.

Bouin, P., and C. P. Chanut. Histoire Française Des Foires et de Expositions Universelles. Paris: Baudoin, 1980.

Bouin, Philippe, and Christiane-Philippe Chanut. Histoire Française Des Faires et Des Expositions Universelles. Paris: Baudoin, 1980.

Bourne, Randolph. "Trans-National America." In War and the Intellectuals, Carl Resek, 107-23. New York: Harper \& Row, 1964.

Braden, Susan. The Architecture of Leisure: The Florida Resort Hotels of Henry Flagler and Henry Plant. Gainesville: University Press of Florida, 2002.

Braidotti, Rosi. Transpositions: On Nomadic Ethics. Cambridge and Malden: Polity Press, 2006.

Braun, Emily. "The Visual Arts: Modernism and Fascism." In Liberal and Fascist Italy, 196-216. Oxford: Oxford University Press, 2002.

Briggs, John W. An Italian Passage: Immigrants to Three American Cities, 1890-1930. New Haven \& London: Yale University Press, 1978.

Brigham, Gertrude R. "The New Memorial to Dante in Washington.” Art \& Archaeology, Archaeological Institute of America 13 (1922): 32-5.

Brion Davis, David, ed. The Fear of Conspiracy: Images of un-American Subversion from the Revolution to the Present. Ithaca, NY: Cornell University Press, 1971.

Broers, M. G. "Noble Romans and Regenerated Citizens: The Morality of Conscription in Napoleonic Italy, 1800-1814." War in History 8 (2001): 249-70.

Brunetti, Fausto. L'Italia è una Esperienza Geografica. Manipolazione e Trasfigurazione di una Celebre Frase Metternichiana. Roma: Edizioni Libreria Croce, 2005.

Burke, Peter. Popular Culture in Early Modern Europe. New York: Harper \& Row, Publishers, 1978.

Burkhardt, Jacob. The Civilization of the Renaissance in Italy. London: Penguin, 1990 
[orig. 1860].

Buscioni, Maria Cristina. Esposizioni e "Stile Nazionale" (1861): Il Linguaggio Dell'architettura Nei Padiglioni Italiani Delle Grandi Kermesses Nazionali Ed Internazionali. Firenze: Alinea editrice, 1990.

Buzard, James. "The Grand Tour and After (1660-1840)." In The Cambridge Companion to Travel Writing, Peter Hulme and Tim Youngs, 37-52. Cambridge: Cambridge University Press, 2002.

Calvino, Italo. Italian Folktales. George Martin. San Diego: Harcourt Brace Jovanovich, Publishers, 1980 [1st ed. 1956].

Cannistraro, Philip. "Mussolini, Sacco-Vanzetti, and the Anarchists: The Transatlantic Context." Journal of Modern History 68, no. 1 (1996): 31-62.

Cardoza, Anthony L. Aristocrats in Bourgeois Italy: The Piedmontese Nobility, 18611930. Cambridge and New York: Cambridge University Press, 1997.

Carducci, Giosue. "Ça Ira.” In Prose di Giosue Carducci. Bologna: Zanichelli, 1898.

Carignano, Emmanuele di Savoia. Discorso di S.A.R. Nell'adunanza Inaugurale del 20 Agosto 1860. Keynote address. Atti Officiali Della Esposizione Italiana Agraria, Industriale Ed Artistica Che Avra` Luogo in Firenze Nel 1861. Firenze: M. Cellini e C., 1861.

Carter, Paul. Backstage Handbook: An Illustrated Almanac of Technical Information. Shelter Island: Broadway Press, 1994.

Castelli, Franco. “Per Un’antropologia del Risorgimento.” Editorial, 2011.

Ceccarini, Luigi, and Ilvo Diamanti. "Italiani, Malgrado Tutto." Limes Rivista Italiana di Geopolitica 2, no. 2011 (2011): 23-35.

Cesa, Claudio. Tardo Positivismo, Antipositivismo, Nazionalismo. Florence: Olschki, 1981.

Chalfin, Paul. "Romance of History in the Language of Art." The Miami Herald, 1934, 23 December 1934.

Chandler, Arthur. “The Art Deco Exposition.” World's Fair Magazine VIII, no. 3 (1988).

Chatterjee, Partha. The Nation and Its Fragments: Colonial and Postcolonial Histories. Princeton: Princeton University Press, 1993. 
------. The Nation and Its Fragments:Colonial and Postcolonial Histories. Princeton: Princeton University Press, 1993.

Choate, Mark I. Emigrant Nation: The Making of Italy Abroad. Cambridge and London: Harvard University Press, 2008.

Ciano, Galezzo. Diary, 1937-1943. New York: Enigma, 2002 [orig 1942].

Cipolla, Carlo. Istruzione e Sviluppo. Bologna: Il Mulino, 2002.

Ciresi, Alberto. La Poesia Popolare: Storia Della Critica. Palermo: Palumbo Editore, 1925.

Clark, Martin. The Italian Risorgimento: Still a Controversial Story. Harlow, England and New York: Pearson Longman, 2009.

Clifford, James. "Diasporas.” Cultural Anthropology 9, no. 3 (1994): 302-38.

Cocchiara, Giuseppe. L'Anima del Popolo Italiano Nei Suoi Canti. Milano, 1929.

Cohen, Abner. Custom and Politics in Urban Africa: A Study of Hausa Migrants in Yoruba Towns. London: Routledge \& Kegan Paul, 1969.

Cohen, Anthony. Signifying Identities: Anthropological Perspectives on Boundaries and Contested Values. London and New York. Routledge, 2000.

Colajanni, Napoleone. Latini e Anglo-Sassoni (Razze Inferiori e Razze Superiori). RomeNaples: Presso la Rivista Popolare, 1906.

Collini, Stefan. "The Idea of Character." In National Character and Public Spirit in Britain and France, 1750-1914, R. Romani. Cambridge: Cambridgen University Press, 2002.

Collodi, Carlo. Le Avventure di Pinocchio. Firenze: Giunti Junior, 1998 [orig 1883].

-----. The Adventures of Pinocchio. Oxford: Oxford University Press, 1996.

Colson, Elizabeth. The Social Organization of the Gwembe Tonga. Manchester: University of Manchester Press, 1960.

Cometti, Elizabeth. "Trends in Italian Emigration.” The Western Political Quarterly 11, no. 4 (1958): 820-34.

Comte, Auguste. A General View of Positivism. London: Routledge \& Sons, 1907 [1848 in French; 1865 in English]. 
Coote, Colin Reith. Italian Town and Country Life. New York: Brentano, 1925.

Corner, Paul. "State and Society, 1901-1922." In Liberal and Fascist Italy, Adrian Lyttelton, 27-43. Oxford: Oxford University Press, 2002.

Corradini, Enrico. "Vecchio e Nuovo Nazionalismo.” Il Regno (1914).

Cosco, J. P. Imagining Italians: The Clash of Romance and Race in American Perception, 1880-1910. Albany: State University of New York, 2003.

Covello, Leonard. "Language as a Factor in Social Adjustment." Manuscript. Upper Saddle River, 1937.

Covello, Leonard H. The Social Background of the Italo-American School Child. Leiden, Netherlands: E. J. Brill, 1967.

Crawford, Francis M. The Rulers of the South. New York: Macmillan Company, 1900.

Cresswell, Tim. On the Move: Mobilityin the Modern Western World. New York; London: Routledge, 2006.

Croce, Benedetto. Pagine Sulla Guerra. Bari: Laterza, 1928.

-----. “Poesia 'Popolare' e Poesia 'd'Arte': Considerazioni Teorico-Storiche.” La Critica.

Rivista di Letteratura, Storia e Filosofia 27 (1929): 321-428.

------. Storia d'Italia 1871-1915. Milano: Adelphi, 1991 [orig1928].

-----. Teoria e Storia Della Storiografia. Bari: Laterza, 1943 [orig 1920].

Croucher, Sheila L. Imagining Miami: Ethnic Politics in a Postmodern World. Charlottesville: University of Virginia Press, 1997.

Cyriax, Tony. Among Italian Peasants. London: W.C. Collins Sons and Company, Ltd., 1919.

d'Azeglio, Massimo. Things I Remember (I Miei Ricordi). E. R. Vincent. London: Oxford University Press, 1966.

Dal Passo, Fabrizio. "Il Sistema Scolastico Dalla Fase Preunitaria All'Italia Unita (18481948)." Manuscript in Storia Della Scuola Italiana, 1-77, 2013. 
Dandolo, T. Panorama di Firenze. La Esposizione Nazionale del 1861. Milano, 1863.

Daniels, Roger. Coming to America. New York: Harper Collins Publishers, 1990.

Darwin, Charles. The Origin of Species. New York: P. F. Collier \& Son Company, 1909 [1st edition 1859].

Davidson, James, and Mark Hamilton Lytle. After the Fact: The Art of Historical Detection. New York: Alfred A. Knopf, 1986.

Davis, John A. "Economy, Society and the State." In Italy in the Nineteenth Century, John A. Davis, 235-63. Oxford: Oxford University Press, 2006.

De A. Reid, Ira. The Negro Immigrant: His Background, Characteristics and Social Adjustment,1899-1937. New York: Columbia University Press, 1939.

De Amicis, Edmondo. Cuore. Milan: Oscar Classici Mondadori, 1991 [orig 1886].

De Felice, Renzo. Mussolini Il Duce. Gli Anni del Consenso, 1926-1936. Turin: Einaudi, 1974.

-----. Mussolini Il Duce. Lo Stato Totalitario, 1936-1940. Turin: Einaudi, 1981.

De Gubernatis, Angelo. . Address. Sandra Puccini. L’Uomo e Gli Uomini: Scritti di Antropologi Italiani Dell'ottocento. Roma, 1893.

-----. Mitologia Zoologica: Le Leggende Degli Animali. Nuova Antologia di Scienze, Lettere e Arti. Firenze: Direzione della nuova antologia, 1872.

de Montesquieu, Charles-Louis de Secondat. Defense de l'Esprit Des Loix. Geneva: Barrillot, 1748.

De Sanctis, Francesco. "Il Mezzogiorno e lo Stato Unitario." L'Italiano, 1868, 22 December 1868.

------. Storia Della Letteratura Italiana. Milan: Rizzoli, 1983 (orig 1870-71).

De Saussure, Ferdinand. Course in General Linguistics. Chicago: Open Court Publishing, 1983.

De Seta, C. "L'Italia Nello Specchio del 'Grand Tour'.” In Storia d'Italia. Annali 5 Il Paesaggio, C. de Seta. Torino: Einaudi, 1982.

De Sismondi Sismonde, J. L. C. Histoire Des Républiques Italiennes Du Moyen Age. Brussels: A. Wahlen, 1839. 
De Stäel, Madame. Corinne, or Italy. S. Raphael. Oxford: Oxford University Press, 1998.

Dei, Marcello. "La Scuola in Italia." In La Scuola in Italia. Bologna: Il Mulino, 2000.

Del Boca, Daniela, and Venturini Alessandra. "Italian Migration." Paper presented at . Mobility and Flexibility of Labor (IZA). Bonn, 2003. Http://ftp.iza.org/dp938.pdf.

Dell, Simon. "The Consumer and the Making of the Exposition Internationale Des Arts Decoratifs et Industriels Modernes, 1907-1925.” Journal of Design History 12, no. 4 (1999): 311-25.

Demolins, Edmonde. À Quoi Tient la Supériorité Des Anglo-Saxons. Paris: Firmin-Didot, 1897.

Di Comite, Luigi. “Aspects of Italian Emigration, 1881-1915." In Migration Across Time and Nations, Ira Glazier and Luigi De Rosa, 148-59. New York: Holmes and Meier, 1986.

Di Non, Secundus. Historia Langobardorum.

Diacono, Paolo. Storia Dei Longobardi. Pordenone: Edizioni Studio Tesi srl., 1990 [787$796 \mathrm{AD}]$.

Diamanti, Ilvo. “L'Italia è la Nostra Famiglia.” Limes 2 (2009).

Dickie, John. "The Notion of Italy." In The Cambridge Companion to Modern Italian Culture, Baranski Zygmunt and Rebecca West. Cambridge: Cambridge University Press, 2001.

Dickinson, Joan Younger. "Aspects of Italian Immigration to Philadelphia." University of Pennsylvania (1966).

Diggins, J. P. Mussolini and Fascism: The View from America. Princeton: Princeton University Press, 1972.

Dillingham, William. Dictionary of Races or Peoples. Reports. Reports of the Immigration Commission. Washington: U.S. Government Printing Office, 1911.

Dinwiddie, Emily Wayland. Housing Conditions in Philadelphia. Philadelphia: Committee of the Octavia Hill Association, 1904.

Di Pietro, Gianni. Da Strumento Ideologico a Disciplina Formativa. I Programmi di Storia Nell'Italia Contemporanea. Milan: Mondadori, 1991.

Duggan, Christopher. The Force of Destiny: History of Italy from 1796 to Today. Boston: 
Houghton Mifflin, 2008.

-----. "Politics in the Era of Depretis and Crispi, 1870-96." In Italy in the Nineteenth Century, John A. Davis, 154-80. Oxford: Oxford University Press, 2006.

Durando, Giacomo. Della Nazionalita`Italiana. Saggio Politico-Militare. Paris: A. Franck, 1846.

Durkheim, Emile. The Division of Labor in Society. New York: The Free Press, 1997.

Epstein, Leonard Arnold. Ethos and Identity: Three Studies in Ethnicity. London: Tavistock Publications, 1978.

Ershkowitz, Herbert. John Wanamaker: Philadelphia Merchant. Cambridge: Signpost Biographies, Da Capo Press, 1999.

Evola, Julius. "Riscoprire la Romanità." Carattere 2 (1942).

Fabi, Lucio. "La Grande Guerra Sul Carso Attraverso i Diari, le Memorie, le Testimonianze Dei Protagonisti." Qualestoria 12 (1986)La Grande Guerra Sul Carso Attraverso i Diari, le Memorie, le Testimonianze Dei Protagonisti.

Falasca-Zamponi, Simonetta. The Aesthetics of Power in Mussolini's Italy. Berkeley: University of California Press, 1997.

Farrar Ware, Caroline. Greenwich Village, 1920-1930 : A Comment On American Civilization In The Post-War Years. Berkeley: University of California Press, 1935.

Fehrenbacher, Don E., and Ward M. McAfee. The Slaveholding Republic: An Account of the United States' Government Relations to Slavery. Oxford: Oxford University Press, 2001.

Fernandez, James. "Peripheral Wisdom.” In Signifying Identities: Anthropological Perspectives on Boundaries and Contested Values, Anthony Cohen, 117-44. London and New York: Routledge, 2000.

Ferrari, G. C. "Osservazioni Sui Feriti Della Nostra Guerra." Rivista di Psicologia 11 (1915): 184-217.

Ferrero, Guglielmo. L'Europa Giovane. Studi e Viaggi Nei Paesi del Nord. Milan: Treves, 1897.

Ferrucci, Caterina Franceschi. Degli Studi Delle Donne. Turin: Pomba, 1853. 
Fichte, Gottlieb Johann. Contribution to the Rectification of the Public's Judgment of the French Revolution, 1793.

------ "The Doctrine of the State." In The Doctrine of the State, 1813.

Flecker, James Elroy. "Mignon.” In The Collected Poems of James Elroy Flecker. In The Collected Poems of James Elroy Flecker, J. C. Squire. New York: Doubleday, Page \& Co., 1916.

Fletcher, Henry P. "Fletcher to State." Correspondence. 811.00F/12. Archives of the Department of State (U.S.D.S.). Washington, 1924.

Foerster, Robert F. The Italian Emigration of Our Times. Cambridge: Harvard University Press, 1919.

Forester, Robert. The Italian Immigration of Our Times. New York: Russell and Russell, 1968.

Fortunato, Giustino. “Dopo la Guerra Sovvertitrice.” In Scritti Politici, F. Barbagallo. Bari: De Donato, 1981 [orig 1921].

Foucault, Michel. The Archaeology of Knowledge. Sheridan Smith. New York: Pantheon, 1972.

------. “The Masked Philosopher.” In The Masked. In Michael Foucault: Politics, Philosophy, Culture. Interviews and Other Writings, 1977-1984, L.D. Kritzman. New York: Routledge, 1988.

Fox, Jon E., and Cynthia Miller-Idriss. "Everyday Nationhood." Enthnicities 8, no. 4 (2008): 536-76.

Franceschi Ferrucci, Caterina. Degli Studi Delle Donne. Turin: Pomba, 1853.

Franchetti, Leopoldo, and Sidney Sonnino. La Sicilia Nel 1876. Firenze: Tipografia di G. Barbera, 1877.

Frank, Dana. "White Working-Class Women and the Race Question." International Labor and Working-Class History 54 (1998): 80-102.

Frohman, Daniel. Encore. New York: Books for Libraries Press, 1937.

Frye Jacobson, Matthew. Roots Too: White Ethnic Revival in Post-Civil Rights America. Cambridge and London: Harvard University Press, 2006.

------. Whiteness of a Different Color: European Immigrants and the Alchemy of Race. 
Cambridge and London: Harvard University Press, 1998.

Fuller, Margaret. These Sad but Glorious Days: Dispatches from Europe, 1846-1850. New Haven: Yale University Press, 1991.

Gabaccia, Donna. From Sicily to Elizabeth Street: Housing and Social Change Among Italian Immigrants, 1880-1930. Albany: State University of New York Press, 1984.

-----. From Sicily to Elizabethan Street: Housing and Social Change Among Italian Immigrants, 1880-1930. New York: Suny Press, 1984.

-----. “Global Geography of 'Little Italy': Italian Neighborhoods in Comparative Perspective." Modern Italy 11, no. 1 (2006): 9-24.

-----. Italy's Many Diasporas. Seattle: University of Washington Press, 2000.

Galasso, Giuseppe. L'Italia s'è Desta, Identità Storica e Unità Nazionale Dal Risorgimento Alla Repubblica. Firenze: Le Monnier, 2002.

Gallenga, Antonio. L'Italia Presente e Futura con Note di Statistica Generale. Florence: Barbera, 1886.

-----. L'Italia Presente e Futura con Note di Statistica Generale. Florence: Barbera, 1886.

Gallenga, Giacinto. Codice Delle Persone Oneste e Civili Ossia Galateo Morale per Ogni Classe di Cittadini. Turin-Naples: Unione Tipografica Editrice, 1871.

Galli della Loggia, Ernesto. L'Identità Italiana. Bologna: Il Mulino, 1998.

Gambino, Richard. Vendetta. The True Story of the Largest Lynching in U.S. History. New York: Doubleday \& Company, Inc., 1977.

Garibaldi, Giuseppe. Autobiography. New York: Fertig, 1971 [orig 1889].

Gellner, Ernest. Nations and Nationalism. Ithaca: Cornell University Press, 1983.

Gemelli, Agostino. Il Nostro Soldato. Saggi di Psicologia Militare. Milan: Treves, 1917.

Gentile, Emilio. La Grande Italia. Ascesa e Declino del Mito Della Nazione Nel Ventesimo Secolo. Milan: Mondadori Editore, 1997.

------. La Grande Italia. Ascesa e Declino del Mito Della Nazione Nel Ventesimo Secolo. Milan: Mondadori, 1997. 
-----. Il Mito Dello Stato Nuovo. Dal Radicalismo Nazionale al Fascismo. Rome-Bari: Laterza, 1999 [orig 1982].

-----. "La Nazione del Fascismo. Alle Origini del Declino Dello Stato Nazionale.” In Nazione e Nazionalità in Italia. Dall'alba del Secolo Ai Nostri Giorni, Giovanni Spadolini. Milan: Angeli, 1994.

-----. Né Stato Né Nazione. Italiani Senza Meta. Bari: Laterza.

------. "La Politica Estera del Partito Fascista. Ideologia e Organizzazioned Dei Fasci Italiani All'estero (1920-1930)." Storia Contemporanea XXVI, no. 6 (1995).

Gentile, Giovanni. “La Colpa Comune.” Il Resto del Carlino (1918).

-----. Guerra e Fede. Bari: Laterza, 1919.

Germinario, Francesco. Razza del Sangue, Razza Dello Spirito. Julius Evola, l'Antisemitismo e Il Nazionalsocialismo, 1930-1943. Turin: Bollati Boringhieri, 2001.

Giardina, Andrea, and André Vauchez. Il Mito di Roma: Da Carlo Magno a Mussolini. Roma-Bari: Laterza, 2000.

Giglioli, Giulio Quirino. Mostra Augustea Della Romanità, 1937-1938. Catalog. Rome: Casa editrice C. Colombo, 1937.

Gillette, Aaron. Racial Theories in Fascist Italy. London and New York: Routledge, 2002.

Gilpin, William. An Essay on Prints. London: R. Blamire, 1792.

Gilroy, Paul. Between Camps: Nations, Cultures and the Allure of Race. London and New York: Routledge, 2004.

Ginzburg, Carlo. The Cheese and the Worms: The Cosmos of a Sixteenth-Century Miller. Baltimore: The Johns Hopkins University Press, 1980.

Gioberti, Vincenzo. Del Primato Morale e Civile Degli Italiani. Brussels: Meline, 1843.

Giusti, Giuseppe. Dizionario Dei Proverbi Italiani, 1852.

Glazer, Nathan, and Daniel P. Moynihan, ed.s. Ethnicity: Theory and Experience. Cambridge: Harvard University Press, 1975. 
------. Beyond the Melting Pot: The Negroes, Puerto Ricans, Jews, Italians and Irish of New York City. Cambridge: The MIT Press, 1963.

Gluckman, Max. Rituals of Rebellion in South-East Africa. The Frazer Lecture Delivered at the University of Glasgow on April 28, 1953. Manchester: University of Manchester Press, 1954.

Gobetti, Pietro. "Elogio Della Ghigliottina.” La Rivoluzione Liberale (1922).

Gobineau, Joseph-Arthur. Essai sur l'Inégalité Des Races Humaines. Paris: Éditions Pierre Belfond, 1967 [1st original ed. 1853-5].

Goethe, Johann Wolfgang von. Wilhelm Meister's Apprenticeship. Blackall, Eric A. Eric A. Blackall. Princeton: Princeton University Press, 1989.

Golab, Caroline. Immigrant Destinations. Philadelphia: Temple University Press, 1977.

Gonzalez, Juan. Harvest of Empire. New York: The Penguin Group, 2000.

Gramsci, Antonio. “Apoliticismo.” In Quaderni del Carcere. Turin: Einaudi, 1952.

------. “Caratteri Italiani.” In Scritti Giovanili, P. Spriano. Turin: Einaudi, 1972 [orig 1914-1918].

------. I Quaderni: Letteratura e Vita Nazionale. I Quaderni Dal Carcere. Roma: Editori Riuniti, 1996.

------. “Quaderni del Carcere,” V. Gerratana. Turin: Einaudi, 1934.

------. Selections from the Prison Notebooks. $<$ Eds $>$ Hoare, Q., Nowell Smith, G. New York: International Publishers, 1995.

------. “La Settimana Politica.” L'Ordine Nuovo (1919).

------. “Lo Stato Operaio.” L'Ordine Nuovo, 1921-1922 (1921).

Grenier, Guillermo, and Stepick Alex. Miami Now! Immigration, Ethnicity, and Social Change. Gainesville: University Press of Florida, 1992.

Grimm, Jacob and Wilhelm. More Tales from Grimm. Wanda Gâag. Minneapolis: University of Minnesota Press, 2006.

Grosby, Steven. Nationalism: A Very Short Introduction. Oxford: Oxford University Press, 2005. 
Guglielminetti, Enrico. "Prefisso Paese: Re-. Alla Ricerca Dell'Italianità." Spaziofilosofico 2 (2011): 137-47.

Guglielmo, Thomas A. White on Arrival: Italians, Race, Color, and Power in Chicago, 1890-1945. New York: Oxford University Press, 2003.

Gupta, Akhil, and James Ferguson. "Beyond 'Culture': Space, Identity, and the Politics of Difference." Cultural Anthropology 7, no. 1 (1992): 6-23.

Habermas, Jürgen. The Structural Transformation of the Public Sphere. Thomas Burger and Frederick Lawrence. Cambridge: MIT Press Massachusetts Institute of Technology, 1991.

Halbwachs, Maurice. On Collective Memory. Chicago and London: The University of Chicago Press, 1992.

Hall, Stuart. "The Question of Cultural Identity." In Modernity and Its Futures. In Modernity and Its Futures, Stuart Hall, David Held, and Tony McGrew, 273-426. Cambridge: Polity Press, 1992.

Haller, Hermann. "Linguistic Interference in the Language of 'Il Progresso ItaloAmericano'..'Italian Americana 5, no. 1 (1979): 55-67.

Hamilton Weigall, Theyre. Boom in Paradise. New York: Alfred H. King, 1932.

Handlin, Oscar. The Uprooted. Boston: Little Brown and Co., 1973.

Hanlon, G. The Twilight of a Military Tradition: Italian Aristocrats and European Conflicts, 1560-1800. New York: Holmes and Meier, 1998.

Harney, Robert F. "Italophobia: English Speaking Malady.” Studi Emigrazione 22, no. 77 (1985): 6-43.

Heap, William A. The Story of Ellis Island. New Jersey: Prentice Hall, 1959.

Hegel, Georg Wilhelm Friedrich. Lectures on the Philosophy of History. London: George Bell and Sons, 1902 [first ed. 1837].

Hentschell, Roze. "Treasonous Textiles: Foreign Cloth and the Construction of Englishness." Journal of Medieval and Early Modern Studies 32, no. 3 (2002): 543-70.

Herder, Gottfried Johann. Treatise on the Origin of Language. Cambridge: Cambridge University Press, 2002 [1772 first edition]. 
Hershberg, Theodore, and et al. "A Tale of Three Cities: Blacks, Immigrants, and Opportunity in Philadelphia, 1850-1880, 1930, 1970.” In Philadelphia: Work, Space, Family, and Group Experience in the Nineteenth Century, Essays Toward and Interdisciplinary History of the City, ed. New York: Oxford University Press, 1981.

Higham, John. Strangers in the Land: Patterns of American Nativism 1860-1925. New York: Atheneum, 1966.

Ho Tai, Hue Tam. "Remembered Realms: Pierre Nora and French National Memory." The American Historical Review 106, no. 3 (2001): 906-22.

Hobsbawm, Eric J. Nations and Nationalism Since 1780: Program, Myth, Reality. Cambridge, New York: Cambridge University Press, 1990.

Hood, Ralph W., and William Paul Williamson. Them That Believe: The Power and Meaning of the Christian Serpent-Handling Tradition. Berkley and Los Angeles: University of California Press.

Horn, D. G. Social Bodies: Science, Reproduction, and Italian Modernity. Princeton: Princeton University Press, 1994.

Hughes, Robert. American Visions: The Epic History of Art in America. London: The Harvill Press, 1998.

Huxley, Thomas Henry. "On the Geographical Distribution of the Chief Modifications of Mankind." Journal of the Ethnological Society of London III (1870).

Imperatori, Ugo E. Dizionario di Italiani All'estero: Dal XIII Secolo Sino a Oggi. Genoa: L'Emigrante, 1956.

Isaacs, Harold R. "Basic Group Identity: The Idols of the Tribe.” In Ethnicity: Theory and Experience, ed.s Daniel P. Moynihan, by Nathan Glazer. Cambridge: Harvard University Press, 1975.

Isneghi, Mario. "Gli Italiani in Guerra. Conflitti, Identità, Memorie Dal Risorgimento Ai Nostri Giorni." In Gli Italiani in Guerra. Conflitti, Identità, Memorie Dal Risorgimento Ai Nostri Giorni. Torino: Utet, 2009.

Jenkins, Richard. Rethinking Ethnicity. Thousand Oaks, CA: Sage, 1997.

------. Rethinking Ethnicity. Thousand Oaks: Sage, 1997.

Jones, Michael Owen. "Food Choice, Symbolism, and Identity: Bread-and-Butter Issures for Folkloristics and Nutrition Studies." The Journal of American Folklore 120, 
no. 476 (2005): 129-77.

Juliani, Richard N. Building Little Italy: Philadelphia's Italians Before Mass Migration. Philadelphia: Penn State Press, 1998.

-----. The Social Organization of Immigration: The Italians in Philadelphia. New York: Arno Press, 1980.

Kant, Immanuel. Critique of Pure Reason. London: Henry G. Bohn, 1855 [1781 first edition].

Kapferer, Bruce. Strategy and Transaction in an African Factory: African Workers and Indian Management in a Zambian Town. Manchester: The University of Manchester Press, 1972.

Katz, Marco. "Not India, in Which Alejo Carpentier and Zora Neale Hurston Finally Discover America." Bibliothèque et Archives Canada Direction du Partrimoine de l'édition (2011): 1-344. Edmonton: University of Alberta.

Kessner, Thomas. The Golden Door: Italian and Jewish Immigrant Mobility, 1880-1915. New York: Oxford University Press, 1977.

King, Bolton, and Thomas Okey. Italy Today. New York: Charles Scribner's Sons, 1910.

King, Edward. “The Great South.” Scribner's Monthly IX, no. November, 1874 (1874).

Kingston, Charles. Royal Romances and Tragedies. New York: Brentano's, 1921.

Kirkpatrick, Sale. Christopher Columbus and the Conquest of Paradise. London: Tauris Parke Paperbacks, 2006.

Kleinberg, Howard. “Miami Beach.” In Miami's Historic Neighborhoods. A History of Community, Becky Roper Matkov, 41-7. San Antonio: Historical Publishing Network.

Kolchin, Peter. "Whiteness Studies: The New History of Race in America." Journal of American History 81 (2002): 154-73.

La Gumina, Salvatore. The Immigrant Speaks. New York: The Center for Migration Studies, 1981.

Laffi, Umberto. Studi di Storia Romana e di Diritto. Roma: Edizioni di Storia e Letteratura, 2001.

LaGumina, Salvatore J. "Italian Americans Respond to the Messina Earthquake 
Disaster." In Italian Americans: Bridges to Italy, Bonds to America, ed.s Luciano J. Iorizzo and Ernest Rossi, E., 65-83. New York: Teneo Press, 2010.

Lakoff, George. Women, Fire, and Dangerous Things. Chicago: Chicago University Press, 1987.

Landes, Joan B. Visualizing the Nation. Ithaca, NY: Cornell University Press, 2003.

Latimer Wormeley, Elizabeth. Italy in the Nineteenth Century. Chicago: McClurg and Co., 1903 [3rd ed.].

Le Bon, Gustave. Lois Psychologiques de l'Evolution Des Peuples. Paris: Alcan, 1894.

-----. The Psychology of Socialism. London: T. Fisher, 1909.

Le Goff, Jacques. History and Memory. New York: Columbia University Press, 1992.

------. “L'Italia Fuori d'Italia.” In L'Italia Fuori d'Italia. Vol. II, L'Italia nello specchio del Medioevo of L'Italia Nello Specchio del Medioevo, Ruggiero Romano and Corrado Vivanti. Storia d'Italia. Torino: Einaudi, 1974.

Leach, Edmund. Culture and Communication: The Logic by Which Symbols Are Connected. Cambridge: Cambridge University Press, 1976.

Leopardi, Giacomo. Canti. $<$ Eds $>$ Gallo, N., Garboli, C. Turin: Einaudi, 1993.

------. Discorso Sopra lo Stato Presente Dei Costumi Degli Italiani. Venice: Marsilio Editore, 1989.

Lessona, Michele. Volere è Potere, 1868.

------. Volere è Potere. Firenze: G. Barbera, Editore, 1872.

Levi, Carlo. “Seconda Lettera Dall'Italia.” In Quaderni di Giustizia e Libertà, 1932.

Lezama Lima, José. Paradise. Trans. Gregory Rabassa. Normal, Illinois: Dalkey Archive Press, 2000 (1st ed. 1968).

Libertini, Giacinto. Persistenza di Luoghi e Toponimi Nelle Terre Delle Antiche Città di Atella e Acerrae. Frattamaggiore, Napoli: Istituto di Studi Atellani, 1999.

Lieberson, Stanley, and Mary C. Walters. From Many Strands. New York: Russel Sage Foundation, 1988.

Lima, Lezama José. Selections. $<$ Ed. $>$ Livon-Grosman, Ernesto. Berkley and California: 
University of California Berkley, 2005.

Lipset, Seymour Martin, and Earl Raab. The Politics of Unreason: Right-Wing Extremism in America, 1790-1970. New York: Harper\&Row, 1970.

Lipsitz, George. "The Possessive Investment in Whiteness: Racialized Social Democracy and the 'White' Problem in American Studies." American Quarterly 47 (1997): 369-427.

Lyttelton, Adrian. Liberal and Fascist Italy. Oxford: Oxford University Press, 2002.

Livi-Bacci, Massimo. L'Immigrazione e l'Assimilazione Degli Italiani Negli Stati Uniti. Milan: A. Giuffrè, 1961.

Lograsso, Angeline H. "Piero Maroncelli in Philadelphia." Romanic Review 24, no. 4 (1933): 323-9.

Lombroso, Cesare. "Sull'antitalianismo Degli Italiani." Nuova Antologia 90 (1901): 31923.

Lombroso, Paola, and Mario Carrara. Nella Penombra Della Civiltà. Inchiesta Sul Pensiero del Popolo. Torino: Fratelli Bocca, 1906.

Lord, Eliot, John D. Trenor, and Samuel J. Barrows. The Italian in America. New York: B. F. Buck \& Co., 1905.

Lord, Eliot, John J. D. Trenor, and Samuel June Barrows. The Italian in America. New York: B.F. Buck and Company, 1905.

Loria, Lamberto. "L'Etnografia Strumento di Politica Interna e Coloniale.” Lares 1, no. 1 (1912): 73-39.

Louai, El Habib. "Retracing the Concept of the Subaltern from Gramsci to Spivak: Historical Developments and New Applications." African Journal of History and Culture 4, no. 1 (2012): 4-8.

Lozzi, Carlo. Dell'ozio in Italia. Turin: Unione Tipografico-editrice, 1870-1871.

-----. Dell'ozio in Italia. Turin and Naples: Unione Tipografico-Editrice, 1871.

Lubrano, Pasquale. Esiste Un'arte Moderna in Italia? Milano: Libreria Milanese, 1912.

Luconi, Stefano. "The Changing Meaning of Ethnic Identity Among Italian Americans in Philadelphia During the Inter-War Years." Pennsylvania History 63, no. 4 (1996). 
-----. La "Diplomazia Parallela": Il Regime Fascista e la Mobilitazine Politica Degli Italo-Americani. Milan: Agnelli, 2000.

------. From Paesani to White Ethnics: The Italian Experience in Philadelphia. Albany: State University of New York Press, 2001.

Maccari, Mino. "Squadrismo. Battagliero Fascista.” Il Selvaggio (1924).

McCormick O'Hare, Anne. "Italy is Hearing the Master's Voice." The New York Times Sunday Magazine (1921).

Mack Smith, Denis. Cavour and Garibaldi. Cambridge: Cambridge University Press, 1954.

-----. I Savoia, Re d'Italia. Milan: BUR Rizzoli, 1990.

Maher, James T. Twilight of Splendor: Chronicles of the Age of American Palaces. Boston: Little, Brown, 1975.

Mahler, Sarah. "Culture as Comfort.” Manuscript accepted for publication. Miami, 2011.

Majakovskij, Vladimir. My Discovery of America. 1st ed. 1926. London: Hesperus Press, 2005.

Malinowski, Bronislaw. Argonauts of the Western Pacific. New York: Dutton, 1922.

Mallozzi, Vincent M. "In Little Italy, a Former Bank Will Now Hold Italian Immigrants' Memories." The New York Times, 2008, 8 September 2008.

Malpezzi, Frances M., and William M. Clements. Italian American Folklore. Little Rock: Augustus House, 1992.

Maltese, Corrado. "Il Momento Unitario Della Pittura Italiana Dell'Ottocento." Bollettino d'Arte del Ministero Della Pubblica Istruzione 1 (1954).

Mameli, Goffredo. Anthem. Lyrics. Genoa, 1847.

Mangione, Jerry. America is Also Italian. New York: G. Putnam and Sons, 1969.

Marescotti, Luigi Aldrovandi. Note Dell'emigrazione Italiana in Pennsylvania. Bollettino Dell'emigrazione n. 3, 1911.

Marinetti, Boccioni, Carrà. “Programma Politico Futurista.” Lacerba (1913).

Marinetti, Filippo Tommaso. “Manifesto del Futurismo.” Le Figaro, 20 febbario, 1909 
1909.

Marraro, Howard R. "Italo-Americans in Pennsylavania in the Eighteenth Century." Pennsylvania History 7, no. 3 (1940): 159-66.

Marselli, Nicola. Gl'Italiani del Mezzogiorno. Rome: Sommaruga, 1884.

Marx, Karl, and Frederick Engels. Selected Works. London: Lawrence and Wishart, 1951.

Marx, Roger. "De l'Art Social e de la Necessité d'en Assurer le Progrès par une Exposition." Idées Modernes (1909), 47.

Mayer, Gordon E. “An Italian House at Miami, Florida.” American Architect 115 (1919): 805-9.

Mazzini, Giuseppe. “D’Alcune Cause Che Impedirono Finora lo Sviluppo Della Libertà in Italia. Articolo 2.” In Interessi e Principii (Orig. La Giovine Italia, 1832). Milan: Bompiani, 1944.

------. “I Collaboratori Della Giovine Italia Ai Loro Concittadini.” In Scrittti Politici Editi e Inediti. Imola: Galeati, 1907-43.

------. “La Questione Morale.” Il Dovere, 1866, 9 March 1866.

Mazzocca, F. “L'Iconografia Della Patria Tra 1'Età Delle Riforme e 1'Unità.” In Immagini Della Nazione Dell'Italia del Risorgimento, 89-111. Rome: Carocci, 2002.

Mazzoleni, Angelo. Il Carattere Nella Vita Italiana. Milano: Galli e Omodei, EditoriLibrai, 1878.

-----. Il Popolo Italiano. Studi Politici. Milan: Vallardi, 1873.

Mitchell, Clyde J. The Yao Village: A Study in the Social Structure of a Nyasaland Tribe. Manchester: The University of Manchester Press, 1956.

Mohl, Raymond, and George Pozzetta. From Migration to Multiculturalism: A History of Florida Immigration. The new history of Florida. Michael Gannon. Gainesville: University Press of Florida, 1996.

Mohl, Raymond A. "Florida's Changing Demography: Population Growth, Urbanization, and Latinization." Environmental and Urban Issues 17 (1990): 22-30.

Montessori, Maria. The Secret of Childhood. Orient Longman, 1978. 
Monti, Augusto. "Attivo e Passivo Sulla Burocrazia." La Rivoluzione Liberale (1922).

Moore Parks, Arva. "The Daddy of Miami." In Memoirs and the History of Miami, by John Sewell. Miami: Arva Parks \& Co., 1987.

-----. “Miami: The Magic City.” In Miami: The Magic City. Miami: Centennial Press, 1991.

Morandi, Rodolfo. Storia Della Grande Industria in Italia. Turin: Einaudi, 1966.

Morcillo, Aurora. “The Orient Within. Women 'in-Between' Under Francoism.” In Women in the Middle East and North Africa: Agents of Change, Fatima Sadiqi and Moha Ennaji, 259-70. New York: Routledge, 2011.

-----. The Seduction of Modern Spain: The Female Body and the Francoist Body Politic. Lewisburg: Bucknell University, 2010.

-----. True Catholic Womanhood: Gender Ideology in Franco's Spain. DeKalb: Northern Illinois University Press, 2000.

Moretti, Enrico. "Social Networks and Migrations: Italy 1876-1913." International Migration Review 33, no. 127 (1999): 640-57.

Mormino, Gary Ross. Immigrants on the Hill: Italian Americans in St. Louis, 1882-1982. Urbana: University of Illinois, 1986.

----. Italians in Florida. New York: Bordighera Press, 2008.

Mormino, Gary Ross, and George E. Pozzetta. The Immigrant World of Ybor City: Italians and Their Latin Neighbors in Tampa, 1885-1985. Urbana: University of Illinois Press, 1987.

Mormino, Gary Ross, and Raymond Arsenault. Land of Sunshine, State of Dreams: A Social History of Modern Florida. Gainesville: University Press of Florida, 2008.

Morrison, Joan, and Charlotte Fox Zabusky. The Immigration Experience in the Words of Those Who Lived It. New York: E. P. Dutton, 1980.

Morselli, Enrico, and Sante De Sanctis. Biografia di un Bandito: Giuseppe Musolino di Fronte Alla Psichiatria Ed Alla Sociologia. Milano: Fratelli Treves, Editori, 1903.

Mosse, Leonard G. The Image of Man: The Creation of Modern Masculinity. New York and Oxford: Oxford University Press, 1996. 
------. Nationalism and Sexuality: Middle-Class Morality and Sexual Norms in Modern Europe. Madison: University of Wisconsin Press, 1985.

------. The Nationalization of the Masses: Political Symbolism and Mass Movements in Germany from the Napoleonic Wars Through the Third Reich. Ithaca and London: Cornell University Press, 1975.

Mosso, Angelo. Vita Moderna Degli Italiani. Milan: Treves, 1906.

-----. Vita Moderna Degli Italiani. Milan: Treves, 1906.

Mowrer, Edgar A. Immortal Italy. New York: Appleton, 1922.

Mozzoni, Anna Maria. La Liberazione Della Donna. Milano: Gabriele Mazzotta Editore, 1975 [orig. 1864].

Muir, Helen. Miami, U.S.A. Gainesville: University Press of Florida, 1953.

Murray, Robert K. Red Scare: A Study of National Hysteria, 1919-1920. St. Paul: University of Minnesota Press, 1955.

Musiedlak, Didier. "Construction Politique et Identité Nationale." In L'Italie, une Nation en Suspens, Ilvo Diamanti, Alain Dieckhoff, Marc Lazar, and Didier Musiedlak. Bruxelles: Editions Complexe, 1995.

Musmanno, Michael. The Italians in America. New York: Doubleday and Co., 1965.

Mussolini, Benito. "Epopea Garbaldina." In Epopea Garibaldina. Vol. 25 of Il Popolo d'Italia, Susmel E. and Susmel D. Il Popolo d'Italia. Florence: La Fenice, 1932.

-----. Opera Omnia. Opera Omnia. Florence: La Fenice, 1951-78.

-----. Opera Omnia. Opera Omnia. Florence: La Fenice, 1951-78.

-----. Opera Omnia. Opera Omnia. Florence: La Fenice, 1951-78.

-----. Opera Omnia. Opera Omnia. Florence: La Fenice, 1951-78.

Nazzaro, Pellegrino. Fascist and Anti-Fascist Propaganda in America: The Dispatches of Italian Ambassador Gelasio Caetani. New York: Library of Congress Cataloging-in-Publication Data, 2008.

Nebbia, Ugo. "L'Italia All'esposizione Internazionale di Parigi di Arti Decorative e Industriali Moderne.” Emporium LXVII, no. 367 (1925). 
$\mathrm{Ng}$, Franklin. "The Soujourner.” In The History and Immigration of Asian Americans. New York: Taylor \& Francis, 1998.

Niceforo, Alfredo. Italiani del Nord e Italiani del Sud. Turin: Bocca, 1901.

------. L'Italia Barbara e Contemporanea. Milano e Palermo: Remo Sandron Editore, 1898.

Nichter, Mark. Anthropological Approaches to the Study of Ethnomedicine. Amsterdam: OPA Gordon and Breach Science Publishers, 1992.

Nigra, Costantino. Canzoni del Piemonte: Donna Lombarda. Rivista Contemporanea. Turin: Tipografia economica diretta da Barera, 1888.

Nolan, David. Fifty Feet in Paradise: The Booming of Florida. San Diego: Harcourt Brace Jovanocich, 1984.

Nora, Pierre. "Between Memory and History: Les Lieux de Mémoire." Representations 26, no. Special issue (1989).

-----. Conflicts and Divisions. Realms of Memory. New York: Columbia University Press, 1996.

------. Traditions. Realms of Memory. New York: Columbia University Press, 1996.

Null, Gary, and Carl Stone. The Italian-Americans. Harrisburg: Stagpole, 1976.

O'Connor, M. The Romance of Italy and the English Political Imagination. New York: St. Martin's Press, 1998.

O'Hare, Anne. "Gender and International History: Public and Private in Anne O'Hare McCormick's Journalism." In Public and Private in American History, G. et al. Baritono. Turin: Otto, 2003 [orig 1923].

Occhini, P. L. “Né Fanciulli Né Semidei.” Il Regno (1903).

Orsi, Robert A. The Madonna of 115th Street: Faith and Community in Italian Harlem, 1880-1950. New Haven: Yale University Press, 2010.

Ozkirimli, Umut. Theories of Nationalism. New York: St. Martin's Press, 2000.

Özkimirli, Umut. "The Nation as an Artichoke? A Critique of Ethnosymbolist Interpretations of Nationalism." Nations and Nationalism 9, no. 3 (2003): 339-55.

P. C. Yorick. Viaggio Attraverso l'Esposizione Italiana del 1861. Firenze, 1861. 
Paine, Robert. "Aboriginality, Authenticity and the Settler World.” In Aboriginality, Authenticity and the Settler World. In Signifying Identities: Anthropological Perspectives on Boundaries and Contested Values, Anthony Cohen, 77-116. London and New York: Routledge, 2000.

Palmer, Gladys. Survey for the Works Progress Administration Operative Plasterers' and Cement Masons’ International Union. Local \# 8. Papers, 1936.

Panizza, Letizia, and Sharon Wood, eds. A History of Women's Writing in Italy. Cambridge: Cambridge University Press, 2000.

Papini, Giovanni. "Ritratto del Carducci." La Voce (1909).

Papini, Roberto. “Le Arti a Parigi Nel 1925. Primo: L'Architettura.” Architettura e Arti Decorative V, no. V (1926): 201-33.

Park, Robert E. The Immigrant Press and Its Control. New York and London: Harper and Brothers Publishers, 1922.

Parrish Reid, Allan. Official Directory of the City of Miami, Florida, Including General Information Concerning Churches, Lodges, Societies. City Directory, 1904-11.

------. Official Directory of the City of Miami, Florida, Including General Information Concerning Churches, Lodges, Societies. City Directory. Miami.

Passerini, Luigi. Mussolini Immaginario. Storia di una Biografia, 1915-1939. RomeBari: Laterza, 1991.

Patriarca, Silvana. "Indolence and Regeneration: Tropes and Tensions of Risorgimento Patriotism." The American Historical Review 110, no. 2 (2005): 380-408.

------. Italian Vices: Nation and Character from the Risorgimento to the Republic. Cambridge: Cambridge University Press, 2010.

Pavoni, Rosanna. Reviving the Renaissance: The Use and Abuse of the Past in Nineteenth-Century Italian Art and Decoration. Cambridge: Cambridge University Press, 1997.

Penka, Karl. Origins of the Aryan, 1883.

Peters, Thelma. Lemon City: Pioneering on Biscayne Bay, 1850-1925. Miami: Banyan Books, Inc.

Picone Petrus, Mariantonietta. Le Grandi Esposizioni in Italia 1861-1911. Napoli: 
Liguori, 1988.

Picone Petrusa, Mariantonietta. "The Italian Neo-Renaissance at Exhibitons During the Later Nineteenth Century." In Reviving the Renaissance. Cambridge: Cambridge University Press, 1997.

Pieterse, Jan Nederveen. Ethnicities and Global Multiculture: Pants for an Octopus. Plymouth: Rowman \& Littlefield Publishers, Inc, 2007.

-----. Ethnicities and Global Multiculture: Pants for an Octopus. Lanham: Rowman\&Littlefield Publishers, Inc., 2007.

Pisani, Mario. L'Onta di Parigi: Il Padiglione Italiano di Armando Brasini All'esposizione di Parigi del 1925. Melfi: Libria, 1996.

Pitkin, H. F. Fortune is a Woman: Gender and Politics in the Thought of Niccolo Machiavelli. Chicago and London: University of Chicago Press, 1984.

Poesche, Theodor. The Aryans: A Contribution to Historical Anthropology, 1878.

Porciani, Ilaria. "Il Plutarco Femminile." In L'Educazione Delle Donne. Scuole e Modelli di Vita Femminile Nell'Italia Dell'Ottocento, S. Soldani, 297-317. Milan: Angeli, 1989.

Portes, Alejandro, and Stepick Alex. City on the Edge: The Transformation of Miami. Berkeley: University of California Press, 1993.

Pozzetta, George E. The Italians of New York City, 1890-1914. Chapel Hill: University of North Carolina, 1971.

Prezzolini, Giuseppe. America in Pantofole. Ragguagli Intorno la Trasformazione Degli Stati Uniti Dopo le Guerre Mondiali. Firenze: Vallecchi Editore, 1950.

------. Benito Mussolini. Giuseppe Prezzolini e La Voce. Emilio Gentile. Florence: Sansoni, 1976 [orig 1924].

------. Codice Della Vita Italiana. Rome: Biblioteca del Vascello, 1993 [orig 1918].

-----. Come Gli Americani Scoprirono l'Italia, 1750-1850. Milano: Treves, 1933.

------. “Dopo un Anno.” La Voce (1912).

-----. “Le Due Italie.” La Voce (1904).

-----. Italia 1912. Dieci Anni di Vita Intellettuale. <Ed> Simonetti, C. M., 1912. 
-----. “La Nostra Promessa.” La Voce, 1908, 27 December 1908.

-----. "Ventiquattr'ore in Italia." La Voce (1910).

Protonotari, F. La Nazione, no. 199; 226; 242; 248; 250; 256; 258 (1861).

Protonotari, Francesco. "Esposizione Italiana Tenuta in Firenze." In Relazione Generale Sull'Esposizione Italiana Tenuta in Firenze Nel 1861, vol. 3. Relazione generale. Firenze: Barbera, 1864-1867.

Pullé, Francesco. "Profilo Antropologico Dell'Italia." Archivio per l'Antropologia e la Etnologia (1898), 19-163 Archivio per l'Antropologia e la Etnologia, Paolo Mantegazza.

Quatrefages, Jean Louis Armand. Histoire Générale Des Races Humaines. Paris: A. Hennuyer, 1886-1889.

Quondam, Amedeo. "Il Barocco e la Letteratura: Genealogie del Mito Della Decadenza Italiana." In I Capricci di Proteo. Percorsi e Linguaggi del Barocco. Rome: Salerno, 2002.

Ragionieri, E. L'Italia Giudicata 1861-1945 Ovvero la Storia Degli Italiani Scritta Dagli Altri.Bari: Laterza, 1969.

Rameri, Luigi. L'Educazione del Popolo Italiano Alla Vita Morale e Civile. Milan: Zanetti, 1864.

Reale, Antonio. Nazione e Famiglia. Studio Intorno al Carattere. Milan: Tip. Pirola, 1878.

Renan, Ernest. "What is a Nation?" In Becoming National: A Reader, Becoming national. New York and Oxford: Oxford University Press, 1996.

Ressa, Giuseppe. Il Sud e l'Unità d'Italia. Monograph. Napoli e Palermo: Centro Culturale e di Studi Storici, 2009.

Rhodes, Jim. “Ten Rules for Good Advertising.” Blog entry. Jim Rhodes. Norfolk, 2012.

Riall, Lucia. Garibaldi: Invention of a Hero. New Haven: Yale University Press, 2007.

Riall, Lucy. "Garibaldi and the South." In Italy in the Nineteenth Century, John A. Davis. Oxford: Oxford University Press, 2006.

Ribuffo, Leo P. The Old Christian Right: The Protestant Hard Right from the Great 
Depression to the Cold War. Philadelphia: Temple University Press, 1983.

Richard, E. "Genèse d'une Exposition.” In Catalogue Général Officiel. Exposition Internationale Des Arts Décoratifs et Industriels Modernes. Paris: De Vangirard, 1925.

Ricoeur, Paul. Memory, History, Forgetting. Chicago and London: The University of Chicago Press, 2006.

Riis, Jacob. How the Other Half Lives: Studies Among the Tenements of New York. New York: Hill and Wang, 1957.

Roediger, David R. Working Toward Whiteness: How America's Immigrants Became White, the Strange Journey from Ellis Island to the Suburbs. Cambridge: Basic Books, 2006.

Rojo, Benitéz Antonio. "Alejo Carpentier: Between Here and Over There." Caribbean Studies 27, no. 3/4 (1994): 183-95.

Ross Alsworth, Edward. The Old World in the New: The Significance of Past and Present Immigration to the American People. New York: The Century Co., 1914.

Rosselli, Carlo. Socialismo Liberale. Rome, Florence, Milan: Edizioni U, 1945.

Rousey, Dennis C. "Cops and Guns: Police Use of Deadly Force in Nineteenth-Century New Orleans." The American Journal of Legal History 28, no. 1 (1984): 41-66.

Rousseau, Jean Jacques. The Social Contract or the Principles of Political Rights. New York and London: G. P. Putnam's Sons, 1893.

Rubini, Luisa. "Della Traducibilità del Folklore: Figure e Aspetti Della Mediazione Culturale Tra Italia e Germania Nell'ottocento." In Romantici in Europa: Tradizioni Popolari e Letteratura, Giorgio Cusatelli, 51-7. Brescia: Grafo S.p.A., 1996.

Russo, M., and et al., eds. Nationalisms and Sexualities. London: Routledge, 1992.

Rybczynski, Witold, and Olin Laurie. Vizcaya: An American Villa and Its Makers. Philadelphia: University of Pennsylvania Press, 2007.

Sabbatucci, Giovanni. Il Trasformismo Come Sistema. Saggio Sulla Storia Politica Dell'Italia Unita. Rome-Bari: Laterza, 2003.

Said, Edward. Orientalism. New York: Pantheon Books, 1978. 
Salamini, Leonardo. "Towards a Sociology of Intellectuals: A Structural Analysis of Gramsci's Marxist Theory." In Antonio Gramsci: Critical Assessments of Leading Political Philosophers, James Martin. New York: Taylor \& Francis, 2002.

Salustri, Carlo Alberto. Acqua e Vino. Roma: Arnoldo Mondadori (Tip. Operaia Romana), 1945.

Salvemini, Gaetano. "Gl'italiani Come Veramente Sono: Studio di Psicologia Europea." In L'Italia Vista Dall'America, Tagliacozzo. E. Milan: Feltrinelli, 1942.

------. Italian Fascist Activities in the United States. New York: Center for Migration Studies, 1977.

-----. "Lezioni da Harvard. L'Italia Dal 1919 al 1929.” In Scritti Sul Fascismo, R. Vivarelli. Milan: Feltrinelli, 1963.

Sapegno, Natalino. “Il Piemonte e le Province.” La Rivoluzione Liberale (1922).

Sarfatti, Marina, and Teofilo Rossi. "Il Padiglione." In Esposizione Internazionale d'Arti Decorative e Industriali Moderne, 9-60. Roma, 1928.

Saunders, George R. “'Critical Ethnocentrism' and the Ethnology of Ernesto De Martino." American Anthropologist, New Series 95, no. 4 (1993): 875-93.

Saverino, Joan. "Mapping Memories in Stone." In Global Philadelphia: Immigrant Communities Old and New, Ayumi and Osirim Takenaka, Mary Johnson. Philadelphia: Temple University Press, 2010.

Scaglione, E., and B. Chiara, eds. L'Impresa Libica. Italia Vittoriosa. Antologia Delle Piú Belle Pagine. Naples: Bideri, 1917.

Scarlett, Frank, and Marjorie Townley. Arts Décoratifs: A Personal Recollection of the Paris Exhibition. Paris: Academy Editions, 1975.

Schiavo, Giovanni Ermenegildo. The Italians in America Before the Civil War. New York: Italian Historical Society Vigo Press, 1934.

Schnapp, Jeffrey T. "Epic Demonstrations: Fascist Modernity and the 1932 Exhibition of the Fascist Revolution." In Fascism, Aesthetics, and Culture, Richard J. Golsan. Hanover and London: University Press London, 1992.

----- "Program of the National Fascist Party." In A Primer of Italian Fascism. Lincoln and London: University of Nebraska Press, 2000.

Schneider, Jane. "Introduction: The Dynamics of Neo-Orientalism in Italy (1848-1995)." 
In Italy's “Southern Question”: Orientalism in One Country, Jane Schneider. Oxford and New York: Berg, 1998.

Schopenhauer, Arthur. Parerga e Paralipomena. Milan: Adelphi, 1981 [1st orig. edition 1851].

Schwegman, Marjan. Maria Montessori, l'Identità Italiana. Bologna: Soc. Ed. Il Mulino, 1999.

Scranton, Philip. Endless Novelty: Specialty Production and American Industrialization, 1865-195. Princeton: Princeton University Press, 1997.

------. "The Transition from Custom to Ready-to-Wear Clothing in Philadelphia, 18901930." Textile History 25, no. 2 (1994).

Sella, Quintino. "Proposta per Ampliare da Provinciale a Nazionale l'Esposizione Toscana." In Palermo e l'Esposizione Nazionale del 1891-1892. In Proposta per Ampliare da Provinciale a Nazionale l'Esposizione Toscana, in Le Esposizioni Tenute Finora. Keynote address. Special Rept., R. Barbiera. Milano: Treves, 1892.

Serao, Matilde. “Un Invio.” In Un Invio. In Primavera Italica. “, Scaglione, 1911.

Sergi, Giuseppe. Arii e Italici. Attorno All'Italia Preistorica. Turin: Bocca, 1898.

------. La Decadenza Delle Nazioni Latine. Turin: Bocca, 1900.

-----. Origine e Diffusione Della Stirpe Mediterranea. Rome: D. Alighieri, 1895.

------. Per l'Educazione del Carattere. Pagine di Psicologia Sociale e Consigli Direttivi. Turin: Camilla e Bertolino, 1885.

Sewell, John. Memoirs and History of Miami, Florida. Miami: The Franklin Press, Inc., 1933.

Sforza, Carlo. Les Italiens Tels Qu'ils Sont. Montreal: Editons de l'Arbre, 1941.

-----. L'Âme Italienne. Paris: Flammarion, 1934.

Showerman, Grant. Eternal Rome. New Haven: Yale University Press, 1924.

Sighele, Schipio. “Quello Che Abbiamo Compiuto.” Primavera Italica (1911).

Sighele, Scipio. Contro Il Parlamentarismo. Saggio di Psicologia Collettiva. Milan: Treves, 1895. 
Simeone, William E. "Italian Folklore Scholars." The Journal of American Folklore 74, no. 294 (1961): 344-53 Italian Folklore Scholars.

Smiles, Samuel. Il Carattere. Florence: Barbera, 1872.

------. Self-Help with Illustrations of Conduct and Perseverance. London: J. Murray, 1859.

Smith, Adam. An Inquiry Into the Nature and Cause of the Wealth of Nations. London: W. Strahan and T. Cadell, 1776.

Smith, Anthony D. Nationalism. Cambridge: Polity, 2001.

Smith, Victor. Vieilles Chansons Recueillies en Velay et en Forez. Nogent-le-Rotrou: G. Daupeley, 1878.

Snyder, Charles, John W. Downie, and Kalp Lois S. Union County, Pennsylvania: A Celebration of History. Montoursville, PA: Union County Historical Society, 2000.

Spackman, Barbara. Fascist Virilities: Rhetoric, Ideology, and Social Fantasy. Minneapolis and London: University of Minnesota Press, 1996.

Spencer, Herbert. The Principles of Biology. London and Edinburgh: Williams and Norgate, 1864.

Speroni, Charles. "The Development of the Columbus Day Pageant of San Francisco." Western Folklore 7, no. 4 (1948): 325-35.

Spriano, P. Gramsci e Gobetti. Introduzione Alla Vita e Alle Opere. Turin: Einaudi, 1977.

Starr, Kevin. Inventing the Dream: California Through the Progressive Era. Oxford: Oxford University Press, 1985.

Sterba, Christopher M. Good Americans: Italian and Jewish Immigrants During the First World War. New York: Oxford University Press, 2003.

Stewart-Steinberg, Suzanne. The Pinocchio Effect: On Making Italians, 1860-1920. Chicago: The University of Chicago, 2008.

Stoneman Douglad, Marjory. "The Galley. Venice to Miami.” The Miami Herald 11, no. 239 (1921, 22 July 1921): 6 .

Stoneman Douglas, Marjorie. The Everglades: River of Grass. New York: Rinehart\&Company, 1947. 
Stoneman Douglas, Marjory. "The Galley.” The Miami Herald 12, no. 265 (1922, 17 August 1922): 8.

-----. Voice of the River. Sarasota: Pineapple Press Inc., 1990.

Stoner Sackville, Winifred Jr. "The History of the U.S.” In The History of the U.S. In Facts in Jingles, 1919.

Strafforello, Gustavo. La Sapienza del Popolo Spiegata al Popolo Ossia Proverbi di Tutte le Nazioni. Milan: Editori della Biblioteca Utile, 1868.

Sullivan, John. "Manifest Destiny." The United States Magazine and Democratic Review (1845).

Takaki, Ronald. A Larger Memory. Boston: Little Brown and Co., 1998.

Thrower, Norman Joseph William. Maps and Civilization: Cartography in Culture and Society. Chicago: The University of Chicago Press, 1972.

-----. Maps and Civilization: Cartography in Culture and Society. Chicago: The University of Chicago Press, 1972.

Tirado Bramen, Carrie. "The Urban Picturesque and the Spectacle of Americanization." American Quarterly 52, no. 3 (2000): 444-77.

Tobia, B. Una Patria per Gli Italiani. Spazi, Itinerari, Monumenti Nell'Italia Unita (1870-1900). Rome-Bari: Laterza, 1991.

Topa, Michele. Così Finirono i Borboni di Napoli. Napoli: F. Fiorentino, 1959.

-----. I Briganti di Sua Maestà. Napoli: F. Fiorentino, 1967.

Torre, Stefania. "L'Emigrazione in Italia Dal 1871 al 1911 e Il Mezzogiorno." In Nord e Sud a 150 Anni Dall'Unità d'Italia, vol. Numero speciale. Quaderni SVIMEZ. SVIMEZ Associazione per lo sviluppo dell'industria nel Mezzogiorno, 2012.

Toscano, Mario. "Marcello Ricci. Una Testimonianza Sulle Origini del Razzismo Fascista." Storia Contemporanea 27 (1996).

Toschi, Paolo. Fenomenologia del Canto Popolare. Roma: Edizioni dell'Ateneo, 1951.

-----. Guida Allo Studio Delle Tradizioni Popolari. Roma, 1945 [2nd edition].

Triandafyllidou, Anna. Immigrants and National Identity in Europe. London and New 
York: Routledge, 2001.

Trivulzio di Belgiojoso, Cristina. Osservazioni Sul Presente Stato Dell'Italia e Sul Suo Avvenire. Milano: Vallardi, 1868.

Turiello, Pasquale. Governo e Governati in Italia. Saggio. Bologna: Zanichelli, 1882.

-----. Governo e Governati in Italia. Saggio. Bologna: Zanichelli, 1882.

-----. Saggio Sull'educazione Nazionale in Italia. Napoli: Pierro, 1891.

Turner, Victor. The Anthropology of Performance. New York: PAJ Publications, 1986.

-----. The Forest of Symbols: Aspects of Ndembu Ritual. New York: Cornell University Press, 1967.

-----. From Ritual to Theater: The Human Seriousness of Play. New York: PAJ Publications, 1982.

Tuttle, Julia. "Record Group 1.” Incoming Correspondence. Office MS Box 47, Office, 1879-1894. New York: The Rockefeller University, 1886.

Uccello, Antonino. Risorgimento e Società Nei Canti Popolari Siciliani. Catania: Pellicano Libri, 1978.

Uguccioni, Ellen J. “Coral Gables.” In Miami’s Historic Neighborhoods, a History of Community, Becky Matkov Roper, 100-105. San Antonio: Historical Publishing Network, 2000.

Underhill, Ruth M. Child Labor in Italy. Report of the commission for the tubercolosis. American Red Cross in Italy. Rome: Tipografia Nazionale Bertero, 1919.

Vansittart, E. C. "Some Italian Invocations." The Antiquarian XXXVIII, no. JanuaryDecember, 1902 (1902).

Vecoli, Rudolph J. "Contadini in Chicago: A Critique of the Uprooted." Journal of American History, no. 51 (1964).

Venturi. "L'Italia Fuori d'Italia." In L'Italia Fuori d'Italia. In Storia d'Italia. Dal Primo Settecento All’Unità. Turin: Einaudi, 1973.

Venturi, F. "The Enlightenment in Southern Italy." In Italy and the Enlightenment: Studies in a Cosmopolitan Century, S. Wool. London: Longman, 1972.

Verri, Pietro. "Decadenza del Papato, Idea del Governo di Venezia e Degli Italiani in 
Generale.” In Scritti Vari, Giulio Carcano. Firenze: Le Monnier, 1854.

Villa, Horatio L. "Hialeah." In Miami's Historic Neighborhoods: A History of

Community, Miami's historic neighborhoods, 63-5. San Antonio: Historical Publishing Network, 2001.

Villari, Pasquale. "Di Chi è la Colpa? O Sia la Pace e la Guerra." Il Politecnico II, no. 4 (1866).

-----. "I Rimedii." In Le Lettere Meridionali e Altri Scritti Sulla Questione Sociale in Italia, 61-76. Florence: Le Monnier, 1878.

------. Le Lettere Meridionali Ed Altri Scritti Sulla Questione Sociale in Italia. Torino, 1885.

------. Le Prime Lettere Meridionali. Rome, 1920 [prima edizione 1861].

-----. “La Scuola e la Questione Sociale in Italia.” In Nuova Antologia, 197-257, 1872.

Waitz, Georg, ed. Origo Gentis Langobardorum, Scriptores Rerum Langobardicarum et Italicarum Saec. VI-IX. Monumenta Germaniae Historica. Scriptores Rerum Langobardicarum et Italicarum. Hannover: Impensis Bibliopolii Hahniani, 1878.

Weber, Max. "Ethnic Groups." In Economy and Society, Guenther Roth and Klaus Wittich, 385-98. Berkeley: University of California, 1978.

-----. Protestant Ethic and the Spirit of Capitalism. Piero Burresi, 1931.

-----. The Vocation Lectures: Science as a Vocation; Politics as a Vocation. Indianapolis: Hackett Publishing Company, Inc., 2004.

Weibust, Patricia, Gennaro Capobianco, and Sally Innis Gould. The Italians. World Education Project, 1976.

Werbner, Richard. Ritual Passage, Sacred Journey: Process and Organization of Religious Movement. Smithsonian Institution, 1989.

Whyte Foote, William. "Race Conflicts in the North End of Boston." The New England Quarterly 12, no. 4 (1939): 623-42.

Wilbanks, William. Forgotten Heroes: Police Officers Killed in Early Florida, 18401925. Padukah, KY: Turner Publishing Company, 1998.

Wilde, Oscar. Epigrams and Aphorisms. Boston: J.W. Luce, 1905. 
Williams, Brackette F. "A Class Act: Anthropology and the Race to Nation Across Ethnic Terrain.” Annual Review of Anthropology 18 (1989): 401-44.

Wohl, Robert. The Generation of 1914. Cambridge: Harvard University Press, 1979.

Wolfers Nancy, and Paolo. Mazzoni. La Firenze di G. Martelli (1792-1876): L'Architettura Della Citta` Fra Ragione e Storia. Catalogue. Firenze: Parretti, 1980.

Woodhouse, J.R. "Literature.” In Liberal and Fascist Italy, Adrian Lyttelton, 216-32. Oxford: Oxford University Press, 2002.

Yans-McLaughlin, Virginia, and Marjorie Lightman. Ellis Island and the Peopling of America. New York: The New York Press, 1990.

Zanazzo, Gigi. Tradizioni Popolari Romane. Canti Popolari Romani con un Saggio Dei Canti del Lazio. Roma: Arnaldo Forni Editore, 1907.

Zanoni, Enrico. Studio Sui Caratteri Nazionali. Milan: Robecchi, 1883.

Zitara, Nicola. "La Gran Cuccagna Dei Fratelli d'Italia." Due Sicilie 2 (2004).

Zuccarini, Emilio. Il Lavoro Degli Italiani Nella Repubblica Argentina, Dal 1516 al 1910: Studi,Leggende e Ricerche. La Patria degli Italiani, 1910.

DISSERTATIONS

Braden, Susan R. "Florida Resort Architecture: The Hotels of Henry Plant and Henry Flagler." Ph.D. diss. Tallahassee: The Florida State University, 1987. Http://ezproxy.fiu.edu/login?url=http://search.proquest.com/docview/303466376? accountid $=10901$.

Covello, Leonard. "The Social Background of the Italo-American School Child: A Study of the Southern Italian Family Mores and Their Effect on the School Situation in Italy and America." Ph.D. diss. ProQuest Dissertations and Theses (1944), 744. New York: New York University.

Gizzarelli, Ermanno Francis. "An Historical Survey of Italian Folk Song and a Critical Estimate of Modern Research.” Ph.D. diss. New York: Cornell University, 1938. 


\section{SELECTED ON-LINE INTERNET SOURCES}

Ancestry.com

Chronicling America, Historic American Newspapers, Library of Congress

Florida Memory Project

PALMM: Publication of Archival Library and Museum Materials, State Universities of

Florida

University of Florida Digital Collections 


\section{ANTONIETTA DI PIETRO}

1978-1982

2005

2006-2008

2009-

2009-2013

2010-2011

2012-

2012-2013

2013-

2013-
Centro di Alta Specializzazione per la

Decorazione Pittorica, Rome, Italy

B.A., History

Florida International University

Miami, Florida

M.A., History

Florida International University

Miami, Florida

Adjunct of Italian

Florida International University

Miami, Florida

Doctoral Program, History

Florida International University

Miami, Florida

President, Florida Association Teachers of Italian

Miami, Florida

International Baccalaureate Examiner/Italian

M.A., Letteratura e Didattica della Lingua Italiana

Università per Stranieri di Siena

Siena, Italy

ACTFL OPI Certified Tester/Italian

College Board, AP Italian Committee Member

\section{FELLOWSHIP, PUBLICATIONS, AND PRESENTATIONS}

NEH 2004 Fellowship - Summer Institute "The Art of Teaching Italian through Italian Art”, July 2004. Georgetown University, Washington D.C.

Di Pietro, Antonietta (2013). All in One Italian, Wiley Publisher.

College Board, AP Italian, writer for the Annotated Resources in the Online Teacher Community, (2011).

Review of Alexandra Parma Cook and Noble David Cook, The Plague Files: Crisis Management in Sixteenth-Century Seville. Baton Rouge: Louisiana State University Press, 2009. 104-106. ISBN 978-0-8071-3404-07 
Marie de' Medici: Muse or Strategist? In Selected Annual Proceedings of the Florida Conference of Historians, ed. Joseph Patrouch, 29-37. Florida Conference of Historians, 2007.

ACTFL 2013, Orlando, "Teaching Italian through Italian Modern Opera."

ACTFL 2012, Philadelphia, "TBI and the Subjunctive Mood."

E Pluribus: What Is Italian America? Hofstra University, New York, 2012.

Molto lieto, Congiuntivo: Formal Register and Use of the Subjunctive Mode, 2012.

Modern Languages Department, Foreign Languages Conference and Workshops, Florida International University, Miami Florida.

Final Film Project: Cinecittà 'made in' FIU, Contemporary Italian Cinema Conference on new trends in modern and contemporary Italian Cinema, Indiana University, Bloomington, 2012.

American Italian Historical Association, conference Italian American Body Politics: Private Lives and Public Sphere, Tampa, 2011.

University of Pennsylvania, conference From the Unity of Italians to the Unity of Italics, Philadelphia, 2011.

Futuristiche emozioni: l'Italiano e la modernità, Florida International University, 2010.

Florida Conference of Historians, Miami Beach, 2006. "Marie de' Medici: A Muse or a Strategist? How Opera, Painting and Chronicle investigate the Theme of Agency."

"Lingua e cultura", Università di Roma Tor Vergata, Rome, Italy, 2006.

"Italian Studies in the South East", Florida Atlantic University, Boca Raton, FL, 2005.

ACTFL 2004, Chicago, "La lingua italiana attraverso l'arte." 